\title{
THE 1942 JAPANESE GENERAL ELECTION: Political Mobilization in Wartime Japan
}

\author{
by \\ Edward J. Drea
}

International Studies, East Asian Series

Research Publication, Number Eleven

Center for East Asian Studies

The University of Kansas 


\title{
THE 1942 JAPANESE GENERAL ELECTION: Political Mobilization in Wartime Japan
}

\author{
by \\ Edward J. Drea
}

International Studies, East Asian Series

Research Publication, Number Eleven

Center for East Asian Studies

The University OF Kansas 
Copyright 1979

Center for East Asian Studies

The University of Kansas

Library of Congress catalog number 79-18561

All rights reserved

Manufactured in the United States of America

Sole distributors in the USA \& Canada

Paragon Book Gallery, Ltd.

14 East 38th Street

New York, N.Y. 10016 
To MY FATHER

John T. Drea (1900-1977) 


\section{Acknowledgements}

Any value this book may have is due to the kindness and assistance of persons on both sides of the Pacific. Professor Grant Goodman suggested the topic and provided direction throughout. Professors Daniel Bays, Thomas Havens, G. Cameron Hurst, Chae Jin Lee, Henry Snyder, and Theodore Wilson read drafts of various stages and offered criticism and advice. Mr. Eugene Carvalho, director of the East Asian Library of the University of Kansas, secured valuable research materials for my study. Mr. Key K. Kobayashi of the Library of Congress and Mr. John Taylor of the National Archives facilitated my research in Washington.

In Japan Professor Miwa Kimitada supervised this work. Ms. Yamaguchi Miyoko of the National Diet Library deserves thanks for her gracious assistance. Professor Hōra Tomio and Mrs. Inohara Shōko allowed me to study valuable documents at Waseda University. Mr. Maruyama Shinyo of the Japan Foundation arranged most of my interviews, while Mr. Suekuni Masao and Ms. Togawa Yukie assisted me at the Self Defense Headquarters War History Room and the Foreign Ministry Archives respectively. Mr. Ōkubo Genji of the Canadian Embassy was especially helpful. Professors Awaya Kentarō, Ito Takashi, Sodei Rinjirō, and Nakamura Hisashi all unselfishly helped me.

I owe special thanks to a good friend Mr. Ōkura Yũji for all the help he gave me but more for the way he made me feel at home in Tokyo. My wife Kazuko deserves many thanks for her patience and understanding.

Ft. Leavenworth, Kansas

November 1979 


\section{Preface}

"This (candidate recommendation committee) is one form of election interference and may be considered an unconstitutional act leading to the appearance of a Diet hand-picked by the (Tojo) government."1 Ozaki Yukio (1859-1954), the dean of prewar Japanese electoral politics, addressed that stinging assessment of the 1942 Japanese general election to then Prime Minister Tojo Hideki (1884-1948). The American Occupation authorities enthusiastically endorsed Ozaki's interpretation by purging all recommended candidates from official life. The International Military Tribunal for the Far East accepted a similar evaluation and, even today, the 1942 election remains fixed in the popular imagination at the archetypical totalitarian style, rigged election.

There are two reasons the Japanese regard the 1942 general election as an electoral aberration. First, in the absence of political parties, a candidate recommendation committee nominated a slate of candidates for the election. Since approximately $80 \%$ of these so-called recommended candidates ultimately won election, the impression exists that the election was merely a show election with predetermined results. Second, an election in Japan during the Pacific War (1941-1945) seems incongruous, moreso because the personification of Japanese militarism General Tojo Hideki was the prime minister. The assumption is that the successful candidates in this blatantly rigged election formed the basis of General Tojo's so-called wartime dictatorship.

Consequently, both Japanese historians and American historians of Japan ignore the 1942 general election. Yet that election bridges the prewar and postwar eras in Japanese constitutional politics. Four postwar Japanese prime ministers won election in 1942 and candidates active in 1942 still remain in the Diet today. Although the Occupation authorities purged all recommended candidates from official life, those same candidates quickly reestablished their preeminent positions in the Japanese political hierarchy as soon as the Occupation ended in 1952. The 1942 general election was, in retrospect, a transitional election that closed one constitutional era but still affects the present one. 
My purpose in writing this book is not to assign praise or blame to individual Japanese or to specific Japanese political and social institutions. Rather, based on available primary source Japanese language materials, this study will examine the 1942 Japanese general election chronologically in order to place that election in its historical context. A key contention is that the 1942 election does not represent an electoral anomaly but that it does fit well within the context of traditional Japanese elections.

I base the foregoing contention on the following types of materials:

1. Unpublished official documents. These include prewar Home Ministry Police Bureau and Metropolitan Police Board records that are part of the Library of Congress, compiler, Microfilm Reproductions of Selected Archives of the Japanese Army, Navy, and Other Government Agencies, 1868-1945. Additional police archives available as Library of Congress, compiler, Microfilm Japanese Rarities and Microfilm Orien Japan, cabinet records at the Japanese National Archives (Kokuritsu köbun shokan), and classified records of the Imperial Rule Assistance Association and the Imperial Rule Assistance Political Structure Cooperative Council supplement the above documents.

2. Published official documents. These include documents in the Gendaishi shiryō series, thought police reports, Imperial Diet proceedings, contemporary election materials, and publications of various organs connected with the 1942 election campaign.

3. Memoirs of candidates and of persons connected with the election. This material ranges from court diaries to the self serving recollections of defeated candidates.

4. Contemporary newspaper and magazine reports about the election campaign.

5. Interviews with former 1942 candidates, bureaucrats, and election organizers.

I have chosen to omit macrons for well known Japanese names like Tojo Hideki or Tokyo. 


\section{Table of Contents}

AcKNowLEdGEMENTS …................................................................................. $\mathrm{v}$

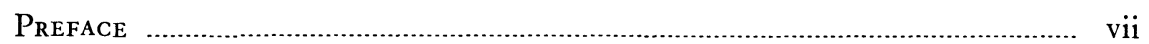

Chapter

1 Politics of Disorder (1940-1941) .................................................. 1

2 Organizing the Wartime Election …........................................... 19

3 The Home Ministry Prepares ....................................................... 45

4 The Candidate Recommendation System and Its Critics ................... 63

5 The 1942 Election Campaign: An Overview .................................... 83

6 Candidates and Campaigning ......................................................... 103

7 The Hollow Victory ........................................................................... 133

Notes

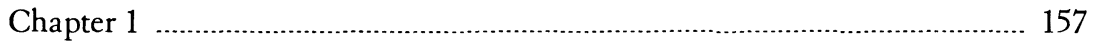

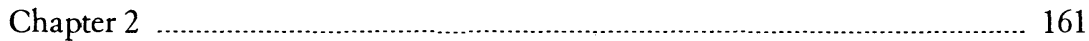

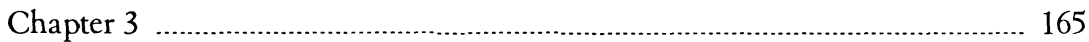

Chapter 4 ........................................................................................... 169

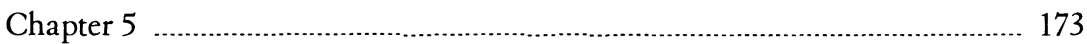

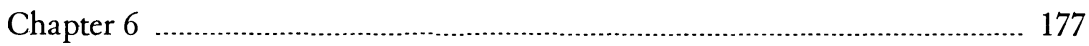

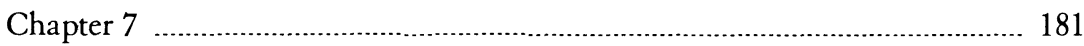

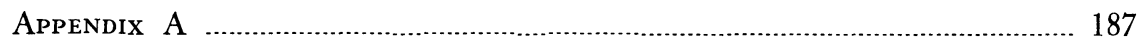

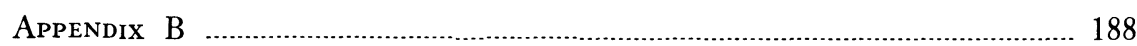

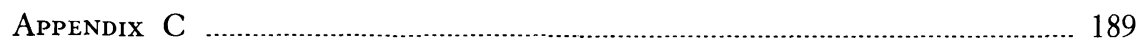

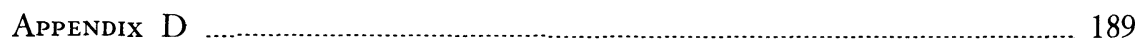

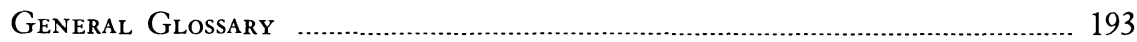

Glossary of Personal Names _..................................................................... 199

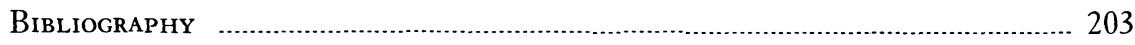

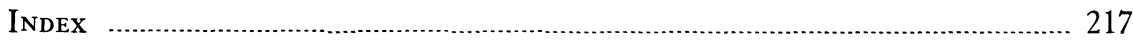





\section{Chapter One \\ Politics of Disorder \\ (1940-1941)}

\section{Introduction: Japanese Elections and Japanese Politicians}

As long lines of Japanese voters formed queues before election polling stations on April 30, 1942, they were the latest participants in a half-century old tradition of popular electoral politics. The Meiji Constitution (1889-1947) guaranteed popular elections and elections became a part of the prewar Japanese political landscape. No one except the most conservative rightist questioned the legitimacy or the role of elections in the political process. Since the first Japanese general election in 1890 , electioneering had become increasingly complex and sophisticated. The government cautiously extended the suffrage and in 1925 granted universal male suffrage to its citizens. These peaks of electoral progress overshadowed valleys of election interference.

The Home Ministry enforced election regulations but it quickly became apparent that police enforcement was susceptible to abuses because home ministers or powerful prefectural governors could order their subordinate police officials to intervene in election campaigns for a particular candidate's advantage. As the most powerful local official, the governor presided over a regional bureaucratic pyramid which rested on the petty bureaucrats and police who handled the day-today administrative workload at the village level. He also depended unofficially on the cooperation of local leaders, the so-called meibo $k a$ (lit. men of high reputation) or yüryokusha (lit. influential men) to implement government policies. These community leaders, mainly landlords but also including local educational, civic, and financial leaders, guided unofficial village relations, acted as buffers between the local bureaucracy and the people, and served as filters for the two way flow of information from village to official and vice-versa. ${ }^{1}$ At election time, a governor might use his connections with the community leaders to gain their support for his candidate. 
Candidates met the recurrent threat of campaign interference individually and collectively. Individually the professional politician developed a strong, dependable area of electoral support, his jiban. He organized his jiban around the community leaders for durability, but the more common jiban organized around a group of community leaders having no fixed attachment to any single politician. The politician's continued success depended on his ability to implement local aspirations to please the local leaders. For their part, the community leaders secured the votes necessary to elect the candidate, so campaigning and campaign oratory were not as crucial as local backing, the direct or indirect support of prefectural officials, and agreements between running mates not to encroach on each other's jiban. ${ }^{2}$ In the 1942 campaign, for instance, veteran Diet incumbents with jiban like Maeda Yonezō (1882-1954) and Hatoyama Ichirō (18831959 ) either campaigned by pamphlets or campaigned for their colleagues, but did not spend much time or energy campaigning in their own jiban. Similarly, Hatoyama and Tagawa Daikichirō (1869-1947), though party colleagues from Tokyo, carefully avoided each other's jiban when campaigning. ${ }^{3}$

Collectively, the professional politician as a member of a political party took special care to obtain his share of pork barrel legislation for his district and jiban. In the early Twentieth Century, the political parties penetrated the bureaucracy, especially the Home Ministry, and developed a spoils system. Election preparations or changes in party cabinets meant wholesale shifts of governors, police directors, and in severely contested prefectures, even changes from the police director down to the sub-station level police inspectors. ${ }^{4}$ The governing party naturally wanted an election conducted under the auspices of its patronage appointees and a new cabinet naturally wanted the rascals out. By the early 1930's, this spoils system in local politics was a national disgrace. The government tried with new regulations to curb the worst abuses, but, in general, the political tactic of widespread personnel transfers and retirements accompanying cabinet changes continued unabated. ${ }^{5}$

As political party influence in Japan declined in the 1930's, the Home Ministry looked for alternate methods to maintain and to extend its influence locally. Its bureaucrats led the Campaign for the 
Economic Rehabilitation of Farming Villages (Nōson keizai kōsei undō), a local self-help movement directed by governors to alleviate the worst economic consequences of the depression in the farming villages, which by 1937 had committees in half of all Japanese villages and towns. ${ }^{6}$. Home Ministry officials also assiduously cooperated with the Election Purification Campaign (Senkyo shukusei undo) which was the brainchild of Home Ministry bureaucrat Tazawa Yoshiharu (1885-1944). Tazawa and career Home Ministry official Gotō Fumio (1884- ) in 1935 organized a national campaign and established governor-supervised Election Purification Committees in each prefecture.

The Sino-Japanese War (1937-1945) opened another avenue for Home Ministry penetration of the villages through public mobilization to support the expanding war effort. Prefectural governors chaired prefectural committees composed of community leaders under the Central League for General Mobilization of the National Spirit (Kokumin seishin sōdöin chūō renmei) and its successor the Central Headquarters for National Spiritual General Mobilization (Kokumin seishin sōdōin chūō honbu). The Home Ministry's Regional Affairs Bureau Director Hazama Shigeru (1893- ) in 1939 planned another local reorganization based on the traditional village structure, the village (burakukai) and town councils (chonaikai) and the neighborhood association (tonari-gumi). According to his plans, a neighborhood association system would be established in each village and town to cooperate with the central government by publicizing national policies like campaigns for spiritual mobilization by uplifting homefront morale, by increasing production, by bond rallies, and by scrap metal drives. ${ }^{7}$

Political party leaders recognized Home Ministry designs and they also knew their hard won status and prerogatives had steadily declined throughout the 1930's. Their own misdeeds, graft, corruption, and venality alienated prospective supporters. Political terrorism also exacted its toll among party leaders. Military influence in the government expanded with the China War mainly at the expense of party influence. Party leaders believed that an attractive solution to their problems was the formation of a strong, new political party, dominated by them and committed to promoting national unity to overcome the 
crisis confronting Japan. A new party, however, implied an end to traditional party factionalism.

Factionalism plagued both major parties, the Seiyükai and the Minseitō. Hatoyama Ichirō led the former's "orthodox" faction and Nakajima Chikuhei (1884-1949) headed its "reform" wing. The public identified Hatoyama as a "liberal" because he refused to support nonparty, national unity cabinets, maintained an anti-military posture, and prohibited Seiȳ̄kai members from joining any national unity cabinet. The party's poor showing in both the 1936 and 1937 general elections had undermined his leadership and forced Hatoyama into an alliance with Kuhara Fusanosuke (1869-1965) to hold his position. Only 66 of the 175 Seiy $\bar{u} k a i$ members belonged to the so-called Kuhara faction.

Nakajima Chikuhei made his fortune as founder of the Nakajima Aircraft Corporation and then entered politics. His unilateral assumption of the Seiyükai's directorship for its "reform" wing split the party open in 1939. Maeda Yonezō joined Nakajima in leading his 97 member faction and both men consistently supported the idea of a new political party. Another proponent of a new party was Yamazaki Tatsunosuke (1880-1948), expelled from the Seiyñkai in 1934 for accepting a cabinet portfolio.

By mid-1940, the Seiyūkai was the second largest Diet party with 168 seats but factionalism lessened its ability to function as an effective, cohesive bargaining agent. Its members anticipated that a new political party would restore their fortunes in the political arena.

The Minseito was the Diet's largest party with 169 seats and, while it was more cohesive than its Seiȳukai rival, factionalism did exist. Nagai Ryutarō (1881-1944), controlling about 35 Minseitō members, advocated a new party because he believed that as long as the parties represented special interests, national unity could not be achieved. ${ }^{8}$ Machida Chüji (1863-1946) led the 130-man Minseito mainstream majority and opposed the formation of a new party as long as the Minseito was the largest organized group in the Diet. ${ }^{9}$

The Diet's splinter parties like the right wing, nationalist Tōhōkai (Eastern Society) holding 11 seats; the rightist, pro-army Kokumin domei (Nationalist League) with 11 seats; the more moderate Shakai taishūtō (Socialist Masses Party) commanding 37 seats; and the leftist, 
antifascist Nihon musantō (Japan Proletariat Party) with three seats had little hope of ever capturing power in the existing Diet. This realization helps to account for the early and sustained enthusiasm their leaders exhibited for the formation of a new party.

The Socialist Masses Party was originally an amalgamation of several moderate proletarian parties opposing capitalism, communism, and fascism but it gradually drifted to the right. By 1938 the party proposed a "national party" to prosecute the China War and tried the following year to unite with the Töhökai for that goal. ${ }^{10}$ The Tōhokai's leader was Nakano Seigō (1886-1943), a brilliant orator and political independent who believed that only a new party could break the privileged political elite's stranglehold on power. Nakano started the Tóhokai in 1938 and hoped that a new party would totally reform the status quo bureaucracy making it responsive to the people's needs. ${ }^{11}$

\section{Imperial Rule Assistance}

Among all parties there was little commitment to the existing order. No leader appeared to champion the parties' cause against the burgeoning army and right wing ascendancy because party chieftains believed that compromise with these elements better served their interests. The Nazi German war machine's smashing military triumphs in Western Europe appeared to confirm the effectiveness of a oneparty system to the already predisposed Japanese politicians. ${ }^{12}$ The embarrassing spectacle of the Japanese political parties, snared by the appeal of a new order, competing with each other to disband voluntarily surely showed the shallow roots of the party system in Japan. Such an assessment appeared confirmed with the founding of the Imperial Rule Assistance Association (IRAA), a curious amalgam that, whatever else it lacked, produced plangent rhetoric.

Participation in Prime Minister Prince Konoe Fumimaro's (18911945) so-called new order was the lure for party dissolution. Konoe himself convened a commission composed of representatives of the cabinet, both Diet houses, finance, academe, the right wing, the media, and the diplomatic corps to give shape to an all-encompassing national association to complement the new order. On October 12, 1940, this commission officially established the Imperial Rule Assistance Association following six acrimonious sessions and a series of compromises 
involving the IRAA's leadership in local branch offices, its goals, and its political character. E. H. Norman, a student of the Japanese political scene, probably best described the IRAA as an awkward mixture of various personnel types and trends with an even more confused platform. ${ }^{13}$

Rather than an alleged monolithic, totalitarian style political party, the IRAA reflected the pluralistic Japanese state that had developed under the Meiji Constitution. According to that document, only the emperor, through the ultimate decision making authority which was his alone, could unify the entire structure. This forced the respective spokesmen of government institutions to compete for the imperial favor in order to legitimize their decisions. By 1940 an extremely complex, pluralistic system existed which meant that the unification of political power desired by "new order" proponents had to be accomplished in one of two ways. Either the constitution could be amended or a new, all-embracing political party to unite all the pluralistic elements in Japanese society could be created. Amending the constitution, because of the document's sacroscant character as a gift of the revered Meiji Emperor (1852-1912), would be difficult and possibly involve lése majestè (in fact not a single word of the constitution ever was changed) as well as conflict with vested special interests in the social, political, and economic order.

The creation of a supra-organization satisfactory to all colorings of political opinion was the lesser of two evils. Predispositions and preconceptions about the new order, exemplified by the scores of alternate proposals for its structure, should have warned Konoe that tampering with the status quo would produce an unlooked for reaction.

The IRAA lacked unity. Too many diverse preconceptions about the new organization meant that no one wanted to give up their particular pet project for a new party, for national reform, or for a national defense state. ${ }^{14}$ It was not so much everyone trying to catch the "new order" bus as it was everyone trying to drive that bus. Instead of national unity and a totalitarian party, two contending camps appeared to do battle over the IRAA's future. The army, nationalist rightists, and pro-new party Diet leaders supported a strong, political IRAA. The Home Ministry, conservative rightists, the financial com- 
munity, and anti-new party Diet men preferred either a non-political association that they could control or one so weak that it would only minimally affect their activities.

Major General Mutō Akira (1892-1948), the War Ministry's Military Affairs Bureau director, long advocated a "one nation-one party" form of government and had been in contact with Diet leaders like Maeda Yonezō about implementing such plans. ${ }^{15}$ Other Bureau officers who shared Mūto's goals were Colonel Iwaguro Hideo (18971970), the Bureau's Military Section head and a man with widespread contacts in the political and financial communities; Colonel Kawamura Saburō (1896-1947), director of the Bureau's Military Affairs Section, and his subordinate Lieutenant Colonel Maki Tatsuo (19011975); and Cabinet Planning Board member Colonel Akinaga Tsukizō (1893-1949). Their ideas represented the culmination of a persistent strain of the Japanese army's strategic thinking dating from World War One. Simply put, army planners believed that an essential ingredient for military victory in future wars was a united civilian homefront supporting the war effort. By 1940, they envisaged a Nazilike new order as the basis for Japan's national defense and planned to consolidate all national associations in a strong political structure to achieve national unification. ${ }^{16}$

Army spokesmen Akinaga and Maki had participated in the IRAA preliminary meetings and argued that non-bureaucrats, i.e., new, reform oriented men, be made IRAA branch chiefs. ${ }^{17}$ The Military Affairs Bureau's goal was the creation of a regional basis of political support for army policies by extending its influence at the local level. They expected Reservist Association members to fill branch and community council executive positions and thereby form the nucleus of a new political order. This plan failed because the army divisional commanders, who would have the responsibility for administering this regional program, thought that the branches' nature and work made the prefectural governors the natural leaders. ${ }^{18}$

Home Ministry bureaucrats thought likewise and they had fought the Military Affairs Bureau's attempt to take over their regional community council network. Former Home Ministry official Miyoshi Shigeo (1898- ) recalled that the ministry wanted its prefectural governors to serve as IRAA branch chiefs and the community councils 
used as the lower administrative level of the new order's regional apparatus. ${ }^{19}$ Vice Home Minister Hazama Shigeru defended these positions throughout the IRAA preparatory meetings and the Home Ministry strengthened its own regional position when in September 1940 it standardized and consolidated the community councils nationwide as well as established a council with subordinate tonari-gumi of about ten households in each village, town, and city. ${ }^{20}$

Rightists who advocated sweeping national reform opposed these Home Ministry plans to appropriate IRAA branches for ministry advantage. This amorphous grouping, labeled by the police as "reformist," opposed the so-called corruption and decadence of the "old order," attacked the established political parties, and promoted its own schemes for national reorganization along state dominated lines. Among the prerequisites for any new order, reform rightists believed, were a state controlled economy and a monolithic political party.

The other rightist grouping, the ideological or traditional right, traced its origins to the traditional ultra-nationalist patriotic societies like the Kokuryükai (Amur River Society) and the Genyōsha (Dark Ocean Society). Traditional rightists rejected the political party system and the electoral process as Western imports unsuited for the Japanese and instead claimed that only the emperor had the power of political legitimization. Both factions lacked commitment to the status quo, but they perceived antipodal remedies for their dissatisfaction. Reformists opted for an "advance" to what, they believed, was a more modern, i.e., totalitarian, form of government. Traditionalists chose a "retreat" to a golden age which they identified as synonymous with the pre-Westernization period.

Traditional rightists, men like Kobayashi Jun'ichirō (1880-1953), Baron Ida Iwakusa (1881-1964), and the doyen of the traditional right Baron Hiranuma Kiichirō (1867-1952) demanded a non-political IRAA because they feared that a strong political party would lead to a strong cabinet that could usurp imperial prerogatives. Unlike their reformist counterparts and the Military Affairs Bureau personnel, they rejected as anti-kokutai i.e., contrary to the special Japanese characteristics derived from the Imperial institution, any totalitarian "fuhrer principle" leading to a "one-nation, one-party" system. ${ }^{21}$ Consequently, 
they resisted the creation of IRAA nationwide cooperative councils. ${ }^{22}$ Prime Minister Konoe tried to mollify these foes by replacing his Home and Justice ministers with Baron Hiranuma and Yanegawa Heisuke (1879-1945), a retired general with traditional rightist leanings.

So doing, Konoe lost support among reform rightists like Nakano Seigō, retired army Colonel Hashimoto Kingorō (1890-1957), a selfstyled expert on plotting abortive coups, and retired Admiral Suetsugu Nobumasa (1880-1944), a spokesman of the reform right. They prescribed a thorough renovation of the existing status quo by the creation of a new, centralized political party that would exercise extensive powers over the national economy in order to establish a national defense state. The Cabinet Planning Board bureaucrats and army officers like Colonel Akinaga supported such economic thinking and had developed a master plan for a state run economy that would unify all economic controls under a single authority and divorce control over production from ownership and capital investment. Gō Seinosuke (1865-1942), the chairman of the Japan Economic Federation (Nippon keizai renmei), typified the hysterical reaction of the financial chieftains when he denounced the Board's proposal as likely to obstruct industrial growth, divorce the nation from the principles of kokutai, and probably cause the breakup of the Japanese family system. ${ }^{23}$ One suspects it might even reduce profits. A "red smear" campaign engulfed the IRAA causing its much needed monetary contributions from the large financial institutions, especially the Sumitomo and Mitsubishi banks, to dry up. The zaibatsu also invested against the IRAA as the army learned when it discovered that zaibatsu funds underwrote the ferocious denunciations by traditional rightists of the IRAA. ${ }^{24}$

Traditional rightists played on the communist phobia to oust the IRAA Secretary General Count Arima Yoriyasu (1884-1957) whom, despite his peerage, they regarded as a subversive because of his twenty year involvement with the agrarian guild movement. Allegations abounded that Arima had allowed "communists" (easily identifiable as "disguised" converts from socialism (tenkō) and as former Shöwa $k e n k y \bar{u} k a i$ members) to infiltrate the IRAA. The sensation created in 
March 1941 when the police arrested 17 Planning Board officials for communist activity seemingly confirmed the worst suspicions. ${ }^{25}$

It also arrested the economic new order as the Planning Board underwent reorganization. Following Arima's resignation, the IRAA received a similar housecleaning. Home Ministry bureaucrats Hazama Shigeru and Kumagai Ken'ichi (1895- ) became the IRAA's new Organization and General Affairs Bureau directors respectively and prefectural governors assumed directorships of the IRAA's regional branches transforming that organization into a Home Ministry satrapy. The IRAA lost at the national level; it lost at the prefectural level; and it even lost its financial shirt along the way.

As the IRAA's prestige slipped away, so did the parliamentarians' self-induced euphoria about using the IRAA as a means to regain political stature. While a political party-less Diet promoting national unity by example might be desirable, without political parties to enforce in-house Diet control, the danger of chaos and legislative paralysis existed. The former party leaders faced the major administrative task of establishing in-house negotiating groups to govern committee assignments, to agree among themselves on joint action on votes on government proposed legislation, to allocate responsibility for questioning government officials, and to systematize the use of chambers by members. ${ }^{26}$ Though controlled by Diet men, the newly organized IRAA Diet Bureau did not have the constitutional sanction to participate in managing the Diet. To fill this administrative void, in late 1940 a Diet Members Club (Giin kurabu) was formed, based on universal Lower House membership. While ostensibly a voluntary club, incumbents either joined it or lost their opportunity to speak on the Diet floor. ${ }^{27}$ This at least provided a facade of political unity as opponents of party dissolution like Hatoyama Ichirō and members of the defunct Socialist Masses' left wing, purposely excluded from representation in the IRAA's Diet Bureau, joined the Club. Such nominal, disgruntled club members promptly began to question the Club's constitutionality because its officers concurrently served as IRAA Diet Bureau members.

When the 76th Regular Diet Session (December 26, 1940-March $25,1941)$ reconvened after its New Year's recess, Kawasaki Katsu (1880-1949), a protege of Ozaki Yukio and a non-joiner of the Diet 
Members Club, questioned the IRAA's constitutionality by contending that the constitution only authorized the Diet and ministers of state to discharge the exercise of imperial sovereignty. ${ }^{28}$ Ozaki himself demanded to know the legal basis for an organization in which the prime minister concurrently served as director. With these constitutional points as an opening, Kawasaki spearheaded an assault to cut the IRAA's budget request then awaiting Lower House approval.

Supporters of Prince Konoe who, nevertheless, favored different leadership in the IRAA, formed the Imperial Hotel faction around former Seiyūkai Board of Director's member Hara Sōbei (1891-1950), the pro-army, rightist sympathizer Tsugumo Kunitoshi (1893-1972), and former Minseitō member Miyazawa Taneo (1887-1966). Altogether 351 Diet members endorsed this aim, mainly from the defunct Minesitō and Seiyūkai's Nakajima and Kuhara factions plus splinter parties. $^{29}$

Those excluded from the Imperial Hotel faction, including all former Socialist Masses members, minority wings of both major parties, the rightist, one party advocate Akamatsu Katsumaro's (18941955) followers, and followers of the right-wing socialist Kamei Kan'ichirō (1892- ), naturally gravitated to the Central Restaurant (Chūō tei) faction. Kawasaki, army critic Makino Ryōzō (1885-1961), and liberal Ashida Hitoshi (1887-1959) organized this group that eventually had 84 adherents. They opposed a politicized IRAA and instead proposed that the IRAA limit itself to non-political activities with an accordingly reduced budget. ${ }^{30}$

Home Minister Hiranuma finally broke the budget deadlock in late February 1941 when he explained to Diet Budget Committee members that the IRAA simply was a public association to cooperate with the government and promised that the IRAA would be reorganized immediately after the expiration of the current Diet session. A majority of members then defeated Kawasaki's proposed budget by 259 votes to $54 .^{31}$

Hiranuma based his characterization of the IRAA as a public organization on the 1900 Public Security Police Law (Chian keisatsu $h \bar{o})$. According to that statute, all political associations, all persons holding public meetings with a political purpose, and all public organizations as well as assemblies had to register with the police to 
insure security and order. The law forbid active duty servicemen, police officials, religious clergy, teachers, women, and minors from joining a political association. Police reserved the prerogative of disbanding any assembly, home ministers could forbid any association, and policemen who actually attended and supervised these assemblies could order them suspended. ${ }^{32}$

This legislation's impact lay in its exclusiveness. When any association desiring legal status registered with the Home Ministry, it had to be classified either as a political or as a public association. That proviso made it impossible for the IRAA to mobilize a national organization outside the existing political parties in order to control the army and end the China War. If the IRAA went political, it excluded more than half the population as a potential base of support. If it went public, however, it could include those individuals, but only at the expense of being forbidden to engage in political activity. A public organization, in practical terms, could not campaign for the election of specific candidates, nominate or endorse the election of specific candidates, or act as an organization on behalf of specific candidates in election campaigns.

Hiranuma's statement created a vacuum in the political world. No political parties existed to nominate and to campaign for candidates, but no political association had yet replaced them. A general election would require a new, specifically political institution. The IRAA not only failed to attain national political solidarity, but its public status also complicated an already jumbled political scene.

\section{Election Reform Attempts}

Concurrent with the IRAA's formation, the Konoe cabinet tried to make a sweeping change in the election laws. The Meiji Constitution specified that public elections (minsen) determined representation in the Diet's Lower House. By 1940, the Japanese electoral system rested on the medium sized electoral district, a system that divided each prefecture into districts containing three to five seats and ranging in size from one district per prefecture in sparsely populated areas to seven in Tokyo. Nationally politicians contested 466 seats in 122 electoral districts. Section 8 , Article 78 of the election law 
fixed the maximum tenure of members at four years from the previous general election.

In the early 1930's, in response to questionable election practices and the spoils system, election reform plans gained momentum at the cabinet level. A significant reform occurred in 1934 when the cabinet established a public election management system for conformity in election campaigning and financing, defined the election campaign period and prohibited campaigning beyond that time, and reduced candidate expenditure per voter from 40 to 30 sen, about 15 cents. The latter would, in theory, enable more candidates to stand for election by reducing election campaign costs. Home Ministry bureaucrats enforced the new regulations thereby increasing their already significant role in the administration of the electoral process. ${ }^{33}$

Prince Konoe's new order rhetoric quickened the tempo of election reform proposals by those who favored facilitating the election of men committed to the ideals of a reinvigorated Diet to complement the new order. Suggestions included reducing Diet membership, enfranchising only male household heads, nominating candidates by recommendation committees, redrawing the electoral districts, revising campaign regulations, and reforming the Diet system itself. ${ }^{34}$ Not so curiously, Diet incumbents themselves, if not openly opposed to any reform, preferred cosmetic gestures that could not affect their positions within the legislative structure. Feeling ran high against such status quo thinking. Kido Köichi (1889-1977), just before becoming Lord Keeper of the Privy Seal in June 1940, had informed Konoe that he could not support any new party movement that only realigned the established political parties. Instead, Kido believed, a new election law would allow a completely different type of candidate to emerge and replace the tarnished professional politicians. ${ }^{35}$ One of the Konoe cabinet's highest priorities was election reform. ${ }^{36}$

During the fall of 1940, the Konoe cabinet convened several conferences with the Home and Justice ministers, Cabinet Planning Board and Cabinet Legislative Bureau members to work out plans for electoral reform. They gave particular attention to a recommendation system for nominating candidates by special candidate analysis committees composed of community leaders not affiliated with any political party. Such a system, widely employed in Japanese munici- 
pal elections, would establish a parallel nomination system to contest the established political parties' traditional stranglehold on the candidate nomination process.

The Home Ministry proposed a "pyramid" style recommendation system that would originate within the community councils, extend through a county and then a prefectural level committee supervised by the ubiquitous prefectural governor. These committees would recommend approximately twice the number of candidates relative to available seats, but independent recommendation groups would also be legally recognized. The Home Ministry planners hoped to break down the existing jiban network and to replace those politicians of the "old order" with political newcomers endorsed beyond the political party councils. Given the ministry's penetration of the community council system, the plan would have given the Home Ministry control of the election process from candidate nominations to ballot counting. Further conferences outlined an election law proposal using the prefectural size electoral district while reducing representatives from 466 to about 300. Candidate recommendation committees would form on the basis of the Home Ministry's proposal. ${ }^{37}$

Proposals reducing their numbers and taking the nominating process out of their hands moved Diet men to produce their own election reform plan. Maeda Yonezō directed the IRAA's Diet Bureau and he instructed Kiyose Ichirō (1884-1967), formerly the disbanded Kokumin domei's chief secretary, to prepare comprehensive election reform proposals. Kiyose chaired the Diet Bureau's Extraordinary Election System Investigatory Department and its members produced a report rejecting the notion of reducing the Diet's size and proposing a recommendation system contingent on acquiring 100 voters' endorsement in any electoral district. Maeda presented these self-serving designs to Konoe in late November $1940 .^{38}$

The following month at its Extraordinary Central Cooperative Committee Conference, the IRAA unveiled its ideas about election reform. Committee members rejected the prefectural sized district, favored increasing the number of representatives, endorsed a recommendation system, and vigorously supported a proposal that enfranchised only male household heads. ${ }^{39}$ Former Shöwa kenkyükai director Gotō Ryūnosuke (1888- ), now IRAA Organization Bureau 
director, envisaged a recommendation system with the IRAA's regional cooperative council network that could select capable candidates both from among professional politicians and from other qualified persons. ${ }^{40}$ Although never openly stated, these regional councils would neatly by-pass the Home Ministry dominated community councils as well as circumvent candidate endorsement by the political parties.

By late December, meetings among Diet leaders, the Home, Justice, War, and Navy ministers and their attendent election experts thrashed out a plan to abolish universal male suffrage in favor of enfranchising only male household heads. They aimed not at reducing the electorate (although that was inevitable), but at establishing a suffrage based on the traditional Japanese familial system and presumably dominated by the Home Ministry. War Minister Tojo Hideki gave the army's support for such a plan and, following still more characteristically Japanese decision making, a January 20, 1941 cabinet decision set four main points for electoral reform. These would reduce Lower House membership to 400, adopt the prefectural size district, limit the franchise to male household heads, and abolish independent candidacies in favor of a system of recommended candidacies. ${ }^{41}$ The cabinet planned to introduce this legislation when the 76th Diet Session reopened on January 21 following the New Year's recess.

All their efforts proved nugatory. As serious difficulties plagued Konoe's IRAA, factions re-formed in the Diet, and the prince's own popularity nosedived, he sacrificed all other controversial reforms. In a secret meeting among Konoe, Tojo, Navy Minister Oikawa Koshirō (1883-1958) and Diet members, the latter agreed to waive their right to interpellate cabinet ministers' Diet speeches and promised to adopt all resolutions unanimously. In exchange, the cabinet withdrew about a third of its scheduled legislative bills, including the controversial election reform bill. ${ }^{42}$

Stymied by the election reform compromise, in February 1941 Konoe, referring to the tense national and international situation, unprecedently extended the tenure of all elected representatives-national, prefectural, and local-a full year. Home Minister Hiranuma, who seemed to relish relaying Konoe's concessions to the Diet, explained to the Lower House members that an election would adversely 
affect government and popular efforts to consolidate a national defense state order. ${ }^{43}$

Diet tenure extension meant that traditional election practices and the existing election law would continue unchanged. It represented a victory for the former party leaders because, despite backing for electoral reform by the powerful War and Home ministries and popular sentiment, exemplified by resolutions at the IRAA's cooperative councils' meeting, favoring reform, they had averted any meaningful reform detrimental to their established political positions. Rather than being forced to campaign for re-election under a radically revised election law unfavorable to them, former party leaders got the chance to reassert their own authority in the political party-less Diet.

\section{Re-Emergence of Diet Factions}

Diet Bureau director Maeda and the Diet Members Club tried to expand Diet influence by introducing the Diet system of committee decisions implemented by an administrative bureau into the IRAA. The IRAA's leaders rejected the proposal and opted instead to strengthen the IRAA's branch and bureau system to allow not only professional politicians but also any qualified man to advance within the IRAA structure. ${ }^{44}$ Nevertheless, even after the April 1941 IRAA reform, the Diet Members Club buzzed with rumors about a Diet-led IRAA reorganization and a bicameral Diet Club. Political maneuvering lasted throughout the summer of 1941 but ultimately failed because of Konoe's unwillingness to support a new political party; because a majority in the House of Peers strongly opposed a single club, believing Lower House members would dominate it at their expense; and because the Diet Members Club directorate feared the plan might disrupt Club unity. ${ }^{45}$

Dissatisfied with the Club leaders' vacillation, middle echelon Diet members (mainly younger third termers with some freshmen and second termers) tried to fill the Diet's political void by forming a new Diet negotiating association. Countering this threat to their positions, the Diet Club directorate, whose members were the former leaders of the defunct parties, appointed Maeda, Nakajima, and the former Seiyükai director Shimada Toshio (1898-1947) to devise a negotiating club as the basis of a new party thus stealing the initiative from the 
younger members. ${ }^{46}$ The inevitable Japanese preliminary committee subsequently invited 349 of the 434 Diet members (32 vacancies existed) to join but, old enmities being stronger than new unity, excluded the former Hatoyama faction, Kawasaki Katsu's followers, and the left-wing of the former Socialist Masses Party.

Altogether 303 members formed the Yokusan Diet Members League (Yokusan giin dömei, hereafter Yokudō) on September 2, 1941. To the chagrin of junior Diet members, the former party leaders continued their control by dominating the Yokudö's decision making general affairs committee. Outmaneuvered by their political elders, the disgruntled young Turks lay in wait for pretexts to challenge again the Yokudo directors.

Further factional bickering appeared against an international backdrop. Following the Nazi invasion of the USSR in June 1941 and the steady deterioration in Anglo-American-Japanese relations, 27 Diet members wanted publicly to support the Axis against the AngloAmerican combination. In October the Yokudo leaders rejected their request as premature. Now 156 strong, the resolution's backers defied Yokudo orders and formed The League to Accomplish National Policy (Kokusaku kantetsu domei). Faced with this large-scale, open defiance, the Yokudo directorate reversed itself and approved the League as a friendly society. League opponents correctly interpreted their inconsistency as weakness and non-Yokudo Dietmen used the episode to censure Yokudō leaders for promoting factionalism and reviving the abuses of power associated with the former party era. Yokudo weakness also encouraged opponents to exhibit greater independence by forming their own Diet negotiating groups.

On November 10, Hatoyama Ichirō's, anti-military critic Andō Masazumi's (1876-1955), and Kawasaki Katsu's factions as well as Ozaki Yukio amalgamated as the Dōkōkai (Fraternity Association). Police political analysts described it as an anti-government party. ${ }^{47}$ Two days later, National Policy League members and members of splinter parties organized the Asia Development Diet Members Association (Köa giin kai) which the police dismissed as "a weak union of like thinkers." It signaled, however, the restoration of characteristically multifaction negotiating groups as in previous Diet sessions. ${ }^{48}$

War Minister Tojo became Prime Minister Tojo that October and, 
when he officially opened the 77th Extraordinary Diet Session (November 16-20, 1941), he had to work with a fragmented Diet represented by the Yokudō, 334 members; Dōkōkai, 35; Köa giin kai, 26; Döjin kurabu (Comrades Club), 8; Giin kurabu (Diet Members Club), 11; and 19 independents. ${ }^{49}$ Controversy marred even this brief, four day session when during a Budget Committee session Yokudō representative Miyazawa Taneo attacked budget opponents whose actions, he claimed, weakened war bond investment, interfered with material planning, and contributed to shortages. His cavalier impugnment of their motives and honor infuriated Dōkōkai members and provoked Kōa giin kai adherents demanded his censure. ${ }^{50}$ Fifteen former Socialist Masses members withdrew from the Yokudo over the affair and with Döjin kurabu followers formed another Diet negotiating group, the Dai ichi hikae-shitsu (First Lobby) described and dismissed by police as not exceeding a confused jumble of splinter parties for the purpose of having the right to speak on the Diet floor. The episode graphically underlined that factionalism still existed and appeared to be growing more pronounced in the ostensibly party-less national unity Diet.

On the eve of the greatest war in Japanese history, the civilian political sector appeared dangerously divided. The IRAA, despite superficial appearances reinforced by strident new order rhetoric, was not a locus of authority or even of significant influence. By directly challenging the existing political, administrative, and economic order, the IRAA had uncovered deep rooted disputes among the power sharers of Japan. Its reorganization simply papered over these cracks in the national unity frame by transferring top IRAA management personnel and depoliticizing that association. Similarly, dissolution of the established political parties did not really alter traditional political alliances in the Diet. The members of faction ridden parties reconstituted new factions by creating Diet negotiating groups. There had been no reform of the political world, no national election had established a base of support for the new cabinet and its policies in the Diet, and no institution had satisfactorily mobilized the homefront to support the vast new war against the West. It fell to Prime Minister Tojo to resolve these problems. 


\section{Chapter II}

\section{Organizing the Wartime Election}

\section{The Homefront Faces a New War}

Pearl Harbor marked a momentous change in the United States from peace to total war but in Japan, at war with China since 1937, the transition was less apparent. Great initial excitement and apprehension quickly gave way to the daily routine. The battlefield triumphs tumbled pell mell-Pearl Harbor, Wake, Singapore, Javabut these were really just abstractions announced by a fanfare of martial music and blared at the public by loudspeakers. Even passing interest in the war seemed to disappear after the February Singapore victory. Homefront Japan perplexed foreign newsmen still there and, detecting no major changes to accompany the new war, they complained about everything being so normal. ${ }^{1}$

Changes of course did occur. Speculators hoping to turn a quick profit generated a runaway stock market that matched an engorged black market, indirectly fattened as the government announced food rationing measures. Clothes rationing lacked impact since the drab styles already testified to the success of the "Luxury is the Enemy Campaign." It did spark rumors that toilet paper, soap, and toothpaste would soon join the ration list prompting writer Nagai Kafū (1879-1959) to wonder if the winning side would have the dirtier women. ${ }^{2}$ Even so, urbanites were better off than their north-eastern country neighbors who spent their long nights in darkness because electric shortages and kerosene rationing restricted home lighting. The looser wartime atmosphere, and probably the darkened rooms, caused parents worries about their daughters' morals. Jingoism and chauvinism appeared more openly in the streets as professional agitators like Akao Bin (1899- ) harranged passers-by against the use of English words or delivered philippics about America and Britain.

Generally, life went on as before. When the government censors forbade the showing of American or British-made movies, movie theaters could replace John Ford's "Stagecoach" with Leni Riefen- 
stahl's Nazi paean "Triumph Des Willens." Beethoven or Bach concerts and recitals, the opera, live theater, and even the red light district operated as before Pearl Harbor. Prime Minister Tojo, never accused of frivolity, attended the January sumo matches where consecutive sellouts showed the taste for distraction and pleasures that the public masked only when the authorities demanded a martial and disciplined visage.

Similarly no great changes had marked Tojo's ascension to Prime Minister. His was the tenth cabinet in the past five years and it promised to be no better or no worse than its predecessors. Tojo did hold three cabinet portfolios, Prime, War, and Home Minister, but he hoped to use the latter to eliminate mutual jealousy and overlapping functions between the civil and the military police thereby strengthening internal security. ${ }^{3}$ He depended on his hand-picked deputy Yuzawa Michio (1888-1963), a career Home Ministry bureaucrat, to guide him through that ministry's bureaucratic maze. Tojo also reorganized the IRAA leadership by replacing its vice-director Yanegawa, an old rival, with his trusted friend Reserve Lieutenant General Andō Kisaburō (1879-1954). Home Ministry domination of the IRAA continued as Hazama Shigeru and Gotō Fumio retained their posts and high ranking police official Yokoyama Sukenari (1884-1963) became its secretary general.

Pearl Harbor did accelerate existing government imposed restrictions on individuals and on political institutions. A December 8 police dragnet swept up over 500 political dissidents, suspected spies, and left-wing sympathizers. That same month the 78th Extraordinary Diet Session (December 16-17, 1941) approved stringent new regulations on speech and assembly, but not before it extracted Tojo's assurance that the government designed the legislation to control groups which might obstruct the war effort and not political parties. ${ }^{4}$ The new law required all associations and publications to re-register with the Home Ministry. No longer was registration a pro forma exercise but one on which the continued existence of the association or the publication depended. Since all political and public associations had 30 days to re-register with the police or face automatic dissolution, failure to report to the police reduced 200 political clubs to 43 and eliminated about half of the existing 800 public associations. ${ }^{5}$ 
The Tojo government also tried to capitalize on the initial public reaction to Pearl Harbor by promoting nationalistic, patriotic sentiments with radio broadcasts and mass public rallies like those of December 10 when Reservist Association members opened "Mass Meetings to Annihilate America and Britain" at eight Tokyo locations and drew 200,000 listeners. Propagandists did not need to improve on the continual battlefield victories but they did inflate personal exploits when war news was less spectacular.

\section{Election Spadework}

By tapping the stimulated national morale, Tojo planned to use the upcoming election as an instrument to further the war effort. A national election, actively mobilizing the public by creating a heightened war consciousness, offered the chance to prepare the Japanese people psychologically for protracted total war. Such preparation would eliminate the possibility of a breakdown of civilian morale that Japanese military leaders believed responsible for Germany's World War One defeat. A major government goal then was for the election campaign to develop a vast, didactic, national unity campaign to promote homefront sacrifice for the war effort.

As premier, Tojo faced the legacy of problems left by the IRAA; he had to restructure the domestic political framework by resolving the exact relationship among the government, the IRAA, and the Diet. $^{6}$ Tojo could not just ignore the Diet because all government drafted legislation and appropriations, the latter vital given the mushrooming military budgets, had to be approved by the Diet. The reappearance of Diet factions disturbed Tojo not only because they openly divided the national representatives into cliques inimical to political national unity but also because he personally lacked the caliber of dependable Diet support that he deemed necessary for the war effort.

A top secret Metropolitan Police Board evaluation of Diet representatives rated 138 of 430 incumbents as having:

.... a weak recognition of the situation, aimlessly adhering to the old state of affairs, and who are continually in their speech and conduct anti-national policy and anti-government or are recognized as personalities who are ideologically unsuitable to serve as representatives. 
These "unsuitables" included among others, all former Socialist Masses' members, Dōkōkai leaders Hatoyama Ichirō, Andō Masazumi, Kawasaki Katsu, Ozaki Yukio, and liberal Ashida Hitoshi. Another 207 members the police regarded as lukewarm opportunists who

... take positive action sympathetic to the situation and are recognized as personalities who support national policy and are not anti-government in speech or conduct.

First and second termers and middle echelon incumbents, who were the bulk of the former party leaders' followers, comprised this lot. This left only 85 members who enjoyed the government's complete confidence. One achieved this status by

... complying with the situation, taking the initiative to set an example for the accomplishment of national policy, and having the ability to perform the duties of national representatives. ${ }^{7}$

Loyal supporters, it turned out, were the former leaders of the disbanded political parties. New party advocates like Akita Kiyoshi (1881-1944), the ex-Communist and reborn right-winger Akamatsu Katsumaro, Maeda Yonezō, Nagai Ryutarō, Nakajima Chikuhei, Ōasa Tadao (1889-1959), Okada Tadahiko (1878-1958), and Yamazaki Tatsunosuke were among the "reliable" 85.

According to the constitution, the only way a prime minister could build a dependable, pro-government base of support in the Diet was by calling and winning a national election. In a move that followed practices of previous party governments, Tojo hoped that the general election would confirm his new cabinet's authority and create a basis of political support in the Lower House. ${ }^{8}$ The didactic election campaign would complement political unity by promoting public support for the war effort and the election results would be the first step in the creation of a monolithic political party staffed by pro-Tojo functionaries. For these reasons, Home Minister Yuzawa at a February cabinet meeting acknowledged that only an election could advance the war effort. ${ }^{9}$

The cabinet resolved on February 18, 1942, that:

The importance of this election is the opportunity to plan the elevation of a pure political consciousness, the renovation of domestic politics, and the establishment of a yokusan Diet. ... We believe that this priority should advance the great work of leading Greater East Asia. ${ }^{10}$ 
A yokusan Diet, a catchphrase popularized by Konoe's new order campaign, meant a uniquely Japanese Diet that based itself on kokutai principles and through which a national defense state to meet wartime requirements might to established. ${ }^{11}$ The Information Bureau wedded these themes when it distributed 60,000 wall posters depicting an army supply column struggling through the Burmese jungles and superimposed slogans like "The Election Builds East Asia and a New Diet" or "Nationally Build an Impregnable Fortress: Internationally Magnificent War Victories."

Diet renovation would be the first phase of political reform. Again to use contemporary jargon, Diet renovation meant that the elimination of "old order" abuses would enable "suitable new men of talent" to enter and to reform the political system. So-called new men (in the 1942 election this was the generic term applied to all first time national level candidates) being above regional and personal interests would presumably contribute all their energies to create a broad based national unity that would be the political component of the national defense state. Less abstractly, the destruction of the existing jiban system would allow younger men, more independent from local pressures exerted by the community leaders-party politicians alliance, to be elected.

Although the cabinet officially approved the general election in February, more traditional, prosaic election measures began as early as November 1941 when the IRAA prepared for the prime minister a Diet response document that provided answers for interpellations expected to arise at the 77th Extraordinary Diet Session (November 16-20, 1941). This secret document's gist was that the IRAA as an organization should not participate in a national election campaign. ${ }^{12}$ Election preparations continued in December as the police started their customary background investigations of likely candidates. Tojo's reshuffling of Home Ministry personnel was another traditional preelection maneuver. In mid-October 1941, the prime minister conducted a small-scale reorganization by appointing career Home Ministry officials Tomeoka Yukio (1894- ), Imamatsu Jirō (1898-1967), and Narita Ichirō (1894-1959) his respective Tokyo Metropolitan Police Board, Police Bureau, and Regional Affairs Bureau directors. A few other minor transfers involving three governorships and three 
police directorates also occurred. Yuzawa, Narita, and Imamatsu drafted the major January 1942 reorganization that reassigned 12 governors and 31 of 46 police directors including police directors of the seven largest prefectures. These sweeping changes, the official communique announced, would guarantee homefront order and prepare for the upcoming general election. ${ }^{13}$

Military Affairs Bureau director Mutō Akira and Major General Satō Kenryō (1895-1975), the Bureau's Military Affairs Section director, provided an unlikely additional push for an election. According to Mutō, the government anticipated a protracted war and believed that an election would exert a tremendous influence on national unification that was essential for fighting such a war. Mutō's zeal for an election came from his conviction that the collapse of German homefront morale caused German military defeat in World War One. An election could serve as the springboard for a new, monolithic political party that could properly guide Japanese homefront opinion and thus avoid a repetition of the German experience. ${ }^{14}$ The Military Affairs Bureau's planners' fundamental ignorance about national administration and the electoral system, however, caused fears that if they attempted to try to run the election by themselves, Home Ministry officials might try to manipulate army instructions to their own advantage. ${ }^{15}$

In late December, Mutō and Satō began meeting with Home Ministry representatives Yuzawa, Imamatsu, and Narita as well as Chief Cabinet Secretary Hoshino Naoki (1892- ) to plan overall election strategy. Lacking detailed background knowledge about elections, Mutō later admitted and Satō grudgingly confirmed, that they had no alternative but to listen to the Home Ministry experts' opinions. ${ }^{16}$ This resulted in the tactical implementation of election policy being entrusted to Hashimoto Seinosuke (1894- ), a long time associate of Election Purification Campaign promoter Tazawa Yoshiharu and Gotō Fumio.

At Gotō's behest in early 1942, Hashimoto visited the Home Minister's residence where Yuzawa explained what the election planning committee wanted. The general plan favored a candidate recommendation system but hoped to avoid the impression of a government rigged election because that would make the election worthless. 
Hashimoto, Gotō, Tazawa, and IRAA secretary general Yokoyama conducted additional election planning and consulted Yamazaki Tatsunosuke and Nagai Ryutarō. Both these Yokudō leaders thought that a new political organization especially created for the election might also serve as a stepping stone for a new political party. Hashimoto personally opposed such thinking and, backed by Yuzawa, his plan for a temporary political organization to nominate and to campaign for candidates became the official policy.

Tojo favored retired General and former Prime Minister Hayashi Senjūrō (1876-1943) as the new organization's director, but Hayashi's previous run-ins with Diet politicians as the leader of the controversial "Eat and Run" cabinet of February to June 1937 made him unacceptable to the election planners. Eventually the choice fell on ex-premier General Abe Nobuyuki (1885-1953) who met important criteria. He had political experience and his relations with the Diet were better than the average general's although this was as much a function of his bland personality as of any political views. Abe had made his mark as an administrator, not a combat commander. Additionally, his eldest son married Privy Seal Kido's eldest daughter which provided Abe with entry into court circles. Abe was a political mediocrity, but he had fortuitous qualities that made him acceptable to diverse political factions.

Yuzawa, Tojo, and military representatives Mutō and Satō approved Hashimoto's election proposal draft that contained the plans for committees of influential citizens in prefectural branches to recommend candidates for the election. This represented the fruition of a decade of Japanese political thought directed at circumventing the political parties' monopoly on candidate nominations. Moreover, despite the army's preponderant influence in national affairs, election planning and control remained in its traditional center, under Home Ministry auspices.

With election planning well underway, the government slowly revealed its election policy. Initially Tojo spoke in generalizations such as hoping that an election would prove the chance to unite government and people to build a new order, a remark, incidentally, that drew applause in the Diet. ${ }^{17}$ Yuzawa revealed to Diet members, who naturally would be the most affected, that the government was con- 
sidering calling an election in April provided it did not provoke excessive disorder and Tojo announced that barring a change in the situation, he would not extend incumbents' tenure. ${ }^{18}$ By the end of January, Narita indicated to Diet members that a candidate recommendation system might be used in an upcoming election. ${ }^{19}$ Another piece of election strategy was Yuzawa's promotion to Home Minister in mid-February because, as the official explanation read, the homefront situation and forthcoming general election required a full-time Home Minister. ${ }^{20}$ These election preparations dovetailed with the military successes and, after the conquest of Singapore, the cabinet officially announced its election policy.

At the February 18 cabinet meeting, Tojo officially announced the election's objectives as mustering total national power in wartime, solidifying homefront resolution for the war effort, and establishing a renovated Diet composed of capable, talented men. He added that the government hoped that the election would elevate homefront political awareness to rejuvenate both domestic politics and Greater East Asia. ${ }^{21}$ Again an election poster exemplified Tojo's appeal. A bust illustration of a young pilot, eyes heroically skyward, provided the backdrop for slogans exhorting "One Hundred Million En Masse Conduct a Proper Election." Almost as an afterthought, the artist inserted a miniaturized infantryman, slogging along in full field pack, in the lower left hand corner. A vicarious vote for the young pilot's bright face apparently had more appeal than one for a grimy soldier or grizzled political veteran's visage.

Home Minister Yuzawa explained the basic election doctrine contained in the position paper entitled "The Outline of the Basic Campaign for the Accomplishment of the Yokusan Election" (Yokusan senkyo kantetsu kihon $y \bar{o} k \bar{o}) .{ }^{22}$ Successful prosecution of the Greater East Asia War through the creation of a "fresh, powerful" Diet was the election objective. The election itself, Yuzawa continued, represented the opportunity to raise homefront morale, to harden the public will for victory, and, by eliminating all "evil past practices," to provide the chance for suitable qualified men to enter the Diet. One surmises that the "suitable qualified men" would also have the good sense to support wholeheartedly the Tojo cabinet. A non-political, didactic or "enlightenment" (keimō) movement would accompany 
and complement the election campaign by mobilizing public associations like the IRAA and the neighborhood associations to participate non-politically in the election. All orders would come from above as regional governments would implement locally the cabinet's election campaign guidelines.

A didactic election campaign was the ideal objective. By participating properly in a mass participation election, voters would demonstrate the popular consensus behind the Tojo government. ${ }^{23}$ In such a show election, however, the "us versus them" distinction is crucial to insure proper voting for the proper candidates. The call to eliminate past abuses, an indirect but transparent criticism of the jiban system, certainly implied that incumbent politicians would be replaced by "suitable, talented men," the so-called "new men." This impression created the dichotomy between old (incumbents) and new (political neophytes) in the public mind and thereby generated the overriding tension of the entire campaign, a tension conspicuously absent in typical show elections.

An "enlightenment" campaign would rally all citizens in a national unity crusade. Being non-political, the "enlightenment" campaign neatly circumvented the Public Security Police Law's restrictions. That enabled the government to mobilize all citizens and public associations for its homefront solidarity campaign either directly, through proper political participation in the election campaign, or indirectly, by non-political participation in its "enlightenment portion."

\section{The Imperial Rule Assistance}

\section{Political Organization Council}

The government could not legally nominate an election candidate slate because the Meiji Constitution required public elections (minsen), making government recommendations (kansen) illegal. The disbanded political parties had previously conducted this election prerequisite. To fill the political void, Tojo, acting on the advice of the election planning committee and after careful screening, invited 33 prominent leaders of the public and private sectors to his official residence and requested their assistance in forming a new political association. 
Police analysts regarded all seven selected Lower House members (six Yokudō), as fully sympathetic to cabinet policies. ${ }^{24}$ In addition to Yokudō leaders Maeda, Nagai, and Yamazaki, former Minseitō members Katsu Masanori (1879-1957) and Ōasa Tadao plus former Seiyükai members Okada Tadahiko and Ota Masataka (1886- ) were selected. Both Ōasa and Okada served on the Yokudö's general affairs committee while Ota affiliated himself with the pro-army Giin kurabu.

Six businessmen lent their expertise to the committee. They were the Oji Paper Company owner and Mitsui banking tycoon Fujiwara Ginjirō (1869-1960); Hirai Hachisaburō (1866-1945), Kawasaki shipyards and steamship lines president and the director of the Greater Japan Industrial Patriotic Association; Ogura Masatsune (1875-1961) of the sprawling Sumitomo concern; the financier and cabinet advisor on economic policy Baron Yabuki Seizō (1883-1950); Yūki Toyotarō (1877-1951), Director of the Bank of Japan; and Fujiyama Aiichirō (1897- ), Japan Chamber of Commerce director and an entrepreneur holding business interests in Taiwan, Korea, and Manchuria.

Former Home Ministry officials dominated the bureaucrats called together by Tojo. IRAA officials Yokoyama Sukenari and Gotō Fumio, both Home Ministry almuni, joined with ex-Home Ministry bureaucrat Endō Ryusaku (1886-1963) and Count Kodama Hideo (1876-1947), the Home Minister for the Yonai cabinet. Ishiguro Tadaatsu (1885-1970), an Agriculture and Forestry Ministry bureaucrat who now chaired the Agrarian Patriotic League, rounded out bureaucratic representation.

Five retired military officers, including former premier Abe, reform rightist Admiral Suetsugu, and IRAA vice-director Andō Kisaburō joined the assemblage. The other two officers were General Koiso Kuniaki (1880-1950), who never let involvement in two abortive 1931 coups interfere with a rewarding career capped by the premiership in 1944, and a political non-entity, selected to balance army-navy representation, Admiral Takahashi Sankichi (1882-1966).

Besides Suetsugu, two traditional rightist conservatives, former Kokuhonsha (National Foundation Society) member Ōta Kōzō (1889- ) and Baron Ida Iwakusa gained representation. Other members included Gōdo Takuo (1877-1956), the naval ordnance expert and Kokusaku kenkyükai member; Ōkochi Masatoshi (1878-1952) 
president of the Scientific Research Center; Count Saki Tadamasa (1893-1971) Imperial Agriculture Association chairman; Sengoku Kōtarō (1874-1950) Industrial Patriotic Association Central Committee chairman; Shimomura Hiroshi (1875-1957) IRAA official, Kokusaku kenkyükai member, and Asahi newspaper vice-president; Taki Masao (1884-1969), involved with the Kokusaku kenkyükai and Showa kenkyükai; and two journalists, Japan Newspaper Association president Tanaka Tokichi (1877-1961) and the legendary Tokutomi Sōhō (1863-1957) still active at 79 as owner-manager of the Kokumin newspaper.

This was the cream of the Japanese civilian elite and a who's-who among the non-governmental wartime leadership. Graduates of the most prestigious Japanese universities, 15 from Tokyo Imperial University alone, they had risen to the pinnacle of their chosen professions as 16 of the 33 were former cabinet ministers while 18 held peerages. Despite the group's diverse expertise and background, their salient feature was conservatism.

The government made no attempt to balance reform and status quo aspiration as had been done for the 1940 IRAA preparatory committee members' selection. The 26 member IRAA group had two businessmen while the 1942 committee had eight. Similarly, seven had Home Ministry connections in 1942 but only two in 1940. Some overlap between the two committees existed as eight men served on both. Most notably absent in 1942 were the hard-line national reform advocates like Arima Yoriyasu, Nakano Seigō, Hashimoto Kingorō, and Akita Kiyoshi. The five retired servicemen (only one in 1940) represented both a concession to wartime exigencies and an attempt to capitalize on the military's prestige. The election planners took the IRAA lesson to heart and minimized reform, likely to stir disorder, by selecting men with similar idological perspectives. The rubric, after all, was homefront national unity.

Home Minister Yuzawa explained the cabinet's election policies to the assemblage and then government representatives withdrew from the conference room so that the chosen might deliberate "free" of official influence. ${ }^{25}$ After a short conference, the members unanimously vowed "to devise suitable methods to anticipate the establishment of a strong yokusan Diet structure in order to prosecute successfully the 
Backgrounds of Imperial Rule Assistance

Political Organization Council Personnel

\begin{tabular}{|c|c|c|c|}
\hline Cabinet Level Post & Peerage & $\begin{array}{l}\text { Tokyo Imperial } \\
\text { U. Graduate }\end{array}$ & $\begin{array}{c}\text { IRAA Planning } \\
\text { Committee (1940) }\end{array}$ \\
\hline \multirow{2}{*}{$\begin{array}{l}\text { Prime Minister } \\
\text { Abe }\end{array}$} & Andō & Endō & Goto Fumiō \\
\hline & Endō & Godō & Ida \\
\hline \multirow{2}{*}{$\begin{array}{l}\text { Home Minister } \\
\text { Goto Fumiō (Okada)* } \\
\text { Kodama (Yonai) } \\
\text { Seutsugu (1st Konoe) }\end{array}$} & Fujiwara & Goto Fumiō & Maeda \\
\hline & Godō & Ishiguro & Nagai \\
\hline \multirow{2}{*}{$\begin{array}{l}\text { Finance Minister } \\
\text { Ogura (3rd Konoe) } \\
\text { Yūki (Hayashi) }\end{array}$} & Goto Fumiō & Katsu & Ōkōchi \\
\hline & Hirai & Kodama & Okada \\
\hline \multirow{2}{*}{$\begin{array}{l}\text { Education Minister } \\
\text { Hirai (Hirota) }\end{array}$} & Ida & Ōasa & Ōta Kōzō \\
\hline & Kodama & Ogura & Suetsugu \\
\hline \multirow{4}{*}{$\begin{array}{l}\text { Agriculture \& Forestry } \\
\text { Yamazaki (Okada \& } \\
\text { Hayashi) } \\
\text { Gōdo (Abe) } \\
\text { Saki (Abe) } \\
\text { Ishiguro (2nd Konoe) }\end{array}$} & & & \\
\hline & Ogura & Okada & \\
\hline & Ōkōchi & Ōta Kōzō & \\
\hline & Ōta Masataka & Ōta Masataka & \\
\hline \multirow{2}{*}{$\begin{array}{l}\text { Commerce \& Industry } \\
\text { Maeda (Inukai) } \\
\text { Fujiwara (Yonai) } \\
\text { Godō (Hayashi \& Abe) }\end{array}$} & Saki & Shimomura & \\
\hline & Sengoku & Yabuki & \\
\hline \multirow{3}{*}{$\begin{array}{l}\text { Communications } \\
\text { Nagai (1st Konoe \& Abe) } \\
\text { Katsu (Yonai) } \\
\text { Kodama (Hayashi) } \\
\text { Yamazaki (Hayashi) }\end{array}$} & Shimomura & Yokoyama & \\
\hline & Taki & Yūki & \\
\hline & Tokutomi & & \\
\hline $\begin{array}{l}\text { Railroad Minister } \\
\text { Maeda (Hirota \& } \\
\text { Hiranuma) }\end{array}$ & Yabuki & & \\
\hline $\begin{array}{l}\text { Nagai (Abe) } \\
\text { Godō (Hayashi) }\end{array}$ & Yokoyama & & \\
\hline \multicolumn{4}{|l|}{$\begin{array}{l}\text { Colonization } \\
\text { Nagai (Saitō) } \\
\text { Kodama (Okada) } \\
\text { Yūki (Hayashi) } \\
\text { Koiso (Yonai \& Hiranuma) }\end{array}$} \\
\hline $\begin{array}{l}\text { Minister of State } \\
\text { Ogura (2nd Konoe) }\end{array}$ & & & \\
\hline
\end{tabular}


objectives of the Greater East Asia War." ${ }^{26}$ They organized the Imperial Rule Assistance Political Organization Council (Yokusan seiji taisei kyōgikai) or Political Council and inevitably named General Abe its chairman since he was the senior statesman present.

Abe designated a sub-committee to prepare the Council's election plans. Working rapidly, that committee resolved to use a candidate recommendation system for the election and to establish a national headquarters in Tokyo with prefectural branches to conduct the recommendations. The Political Council's first general session convened on February 28 and approved these proposals and also decided that prefectural branches would have from 15 to 20 members who would select branch chiefs from among their members. Branches would forward their unofficial candidate recommendations to the national headquarters where the ultimate selection of candidates would be made. Both would cooperate in campaigning for the recommended candidates.

The Council's aim, expressed in its charter, anticipated that the national candidate recommendation system and campaign would produce a yokusan Diet. ${ }^{27}$ Contrary to Yokudo leaders' hopes, the same document declared that the Political Council would dissolve immediately after the election's completion. Subsequent sessions ironed out remaining administrative details.

The Second General Session held March 4 in Tokyo unanimously approved the draft resolution declaring that branch members should be men from diverse backgrounds, above sectional interests, of good character, and with enthusiasm for a yokusan Diet. National chairman Abe had the authority to decide who might be branch members, name the branch director, and even send national headquarters' personnel and other "suitable" persons to staff local branches if the latter failed to employ such edifying men.

Prefectural governors recommended branch members and chiefs whom the national headquarters then approved. ${ }^{28}$ The Home minister previously had notified the governors that Reservist Association personnel were suitable for prefectural branch membership and instructed the governors to consult with the local regimental commanders in selecting the best reservists for their branches. ${ }^{29}$ By March 20, the Political Council had decided on membership for all its local 
affiliates with branches ranging in size from 21 members (Hokkaidō and Shimane) to 13 (Miyazake and Mie). A typical prefectural branch might include three or four local IRAA officials, two or three Greater Japan Assistance Adults Association (Dai Nippon yokusan sönendan) members, two or three businessmen, two or three prefectural assemblymen, and perhaps a high ranking retired serviceman, journalist, or local official. ${ }^{30}$ Budgets, defrayed by members' donations and contributions, ranged from 10,000 to 30,000 yen $(\$ 5,000-15,000) .{ }^{31}$ The Political Council completed its administrative requirements when Chairman Abe submitted an official request for political status to the Home Minister who promptly granted his permission. ${ }^{32}$

Tojo's claim that his cabinet had no direct involvement in these affairs because the Council represented a spontaneous response to a government request was false. The Political Council owed its existence, its organizational structure, its recommendation system, and its chairman to the clandestine government election planning committee. Nevertheless, for its brief two and one half month existence, the Council was not merely a government puppet for it had already compromised itself by allowing former party leaders into its membership.

\section{Reactions to the Political Council}

The former party leaders quickly realized that any candidate recommendation system threatened their very existence. Furthermore, Yokudo leaders, who regarded themselves and their followers as the Diet's pro-government party, saw the election as yet another chance for them to snare the elusive new party chimera. The previous December, the Yokudo had already established a Political New Order sub-committee chaired by Yamazaki Tatsunosuke to study the possibility of a new party uniting the government, Diet, and IRAA. ${ }^{33}$ Reporters picked up these maneuverings and rumors of a Yokudo organized new party gained circulation. ${ }^{34}$ At the February Yokudo general meeting, Yamazaki presented the members his draft proposal calling for the creation of a national political association, distinct from the non-political IRAA, that would work for the smooth functioning of Diet affairs. ${ }^{35}$ Yokudo officials recognized that as their first step in realizing their long term goal they had to neutralize a potentially hostile candidate recommendation system. 
Gaining representation on the national Political Council was a giant stride in counter-balancing the recommendation system. Maeda and Ōasa gained admittance by intimating to Home Ministry bureaucrats the adverse international effects should incumbents, despite government interference, defeat recommended candidates. Subsequently the seven Diet representatives were added to the Political Council. ${ }^{36}$ The spectre of professional politicians entrenched in jiban deliberately disrupting the national unity election certainly troubled the government, but the Yokudö's accommodation by the Political Council was more a mutually expedient compromise. The Yokudo leaders offered a regional political organization locked into the jiban network that the newly minted Council lacked; they offered the basis of a post-election pro-government Diet party; they offered electoral expertise from the candidate's side that was so essential for electing newcomers. The government simply had no reason needlessly to alienate such a powerful and willing ally.

On February 27, the Yokudo membership approved the recommendation system and allowed four Special Executive Committee members, Ōasa, Okada, Nagai, and Yamazaki, to act as liaison agents between it and the Political Council. ${ }^{37}$ Other Diet factions, however, refused to follow suit. The anti-government Dōkökai, for example, after its February general meeting, announced its concern over the recommendation system producing a government-rigged Diet (kansei gikai) thus violating the spirit of the Meiji Constitution. ${ }^{38}$ Throughout the election campaign, Dōkōkai members consistently criticized the recommendation system and the Tojo cabinet's political as well as domestic policies.

The reform rightist Tōhōkai held only 11 Diet members, but it had a national network of 300 branches with 200,000 members. Its leader, Nakano Seigō, disgusted by the IRAA's political impotence, had left it to reconstitute the Tōhōkai as a political party. ${ }^{39}$ After the party's general meeting, Nakano announced that while Töhökai members fully supported the Tojo cabinet's war effort, all its electoral candidates would be recommended in Nakano's name. ${ }^{40}$ Nakano personally believed that the war gave new relevance to his reform program and that the election provided the chance to increase the Töhökai's Diet strength making it possible, in coalition, to implement 
such reforms. He consequently regarded the Political Council as an obstacle to his plans because he was unable to influence its nomination process. Tōhōkai ambitions were revealed when it endorsed 47 candidates and expected to elect at least $20 .^{41}$

Among Diet splinter factions, internal dissension racked the $K \bar{o} a$ giin kai (27 members) and the fragmented First Lobby (36 independents), dissolved itself in late March. The pro-army Giin kurabu's 15 members rallied to the recommendation system but only because their own Ōta Masataka sat on the Political Council. These Diet attitudes ranging from outright support to outright rejection of the cabinet's election plans showed that not even superficial Diet unity existed on election eve.

\section{Mobilizing the Vote}

Various government ministries did try to counteract the former party leaders' presence on the Political Council and the contradiction that their presence seemed to represent for the government's election policies. Their chief method was repetition designed to implant election aims firmly in the public awareness.

Police Bureau director Imamatsu and Regional Affairs director Narita, for instance, issued instructions to all prefectural governors that reiterated the February 19 Basic Outline and summed up police attitudes about the nature of the election. ${ }^{42}$ As a homefront mobilization campaign, the election would enlist the cooperation of the IRAA, Adults Association, Reservist Association, industrial and agrarian unions, and the Greater Japan Women's Association (Dai Nippon fujinkai) with local authorities to conduct an enlightenment campaign promoting homefront unity between government and governed.

While the police recognized that the campaign should be conducted according to constitutional provisions, it still offered voters the chance to "sweep away" candidates "clinging to the old state of affairs" or those having "dishonorable connections" that hindered the war effort. Police made every effort to insure mass participation as they warned that persons who advocated an uncontested election or suggested a limitation on candidates would not be tolerated. In order to increase voter participation, the government increased polling stations and asked employers to give their workers time off for voting. 
A high voter participation ratio would reverse the 1930's growing voter absenteeism trend and "prove" the election's success. ${ }^{43}$

Additionally, on February 19, the government promulgated election themes it believed worthwhile. Surely a little imagination might have produced something better than the stereotyped trumpeting of "the Japanese mission to drive Western aggressors from Asia as a step in constructing a new East Asia for a new world order" or the joyless admonition to citizens to endure protracted warfare. ${ }^{44}$

That same day, after a liaison conference among Home, Justice, and Education ministry officials, Cabinet Information Bureau, IRAA and Election Purification personnel, the cabinet distributed directions that divided specific election campaign functions among specific ministries, bureaus, or non-political associations. ${ }^{45}$ The IRAA, Election Purification League, and Cabinet Information Bureau, for example, would produce and distribute sound films for the campaign. Predictably, the Home Ministry enjoyed the greatest role and it joined with the Information Bureau to decide and to disseminate election guidelines for the neighborhood association network.

The early February cabinet decision on March neighborhood association general meeting discussion topics set government policy for the activation of the neighborhood units for the election. With little imagination and less sensitivity, it decided that topics would include the previously announced election themes such as raising national morale, sacrificing for victory, and establishing a yokusan Diet through the elimination of past election abuses. These lackluster subjects reappear verbatim in the Cabinet Information Bureau's March 4 issue of Shühō (Weekly Report), the official guide for neighborhood association meetings. ${ }^{46}$

The government also scheduled a special national neighborhood association session for 7:30 p.m. on April 1 to listen as a national radio broadcast would kick-off the election campaign (officially to begin April 4). To try to insure a large captive audience, the Regional Affairs Bureau notified all governors that "influential members of the regular meeting had to attend" the special meeting, although it suggested no coercive means to insure their participation. ${ }^{47}$ Following this broadcast, each neighboorhood association head would lead a guided discussion about election policy and would ask members simple 
questions about election goals. The ministry recognized human failings by even providing easy sample questions for the unusually stupid or lazy neighboorhood leader. In Tokyo, Police Director Tomeoka Yukio instructed neighborhood meetings to discuss topics like prevention of voter absenteeism and the war effort. It was a wonder that anyone attended such meetings.

In conjunction with neighborhood association mobilization, the police, according to traditional custom, prepared election pamphlets. The one especially designed for the neighborhood associations cautioned its members against discussing specific candidates and encouraged them to talk about desirable qualities for suitable candidates. ${ }^{48}$ Exactly how to discuss an election without mentioning live candidates was left to the members' imagination. The nebulousness irritated local neighborhood association, IRAA, and Adults Association officials who demanded that the police provide specific standards to judge candidates. ${ }^{49}$ The best the police could offer was an invitation to drop by the local police station's election information center or else pick up a free election information handbook. Bureaucrats seemingly designed this latter item to terrify conscientious citizens through an enumeration of an array of potential election law violations that might befall the unwary citizen. ${ }^{50}$

A basic government assumption was that the election campaign would be conducted with a minimum of disruption. That made ambiguity, represented by appeals for homefront unity and patriotism, most desirable for it would not upset any vested interest group. This intentional ambiguity backfired by either causing exasperation among those clamoring for definite candidate criteria or implicitly confirming the preconceptions of persons who took government rhetoric about cleaning out the Diet seriously. The IRAA, the right wing, and the Adults Association all believed, and from the government's standpoint even worse still, acted on the implications of the cabinet's election policies.

\section{Getting in Step}

Invitations for the IRAA's Second Extraordinary Central Cooperative Committee meeting announced that the main discussion topics would be strengthening and renovating the domestic political system 
through a yokusan election. ${ }^{51}$ Prime Minister Tojo's salutatory address acknowledged the IRAA's ineligibility to participate directly in the election campaign, but he requested their cooperation anyway to develop a national movement in concert with the election. Yuzawa recapitulated cabinet election goals, especially the need to renovate the Diet by electing suitable candidates.

Delegates took both ministers literally and the subsequent session's minutes seethed with contempt for incumbent politicians. The existing election law, it seemed, had allowed an unsavory type of professional politician to seize control of the Diet. Electing "new men" would resolve this deficiency and, although members argued over how many new men should be elected, most agreed with Kikuchi Kan (18881948), the founder of the popular monthly Bungei shunjü, that a majority of incumbents were "worthless." ${ }^{2}$

The incumbents and their jiban preserve had little support in IRAA councils because delegates pejoratively identified them as purveyors of Western (American and British) ideas in the Diet. This meant politicians ignored the national interest and instead pandered to local aspirations just to get re-elected. IRAA delegates paid the former parties a back-handed compliment by regarding party dissolution as a sham since party influence still existed and these despicable professional politicians would surely turn the recommendation system to their advantage by manipulating the inexperienced Political Council amateurs or by stealthily infiltrating and then dominating local candidate recommendation committees. ${ }^{53}$ All this two years after the political parties officially dissolved.

Assuming that an enlightenment campaign would "wipe out" antiAxis and pro-Anglo-American ideologies and thus rid the Diet of such pernicious influences, members wanted specific candidate recommendation standards. Election law, however, forbade such specifics so they had to be content with shibboleths like "a patriot" or "a homefront wartime leader" as the ideal candidates. Some unenlightened members even suggested an uncontested election believing that an election in wartime was a waste of time anyway as it interfered with important matters like increasing production. ${ }^{54}$

IRAA delegates exhibited generally great enthusiasm for an election because they believed that the election and enlightenment cam- 
paigns could eliminate the old political order's regional stronghold, thereby renovating the Diet and the nation. They never suspected that the election campaign would ultimately eliminate the IRAA's regional influence. Then again, no one foresaw the major election role that the Greater Japan Assistance Adults Association would play at the IRAA's expense.

The Adults Association, established only on January 16, 1942, was the finished product of over ten conferences among the IRAA, War, Navy, Home and Education Ministries. The prime minister ex officio and vice-director Andō Kisaburō directed this hierarchical organization that stretched from the ward to village to county to prefectural to national level..$^{55}$ Only the name was new since adults' clubs (sōnendan) had been founded in 1929 to combat the spread of socialism in the farming villages. By 1941, there were over 1500 branches with 1.3 million members but these had developed unevenly in rural Japan and hardly at all in the cities. In those prefectures where adult clubs did tap community support and lay a firm foundation, however, the Adults Association, as their heir, became identified as an ardent political force for change. ${ }^{56}$

\section{Getting out of Step}

Since the IRAA's depoliticization, the Military Affairs Bureau chieftains had been casting around for another base of support for a new, monolithic and pro-army political party. ${ }^{57}$ Originally, they favored a Nazi-like SA or SS style elite vanguard since a mass membership association might prove difficult to control properly. In September 1941, however, Military Affairs Branch director Colonel Satō Kenryō instructed Reservist Association members to cooperate actively and join the new mass membership association that eventually became the Adults Association.

The Home Ministry had tried to check this latest army attempt to create a regional support base by proposing that prefectural governors, as the IRAA prefectural branch chiefs, also direct prefectural Adults Association branches. A compromise between the Home Ministry and the Military Affairs Bureau resulted in Adults Association branches being established parallel to the IRAA's regional organization with governors as honorary directors. Colonel Satō then agreed to a mass 
membership association and, by encouraging reservists to join en masse, tried to dominate prefectural branches. ${ }^{58}$

Planning called for Adults Association units in every prefecture, but by the February 1942 Association's Prefectural Directors' Conference, only 34 of 47 prefectures were able to send delegates. Although preliminary committees had targeted completion of regional units in time for the upcoming general election, the remaining branches were not fully organized until late March and consequently were unable to play major roles in the April general election. ${ }^{59}$ The Adults Association itself was incapable of a nationwide, coordinated effort in the 1942 election because it was simply organized too close in time to take such an effective role. ${ }^{60}$ However, where the Adults Association did have deep roots in the local community, it launched fierce attacks against the political status quo.

The Adults Association traced its radical bent to its memberships' comparative youth, the reformist direction legacy from the adults clubs, and the regional reform sentiment stirred up by the 1940-1941 new order movement. Limited evidence indicates that the community leaders of the traditional village order monopolized IRAA village leadership but that technicians like union directors or agrarian guild leaders dominated Adults Association councils. While coexisting in each village, the IRAA branch symbolized conservatism but the Adults Association symbolized reform, a perception in accord with contemporary assessments. ${ }^{61}$ A leading opinion journal characterized the IRAA as representative of a bureaucratic or "old style" power while the Adults Association appeared as a reformist association committed to meaningful national reform. ${ }^{62}$

For the Police Bureau, the Adults Association indeed was too radical. Members of the League for the Construction of a Cooperative Order in the Farming Villages (Nōson kyödötai kensetsu dömei), whom the police considered Marxist sympathizers and anti-kokutai, not only flocked to the new Adults Association but also managed to become prefectural directors in Shimane, Hokkaido, and Fukushima. ${ }^{63}$ Taking no chances, the Police Bureau's Security Section issued a February 10 nationwide warning to all police directors to take steps to prevent the infiltration of the newly formed Adults Association by 
communists who, according to police information, had designs against certain Adults Association branches. ${ }^{64}$

Meanwhile, government election rhetoric itself reinforced the Adults Association members'. self-perception as reform vanguards. Newly promoted Major General Satō Kenryō told delegates at the association's branch chiefs Tokyo conference that only they could perform "political work" like improving economic shortcomings, guaranteeing national livelihood, and expanding production. Andō Kisaburō said he expected the Adults Association to be the election's prime mover for political reform. ${ }^{65}$

Their mandate clear to themselves from these ambiguous speeches, Adults Association branch chiefs promptly went on record as the only association unwilling to help "unsuitable candidates." ${ }^{66}$ Keeping such persons out of the Diet would rid it of Western ideas like individualism, liberalism, and democracy. Only by the elimination of traditional election abuses and the destruction of jiban, the old order's principal prop as well as greatest hindrance to reform, could new men be elected. The enlightenment campaign had to censure "unsuitable" candidates identified as those running for regional and sectional interests or faction and clique members, those who built jiban through corruption, and those only "interested in personal gain," specifically incumbents.

Such was the litany of sins of the former political parties recited with increasing fervor by the anti-party faithful. The Adults Association clearly planned to use the national election, not for national unity with professional politicians, but to promote a drastic reform of the status quo and to expand its own nascent national influence.

The government also found itself contending with fractious associations and individuals who displayed almost a peevish perversity in not participating properly in the election.

Reform rightists comprised such a radical group that expected to play a prominent 1942 election role chiefly because of their self-satisfying assumption that as the prime movers of the Greater East Asia War they should be rewarded by the enactment of their varied domestic reform schemes. ${ }^{67}$ Whatever rightists expected from the Tojo government, it soon became apparent to them that the new government would continue its predecessors' policies and ignore right- 
ists' programs but carefully watch rightists' activities. Similarly, while the idea of a new Diet appealed to those "double patriots," their attitude toward the election became increasingly bitter, especially after the government announced the Political Council's membership. ${ }^{68}$

Only three of the 33 Council members, Ida Iwakusu, Ōta Kōzō, and Suetsugu Nobumasa, could be considered right-wing members in good standing. The Council's seven Diet and six business representatives were more threatening for both were traditional rightist foes. Yet openly defying the government's election policies did not appeal to these chauvinists of the reform right who operated on the premise that they should exercise self-restraint when they critized the election in order to avoid domestic friction in wartime. Alarmed at the traditional direction the election seemed to be taking, their chauvinism forced them into a quandry. ${ }^{69}$

Director Sasagawa Ryöichi (1899- ) of the Kokusui taishütō (National Essence Mass Party) attempted compromise right-wing style when he sent a list of candidate qualifications to the Prime and Home ministers and both services Military Affairs Bureau chiefs that urged avoidance of recommending former Seiyükai or Minseitō politicians, those over 65, communists, socialists, or those who had undergone tenko. Sasagawa identified suitable candidates as consistent supporters of national policy since the China War and those connected with the "patriotic reform camp." ${ }^{70}$ The recipients predictably ignored these self-serving suggestions to clone rightist candidates.

Sasawaga then joined with Akao Bin's Kenkokukai (National Founding Society) and splinter reform rightist groups to form the Patriotic Associations Council for General Election Measures ( $S \bar{o}_{-}$ senkyo taisaku aikoku dantai kyōgikai) which sponsored a rally at Tokyo's Hibiya Park on February 24 to announce rightist election policy. Denounce might better describe the proceedings since the rally quickly turned into a foray against the Political Council because it was incapable of creating a yokusan Diet. Such statements underscored the activist right wing's grave fears that the Political Council would just serve as a vehicle for the defunct political parties to ride to revival. ${ }^{71}$ Assassin Mikami Takashi's (1904-1971) Kódō yokusan seinen renmei (Imperial Way Assistance Youth League) exemplified anti-party phobia at its extreme when it denounced the election as a 
Diet and big business plot to resurrect the defunct political parties. In language reminiscent of rightist anti-election diatribes from the 1930's, Mikami assailed the election for hindering a Japanese renovation (ishin) and giving the "pro-American and pro-British status quo faction" a lease on life. ${ }^{72}$ Mikami perceived that politically not much had changed despite party dissolution and the war and neither had the Metropolitan Police Board's attitude about rightists changed. Officers at the rally warned Mikami against any such future outbursts and confiscated an issue of the League's journal, Yokusan undo (Imperial Rule Assistance Movement). ${ }^{73}$

The greater a particular rightist group's election expectations, the greater their bitterness when their self-deluding prophecies proved barren. Undercover police reported that Akao Bin's Kenkokukai members had great election hopes and were actively collecting campaign contributions to prepare for campaign rallies and pamphlets. Hashimoto Kingorō not only expected his Dai Nippon Sekiseikai (Great Japan Sincerity Association) to enter 30 candidates but also anticipated 10,000 yen $(\$ 5,000)$ to cover expenses. Never a wallflower, Hashimoto even counted on the military assisting his election campaign. Another retired officer, Lieutenant General Ishiwara Kanji (1886-1949) was indifferent about the election. Ishiwara, however, was the Töa renmei doshikai's (East Asian Comrades Association) chief advisor and his noncommittal attitude disconcerted members who planned to run 34 candidates and also to support desirable incumbents. $^{74}$ The militant Nichiren religio-political Rikken yōseikai (Society for the Cultivation of Constitutional Justice) had even greater ambitions, expecting to enter 50 candidates nationally. Battlefield victories surely nutured such grandiose schemes.

Resentment began to build toward the election as the reform rights' fertile plans withered after the government's icy reception. The reform-rightists, in common with the IRAA and the Adults Association, believed what the government rhetoric promised. They all feared that political party leaders presence on the Political Council might lead to a revival of the hated political parties or to the creation of a strong new party that would be dominated by former party leaders at their expense.

To Major General Satō all of the prewar political and social divi- 
sions that he detested seemed to be reasserting themselves in antigovernment or anti-election forms. Around the end of February, he expressed his concern to Tojo that the election campaign might degenerate into an anti-government, anti-military one and disrupt homefront morale. Satō wanted to call off the election. Tojo, however, was aware that the Home Ministry had thoroughly prepared for the election and, although police intelligence did report some unrest, he believed that the police could properly regulate the election. ${ }^{75}$ 



\section{Chapter III \\ The Home Ministry Prepares}

\section{Investigations and Investigations}

Since the Home Ministry supervised election laws and regulations, the police were always active in Japanese elections. The First and Second General Elections in 1890 and 1892 respectively established antipodal precedents for future Japanese elections. The Home Minister recognized that the former would be precedent setting and ordered the police to enforce impartially election regulations. In the latter, the Home Minister directly ordered the police to intervene against opposition candidates to prevent their election. ${ }^{1}$ Like a pendulum keeping proper time by extreme variations, so extremes between strictest neutrality and open interference generally marked patterns in Japanese elections.

By 1942, three different civil police types and the military police regulated elections. The most fearsome was the special higher police (tokko) officer. Commonly known as thought police, he combated the perceived communist menace and preserved national ideological purity from contamination by extremists of either right or left. $\mathrm{He}$ hunted for subversives, but he hunted in plainclothes and tried to mingle with his prey. At election time, he might attend campaign rallies to listen to speeches or check campaign materials to insure that no candidates spread ideological poison.

The secret police (kōtō keisatsu) dated from 1881 and, although the 1935 election reform act technically abolished them, their organization continued under different designations. In the Police Bureau, it became the Security Section's Crime Prevention Department (böhanka); in the Metropolitan Police Board, the Intelligence Section (jöhöka), and in prefectural police directorates, the secretariat (shokishitsu). The secret policeman's job never changed. He collected political intelligence and supervised election campaign rallies, speeches, and political associations. ${ }^{2}$ The political parties intricate development magnified secret police functions because the Home Ministry had a 
vested interest in election personnel transfers and wanted to be on the winning side. The intelligence data that the secret policeman collected during an election campaign could, of course, be put to good use by the party in power and, for that reason, opposition candidates regarded his work as a form of election interference. ${ }^{3}$

Ordinary neighborhood policemen, both the uniformed patrolman and his plainclothes vice-squad counterpart, carried the main burden at election time. The ward patrolman, an intimidating figure in his para-military dark blue uniform, with high button tunic and narrow visor hat, only reinforced that imposing presence with the short sword he carried. He openly circulated through election campaign rally crowds searching for violations and sometimes trying to intimidate opposition candidates' potential supporters. His plainclothes counterpart normally worked on the vice squad stamping out social evils like unlicensed prostitution, underage drinking, and, from 1938, rounding up truant students. At election time, he turned his talents to candidate vice. These three types of police might be augmented by a military policeman who turned up at campaign rallies increasingly since 1936, ostensibly to protect military and national security secrets.

Police activity in the 1942 election followed traditional practices when the Home Ministry ordered Tokyo prefecture police chiefs to initiate background checks of possible candidates and to recommend potential candidates for a general election. ${ }^{4}$ The Home Ministry normally ordered police to conduct such investigations prior to general elections in order to uncover fraudulent candidacies. Furthermore, as election campaign costs mounted in the 20th Century, weaker candidates resorted to corrupt tactics like vote-buying or bribery to try to insure their election and to justify their huge campaign expenses. The police, who regulated such abuses, became quite sophisticated themselves at undercover investigations to try to control such violations. Two examples of vote-buying incidents in the 1942 election campaign reveal the complex machinations that the police had to trace. But the limits of legal police investigation of a candidate's campaign and illegal police interference in that campaign remained subjective. This made it extremely difficult to determine whether or not ordering the police to enforce election laws strictly necessarily meant ordering them to interfere in election campaigning. 


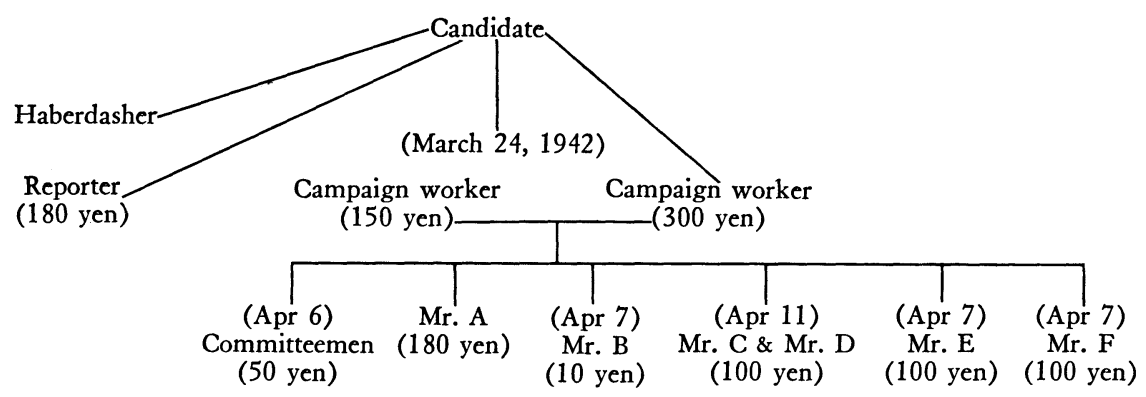

Vote Buying Tokushima Prefecture 1942

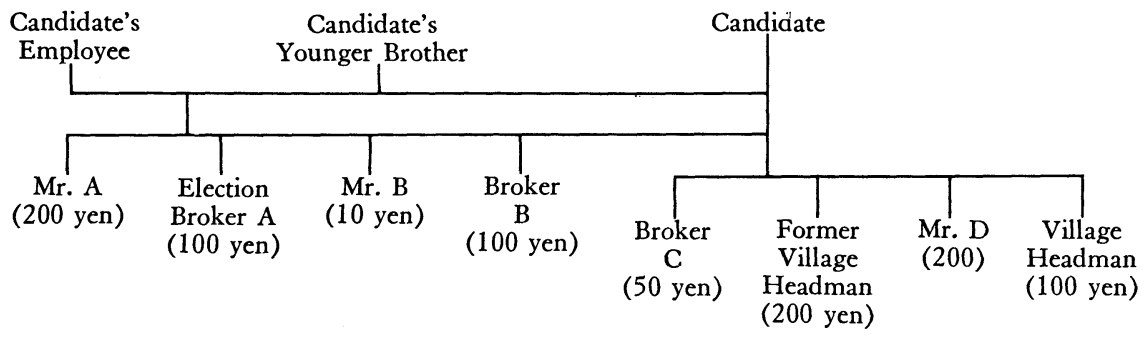

Source: Keihōkyoku keimuka, "Dai 21 kai shūgïn giin sōsenkyo senkyo Hanzai kenkyo no gaiyō(1)," Secret April 22, 1942 in Archive Title 1470 Reel 214, Frame 83875 no gaiyö(1)," Secret April 22, 1942 in Archive Title 1470 Reel 214, Frame 83875 and 83890 .

The 1942 pre-election candidate background investigations, rather than an attempt to influence candidate selection, might be regarded as traditional forms of police activity. Records of previous investigations into the careers and past life of candidates exist that indicate the 1942 variety were not a wartime innovation. ${ }^{5}$

Police conducted the 1942 pre-election candidate background investigations

because of the many qualified persons crowding onto the election stage, it was necessary to investigate before the fact suitable persons for Diet representatives from among those expecting to become candidates and those desiring to stand as candidates. From last December, various preparations went forward and by January 20 of this year, respective police chiefs completed those investigations in their jurisdictional areas. .. .6

On January 12, 1942, the Metropolitan Police Board issued detailed instructions to ward police chiefs on investigation results reporting 
procedures. ${ }^{7}$ Police should base their investigations on potential candidates' "purity of motive" (kōketsu), intelligence, ideological impartiality, and enthusiasm for the war effort. These "strictly confidential investigations" of persons "recognized as suitable as wartime representatives" would be forwarded to the Intelligence Section in two reports, one for anticipated and one for aspiring candidates.

Ward police chiefs submitted 133 names including 42 businessmen, 35 IRAA officials, and 15 rightwing activists from which the Intelligence Section eventually culled 46 names and apportioned them among Tokyo's seven electoral districts as "suitable" candidates. The Police Board revised a final list of "persons suitable as candidates" for a March 18 report to the Police Bureau's Police Affairs Section. It reported 28 men, 12 of whom had participated in the 1937 general election, considered "suitable" to stand as recommended candidates for Tokyo's 31 Diet seats. ${ }^{8}$

Circumstantially it seemed that a direct, causal connection between police recommendations and the Political Council's recommendations existed, since the Council did ultimately recommend 16 police selections. Of these 16, however, eight were incumbents and one a former Diet member defeated for re-election in 1937 at least suggesting that half the so-called "police selections" may have been recommended simply on the basis of their incumbency. Surely, if a direct relationship existed between police choices and the final selection of recommended candidates, the Tokyo police, in an election billed as promoting opportunities for "new men" to enter politics, could have done better than recommending a total of seven newcomers, five of whom lost.

The exact criteria the police used to conclude that 10 incumbents possessed "suitability" as recommended candidates remains unclear. It may be surmised that they weighed incumbent's support of national policies in the Diet and found it wanting. Police probably believed that ex-Socialist Masses or Proletariat incumbents might lessen respect for kokutai and thereby hinder the war effort. For example, exSocialist Masses member Miwa Jyūsō (1894-1956) received police endorsement, possibly because he was the IRAA's Organization Bureau Liaison Department director, but his five former Socialist Masses colleagues did not. Similarly, the police ignored Tokyo's three Dökōkai members, most likely because of the party's anti-government attitude. 
While these documents do show police contempt for incumbents, they do not reveal any direct police influence over the Political Council's decisions. ${ }^{9}$

Together with these investigations, the Police Affairs Section ordered all prefectural police chiefs to upgrade police training for election control. Stressing the election's wartime significance and that it was the first general election in five years, police chiefs designed courses to refresh the patrolman's understanding of election laws and the use of such laws and "other forms of regulation" to prevent disorder and allow the "most important" candidate to win election. ${ }^{10}$ In late February and early March, the Intelligence Section conducted lectures on election law enforcement and the Justice Ministry superintendents received similar lectures. The Intelligence Section also edited and distributed 5,500 election handbooks to police officers as well as providing educational and lecture materials. ${ }^{11}$

At the national level, the Police Bureau helped local police contingency election planning by publication of a primer to aid officers in detecting election violations. This pamphlet, based on factual examples, emphasized that time and again the lowly patrolman's persistence, alertness, and suspiciousness resulted in the arrest of devious election law violators like election "brokers" (men controlling blocs of votes who illegally bargained with candidates) and vote buyers. ${ }^{12}$

In mid-February, the Police Affairs Section standardized, in theory, the pre-election campaign period reporting format. Local neighborhood police would compile a list of aspiring candidates, to include all Diet members, and provide details on potential supporters and jiban. These weekly reports commenced during the first week of March. In mid-March, however, a Home Ministry telephone instruction altered the reporting format to include the candidates' age, political affiliation, possibility of being elected, and jiban resources, mentioning such matters as influential supporters, anticipated votes, and, if applicable, vote totals in previous elections. ${ }^{13}$ Ward police precincts all responded to the standardized format, but, within that framework, the election intelligence materials submitted varied greatly. Tokyo's Takemoto Kuramae Station was a model of reporting clarity with its detailed situation reports, graphs, and charts. Other stations, however, 
contented themselves and their superiors with the briefest possible reports of information apparently gleaned from the morning newspaper.

The well kept records of Kuramae, located in one of Tokyo's commercial districts, provided a glimpse at an example of well organized police control. Kuramae's chief divided his patrolmen into two "reconnaissance units." These two units operated independently, in effect checking on each other's work, and investigated economic and organizational candidate resources as well as the candidates' political "tendencies." A "special" reconnaissance section joined these officers in order to scout election related traffic in their area and its section leader kept track of candidates' campaign finances. An inspection chief relayed patrolmen's reports about neighborhood candidate analysis committees' candidate selections to the precinct chief. Their plainclothes subordinates watched customers in restaurants, teashops, and machiai (meeting places) because the police long regarded such public places as convenient locations for illicit election campaigning or to bribe voters. Apparently plainclothes officers acted conspicuously enough to touch off rumors of an imminent round up of restaurant patrons. ${ }^{14}$

While Kuramae was a model of election organization, the 88 other Tokyo stations and almost 1200 nationwide repeated similar activities in equal or lesser degrees. Each station cast its nets around a neighborhood to snare political tidbits for their superiors. One unforeseen effect of this police election preoccupation was an increase in thefts reported by customers at public baths. ${ }^{15}$

\section{Conferences}

As neighborhood patrolmen conducted their investigations and hovered around teashops scaring off customers, top level Home Ministry bureaucrats applied the finishing touches to their election canvas. A series of national conferences from mid-February to mid-March shaped the ministry's national election policy. The Prefectural Police Affairs Section Chiefs meeting of February 14 launched these sessions. Imai Hisashi (1902- ), chief of the Police Affairs Section, told delegates about the importance of crowd control in wartime and then a 
Military Affairs Bureau representative provided a lengthy explanation about regulation of public meetings. ${ }^{16}$

On February 26, the Prefectural Promotion Branch (shink $\bar{o}-k a$ ) directors met. Home Ministry bureaucrats expected these directors to implement the yokusan election campaign because of the intimate connection between themselves and the neighborhood associations. Regional Affairs Bureau director Narita explained, in a manner fast becoming de rigueur, the election's objectives and stressed the need for a national campaign uniting government and people. ${ }^{17}$

The March 4-7 National Governors' Conference filled in these election policy sketches. This annual policy meeting was the first since the massive January transfer of governors and set election policy guidelines for these key prefectural authorities. Tojo himself gave the opening address and, reminding the assembled governors of their serious wartime responsibilities, he requested their cooperation with the national government to promote a national unity campaign for the war effort. ${ }^{18}$ The keynote speaker, however, was the new Home Minister Yuzawa Michio.

Yuzawa attached so much importance to the speech that he drafted it himself although the minister normally delegated such work to the Personnel Affairs Director. ${ }^{19}$ In protracted warfare, Yuzawa announced, the government hoped that the election would provide a chance for the public to demonstrate their zeal for the war effort. The Home Minister himself desired an impartial election, but he would not tolerate the disclosure of state secrets, speeches to disrupt public opinion or likely to foment domestic discord. ${ }^{20}$ That encapsulated the government's conception of the election; a show election to prove that the public was solidly behind the war.

According to a Home Ministry pamphlet, governors could implement these goals by "carefully guiding and encouraging" election related activities and remaining alert for omissions in election duties. Governors, because of their "insight" into local popular sentiment, would be able to detect any "gaps in national policy" and correct them. Their prompt action to arrest and to prosecute election offenders would "cut away" the "poisonous weeds" of the election world. ${ }^{21}$ These duties represented the growing responsibility of the governors for maintaining homefront wartime order. Their enforcement became 
the topic of the March 13-14 National Police Chiefs' Conference in Tokyo.

Yuzawa presented the opening address and he told his audience that, beyond their normal tasks, he wanted the police to prohibit strictly any speeches or publications likely to obstruct the war effort as well as to control completely any opinions liable to disrupt homefront unity. ${ }^{22}$ Police Board director Tomeoka seconded that theme when he told the police directors that they must be vigilant against any election arguments or pamphlets apt to divulge state secrets, disrupt public opinion, or foment homefront discord. ${ }^{23}$ A Police Bureau pamphlet explained that by increasing patrolmen's election consciousness and cooperating with the Justice Ministry's Procurator's Office, officers would be able to thwart illegal activity, to exert "proper control and guidance" of the election, and to concentrate on the elimination of election brokers' "breeding places." ${ }^{24}$

Chief Procurator Matsuzaka Hiromasa (1884-1960), the Justice Ministry's representative at the conference, supplemented those instructions as he explained that even in the absence of the established political parties, the election campaign might easily give rise to cynics who questioned the election's fairness. Not only must the police control such miscreants, but also they must act sternly to regulate any arguments or speeches critical of Japanese immutable national policy, economic controls, or that might cause popular unrest. ${ }^{25}$

On April 4, higher law courts presidents and chief procurators gathered in Tokyo to listen to Justice Minister Iwamura Michiyo (1883-1965) encourage them to exert their efforts during the election to insure "perfect discipline" among the people. He also desired an impartial election, but the accumulated past political evils had to be eradicated. Despite political party dissolution, there remained many electoral districts where the candidate numbers exceeded available seats. Severe competition in such districts might foster election violations or complaints about government election interference. Judicial and police officials had to make special efforts to prevent such "groundless denunciation" of wartime policies. Chief Procurator Matsuzaka concluded this conference by advising procuratorial officials that "they could not be too severe" when dealing with subversive campaign speeches and literature that could retard the war effort. ${ }^{26}$ 
Opposition meant subversion, dissidence meant treason, and criticism meant anti-war sentiment. These were certainly the ingredients for a show election, but could they be applied to a voting public who had a tradition of wide-open election campaigns? Formulating official policy and executing that policy lost something in the transition.

Neighborhood police actually were impartial in the sense that they trusted no one and watched everyone, even recommended candidates. Several days after the Police Chiefs' conference, the Police Affairs Section ordered precinct chiefs to forward local intelligence about the Political Council branches' candidate recommendations, decisions on such recommendations, and, weekly after April 10, detailed reports on each candidate's election campaign within their respective jurisdictional areas. Required information included each candidate's anticipated votes, election forecast, and observations on the neighborhood response to candidates' campaigns. ${ }^{27}$

The Police Board had Tokyo patrolmen investigate and report, while "avoiding direct confrontation with the candidate or his campaign workers," the strength of each candidate's supporters, his anticipated votes, financial connections, and comment on the candidate's main strength. When the election campaign officially opened on April 4 , the policeman also investigated campaign conditions but had to be "especially discreet in speech and conduct when gathering information." ${ }^{28}$ Headquarters insistence that officers base their required weekly reports on "factual information" probably left many a patrolman at loose ends by Friday afternoon. Doubtless the police did gather some election related political intelligence this way, but it seems more likely that most of the hearsay and gossip swirling around any neighborhood involved, not the election, but immediate daily concerns like complaints about food or clothing shortages.

At the lower judiciary reaches, for instance the case of Iwai Police Station located in Tottori Prefecture's northeast corner, the ideological offenses procurator ordered his subordinates to supervise election laws and also to control ideas "desecrating the Holy War" so that a true yokusan Diet might emerge. With all citizens performing their duty as loyal subjects of the emperor, the election could serve to advance the war effort. Just to make sure that no heretic blasphemed the 
sacred war, he ordered strict control of candidates' election speeches and pamphlets. ${ }^{29}$

No matter how severe these restrictions, by themselves they do not constitute a rigged government election. Missing from all these orders and conferences are any direct orders to the police to intervene in election campaigns in favor of specific candidates. The omission is important. In the case of the 1892 election, Home Minister Shinagawa Yajirō (1843-1900) directly ordered governors in writing to work for pro-government and against anti-government candidates. No such orders appear in 1942. In the 1928 election, Home Minister Suzuki Kantarō (1867-1948) ordered the police not just to restrict campaign rally topics but to enforce strictly these regulations and any other suspected election violations against his Seiyükai's opponents. Again, in 1942 no such orders have yet come to light. One reason may be that the Tojo government expected the restrictions on the press and on public speech would suffice for an orderly election allowing recommended candidates to be elected. ${ }^{30}$

\section{Wartime Censorship}

Press control arrived early in Japan. The government promulgated a press code in 1875 and, eventually during the latter years of the troubled 1930's, the cabinet formed the Cabinet Information Committee as a state information agency to coordinate news dissemination and established a government news agency, Dömei Tsushinsha (Dōmei News Agency). Following the outbreak of the China War in 1937, a Cabinet Information Department held monthly or bimonthly conferences with the publishers of leading Japanese newspapers and magazines. It relayed official warnings about "undesirable" editorials or articles that the government judged adversely affected public opinion and detailed forbidden topics for publishers. ${ }^{31}$ The four major popular monthly magazines, Chūō köron, Kaizō, Nippon Hyöron and Bungei shujū joined this conference and formed the Yonshakai (Four Companies Council).

In December 1940, the Cabinet Information Bureau altered its existing censorship policy from post- to pre-censorship. This meant that all materials for public consumption had to be submitted in ad- 
vance to the Bureau for review and prior censorship, thereby making Bureau approval mandatory before the fact for all publicly expressed opinions. ${ }^{32}$ A government organized Japan Publishers Cultural Association (Nippon shuppan bunka) controlled paper distribution and uncooperative editors quickly discovered their paper supply reduced. In May 1941, the Bureau attached an official censor to each newspaper company and that December Köron and Gendai, right wing journals promoting militarism and emperorism respectively, joined the Four Companies Council. With bureaucratic precision, the name changed to Six Companies Council (Rokushakai). Home Ministry, Cabinet Information Bureau, Procurators Bureau, and Thought Police personnel also participated in the expanding censorship function. ${ }^{33}$

The day after the Pearl Harbor attack, the Information Bureau's Fourth Branch, Second Section (Censorate) delineated the government's published materials policy for editors and publishers. Editions should design "positive" articles to guide public opinion by stressing the justice and unavoidable nature of the war, raising morale, strengthening homefront resolution for protracted war, and increasing hatred of the Americans and British. "Negative" articles like antiwar, anti-government, or subversive stories should be avoided. ${ }^{34}$ The Police Bureau's Peace Preservation and Censorate Sections together with the Metropolitan Police Board Thought Police enforced these latest restrictions.

The Police Bureau Director supplemented this already rigid framework for public expression on February 28, 1942 when he nationally dispatched specifically election related regulations for published articles. $^{35}$ These regulations simply forbid publication of any articles that might disrupt public opinion, be overly critical of the election, oppose the general election, or intentionally try to lessen public zeal for an election. By providing examples of what it considered unfavorable criticism, the Tojo cabinet revealed its fears that the public might think that its election policies violated the spirit of the constitution by suppressing independent candidates as a conspiracy to elect a proTojo Diet or that it was a rigged election. Convinced of the desirability of a consensus of suppression, the Information Bureau relayed an edited version of these police instructions to editors in early March. ${ }^{36}$

These election coverage standards warned editors against criticizing 
the election or the Political Council's recommended candidates. It cautioned them neither to be negative about the election nor to suggest that an election at this time was not appropriate, nor to argue that the election denied the universal male suffrage principle, nor to criticize the Political Council as unconstitutional, nor to attack directly its membership, nor to hint that the electorate should abstain from voting. Additionally, the police forbid the use of blank spaces to replace censored articles. The blank column tribute to the censor's zeal no longer stood out like an island in a printed sea and that perhaps represented a victory for superficial homefront unity.

The government used censorship coercion to try to enforce favorable election campaign reportage by the printed media, but coercion alone does not fully explain the sympathetic treatment accorded the election in print. Newspapermen voluntarily restricted their coverage of sensitive topics as their contribution to the war effort and, at least a year after Pearl Harbor, many public opinion spokesmen (genronsha) actively cooperated with the government in the war effort because they felt a responsibility to do so. ${ }^{37}$ It is true that the government blacklisted writers it considered "uncooperative," but they represented a stubborn minority. The majority either willingly complied with official proscriptions on free expression and portrayed the election restrictions as "being natural in wartime" or explained that whether one liked it or not, restrictions on campaign literature and rallies were as necessary for the war effort as restrictions on gasoline. ${ }^{38}$ If cars could keep going, so, apparently too, could politicians.

More critical and imaginative journalists warned that such restrictions might impede political newcomers trying to make themselves known through extensive campaign rallies or advised the government to enforce impartially regulations for recommended and independent candidates alike. ${ }^{39}$ Newspaper editorialists also cautioned that overmanaging campaign rallies might cause the election campaign to wither away and admonished the government that it would be "suicidal" to interfere in the election because such action would besmirch the election's constitutional character and arouse public mistrust. ${ }^{40}$ Even these journalists restrained themselves because they felt that their unfavorable reporting might be turned against the Japanese by their enemies. They cooperated as much from patriotism as from coercion. 
Home Ministry bureaucrats, one feels, would have liked to standardize all public and private thoughts. This being impossible, they settled for the best alternative--restricting campaign rally topics. The Police Bureau's top secret Instruction 14, issued to all governors on March 26, 1942, set standards for the "control and guidance" of election campaign rallies. ${ }^{41}$ Four days later, the Home Ministry Secretariat notified all police directors of the same orders and instructed them that campaign rallies should serve as "positive methods" of raising morale as part of the overall effort to unify wartime public opinion. $^{42}$ Instruction 14 's sweeping provisions were the most candid government expression of its official election policy.

The opening paragraph expressed government election philosophy as it described the campaign rally as a tool to unify public opinion by the use of "appropriate" police guidance and regulation of campaign rallies. Circulating these rally standards to candidates or their campaign managers would make them aware of (and responsible for) the exact limitations imposed on their campaign rallies. Police officers also had to "anticipate thoroughly and to correct by guidance before-the-fact serious points concerning matters that could result in cautionings or suspensions" of rallies. This type of censorship was pre-publication censorship's illogical conclusion. The patrolman assigned to supervise campaign rallies became responsible for surmising controversial statements by candidates even before candidates uttered them. If the officer suspected, or even intuited, that a candidate's campaign speech "deviated," to use the police vernacular, he had the authority arbitrarily to caution the candidate, warning him not to continue on that topic. Should the candidate brazenly ignore repeated cautions, and it was not unusual that in the excitement of the moment he did, the policeman could order the rally suspended.

The neighborhood patrolman, because in most cases he was the official on the scene, used a type of sixth sense to prevent "deviation" and perfect homefront unity. The system probably led inevitably to abuses. The policeman had to show his dedication to his superior's orders and issuing warnings and suspensions at campaign rallies did tangibly display his enthusiasm. Besides, the officer could get into trouble for a remark a candidate made, but never for one that was not made. Rather than take the chance on the innocence of a candi- 
date's remarks, it was easier to assume no remark harmless. A dramatic upsurge of cautions and suspensions issued by Tokyo police during the 1942 campaign when compared to those issued in the previous 1937 election provided quantitative evidence of this policy's harsh enforcement at campaign rallies.

In 1937, as in 1942, Home Ministry and military police officials issued orders to regulate campaign rally speeches strictly, especially speeches likely to agitate the masses, slander the military, or suggest a popular front. ${ }^{43}$ In Tokyo Prefecture, police issued 891 cautions, ordered 128 suspensions, and made three arrests during the 1942 general election campaign that involved 4,353 campaign rallies conducted by 99 candidates. In contrast, during the 1937 general election campaign, 68 candidates held 3,209 rallies and police cautioned candidates 259 times, suspended 39 rallies, but made no arrests. ${ }^{44}$ Simple extrapolation to compensate for the fewer candidates and rallies would raise the cautions to between 350-375 and suspensions to between 53-56, still dramatically below the 1942 figures.

Police ordered these cautions or suspensions based on six categories of election speech standards similar to the December press guidelines. Category One, premised on protracted warfare, made impermissible any speech likely to influence adversely homefront morale to endure total war. The Tojo cabinet's paranoia about the possibility of a breakdown of civilian morale resulted from their understanding (or misunderstanding) that attributed German defeat in World War One not to military factors, but to a collapse of the German homefront. ${ }^{45}$ The government's election cornerstone was that the election would ratify the war effort by bolstering homefront determination to see the protracted war through and endure all the accompanying privations for the sake of victory.

Potentially appealing campaign topics, the government paradoxically prohibited. Everybody knew about the spectacular battlefield victories, but who knew about Japanese administrative and economic policies in the newly conquered Southern Front areas? Who knew enough to even be likely to cause confusion about the Tojo cabinet's Greater East Asia statesmanship? Yet police had orders not to allow discussion of such topics. These proscriptions hit reform right wingers especially hard since they advocated that the Southern Front areas 
serve as a cornucopia to alleviate homefront material shortages and that zaibatsu interests be excluded from these areas. Also forbidden was any description of the Greater East Asia War in racial terms, another reform right staple. Still, that was not as sweeping as the police forbidding speeches likely to create doubts in public confidence about the government's ability.

Under the rubric of foreign affairs, the second category excluded any campaign oratory that might offend Japan's German or Italian allies or other Axis powers. This ban muzzled "liberal" elements like the Dökōkai and former political party men (stigmatized as proAmerican or pro-British sympathizers anyway) who might criticize fascist and totalitarian regimes. However, to their dismay, traditional rightists found any suggestion that the Japanese should attack the Soviet Union banned and even the discussion of matters that might needlessly irritate the USSR proscribed.

Domestic items subjected to proscription formed the third category and included subjects like intentionally or abusively criticizing the government, its policies, or creating suspicions about its sincerity. Former Socialist Masses and Japan Proletariat Party members discovered that denouncing or abusing the nation's upper classes or encouraging homefront class rivalry were forbidden.

A national unity election did not require a particularistic appeal to workers or to farmers; it required national unity chants and slogans. It also neatly excluded any reform minded candidate from the Tōho$k a i$ or Adults Association from building his campaign based on discontented workers. Official concern about anti-military or pacifist speeches, displayed by the military police during the 1936 and 1937 elections, resurfaced as a strict prohibition against the discussion of military matters. Likewise, discussing material shortages, inciting discontent over the supply and demand of goods, kindling public discontent by exaggerating material shortages, or insinuating that black market scandals involving high government officials existed was taboo. This emphasis only indicated the government's awareness that increasingly widespread shortages existed and these generated both public anxiety and dissatisfaction.

Shortages of fuel, rubber, spare parts, trucks, draft animals, and electricity plagued rural areas. ${ }^{46}$ Even after all the military triumphs, 
no relief from such cutbacks was in sight as strikingly exemplified by long lines of customers waiting patiently to buy such diverse scarcities as shoes and fresh vegetables. Opposition to government economic policy and controls or creating worries about inflation, however, were similary forbidden. Töhökai and Kenkokukai candidates generally ignored these proscriptions at their rallies and police ordered scores of cautions and suspensions for such lapses.

As for the general election, Category Four, government policy aimed more at independents and the reform or traditional rightists; those who might oppose or lessen zeal for an election or even intentionally distort the true government motives for calling an election. It was impermissible to criticize the Political Council or otherwise create a lack of confidence in the government. Categories Five and Six, even more general in nature, banned spreading "wild rumors" or discussing military, foreign policy, or economic state secrets. The 1942 variety "wild rumor" played on the food shortages with lurid descriptions of mothers killing their children because of the lack of food, cannibalism, and the outbreak of food rioting. ${ }^{47}$

Not satisfied with merely regulating what was better left unsaid, Police Bureau Instruction 14 also offered a "guidance section" of what it considered edifying topics. These pedantically stressed the war's just nature and portrayed the Japanese leaders as long-suffering and patient but finally forced to arms for the Empire's prestige and national survival. Victory meant the eradication of American and British military and economic pressure and that meant that the public had to be physically and psychologically prepared to persist in their homefront labors for a total war effort. Elevating national morale would elevate the gross national product. Lastly, candidates might compare front line soldiers' sacrifices to the safe, secure homefront's as examples to exhort citizens to buy war bonds, to perform homefront patriotic service, and to participate in the election. By encouraging proper participation in a didactic election campaign, these guidelines would cement homefront unity.

Incredibly, the Political Council supplemented these police requirements with its own. The Council issued to each recommended candidate an Outline for Guiding Public Opinion (Genron shidō yöryō) because it believed that the establishment of a yokusan Diet 
reflecting the unification of government and public opinion required such guidance. ${ }^{48}$ Divided into five parts, this outline covered topics like homefront morale, Southern Front economic policy, and homefront economic conditions. Recommended candidates, by clarifying the "true nature" of the homefront and international situation, could smash enemy "demagoguery, propaganda, and rumors." Lofty campaign themes would focus on sustaining an indomitable homefront morale and reducing the chance for "ideological plots." Gunma First District recommended candidate Nakajima Chikuhei's kōhō (official statement of candidacy) probably best mirrored these guidelines. It exhorted the Japanese people to accomplish their wartime missions as a race descended from the gods personified by a divine emperor in what literally was a holy war against the lesser breeds. ${ }^{49}$

The protracted war bogey appeared in Political Council instructions to its candidates to tell voters that they must prepare for a long war and not underestimate the enemy. The Southern Front was important in strategic military terms and no sustenance to relieve domestic privation from those areas should be encouraged. Instead, those resources would be used to perfect an invincible defense ring and to prevent vital raw materials from reaching the enemy. Domestic economic messages centered on encouragement to work harder, to produce more, to cooperate with the government to reorganize industry, to buy war bonds, to save more, to restrict purchasing power, in short, to do more and to enjoy less to support the massive war effort.

It was to be an election campaign devoid of political issues. The Council even advised recommended candidates to be "discreet" when arguing about ideas since introducing "enemy ideas" at campaign rallies could have a "reverse effect" on the unification of homefront opinion. Japanese spirit, a popular catchphrase connoting the superiority of the spiritual over the material, the Council warned its candidates should not be over-emphasized nor should natural science be ridiculed. As a concession to the Twentieth Century, a candidate might explain that Japanese spirit could even encompass scientific culture.

As severe as all of these restrictions on campaign oratory were, however, they were not an innovation for the 1942 election. They represented a lamentable continuation of the existing policy of restriction of speech, publication, and assembly, now enforced in the 
name of the war effort. Campaign restrictions merely updated already established government censorship policy and applied it to candidates. Superficially, such sweeping restrictions seemed to ensure the success of the homefront unity election. Most Japanese apparently accepted these restrictions as their contribution or sacrifice for the war effort. The election campaign requirements did not break new ground in the steady encroachment on civil liberties. They merely served as an occasion for existing specific regulations to be applied. Such regulations drained the lifeblood from any dynamic, hard hitting campaign. If candidates totally adhered to such rules, and if the police totally enforced them, the government's didactic election campaign would become reality and the citizen would not only participate, but would have no choice but to participate properly. ${ }^{50}$ Instead of a collision between an immovable force and an unmovable object, however, the electioneering resembled a sumo wrestling match with technique pitted against strength. The more experienced veteran political campaigner's technique could often overcome the seemingly insurmountable strength of Tojo's police power. 


\section{Chapter IV \\ The Candidate Recommendation System and Its Critics}

\section{Initial Reactions}

The Tojo cabinet and the Home Ministry seemed to have concocted a rigid election campaign framework and candidate recommendation system designed to insure a didactic election. From its very inception, however, the presence of former party leaders on the Political Council promoted dissent and disillusionment. The recommendation process itself generated further widespread public dissatisfaction chiefly because the Council endorsed the former party leaders as recommended candidates. Criticism echoed throughout society, appeared in the contemporary press and magazines, and eventually resounded in the Imperial Diet.

Ironically, Political Council Chairman Abe started public criticism rolling when he announced to reporters at a March 9 press conference that, although attempts would be made to comply with regional conditions and aspirations, the fundamental principle for recommending candidates was the candidate's likelihood of being elected. ${ }^{1}$ This so-called "election first philosophy" touched off the campaign's first genuine excitement.

Iwabuchi Tatsuo (1892- ), one of Japan's foremost political commentators, caustically observed that such an attitude gave an unfair advantage to seasoned political veterans with jiban and a Yomiuri correspondent reported widespread public dissatisfaction with the "election-first" philosophy. The Hochi reporter shared such views and wrote that Abe's remark gave "old order" politicians an unfair advantage because, though they obviously lacked the "talent" for imperial rule assistance, they had the connections and the money to get elected. ${ }^{2}$

Home Minister Yuzawa, during a Kobe speech, tried to retrieve the situation by explaining to reporters that Abe really meant that no matter how talented a man, if unelectable, his recommendation had no value. Nevertheless, Yuzawa conceded, that the statement had caused a great deal of inconvenient misunderstanding. ${ }^{3}$ Abe himself 
backtracked and admitted his error, and, in a hauntingly familiar political ploy, blamed the press for distorting his meaning. The Political Council later reprinted this exclusive interview as a campaign pamphlet and distributed 10,000 copies. ${ }^{4}$

Actually, Abe merely recognized the gulf between the cabinet's plan for an ideal election infusing new blood into the Diet and the need to compromise with former party leaders to conduct an election. What seemed to critics like a cynical reassertion of the jiban dominated political party standards that placed personal advancement above the commonweal was an acknowledgement of the fundamental and specialized role political parties (even when ostensibly dissolved) played in elections. Accommodating such tradition, though, hit hardest at political newcomers from the reform right, the Adults Association, and the IRAA who advocated, after all, a Diet renovation by ridding it of traditional incumbent politicians. Their outraged screams naturally reverberated the loudest since without recommendations these political newcomers would be very hard pressed to defeat incumbent Dietmen and renovate the Diet.

Reformists reviled no abuse of the preceding political party era more than the jiban since it remained the cornerstone of the political status quo. Cabinet election rhetoric calling for the "sweeping away of past abuses" seemed to point the way for jiban destruction. The Home Ministry certainly fostered a similar impression by constantly reiterating the need to eliminate traditional election abuses and to mobilize "suitable talent" for the Diet. ${ }^{5}$

While predictably a reform rightist periodical thundered against jiban, surprisingly so did more moderate journals that wanted to "root out" jiban in order to destroy any of the former parties' latent popularity. Adults Association vice director Andō Kisaburō endorsed that opinion when he told a national radio audience on April 1 that the election could destroy the jiban and factionalism characteristic of the former political parties. ${ }^{6}$

Despite such vociferous reactions, the Political Council and the cabinet could no more ignore the existing jiban coterie than a ship in treacherous waters could sail without charts. The Home Ministry knew the politician's jiban's complexity and tenacity as well as the enormous difficulty involved in uprooting all jiban. ${ }^{7}$ The Tojo cabinet 
never wanted all incumbents defeated, only those it identified as opponents and the police evaluation of all incumbents ironically showed the former party leaders as the most consistent government supporters. Election rhetoric glossed over the embarrassing fact that the scapegoats of the 1930's turned out to be the Tojo cabinet's strongest allies. That would have been difficult to explain to anti-party groups like the Adults Association whom the Tojo cabinet also wanted solidly backing its policies. The Adults Association, IRAA, and reform rightists believed the campaign rhetoric they heard and planned to act on it for national political reform. This tension between "old style" jiban dominated politics and the new politics predicated on regional reformist aspirations threatened to erupt and to shatter the homefront unity facade that Tojo hoped to make substantive, not merely cosmetic.

\section{Diet Criticism}

A second major source of criticism directed against the constitutional and legal propriety of using a recommendation system in a national election unfolded in both Houses of the Imperial Diet during the 79th Regular Session (December 26, 1941-March 25, 1942). In the Lower House, the Dökökai spearheaded the assault and the Upper House's Viscount Ōkōchi Kikō (1885-1955) bedeviled Tojo and Yuzawa. The Imperial Diet did not just rubber stamp the cabinet's election policy and candidate recommendation system. Instead, in a manner that cannot be associated with any known "militarist" or "totalitarian" regime, Diet members spoke out against the election, asked tough questions about election policy, challenged the election's constitutionality, and came close to forcing a governmental crisis.

On March 19, Dōkōkai member Andō Masazumi, seconded by the other 36 Dókokai members, launched a devastating attack on the candidate recommendation system. ${ }^{8}$ His interpellation rudely dispells the misconception that the Diet docilely knuckled under to every cabinet demand. Andō demanded that Tojo dissolve the Political Council because it violated the spirit of public elections specified in the constitution. Wasn't the presence of a majority of House of Peers' members (18 of 33) on the Political Council a violation of the constitutional spirit of separation of Diet Houses? What exactly were the standards for selecting Political Council members? Could these mem- 
bers select the most suitable candidates? Tojo, Andō hoped, would provide a clear answer about the election in order to dispel popular suspicion about the election's fairness.

The Tojo cabinet, Andō persisted, claims that it wants a true yokusan Diet, but since the China Incident the present incumbents have "cooperated assiduously" with the government in all national policy matters, more so since the outbreak of the Greater East Asia War. Where, Ando wondered, did the government find defects in the present Diet? ${ }^{9}$ How did the cabinet feel about popular reaction to the Political Council that recognized it as a government fabrication designed only to produce pro-government Diet lackeys? Additionally, government activities such as spreading innuendo that independent candidates hindered the war effort and prohibiting the publication of criticism of the election or its recommended candidates actually amounted to election interference and violated the constitution and election laws.

Six days later, on the session's final day, Tojo submitted his reply to those most embarrassing questions. Evasion characterized his answers, but this should not diminish the important fact that he did reply. The pattern of so-called analogous regimes like Nazi Germany or Fascist Italy ignored such questions (if anyone asked them at all), branded the questioner a traitor and arrested or otherwise harassed this kind of miscreant. Accordingly, other potential dissenters would rethink the wisdom of protest. In 1942 Japan this did not happen. The constitutional tradition and the Imperial Diet's development of parliamentary procedures like the interpellation function forced Tojo to either answer such interpellations or ignore parliamentary custom and the rule of law. Choosing the latter course would deny his own cabinet's legitimacy by placing it beyond the Diet and outside the constitution.

Tojo re-stated the official reasons for an election and he explained how the government had requested aid from influential persons of all professions to try to achieve election objectives. The Political Council resulted and, acting independently of the government, it adopted a candidate recommendation system. Since the government did not participate in that body's formation or its management, Tojo contended that the Council was constitutional. Peerage was not a cri- 
terion for selection. Only fortuitously had Tojo picked 18 peers and he did not attempt to evade the spirit of a bicameral legislature. While there had been criticism of the Council's members, Tojo believed that their experience would ultimately prove the most valuable in selecting the most suitable candidates.

Tojo defended calling the election on constitutional and legal grounds because incumbents' tenures already had been extended a full year past their limit. Andō's charge that most people thought that the government rigged the election and the Council, Tojo equated with slander (which is what Andō intended) since a majority, apparently silent, understood the government's true motives for calling an election. Tojo admitted that the police forbid certain campaign topics but this was natural to preserve "law and order" in a "total war" system.

Tojo then dealt with Lower House critical interpellations by means of time-honored parliamentary techniques such as prevarication, technicalities, and evasions, but not with rubber truncheons. Although strict wartime controls existed on freedom of expression, dissent, as exemplified by Andō's questions, was possible. While the former political parties had unquestionably declined in prestige and authority, the Diet itself had not necessarily atrophied into a moribund condition. As an institution it still commanded respect and government critics in that body did not just vanish into "the night and the fog." Instead, embarrassing Diet interpellations caused political turmoil indicating that the cabinet and Diet members recognized such queries as important elements of the political process.

On March 25 in the final House of Peers' Plenary Session, Viscount Ōkōchi requested Tojo to clarify his government's election policy. ${ }^{11}$ The viscount sarcastically noted that taking all the various standards for recommending candidates into consideration, the criterion for a suitable representative was patriotism. No Japanese lacked that qualification, so there had to be more specific standards. Ōkōchi doubted that the Political Council members could be neutral and unbiased when selecting candidates and he reiterated Andö's contention that the recommendation system was unconstitutional. After all, Ōkōchi wondered, wasn't the recommendation system just legalized government election interference? It was also a dangerous precedent, he 
argued, to allow titled peers to recommend Lower House candidates, peers themselves not being enfranchised. This might also destroy the traditional noninterference policy between Diet chambers. No Japanese, he concluded, would censure the war effort and Tojo's pretext that he needed censorship to maintain law and order amounted to an easy way for him to stifle public opposition and criticism of his cabinet's policies.

Again the weight of tradition forced both Tojo and Yuzawa to sit silently through this withering attack on the cabinet's election policies. Then Tojo stood and explained that because the government had no connection with the Council it had no influence whatsoever over candidate recommendations. The electorate had the final vote on whether or not to elect recommended candidates, so the government could not rig the election. He concluded by expressing his opinion that a blantantly government-fabricated election would only have adverse effects on the government's public opinion leadership.

Next Yuzawa explained that since both nationally and internationally all eyes focused on the Japanese election, the enemy could be expected to try to exploit any public discord for their own advantage. Consequently, the best possible election had to occur and, for that reason, the Home Ministry had to control strictly speeches and actions that might create doubts among the public.

Ōkōchi's interpellation sent shock waves through the Tojo government. If Tojo opted not to answer Ōkōchi, adjourning the House of Peers was the sole legal maneuver open to him. That morning Privy Seal Kido Köichi received a telephone call from a frantic Cabinet Planning Board Director Suzuki Teiichi (1888- ) informing him that, due to Ōkōchi's embarrassing questions, the need could arise to petition the emperor to recess the House of Peers. Baffled by this sudden political whirlwind, Kido hurried to report to the emperor at the palace. When he returned from his imperial audience, more trouble awaited him as Suzuki called again to notify the court that, although the Peers session had just adjourned, with the growing anxiety about the Lower House situation where Tojo was replying to Andō Masazumi's interpellation, the cabinet was seriously considering Lower House dissolution. ${ }^{12}$

The entire affair proved fleeting, but it illustrated that Diet obsti- 
nacy and critical interpellations caused Tojo sufficient embarrassment to make him consider the drastic step of Lower House dissolution. This was especially significant because such an act would have transformed the election into a direct vote of confidence in the Tojo cabinet. The 1937 general election, contested on similar grounds, had ended in government defeat.

Tojo's trials with Diet members did not end with the 79th Session. A week after the Diet's normal recess, Dōkōkai member Ozaki Yukio wrote an open letter to Tojo that denounced the IRAA's and the Political Council's "unconstitutional" election activities. These abuses, Ozaki believed, would lead to a government fabricated election and he advised Tojo to respect the Imperial constitution by abrogating all Political Council candidate recommendations as well as by avoiding election interference in all its forms. ${ }^{13}$ The reform rightist camp showered even more vituperative and unabashed invective on the Political Council and its recommendation system.

\section{Rightists and Recommendations}

On March 12, a cloudy, overcast day, the Ködo renmei, already under police scrutiny for its February polemics against the Political Council, opened its Conference to Establish a Clean Election (Junsei senkyo kisei kyögikai) where members openly maligned zaibatsu and former political party leaders' influence in election campaign planning. Akao Bin's Kenkokukai issued national instructions to destroy the "old political order," although Akao was not especially clear on how to accomplish this. Sekiseikai, Ködō renmei, Töhōkai, and Kinnō makoto musubisha (Association of True Loyalists) members joined forces for an "Election Purification" evening rally on March 27 in Tokyo. Before a crowd of about 100, speakers berated "old order politics," the zaibatsu, and Tojo's election plans. The police cautioned a Kinnō speaker for saying Tojo's election plans were unclear and, as effectively as the cold March wind, dispersed the rally with a suspension order after a Tōhókai speaker told the crowd that the recommendation system was a means to manipulate the electorate. ${ }^{14}$

The police might attempt to stiffle such dissent, but they never completely eliminated it. The reform right, although never regarded as totally legitimate politically by any prewar Japanese government or 
by the mainstream party leaders, could voice its radical and even outrageous opinions in the streets. At the Diet level, members from both chambers asked tough, probing questions about election policies. Even after a decade of decline, the Tojo cabinet could not ignore the Diet because of the latent political power and the traditional legislative functions vested in that institution. In sharp relief to other "totalitarian" regimes, much as people like General Satō Kenryō might have wanted, the Tojo government imposed no Draconian penalties on dissenters in the 1942 election campaign.

\section{Recommending Candidates}

In this milieu of increasing criticism of the Political Council, the National Conference of Prefectural Political Council Branch Chiefs convened in Tokyo on March 22. They represented nearly 800 hastily selected branch members who composed the Council's expedient recommendation committees' regional network. General Abe told the delegates that the recommendation system differed from political party endorsement since its standards did not restrict the Council like a single political party, but made it national in scope. ${ }^{15} \mathrm{He}$ asked the branch chiefs, accordingly, to recommend candidates for the prescribed number of Diet seats in each constituency, but if difficulties in selection arose, an additional name exceeding the limit of seats might be added to their recommendation registers.

Publicly the recommended candidates should be men of "wide experience" who understood kokutai principles, above regional interests, and zealous about creating a yokusan Diet. $^{16}$ A second, classified criteria, however, was the real measuring rod and excluded five types from recommendation consideration.

1. Those who cause fears that lessen national awareness of kokutai.

2. Those whose words and deeds are likely to cause confusion in homefront unity and, thereby, hinder the prosecution of the Holy War.

3. Those whose words and deeds are likely to cause a decline in public trust and confidence in the Political Council.

4. Persons who have committed crimes or who have a contemptuous attitude toward the nation.

5. Persons who have an insolent attitude toward national affairs. Moreover, any person already rejected by the conference will, of course, be excluded from a recommendation. ${ }^{17}$

The Political Council headquarters expected its branches, in short, not 
to consider government opponents and critics for a recommendation when they forwarded their unofficial candidate recommendations to Tokyo by Tuesday, March 21.

General Abe also established a special 22-member headquarters executive committee to analyze and to select recommended candidates both from among branch suggestions and on their own initiative. This important committee included all the Lower House representatives on the Political Council, namely Katsu Masanori, Maeda Yonezō, Nagai Ryutarō, Ōasa Tadao, Okada Tadahiko, Ōta Masataka, and Yamazaki Tatsunosuke. $^{18}$ Council critics widely regarded their selection as "proof" that the former party bosses exerted overwhelming influence in Council decisions. Opponents insisted that these incumbents really joined the Council as Yokudo representatives in a plot to manufacture a new political party following the election. ${ }^{19}$

Grounds existed for such allegations. Ōta Masataka later claimed that he and the other six incumbents on the Council made the final selection of recommended candidates. ${ }^{20} \mathrm{He}$ exaggerated since the police traced right wingers' recommendations to rightist leaders on the Council, but the Diet men did exert influence beyond their numbers during candidate selection. ${ }^{21}$ They held two trumps; a cohesiveness of purpose and an indispensable knowledge of the regional and national political scene, a knowledge that the Council desperately required.

The antagonism that their presence on the Council caused among IRAA and Adults Association members did not offset these advantages but it created endless possibilities for disagreement. The prefectural Political Council branches' membership included an absolute majority of IRAA, Adults Association, and Reservist Association affiliated individuals. ${ }^{22}$ This meant that "old political order" opponents would regionally endorse candidates who had to be in turn approved by the "old order" politicians who dominated the national Political Council. Locally the nod went to political newcomers while the national level, given the predominate incumbent influence, favored the former political party members. ${ }^{23}$

At the prefectural level another element juxtaposed to the former parties' influence was that of the local army regimental commanders. As army representatives, the regimental commanders tried to impose 
their will on the prefectural governors during the selection of candidates. The army's degree of influence on the recommendation process varied from prefecture to prefecture according to the regimental commander's political consciousness, the local governor's strength and political convictions, and the candidate standards employed in a particular region.

In Gunma Prefecture's case, the regimental commander applied significant pressure on the Political Council branch to recommend the army's hand-picked candidates. In a showdown between the civilian and military prefectural authority, Governor Murata Gōrō (1899- ), utilizing to advantage his role as the man who selected the branch members, exerted sufficient leverage on them so that they endorsed his candidate selections. Murata chose his candidates after consulting with the local community leaders. His simple recommendation criterion was that the candidates not embarrass Gunma Prefecture, meaning that, if recommended, they would be elected. In an interesting comment on the regimental commander's political savy, Murata remarked that the army's candidates could never be elected. ${ }^{24}$ In nearby Chiba Prefecture, though, the governor chose recommended candidates based on their patriotism and on their lack of previous connections with the former political parties. ${ }^{25}$

Nationally conditions greatly varied but in the prefectural recommendation committee sessions themselves there seems to have been no direct army input by the Military Affairs Bureau via the regimental commanders. However, indirectly, Reservist Association and Adults Association members serving on the Political Council branches represented the Bureau's opinion about men "suitable" as recommended candidates. A former, high ranking military police officer claims that Reservist Association recommendations in branch sessions proved decisive in "many" cases. ${ }^{26}$ Generalization about the local branch recommendation process remains difficult however since the motif was variation, not conformity.

Based on the records of the Tokyo Prefectural Council, members screened perhaps three or four times the number of possible candidates relative to available Diet seats in a particular prefecture. No direct link between the previously described police investigations of suitable candidates and prefectural council deliberations exists. In 
Tokyo, for instance, committee members considered candidates for recommendation who spanned an ideological gamut from rightist rabble rouser Akao Bin to Dōkōkai leader Hatoyama Ichirō. A benchmark was previous political experience (this in an election for new men) since 51 of the 108 men considered had been municipal or prefectural assemblymen. ${ }^{27}$

Surprises awaited the national Political Council when prefectural branches submitted their candidates. Six branches endorsed Töhökai or Dökökai members as suitable recommended candidates, even including Fukuoka Prefecture's favorite son, and Tojo's bete noir, Nakano Seigo. ${ }^{28}$ It is true that the Council accepted 14 prefectural branches' recommendations without amendment but breakdowns plagued the system exemplified by the Council's rejection of 96 men endorsed regionally by the remaining 33 branches, about one of every five recommendations.

Rectification of these differences created in turn further problems. It naturally upset branch members when the national Political Council judged 62 locally recommended political newcomers as lacking enough support to be elected and thus refused to approve their recommendations. If, conversely, a prefectural branch endorsed mainly incumbents for recommendations, it ran the risk of a local backlash. The Tochigi Prefectural Branch recommended six incumbents and provoked a "fierce reaction" to these selections by the local Adults Association's chapter leaders who perceived incumbents as pillars of the "old order" inimical to reform. In Nagano's Second Electoral District, where the branch endorsed three incumbents for the constituency's three seats, the Adults Association "exploded" in dissatisfaction against recommended candidates. Similar Adults Association resentment over prefectural recommendations flared in Yamagata and Iwate Prefectures. ${ }^{29}$

Elsewhere, indicative of the wide divergence in candidate standards, the "new men" endorsed for recommendation turned out to be from the prefectural assembly ranks which prompted allegations that their selection occurred on regional not national considerations. ${ }^{30}$ Other branches, trying to short-circuit the "old order" jiban system, recommended new men at incumbents', especially Yokudo members, expense. This happened in Kumamoto's First Constituency where members bypassed Ôasa Tadao and replaced the district's five incum- 
bents with four new men and a former Diet member. The national Political Council rejected four of these selections and awarded Ōasa a recommendation.

Another branch ploy involved nominating junior Yokudo members ("second class personalities" according to the press) instead of the former party leaders. ${ }^{31}$ In Fukuoka, for instance, the branch did recommend Yokudo members but not Katsu Masanori and a similar case occurred in Tochigi. Once again, the national Political Council reinstated the senior party man.

The candidate recommendation system exacerbated the existing political tensions. Endorsing incumbents for recommendations caused reformists to grumble and vice versa. Awarding "new men" recommendations sparked anger among incumbents who rightly felt their careers threatened. Harmony between national and regional councils proved exceptional. This merely portended more angry howls when the Political Council announced its officially recommended candidates.

Political Council headquarters finally completed its official recommendations when it publicly endorsed 466 candidates including 235 incumbents (208 Yokudō), 18 former Diet men, and 213 so-called "new men." In 10 constituencies, however, the Council named one more recommended candidate than available seats, but in 10 other districts it chose one less candidate relative to available seats. ${ }^{32}$ In the latter instances, the Council regarded incumbents like Mie's Second District Ozaki Yukio as simply too strong for any recommended candidate to dislodge.

The 306 member Yokudo lost almost 100 members (51 retirees included) but there remained a marked continuity of the former major political party leaders. ${ }^{33}$ The Council recommended all former Seiyūkai and Minseitō leaders, excluding the Dökōkai's Hatoyama Ichirō. If defunct parties' board of directors membership may be used to measure political importance, only three established former party figures, the Seiyükai's Kumagai Naota (1866-1945) and Takami Yukimichi (1880-1962) and former Minseitō official Yagi Itsurō (1863-1945) failed to receive recommendations.

Among the remaining 27 recommended incumbents, 10 came from the Giin kurabu, four from the Köa giin kai and 13 were independents. Ōta Masataka helped to secure recommendations for his 
own Giin kurabu members. The Council recommended only four of the 37 former Socialist Masses Party incumbents and no Dökōkai or Tōhōkai affiliated Dietmen.

Yokudo leaders sacrificed first and second term Diet members to insure that the Political Council recommended its own mid and upper echelon members, namely the disbanded parties' former leaders and their trusted lieutenants. These men would form the backbone of any new, post-election political party. The Political Council's lack of any substantive regional organization made such a compromise possible. ${ }^{34}$ The Council's jury-rigged prefectural branches were a stop-gap measure. As the Miyako grudgingly recognized, only compromise and cooperation with the established Diet influences could create a political power base for the war effort. ${ }^{35}$ In such a symbiotic relationship, the Council benefited from the incumbents' political expertise and regional jiban connections to conduct an orderly election campaign that would provide a favorable external appearance. Conversely, the Yokudo needed the Council's blessing to baptize its "old order" politicians with the recommendation waters of political rebirth as new order representatives.

Yokudo leaders did take care of their own. Among the 208 recommended Yokudo members, almost all had served at least three terms. A comparison of respective candidates age groups well illustrated this phenomenon. Almost $70 \%$ of recommended candidates were over 50 years of age, but only $49 \%$ of independents were over $50 .^{36}$

\begin{tabular}{|c|c|c|c|}
\hline \multicolumn{4}{|c|}{ Recommended Candidates } \\
\hline $30-40 \mathrm{ag}$ & group & & adidates \\
\hline ו" $40-50$ & & & \\
\hline $50-60 "$ & " & 193 & $"$ \\
\hline $60-70$ & " & 107 & " \\
\hline "ו & "I & 18 & " \\
\hline
\end{tabular}

Unrecommended Candidates

\begin{tabular}{|c|c|c|c|c|}
\hline \multirow{2}{*}{\multicolumn{3}{|c|}{$30-40$ age group }} & \multicolumn{2}{|c|}{73 candidates } \\
\hline & & & 241 & \\
\hline $50-60$ & " & " & 208 & " \\
\hline $60-70$ & $"$ & $"$ & 77 & $m$ \\
\hline & " & " & 15 & " \\
\hline
\end{tabular}

All recommended candidates over 70 were Yokudō members, including Machida Chūji at 80. Newspapers reflected the disappoint- 
ment over such recommendations by lamenting that the candidates' age lacked the "expected freshness" that the ballyhoo about building a new Diet seemed to have promised. The Nichi Nichi newspaper regretted that recommended candidates were older than the public expected. $^{37}$

Only a few prominent Diet figures were non-recommendation casualties. Perhaps the best known was Yokudo member Kazami Akira (1886-1961), a key promoter of Konoe's new order. The Ibaraki Prefectural Branch did recommend him, but the national Political Council vetoed the endorsement. ${ }^{38}$ Other nationally known incumbents either retired from Diet politics, like the Yokudö's Adachi Kenzō (1868-1948), or ran unsuccessfully as independents, like the Giin kurabu's Akamatsu Katsumaro, when they did not receive recommendations.

Yokudo leaders used their positions on the Political Council's national recommendation committee to turn the recommendation system into a patronage operation. So doing enabled them to extend and to enhance further their own Diet authority and personal control. Simultaneously, by withholding recommendations from freshmen and sophomore Diet members who, after all, had tried to wrest control of the Diet's management from the former party leaders in 1941, the Yokudō chiefs removed the Young Turks who briefly had threatened their powers. "New men" would be easier to deal with than proven foes.

A composite.candidate drawn from the 213 so-called "new men" probably had some connection with the IRAA or Adults Association as 158 "new men" did. However, since such membership was nonexclusive, the candidate's vocation probably was politics because 59 "new men" were prefectural or municipal assemblymen. There was one chance in six that he was a landholding "agriculturalist," but only one in 20 that he was a retired military officer. Bureaucrats like Commerce and Industry Minister Kishi Nobusuke (1896- ) and Agriculture and Forestry Minister Ino Hiroya (1891- ) did garner many recommendations. ${ }^{39}$ That 29 Political Council regional branch directors or members resigned their positions in order to become candidates and 24 of them, all new men, received recommendations suggests that plain, old fashioned connections helped in getting a recommendation. ${ }^{40}$ 
Applied to recommended candidates then, the euphemistic term "new man" really designated a candidate who had not previously stood for office in a national election. In that restrictive sense, the recommended "new men" were old wine rebottled; they were influential community leaders or prefectural and municipal assemblymen who had clear political party lineages. Council opponents interpreted such selections as political patronage and thus believed that such candidacies might be exactly like the former political party men whom they were supposed to replace. ${ }^{41}$ Typical was the reaction of the Miyako reporter who complained that the presence of so many regional property owners among the recommended candidates made politics a game only for the rich. He illustrated his point with the telling historical analogy that had the Meiji Restoration leaders been alive in 1942, they would not have been able to become recommended candidates since they came from society's lower classes. ${ }^{42}$

\section{Reactions}

Regionally, the Adults Association led the angry outburst directed against the Political Council's recommended candidates. Members opposed these selections because they represented the notorious "election-first philosophy" and made it inevitable that the Political Council recommended "old order candidates." This in turn forced Adults Association members to perform their election responsibilities under the Political Council's unreasonable orders. ${ }^{43}$

General Abe lacked the politician's touch when he candidly admitted Political Council shortcomings. Abe's mood matched the dismal rainy day as he vented his personal frustration at an April 6 press conference postmortem of the candidate recommendation results. He complained about the lack of time to complete proper election preparations, having only eight days from branch formation to candidate recommendation. Furthermore, potential candidates were unevenly distributed, some places having a surplus and others a scarcity of suitable political talent. The latter condition forced the Council to endorse unsatisfactory candidates. On the positive side, the Council had tried its best and henceforth it would help inexperienced "new men" it had recommended to get elected. ${ }^{44}$ What Abe meant was 
that the Political Council failed to achieve its homefront unity objectives.

Although the Yokudo dominated the recommendation process, the remaining 231 Diet seats represented a rich prize. No single group in Japan believed themselves more deserving of all of these recommendations than reform right wingers. They overestimated their strength based on their conviction that they were the prime movers of the Pacific War and the electorate would repay them at the ballot box. Although rightists apparently never tired of streetcorner harangues, seemingly no one was listening since collectively rightists had witnessed a decline in popular support for their programs and they believed that the Political Council and the Tojo government were ignoring them. ${ }^{45}$ That last assumption was among their most accurate.

Reform and traditional factions fared poorly in Political Council deliberations. The Political Council recommended only 28 reform rightists but the police classified only two of nine incumbents and 11 of 19 "new men" as activists, the remainder being nominally rightist. Most prominent among the "new men" were Hashimoto Kingōoo and Shiratori Toshio (1887-1949), the retired diplomat who had been a leading proponent of an Axis alliance.

Still, it perhaps was better to be ignored than to be banned. That March the Home Minister, based on the December laws, did refuse the Rikken yöseikai permission for political status because:

The Nichiren religio-political organization's avowed aim being a political dictatorship by 1947 profanes respect for kokutai. Under total war it has an evil influence on the public's ideas and the association is antinational policy in its speech and activities. ${ }^{46}$

The organization's size, 650 branches with 200,000 members, probably concerned Tojo and the Home Ministry more than its philosophy. Nevertheless, the Home Ministry did allow Society members to stand for election provided they did so as individuals and not as Rikken yōseikai members. Rikken yōseikai Director Tanaka Sawaji (18871955) promptly took advantage of that loophole in the Police Security Law to run 37 candidates, ostensibly as unaffiliated independents.

Traditional rightist associations never displayed much enthusiasm for the election since they regarded elections as merely Western corruptions that obstructed the true manifestation of direct imperial 
rule. $^{47}$ Police did identify, however, 29 recommended traditional rightists, but described 17 incumbents or former Diet members as just nominal rightists. ${ }^{48}$ Political Council member Ida Iwakusa, an official of the anti-communist Mizuho kurabu (Japan Club), secured recommendations for a politically obscure quartet of his Club's members. Ida also worked with Ōta Kōzō to obtain recommendations for three Kokusai hankyö renmei (International Anti-Communist League) members, including retired army Lieutenant General Shioden Nobutaka (1879-1962), the notorious anti-Semite. ${ }^{49}$

The reform and traditional right's failure to establish political respectability made their candidates unacceptable to the Political Council. Popular sentiment regarded the right as irresponsible and outside the electoral process, especially after rightist violence during the preceding decade. Rightists themselves believed that their rejection was due to the former party leaders' influence on the Political Council. Convinced that the electorate would support them, 168 reform rightists still stood for election, an increase of 130 candidates over $1937 .^{50}$ About 60\% came from the Töhōkai (45), Rikken yōseikai (37), and Sekiseikai (17). The remaining 69 candidates represented a hodgepodge of insignificant rightist splinter groups. Police analysts dismissed the 20 traditional rightist independents as inactive rightist sympathizers. ${ }^{51}$ If the reform rightists, hoping to capitalize on wartime emotions, stumbled over each other hurrying to the campaign trail, a majority of non-recommended incumbents opted not to run for reelection.

The Dókókai and the former Socialist Masses Party members' inability to secure recommendations discouraged them from again standing for office. Seven Dökökai members retired and two others defected from the party in hopes of receiving Political Council recommendations although neither $\operatorname{did}^{52}$ The party endorsed no "new men" and only 28 of its 37 incumbents ran for re-election. Similarly, only 40 former Socialist Masses Party members became candidates as compared to 66 in 1937. Leading figures of the disbanded party like Miwa Jyūsō and Asanuma Inejirō (1898-1960) decided not to run for re-election. Ironically, the police evaluated both men as "suitable candidates" most likely because of Miwa's IRAA office and Asanuma's 
Diet vote supporting Saito Takao's (1870-1949) censure for a 1940 Diet speech that criticized the Japanese army's China policy. ${ }^{53}$

\section{Candidate Motivations}

While a majority of non-recommended incumbents decided not to seek re-election, just the opposite held true among independents. The entry of 384 unaffiliated candidates into the election race was a genuine surprise but one that seemed to negate the Political Council's raison d'etre. Without political parties to restrict candidacies, political commentators expected the Council to prevent "riff-raff candidates" from disrupting the election. ${ }^{54}$ Legally, however, the Council could not prohibit qualified persons from standing for election and ultimately a record number of 1,079 candidates contested the Diet's 466 seats in 1942. ${ }^{55}$ The Home Ministry labeled 645 of these "new men," with 213 recommended candidates, 39 Töhökai, and nine from other reform rightist political parties (Kokusui taishutō, five, Dai Nippontō (Great Japan Party), three, and Kenkokukai, one).

The Political Council inhibited incumbents but apparently few others since 418 men filed their candidacies on April 4, the first day to do so, compared to just 63 at the comparable point during the 1937 election. Their numbers bewildered political commentators who incorrectly predicted that a considerable number of these new, independent candidates would quit the campaign by the April 19 deadline for filing a candidacy or for withdrawing from the campaign without forfeiture of the required 2,000 yen election bond. ${ }^{56}$ That prediction ranked with those of a self-styled diviner who told the Peers Club in January that there would be an armistice by 1944 and no problems for Prime Minister Tojo.

These independents, while younger than their recommended opponents, were not necessarily political newcomers since 106 came from prefectural assembly ranks. A complete occupational candidate breakdown was lacking, but among all independents there were more writers (56 to 12 recommended), newspapermen (26 to 12), and lawyers (76 to 21$)$ than among recommended candidates. Conversely, more recommended candidates had IRAA affiliations (247 to 108) than independents. ${ }^{57}$ Candidate motivations were as diverse as their backgrounds. 
According to General Abe, the favorable public reaction to the Tojo cabinet's pre-election campaign rhetoric generated the motivation for a record number of new men to stand for office. ${ }^{58}$ Prime Minister Tojo's publicly expressed wish for a fresh, new Diet indicated an attitude of respect for the Diet and that in turn encouraged candidacies. ${ }^{59}$ So-called new men reasoned that, as political newcomers untainted by the old political order's abuses, their election would cleanse the Diet reputation stigmatized by the professional politicians.

Political parties' absence also enhanced newcomers' chances to become viable candidates because parties could no longer monopolize the election process by their stranglehold on the candidate nomination system. $^{60}$ Ideally, their nonexistence precluded deals on jiban areas and it was even possible, in theory, to destroy the hated jiban web. Such reformist sentiments bore the imprint of Prince Konoe's new order movement that had politicized the younger generation. Altruism, expressed as a desire for political reform, provided a strong motivation for becoming a candidate. ${ }^{61}$

The concept of Diet renovation by reformist newcomers also swelled candidate ranks. It was the first general election in five years and probably created a feeling among newcomers that this was their best, and perhaps only, chance for election to the Diet. The extraordinary length of time between general elections whetted the political appetites of these lean and hungry newcomers and made them unusually eager to run for office, although their appetites usually proved better than their digestion. Reform rightists exemplified those who perceived the Greater East Asia War as justifying their claims for just rewards from the Japanese political system. Moreover, the rhetorical emphasis on rebuilding East Asia and on the war entering a new, constructive stage seemed to imbue the election with a historic significance that helped to attract candidates who wanted to partake in that glorious enterprise.

All candidates did not, naturally, run for altruistic motives. Among independent candidates, and definitely among Töhökai, Rikken yösei$k a i$, and reform right splinter parties, men ran for office because of their deep dissatisfaction with the Political Council's candidate recommendation system. On a more visceral level, Akao Bin said that 
the election campaign provided him with a public forum that facilitated his criticism of the Tojo government. ${ }^{62}$

Traditional Japanese election practices, still in evidence today, also increased candidate totals. Perhaps as many as ten percent of all candidates realized that they had no chance whatsoever of being elected, but ran anyway just to gain the public exposure the election campaign provided. By making themselves known to the voters, they had a headstart in the upcoming municipal elections, their real electoral goal. ${ }^{63}$ The so-called "single flag groups" (ichi hata gumi) candidates also had very restricted interests and planned to devote their campaigns to limited, pragmatic, future goals. More of such types than usual appeared in 1942 because the wartime inflation made the 2,000 yen election bond a less prohibitive financial barrier than it had been in past elections. It was for such candidates, who might correctly be described as "power aspirants," cheap advertising. ${ }^{64}$

Finally, the government's attitude toward the record candidate numbers was ambiguous since so many candidates might be liable to provoke disorder, proving difficult to control. If, however, candidates did not disrupt the election or incite public disorder, the Tojo cabinet probably welcomed the additional candidacies. More candidates meant more opportunities to disseminate official policy and more chances to involve all segments of society in a didactic election campaign to promote homefront unity for the war effort.

The record candidate turnover indicates, in a quantitative manner, that the Diet was still regarded as an effective political institution and that a Diet seat was a significant position. If potential candidates believed otherwise, they would, it seems, shun the burden of time, energy, and money that was necessary to compete successfully for a Diet seat. A blend of idealism, that they could do better than their predecessors, and realism, that only within the existing political structure could they implement their ideas, permeated newcomers' ranks. Professional politicians may have been held in low esteem, but the institution of the Diet was not. 


\section{Chapter V \\ The 1942 Election Campaign: An Overview}

\section{Election Promotion}

Total warfare failed to disrupt traditional Japanese election campaigning techniques. Campaign rally, supply, and topic restrictions however did seem to dampen public enthusiasm for the candidates. Voters found it difficult to identify with an election campaign that lacked the free swinging competition characteristic of political party elections. They missed the campaign's accustomed holiday atmosphere. ${ }^{1}$

Superficially, one could notice election preparations as streetcars and city buses dashed about Tokyo decorated with reminders to vote. When taking tickets, bus girls politely told passengers to be sure to vote. $^{2}$ Enlightenment campaign rallies dotted the city and, despite a restricted male suffrage, women's groups occupied streetcorners urging passers-by to vote. School children were even mobilized to bring home classroom explanations about the campaign. Huge election message streamers bedecked IRAA Headquarters and even the Metropolitan Police Board's forboding red turret. The staid Home Ministry building itself unfurled a massive banner reading "Your Vote Builds Greater East Asia." That unimaginative slogan symbolized the election campaign's problem.

The Tojo cabinet and the Home Ministry apparently believed that quantity could compensate for quality and consequently deluged voters with a flood of campaign lectures, pamphlets, radio broadcasts, banners, posters, and newspaper stories. The enlightenment campaign itself seemed like a brilliant innovation for it legally mobilized public associations like the IRAA and the Adults Association for essentially political ends. However, although the enlightenment campaign by starting in early March extended didactic campaigning, it pre-empted the election campaign that opened on April 4. This early start probably overtaxed popular interest in the campaign because it proved impossible to sustain such high pitched enthusiasm for two months. Like a slowly developing kabuki drama, stretching out the election campaign 
perhaps appealed to election connoisseurs but left the layman a bit bored.

Too many other distractions tempted the public for election rhetoric to monopolize its attention. War news filled several newspaper columns every day. The day lacking some spectacular military feat offered the Information Bureau its chance to stir up chauvinism by releasing individual heroic exploits. For instance, in early April a well coordinated propaganda campaign capitalized on the exploits of the midget submarine crews, the so-called Pearl Harbor war gods, conveniently omitting that a United States prisoner of war camp at present rudely enshrined one "god." Furthermore, in the spring of 1942 , it was business as usual on the homefront as movies, kabuki theater, concert recitals, and operas drew packed houses. More immediate concerns also consumed public time and patience exemplified by more people willing to line up to buy wafer-thin rice crackers from a streetcorner vendor than to hear an election speech. ${ }^{3}$ Then, of course, the annual outings to view the springtime cherry blossoms drew vast crowds to public parks and away from election and enlightenment campaigns. Life was maddeningly normal.

IRAA and Adults Association efforts to make voters aware of the election had mixed results. Both organizations headquarters' staff members originally tried to combine their forces for the enlightenment campaign. A Committee to Accomplish a Yokusan Election (Yokusan senkyo kantetsu undō ïnkai) did sponsor a mass meeting at Tokyo's Hibiya Park in mid-March, although light drizzle held down attendance. ${ }^{4}$ Regionally, a lack of cooperation characterized the two associations as each implemented its local level campaign as it saw fit, forming joint committees in only 16 of 47 prefectures. $^{5}$

The IRAA's election platform conformed identically with the previously announced cabinet election plans. Organizationally, the IRAA established eight regional campaign districts where throughout March IRAA national representatives provided campaign direction for regional branches. ${ }^{6}$ Its campaign tried to mobilize voters by appealing to their sense of duty to vote and emphasizing that the voters could help to eradicate "foreign ideas" like individualism, liberalism, and democracy. "Those we want to run" not "Those who want to run" became the IRAA's slogan and that probably represented its 
most lasting contribution to the 1942 campaign. The former candidates were those of national outlook as opposed to the latter self-seeking opportunists. Identifiable characteristics of such "unsuitable candidates" were a lack of commitment to Japan's immutable national policy, cynicism about national renovation, and possession of jiban built on favoritism, money, or abuses of public office. ${ }^{7}$

Plays, movies, lectures, pamphlets, and neighborhood association billboard posters spread the IRAA's enlightenment campaign and it sponsored over 300 meetings nationally. ${ }^{8}$ In late February, the IRAA had requested the public to submit election slogans and by March 3 claimed to have received about 100,000 entries. Additionally, in late March, it called on all reservists and local town and village organizations to promote the "general election's ethical elevation," but response lagged as only 10 prefectures did so. ${ }^{9}$

Press reports described the "enlightenment campaign" as inactive in Aomori, weak in Hiroshima, and, more ominously, poor attendance marked Miyagi's campaign as did friction causing "rumors" between its IRAA and Adults Association branches. ${ }^{10}$ Throughout March, an enlightenment campaign featuring movies and political drama toured Fukuoka Prefecture, but, in mid-April, reporters noticed that no coordinated campaign had developed there. ${ }^{11}$ In Hokkaidō, Chiba, and Tochigi, the public "was not dancing to the enlightenment campaign piper's tune."12

The major cities were, at best, lukewarm about "enlightenment." In Kobe the lack of campaign atmosphere mystified reporters. Osaka observed little enlightenment activity which was better than the "nonexistent enlightenment campaign" in Nagoya and Yokohama. Despite IRAA lectures, dramas, and movies to promote the didactic campaign, Kyoto's political consciousness was "abominable." Similar events in Tokyo Prefecture also failed to generate much enthusiasm for the election. ${ }^{13}$

There were some successes. Aiichi Prefecture, outside Nagoya City, reported an active IRAA effort, and, in neighboring Gifu public lectures drummed home the election's importance. Gunma's IRAA branch staged plays, movies, and traditional Japanese music concerts to attract audiences for enlightenment lectures. It also combined business with politics by conducting war bond sales at enlightenment 
rallies with excellent results, especially in the remoter districts. ${ }^{14}$ Likewise, in Iwate Prefecture, the ever popular "picture story shows" (kami shibai) were mobilized for the election effort. ${ }^{15}$

Like its parent body, the IRAA's enlightenment campaign was mediocre, and ultimately unable to accomplish its goals. The enlightenment and subsequent election campaigns highlighted the IRAA's decline compared to the Adults Association ascent.

The war encouraged the Adults Association to launch its boisterous campaign. Its local chapter leaders perceived the wartime election as their chance to smash the regional political status quo exemplified by the incumbent politician's jiban. In those rural areas where it enjoyed traditional backing, the Adults Association exhibited the ability to promote an animated campaign, but it also revealed a tendency to bully opponents into silence.

In Nagano and Gunma Prefectures, the Adults Association conducted a lively enlightenment campaign and in Nara and Kanagawa Prefectures openly campaigned against incumbents. It probably was strongest and most active in Kagoshima where the worst campaign interference excesses occurred. The association dominated local enlightenment campaigns and ran roughshod over its IRAA counterparts. ${ }^{16}$

As self-styled vanguards of reform, Adults Association members inevitably clashed openly with the Political Council over the latter's candidate recommendations. Prefectural units ignored or flaunted the Council's selections for recommended candidates. In Shimane Prefecture, for instance, the Adults Association vice-director refused to support the Council's recommended candidates. Instead he ran himself as an independent backed by the association, thus splitting the association and the Political Council during the election campaign. The Political Council recommended too many incumbents for the Aomori Adults Association so they refused to support recommended candidates. Likewise, in Fukushima Prefecture, the Adults Association quarreled with the Council because it failed to recommend "new men" as candidates and association members even asserted that they had the right to support their own candidates. ${ }^{17}$ While such cases of outright defiance were probably exceptional, the Adults Association 
plainly used its regional advantages as much to advance its own cause as it used them to promote the yokusan election.

Adults Association election related activity was much more dynamic in the countryside than in the large cities. Even in the hinterlands though, it failed to produce a uniform "enlightenment" movement, notable failures occurring in Saitama and Chiba Prefectures. ${ }^{18}$ During the actual election campaign, Adults Association members disrupted independent and even certain recommended candidates' campaign rallies, resulting in numerous allegations of illegal campaign interference being lodged against it.

\section{The Political Council's Campaign}

The Political Council devoted its main efforts to helping its 213 recommended political newcomers' election campaigns. The fact that these new men were unfamiliar with national level campaigning prompted the Council to explain its well organized and disciplined campaign overview in a primer distributed to all candidates. Starting with the very basics, the primer instructed candidates on how to file their $k \bar{o} h \bar{o}$, a critical matter for the candidate had to file one with the election authorities in his district and it constituted his platform as well as introducing the newcomer to the voting public. General Abe and prefectural Council branch leaders endorsed all testimonials. Additionally, both prefectural and the national Council branches mailed $3,220,000$ postcards to voters encouraging them to choose recommended candidates on election day. Each branch sent at least 5,000 cards per candidate and in the 90 districts where recommended candidates seemed on the borderline of defeat or victory, 10,000 additional cards were mailed to voters. This latter mailing occurred in the final, crucial election stage and the Council specifically designed it to impress the electorate with the Council's organization and national coordination. On the negative side, it buried prospective voters in a blizzard of junk mail and election prose. It was again quantity replacing quality, political overkill. Even as avid a student of political affairs as Meiji University professor Yabe Teiji (1902-1967) balked at reading the campaign literature for all 23 candidates in Tokyo's fifth ward. ${ }^{19}$

As for the actual electioneering, Council members, including Abe, Gotō Fumio, Suetsugu Nobumasa, and Nagai Ryūtarō made phono- 
graph recordings that recommended candidates in turn could use at their campaign rallies. The records' themes ranged from the necessity of Diet renovation to Nagai's polemic calling on all Asians to unite to smash Britain and America. Every recommended candidate also received a political handbook that covered election campaigning techniques with homey advice on topics like how to organize election committees, to select campaign rally locations, or to endorse candidates.

The Council planned the election campaign in three phases. Phase one would fix the candidate in the voters' minds through a series of district wide campaign rallies and endorsements. Next the candidate would promote his election by campaigning district wide for ten days. Phase three, coinciding with the campaign's final days was considered the most important so the candidate had to concentrate his campaign rallies in the district's key precincts. Recommended candidates anticipating close races with independent rivals in severely contested elections had to avoid mutual destruction by uniting with other recommended candidates against the independents, a proviso strikingly similar to the former parties' jiban deals. Council branch units also assessed independent candidates' campaigns and reported their findings to recommended candidates' campaign directors. They in turn adapted their candidates' campaign to exploit opponents' weaknesses. If confronted by a superior independent candidate, recommended ones should "invade" the independent's jiban by using local community leaders as speakers at their campaign rallies. ${ }^{20}$ It may have been an election for new men, but the electioneering techniques were as old as Japan's first general election.

Each recommended candidate allegedly received at least 5,000 and perhaps more than 10,000 yen for their campaign expenses from a special secret army fund. Details of this secret fund (kimitsukin) remainded clouded. Hashimoto Seinosuke claimed that Chief Cabinet Secretary Hoshino Naoki disbursed the funds while another account credits the prefectural Home Ministry general affairs director with distributing the money. The alleged "slush fund" may have totaled 10 million yen, coincidentally the amount of a similar election slush fund that the Seiyūkai Party leaders used to bankroll their 1928 candidates to the tune of 30,000 to 50,000 yen each. ${ }^{21}$ 
Recommended candidates, probably because of their advantages, began their campaigns tardily and from April 4 to 10 left the field to their independent opponents. Weather turned against the Council as wind and rain held down attendance at an April 10 mass rally at Tokyo's Hibiya Park. After such a lackadaisical start, the recommended candidates spent the next two weeks making up lost ground. On April 12 polls showed about $60 \%$ of recommended candidates (mainly incumbents) would be elected but a week later that figure reached $75 \%$, or about 350 candidates. General Abe managed to avoid any political miscues by contenting himself to remark on the decided turn for the better that the campaign had taken. ${ }^{22}$ Polls confirmed the strength of recommended incumbents and former Diet members with 182 winning and 35 of the other 59 still having good prospects for election. Among new men, however, only 40 clearly led their independent rivals with 130 contested races too close to call. ${ }^{23}$

The campaign rally constituted the Political Council's main means of assisting recommended newcomers' campaigns. During 19 days in April, the Council sponsored approximately 460 major rallies and 11,000 rallies of all kinds throughout Japan. The majority of rallies occurred during the campaign's final ten days when the Council staged a political blitzkreig against independent opponents in a nationally coordinated finale. General Abe did his part by sending telegrams to all branch chiefs and recommended candidates praising their efforts and assuring them of his conviction of inevitable victory. ${ }^{24}$

Benefiting from central guidance and lavish campaign funds, recommended candidates' greatest advantage was the coordination function provided by the national Council. All other political organizations lacked that capacity and, indeed, parties like the Dōkokai or public associations like the Rikken yöseikai did not enter a national candidate slate. Locally, the Council still had to cooperate with regional influences like accommodating incumbents who became recommended candidates, prefectural governors' desires, and local Adults Association and IRAA ambitions.

Regional influences bent, but did not break, under national pressure from the Political Council and the Tojo government. The Council itself never penetrated the local political arena, rather wisely leaving that complex and sensitive operation to its prefectural branches staffed 
Major Campaign Rallies for Recommended Candidates

Location Date Speaker(s)

\begin{tabular}{|c|c|c|}
\hline Tokyo & $4-10-42$ & Abe Nobuyuki, Gōdo Takuo, Yamazaki Tatsunosuke \\
\hline Tokyo & $4-28-42$ & Ōta Masataka, Yoshida Shigeru, Shimomura Hiroshi \\
\hline Sapporo & $4-12-42$ & Ōta Kōzō \\
\hline Aomori & $4-17-42$ & \\
\hline Narioka & $4-14-42$ & Ōta Kōzō \\
\hline Sendai & $4-12-42$ & \\
\hline Akita & $4-15-42$ & \\
\hline Yamagata & $4-13-42$ & \\
\hline Fukushima & $4-16-42$ & Ōta Kōzō \\
\hline Mito & $4-15-42$ & \\
\hline Ushinomiya & $4-15-42$ & \\
\hline Maebashi & $4-17-42$ & \\
\hline Saitama & $4-20-42$ & \\
\hline Chiba & $4-14-42$ & Ida Iwakusa \\
\hline Yokohama & $4-12-42$ & Fujiyama Aiichirō \\
\hline Kofu & $4-17-42$ & Gōdo Takuo \\
\hline Nagano & $4-14-42$ & \\
\hline Shizuoka & $4-11-42$ & Tanaka Tokichi \\
\hline Nagoya & $4-13-42$ & Nagai Ryutarō \\
\hline Niigata & $4-16-42$ & Taki Masanori \\
\hline Toyama & $4-14-42$ & Taki Masanori \\
\hline Kanezawa & $4-12-42$ & Taki Masanori \\
\hline Fukui & $4-11-42$ & Taki Masanori \\
\hline Gifu & $4-15-42$ & \\
\hline Tsu & $4-17-42$ & Ida Iwakusa \\
\hline Otsu & $4-14-42$ & \\
\hline Kyoto & 4-15-42 & Gotō Fumio \\
\hline Osaka & $4-12-42$ & Abe, Nagai \\
\hline Nara & $4-15-42$ & \\
\hline Wakayama & $4-16-42$ & Ōta Masataka \\
\hline Kobe & $4-15-42$ & Nagai \\
\hline Shimane & $4-13-42$ & Ōta Kōzō \\
\hline Matsue & $4-14-42$ & Ōta Kōzō \\
\hline Okayama & $4-18-42$ & \\
\hline Hiroshima & $4-18-42$ & Ōta Kōzō \\
\hline Yamaguchi & $4-16-42$ & \\
\hline Tokushima & 4-13-42 & \\
\hline Takamatsu & $4-15-42$ & \\
\hline Matsuyama & $4-17-42$ & \\
\hline Kochi & $4-14-42$ & \\
\hline Fukuoka & $4-19-42$ & Yamazaki \\
\hline Saga & $4-14-42$ & \\
\hline Nagasaki & $4-15-42$ & Yamazaki \\
\hline Kumamoto & $4-17-42$ & Gotō Fumio \\
\hline Oita & $4-13-42$ & \\
\hline Miyazaki & $4-15-42$ & \\
\hline Kagoshima & $4-17-42$ & Yamazaki \\
\hline
\end{tabular}

Source: Kiroku, 275-282. 
by local community leaders. Despite rhetoric about "new men" with national, not sectional, outlooks, even recommended candidates without significant local support and cooperation, the traditional election criteria, could not expect easy victories. Against an entrenched political jiban, a recommendation and Council backing did not guarantee success as testified to by the defeat of 44 recommended newcomers. Neither did an incumbent's recommendation insure re-election as demonstrated by the defeat of 35 recommended incumbents (33 Yokudo). Council opponents seriously contested the election, something unheard of in a show election.

\section{Non-Recommended Candidates}

The earliest election planning committees considered the Dōkōkai the potential anti-government party. ${ }^{25}$ Its February stand against the recommendation system and Andō Masazumi's March Diet interpellation confirmed the previous police estimates that the Dókokai was intrinsically anti-government. Identified in the public mind as "liberal," the Dökōkai endorsed no "new men" as candidates, making it easy to stigmatize it as a prop for the old order. Internal factionalism added to the party's handicaps. Nevertheless, the 28 Dōkōkai incumbents standing for re-election refused to acquiesce meekly to official pressure and to become shills for national unity in a didactic election campaign. Criticism of domestic policy, especially the recommendation system, characterized the party's campaign oratory. The Dōkōkai unreservedly supported the war effort, but it disagreed with the Tojo cabinet's homefront policies. ${ }^{26}$

Ozaki Yukio, unquestionably the most unabashed government critic, personified this Dōkōkai position. His open letter to Tojo was one example. In campaign speeches, Ozaki's forte, he attacked the recommendation system as being the equivalent of a government appointment to the Diet and, consequently, a denial of the Lower House's representative function. ${ }^{27}$ His $k \bar{o} h \bar{o}$, reduced to an incomprehensible jumble as the police censored it in 27 places, was yet another example of his stubborn determination to resist vigorously government attempts to manipulate the election. Ozaki brazenly denounced any government interference in independent candidates' election campaigns and wrote that liberalism's detractors in fact criticized the 
Meiji Emperor's greatest work, the constitution. After all, he argued, no matter how long the war lasted, the nation and the constitution would exist in perpetuity and they had to be safeguarded.

Ozaki could appeal to the constitution's authority for that sacrosanct document still commanded the respect of all segments of Japanese society as a gift publicly bestowed on loyal subjects by the revered Emperor Meiji. War had not altered that fact. Instead, throughout the election and throughout the war, institutionalized law, ultimately embodied in the constitution, remained intact. Both the Tojo government and its opponents like Ozaki recognized constitutional provisions, although applying different interpretations to them. ${ }^{28}$ Government condoned election excesses in previous elections and in 1942 no more nullified the Meiji Constitution than similar excesses in the United States might void that constitution.

Generally, the Dókokai suffered from a lack of publicity in newspapers and popular magazines. These treated Dōkokkai candidates, with a few notable exceptions, as an indistinct part of the independent candidates' generic whole. The attention the party did receive was usually negative as the press criticized its failure to coordinate a campaign. Dökökai standard bearers really ran as individuals and perhaps 16 or 17 candidates could expect to be elected by virtue of their strong, personal jiban connections. ${ }^{29}$ Otherwise political observers scorned the party's inability to arouse any feeling among the electorate. ${ }^{30}$ This latter defect, in part, was due to official interference directed against Dōkōkai candidates.

Interference was a recurrent phenomenon in prewar Japanese electoral politics. It might be either "negative" or "positive" in application. The former meant that the police strictly enforced the minutest regulations against one faction or party, but were lax to the point of condoning election violations by their opponents. The latter type involved the direct intervention of police or local government authorities in a campaign for the advantage of specific candidates. Examples of such activity to affect decisively the election were campaign rally suspension or obstruction, voter intimidation, vote solicitation, campaign disruption, or arresting candidates.

Dōkokkai candidates had to campaign under the close scrutiny of the police who allegedly ignored election infringements committed 
by Dōkōkai opponents; in Kagoshima, Nagasaki, Kyoto, and Niigata, police reportedly ignored recommended candidates' violations at campaign rallies and those same candidates' campaign workers' violations. $^{31}$ In Toyama, police took no action against a recommended candidate who gave away free sake at his campaign office throughout the electioneering period. ${ }^{32}$ The candidate had enough sense to stop temporarily this spirit flow so that grateful, if hungover, voters might repay him at the polls. Voters, in fact, did elect him, perhaps anticipating his victory party.

As for "positive interference," prefectural governors in Gunma and Kagoshima allegedly instructed community leaders and public employees for whom to vote; the Wakayama governor ordered Civilian Guard (Keibódan) units to obstruct independents' campaigns and to solicit votes for recommended candidates; in Nagano, Gunma, Toyama, Yamagata, Kumamoto, and Nagasaki the police canvassed for votes for recommended candidates. The latter incensed one voter so much that he nullified his ballot by hurriedly scrawling, "The Police are recommended candidates' campaigners!" 33

The most sensational 1942 example of "positive interference," however, was Ozaki Yukio's arrest for alleged lèse majesté. Secure in his Mie jiban, Ozaki came to Tokyo to stump for Third District Dōkōkai candidate Tagawa Daikichirō's campaign. On April 12 and 13, speaking before crowds of around 400 persons, Ozaki denounced the recommendation system, exhorted his audience to preserve the constitution, and, using the Chinese proverb that the third generation squanders the inheritance, recalled that the present Showa Emperor was the third generation since the Meiji Restoration and thus it required extra vigilance to defend constitutional government. Police attending the rally made stenographic copies of his speeches, and, after two unheeded "Cautions" during the April 13 rally, ordered the meeting suspended. Afterwards, Ozaki returned to Mie but the Thought Police subsequently ordered him to appear in Tokyo to answer lèse majesté charges. ${ }^{34}$ Released while the prosecutors prepared their case, Ozaki returned to Mie to campaign successfully for re-election despite police attempts to disrupt his campaign by arresting him.

Against such interference that was a continuing fact of Japanese political life, the Dōkókai countered with joint assistance tactics. A 
candidate with a strong jiban like Hatoyama or Ozaki would campaign in a weaker candidate's district to try to stimulate voter support for that candidate. Indeed, Ozaki was doing just that when the alleged lèse majesté incident occurred. With only 28 candidates, however, the party could not mount a national campaign because its scattered constituencies even made it difficult for the Dökökai to assist its candidates in relatively remote areas like Toyama or Kochi Prefectures. Eleven of the 28 Dōkókai candidates stood in three large cities (Tokyo-Osaka-Kyoto) and in Ozaki's Mie stronghold. Transportation and geographic proximity in these areas made joint assistance feasible.

Despite police, IRAA, and Adults Association interference, the Dökökai never abandoned its campaign of criticizing the Tojo cabinet. After the election, Dōkōkai candidates who believed that their campaigns had been victimized by interference used the law courts for recourse. No physical abuses of any candidate or his supporters, to my knowledge, occurred. Verbal threats, intimidation, and arrests did occur, but, if evidence was lacking, the police had no choice but to release those arrested. Such actions did, as intended, seriously disrupt candidates' campaigns, but legal appeals existed for plaintiffs. While interference was severe, it was not unprecedented. Elections being imperfect phenomena, candidates' and government authorities' abuses traditionally recurred. In that context, the 1942 general election was a typical prewar Japanese style election in which the government employed its police and administrative powers, as it had done on similar occasions in the past, to try to affect decisively the election results.

As the Dōkōkai challenged Tojo from a "liberal" position, Japanese rightists challenged him from a nationalist platform. The reform right probably was the single most disruptive element during the 1942 election. Far from cooperating in a national unity show election, internecine warfare even characterized the internal relations of reform rightists with their parent organizations.

\section{The Right Wing Campaigns}

Simmering with righteous indignation over the Political Council's recommended candidates, these self-proclaimed advocates of "national unity in wartime," faced a fundamental dilemma. If they remained 
silent, their actions might be interpreted as support for all government policies; but, if they openly criticized the election, they might disrupt national unity and thereby provide ammunition for anti-Japanese propaganda. When reform rightist leaders vehemently censured the government, their rank and file became uneasy and often sided with the government against their own party's official platform. Conversely, passive acceptance of government policies might result in a particular organization's atrophy.

Tōhōkai members, for example, split over Director Nakano's antigovernment election line. The Yamaguchi incumbent left the party's ranks because he feared that Nakano's tactics would divide the electorate. Divisions over election policy also occurred in the Töhökai's Hiroshima branch, and, in Gunma, popular reaction against the local party's organization caused ten branch directorate members to quit. Party members openly denounced Nakano for using the party to advance his own selfish interests and for his uncompromising hard line, anti-government campaign. ${ }^{35}$

Hashimoto Kingorō faced a similar rebellion from below. His Sekiseikai, already bitterly divided over the candidates chosen from among the membership, splintered further because of the "rampant dissatisfaction" over Hashimoto's consuming interest in getting elected. The police wrote off the party in June for it had "lapsed into political and ideological morbidity." ${ }^{36}$ Similar charges of using members to advance personal ambitions were leveled at Dai Nippontō Director Sasaki Itsuchō (1909- ) and against the Kokusuito's Director Sasagawa who, members felt, cooperated too intimately with former party men in order to get elected. ${ }^{37}$ Dissatisfaction characterized the Tóa renmei dōshikai membership because Director Ishiwara Kanji refused to play an active role in the election campaign. ${ }^{38}$

The entire right wing's disruptive role concerned the government. Traditional rightists generally were extremely negative towards the election. The Dai Nippon Seisantō (Great Japan Production Party) opted "to kill the election by silence (mokusatsu)," while the Jikishin dōjo (Sincerity School) asserted that elections in wartime should best be avoided. The Mizuho kurabu was schizophrenic, simultaneously supporting its members who were recommended, but otherwise criti- 
cizing the election as meaningless and denouncing former party members running for re-election. ${ }^{39}$

Radical rightists participated in the election for they believed that the public's anti-government, anti-election attitude would cause election defeat for the Tojo cabinet. They assumed that the cabinet would have to take responsibility for such a defeat and, in early May, the ensuing political disorder would catapult rightists into a national reform cabinet to conduct national renovation. ${ }^{40}$ Based on political preconceptions grounded in wishful thinking, reform rightists ultimately decided to oppose the government so that they might capitalize on the anticipated post-election confusion.

The Tōhōkai, led by Nakano's leapfrogging national campaign in support of Töhōkai endorsed candidates, concentrated on a speaking campaign that denounced a government controlled economy, attacked bureaucratic politics, and rebuked the Political Council. ${ }^{41}$ The Ikken kinnō undō (One Prefecture Loyalist Movement) switched horses in midstream by leaving its inactive posture in favor of making scurrilous attacks on incumbents, the Tojo government, and the Political Council. Though barred legally from participating in the election as an association, the Rikken yoseikai entered 37 candidates as individuals, all of whom "coincidentally" endorsed Director Tanaka's castigation of the "government plot" to prohibit the organization from campaigning as a political association. The Ködó renmei continued its hysterical verbal barrage against the zaibatsu, the former party leaders, and former party members. Akao Bin drew surprising middle class support in Tokyo for his anti-Tojo election campaign. A Kyushu-based reform rightist group even threatened to carry out a Shōwa Restoration by illegal means. ${ }^{42}$

The Japanese right wing did not cooperate with the Tojo cabinet's didactic election plans. There is no evidence of sympathy between "rightists" and "militarists," let alone rightist assistance in building a military dictatorship. ${ }^{43}$ Even outwardly rightists scorned Tojo. The police continued their close surveillance of rightist groups whose activities during the election campaign only reinforced Tojo's perceptions of the right's dangerous and irresponsible nature. ${ }^{44}$ 


\section{The Dullest Campaign}

Tsukui Tatsuo (1901- ), the right-wing publicist, summarized the contemporary political consensus when he wrote that the election campaign rallies were so dull, there were many rallies where a candidate's campaign workers and speakers actually outnumbered his audience. ${ }^{45}$ There were four reasons for this most uncharacteristic Japanese election campaign sluggishness. First, according to the government, the public confidence in recommended candidates made it unnecessary for them to attend campaign rallies. Second, election speeches became hackneyed and stereotyped, lacking any special flare or voter appeal. Third, the electorate was too preoccupied with its war-related work to spend its rare free time attending campaign rallies. Fourth, the electorate missed the competition representative of the political party election and accompanying festival atmosphere that had in the past stimulated interest. ${ }^{46}$

In large Japanese cities, the campaign keynote was apathy. Commentators attributed Tokyo's dull campaign and lukewarm voter response to the failure of "new men" to materialize to meet voter expectations. ${ }^{47}$ Referring to the "surprising emptiness of the campaign rallies," a reporter noted that a Kobe candidate's turnout of 300 was "completely extraordinary." He ascribed the indifference to a surplus of rallies, 60 to 70 opening daily in Kobe, Kyoto, and Osaka, that spread the available audience too thin. Dull campaign rally speeches contributed to the passivity and few volunteered as campaign workers for candidates as neighborhood associations remained inactive. ${ }^{48}$ These conditions were more perplexing for Kansai residents reported dissatisfaction prior to the election but, instead of stimulating election interest, the campaign rallies' "failure to deal with fundamental problems" channeled the discontent into boredom. ${ }^{49}$

In rural Japan the situation was, if possible, even worse. Reports from the northernmost island of Hokkaido admitted the failure to develop an election awareness in the hinterlands. Concurrently, northeastern Japan's voters took little interest in the election or enthusiasm about the campaign. ${ }^{50}$ Aomori candidates counted themselves fortunate to attract a crowd of 50 persons since many rallies there opened without any audience at all! $!^{51}$ The story repeated itself in central Japan where officials blamed the election's stagnation on "old order 
candidates" running in the campaign. Apparently, such types were still good to kick around. A Yomiuri correspondent got some revenge on the police censor when he censured campaign rally speeches for ignoring such immediate problems as Japanese-Soviet relations, government assistance to small scale industries, and the food shortage. ${ }^{52}$ Instruction 14, of course, forbid discussion of such topics. Dull campaigns typified Mie, Shiga and Wakayama Prefectures and the press blamed a "hangover" from the party politics' era for Iwate's apathy. ${ }^{53}$

The only two genuine election hotbeds were Nagano, where the local Adults Association worked feverishly in the campaign, and southernmost Kyushu's Kagoshima Prefecture. One reporter praised the latter as "so passionate about the election that it shamed its neighboring prefectures," but a less impassioned, and less charitable one, traced this zeal to Kagoshima's abysmal level of political underdevelopment that precluded any deviation from the official government line. ${ }^{54}$

Even the April 18 American air raid conducted by 16 B-25 bombers at roof top level over Tokyo, Yokohama, Nagoya, Kyoto, and Kobe did not interject any animation into the lackluster campaign. Air defense authorities considered an air attack against the home islands inevitable, but the surprise attack came as a shock. It was the first taste of war for the homefront and, indeed, until then little had changed dramatically in Japan since the opening of the Pacific War. ${ }^{55}$

In the raiders' wake, Tokyo police reported a run on food stocks, particularly non-staple items and some hoarding. Business at tea shops and meeting places dropped by $70 \%$ the day of the raid. ${ }^{56}$ Perhaps the only patrons were undercover police observing each other. The raid similarly restricted election campaigning.

The Home Ministry, in accordance with its previously announced instructions about air attacks during the election, suspended campaign rallies. The ban lasted four days, punctuated in Tokyo by false air raid alerts sounded by nervous air defense officers. Nationally the ministry imposed similar restrictions. Ozaki Yukio, for example, in a letter from Mie confided that there was great confusion there as a result of rally cancellations; Nakano Seigō's Kochi City appearance was cancelled; and Noyori Hideuchi (1885-1968), standing in Kyushu's Oita Prefecture, also reported that campaign rallies there had been suspended. ${ }^{57}$ The Political Council instructed its candidates to 
substitute a pamphlet campaign when air raid alerts suspended their campaign rallies. ${ }^{58}$

A foreign journalist in Tokyo believed that the Tojo government used the raid as a pretext to reinforce discipline, an interpretation supported by newspaper editorials that stressed the edifying effects of being bombed. ${ }^{59}$ Strict censorship accounted for some self-fulfilling analysis but not all Japanese shared the notion that bombing was good for you. Reform rightists furiously lambasted the government and the military for their failure to live up to previous "boasting" about the air defense system's invincibility. They also accused the government of negligence because its "total absorption" in the election campaign had given enemy bombers the chance to strike Japan. ${ }^{60}$ As an accurate political barometer, the Political Council took away any silver lining when it warned its candidates against taking advantage of blackout regulations to conceal illegal house to house campaign visits, vote buying, or bribery. ${ }^{61}$ The new politics seemed remarkably like the old.

The Doolittle Raid temporarily interrupted electioneering, but despite some sentiment to the contrary, the Home Ministry never wavered in its determination to see the election through to its conclusion. ${ }^{62}$ As a campaign rally topic, denouncing the airmen's barbarism for bombing a primary school was sure to draw applause. Beyond that, it had no great affect on the election.

Unable to conceal such widespread apathy, the government encouraged explanations that blamed everything and everyone but itself. The candidates' lack of style, an increased workload for farmers during their planting season, and a lingering turn off effect from political party campaigns became culprits. ${ }^{63}$ Others excused the election campaign's dullness because it was unfair to compare the 1942 election to the "mob psychology" that dominated political party campaigns. ${ }^{64}$ Apparently wartime elections should be dull. No one questioned why candidates suddenly lacked style either.

Attendance at Tokyo election campaign rallies provides a quantitative comparison to the two previous general elections. It is true that in 1942 the Metropolitan Police Board requested candidates in Tokyo's seven constituencies to limit themselves to three campaign rallies per day, not exceeding 100 per candidate for the entire campaign; to suspend nighttime rallies in case of air raid alerts; to suspend rallies if 
an air raid warning occurred; and to limit automobile use to one per day per candidate. ${ }^{65}$ Such restrictions were not covert police attempts to stifle campaigning. A scarcity of resources plus a record number of candidates in Tokyo necessitated them. Gasoline and paper rationing, for instance, restricted candidates' mobility and publicity. Even three rallies per candidate per day meant potentially 300 daily, taxing the voter, already election weary from the prolonged enlightenment campaign, to the limit.

In the 1936 general election, Tokyo's seven districts yielded 87 candidates who held 5,304 campaign rallies, approximately 61 rallies per candidate averaging about 128 listeners per rally. ${ }^{66}$ Incomplete police data for the 1937 general election reveals even higher attendance, averaging about $130-140$ persons per rally although few candidates (68) held less rallies (3,200 plus) ${ }^{67}$ In 1942 more candidates (97) held more rallies $(4,358)$, but attendance dropped quantitatively to around 322,000 total, an average of 74 per rally. ${ }^{68}$ Accompanying this sharp decrease in campaign rally crowds was a sharp increase in the number of cautions and of suspensions the police ordered at the rallies. This strict police enforcement of Instruction 14 undoubtedly was conducive to stereotyped candidate speeches that bored voters because of the speeches' vagueness and lack of relevance to contemporary problems and issues. It is tempting to equate police restrictions as the cause of poor rally attendance, but the examination of a specific candidate's campaign quickly shows the pitfalls of such an approach.

Recommended incumbent Pak Ch'un-kum (1891-1973), in 1932 the first Korean ever elected to the Imperial Diet, based his jiban in Tokyo's Fourth District. Having about 1200 Korean voters, it was the largest single Korean voting bloc in Japan. In his 1937 campaign, Pak enjoyed the largest average rally audiences, over 780 per speech, but in 1942 this figure dipped to around 170 per speech. Police reported that an unrecommended Korean candidate split Pak's jiban and drew away Pak's potential supporters. This formidable opponent, capitalizing on his own previous election experience as a municipal office candidate and on the assistance of community leaders, boldly invaded Pak's jiban and ran an active speech campaign opposing Pak's election platform. The candidate allegedly supplemented his campaign through vote buying and police had his campaign workers under investigation 
for such offenses. Pressed by a determined opponent in a tough race, Pak seemed unable to generate his previous voter appeal and police judged his re-election chances as slim. ${ }^{69}$ Traditional election practices, trying to capture an opponents' jiban, utilizing community leaders, and even buying votes, seemed to play as important a role in the decrease of Pak's campaign audiences as did police restrictions on his campaign rhetoric.

The Tojo cabinet and the Home Ministry did endeavor to spark voter interest in the campaign. Tojo dispatched his cabinet ministers nationwide between April 18 and 29 to speak in support of recommended candidates and the yokusan election as part of the Political Council's overall coordinated campaign finale against their opponents. The government also employed radio broadcasts more extensively than in previous election campaigns to try to reach voters via the neighborhood association meetings. General Abe's own neighborhood association meeting appeared in the Asahi newspaper but perhaps the photo of a cherubic Abe flanked by three thoroughly uncomfortable looking neighbors who seem anxious for their cue to leave lacked the desired effect.

On April 4, Vice Home Minister Yamazaki Iwao (1894-1968) used a 15-minute radio address to explain election goals and the proper way to evaluate rival candidates. ${ }^{70}$ Home Ministry officials also contributed to Shüho with articles like that appearing in the March 25 issue explaining that the election campaign was the domestic counterpart of the overseas military campaign. ${ }^{71}$

On April 27, the Tojo government sponsored its largest campaign rally at Hibiya Park. Prime Minister Tojo's speech, broadcast nationally, reviewed the military triumphs to date. He then exhorted the electorate to go to the polls for their single vote was the equivalent of one building block in the construction of Greater East Asia. General Abe followed and told his audience that, although easier said than done, they must work together to eliminate the electoral abuses that exemplified past election campaigns. ${ }^{72}$ Tojo attached utmost importance to the widest possible dissemination of these speeches and the Metropolitan Police Board ordered its police to collect written reactions to the Hibiya radio broadcast from neighborhood association leaders, school principals, factory managers, and small merchants, in short, the 
Cabinet Ministers' Speeches

for the Election in 10 Major Cities

\begin{tabular}{|c|c|c|c|}
\hline City & Date & & Speakers \\
\hline Nagoya & $4-18-42$ & 1 P.M. & $\begin{array}{l}\text { Justice Minister Iwamura, Election Puri- } \\
\text { fication Central League Director Tazawa, } \\
\text { IRAA Central Cooperative Committee Di- } \\
\text { rector Gotō Fumio }\end{array}$ \\
\hline Kobe & $4-18-42$ & 7 P.M. & $\begin{array}{l}\text { Home Minister Yuzawa, Cabinet Informa- } \\
\text { tion Bureau Director Tani Masayuki (1889- } \\
\text { 1962), Andō Kisaburō }\end{array}$ \\
\hline Osaka & $4-19-42$ & 2 P.M. & Yuzawa, Tani \\
\hline Kyoto & $4-21-42$ & 7 P.M. & $\begin{array}{l}\text { Nakai Yotarō (1887-1953) Retired Lieuten- } \\
\text { ant General, Tazawa, Finance Minister } \\
\text { Kaya Okonori (1889- ) }\end{array}$ \\
\hline Kanagawa & $4-22-42$ & 6 P.M. & $\begin{array}{l}\text { Assistant Information Bureau Director } \\
\text { Okumura Kiwao (1900-1969), Yamazaki } \\
\text { Iwao, Maruyama Tsurukichi (1883-1956) }\end{array}$ \\
\hline Sendai & $4-23-42$ & 7 P.M. & $\begin{array}{l}\text { Education Minister Hashida Kunihiko } \\
(1882-1945), \text { Tazawa, Andō }\end{array}$ \\
\hline Matsuyama & $4-26-42$ & 7 P.M. & $\begin{array}{l}\text { Vice Justice Minister Ōmori Kota (1887- } \\
\text { ?) }\end{array}$ \\
\hline Yokohama & $4-29-42$ & 2 P.M. & Yuzawa, Kaya \\
\hline Fukuoka & $4-29-42$ & 9 A.M. & Omori, Gotō Fumio \\
\hline Sapporo & $4-29-42$ & 1 P.M. & Iwamura, Maruyama \\
\hline
\end{tabular}

* Source: YS, March 14, 1942, 2.

middle class. They received generally laudatory replies, but several respondents simply wrote that they had not listened to the broadcast or that they had no opinion about it. ${ }^{73}$

It seemed as though the Tojo government was trying to convince itself that the election campaign was a success. In fact, despite the considerable time, effort, and resources that the government devoted to the campaign, the public did not participate properly in the enlightenment or in the election campaigns. Both campaigns failed to attain their anticipated goals of demonstrating homefront unity. 


\section{Chapter VI \\ Candidates and Campaigning}

The 1942 election was the hinge on which Japanese political leadership for the next decade turned, but the stigma attached to election campaigning in 1942 continues to make that campaign a sensitive political topic in Japan. The Occupation authorities' subsequent "purge" of all recommended candidates is generally regarded by those Japanese historians who prefer to dismiss conveniently the 1940's as "fascist" or as "militarist" as "proof" of the validity of their labels. Politicians who re-entered political life after the Occupation ended in 1952 naturally remain reticent about describing their 1942 campaigns. A visceral feeling persists that anyone, even independent candidates, who won election must somehow have supported the so-called "Tojo dictatorship."

I selected ten candidates whose campaigns illustrate electioneering techniques and interference problems in the 1942 general election. The availability and the reliability of source materials plus the requirement that the candidate's campaign exemplify his party, faction, or peer group's experience determined selection. Rōyama Masamichi (1895- ), Shioden Nobutaka, and Tsukui Tatsuo represent recommended "new men," Ozaki Yukio the Dōkōkai, and Nakano Seigō the Töhōkai. Miki Takeo (1907- ), who in 1975 became Prime Minister of Japan, typifies independent incumbents and Nishioka Takejirō's (1890-1958) extreme case shows government interference against Diet splinter group members' campaigns. Noyori Hideuchi's campaign points out the pitfalls an independent, former parliamentarian might encounter while attempting a political comeback. Miyake Shoichi (1900- ) exemplifies former Socialist Masses Party members' campaigns. Finally, Shimomura Jirō's (1890-?) situation vividly demonstrates naked interference completely disrupting a campaign.

\section{Theory to Practice}

Professor Rōyama Masamichi was one of pre-war Japan's preeminent political scientists. In 1939, he resigned his Tokyo Imperial 
University professorship to express his dissatisfaction with the university president's handling of the so-called Kawai Eijirō Affair. ${ }^{2}$ A former member of the defunct Shōwa kenkyūkai, Rōyama's trenchant political commentaries appeared regularly in the leading Japanese opinion journals.

In any Japanese election, the so-called "cultured man" (bunkajin) commands respect, and the 1942 election "especially prized" such persons as "new men." ${ }^{3}$ Friends had already sounded out the former professor about running for office and then Gunma Prefecture Governor $\mathrm{Mu}$ rata Gōrō asked Rōyama to stand for election in that prefecture. Although unenthusiastic about becoming a Political Council recommended candidate (Rōyama thought his personal connections in Gunma would suffice to elect him even lacking a recommendation), he could not politely refuse Murata's request. He still believes that Murata personally, and not the local Political Council branch, selected him because the governor wanted to capitalize on Royama's well known name. ${ }^{4}$ For his part, an election campaign offered Rōyama the unique opportunity as a candidate to apply the political science theories that he had been studying and writing about for the past two decades. ${ }^{5}$

Although Rōyama resided in Tokyo, no restrictions existed to prevent his standing for election in his native Gunma Prefecture. Actually, this practice of returning to one's home or a different prefecture to stand for election was widespread in the Japanese electoral world. Finance Minister Kishi ran in his native Yamaguchi Prefecture and the Tojo cabinet's Agriculture and Forestry Minister Ino Hiroya, though a Tokyo native, stood in Mie Prefecture. Gunma's Second District, where Rōyama campaigned, was a defunct political party stronghold so political analysts expected "new men" to encounter great difficulties being elected. ${ }^{6}$ Three of the district's four recommended candidates were incumbents, leaving Royama the sole political newcomer. Kogure Sanjirō (1868-1959), a seven term Dōkōkai member, was the only independent incumbent but four other candidates made a total of nine contestants for the four allotted Diet seats.

Press reports from the Gunma campaign generally lauded Royama. The Kokumin, for example, singled him out as the sole exception to an otherwise dull campaign. Conversely, the Nichi Nichi reported all recommended candidates enjoying favorable popular response and 
Rōyama particularly possessing both "new man" appeal and local Adults Association support. The Miyako's correspondent, however, thought that the Gunma situation represented the triumph of what he termed the "old faces" and not the patriotic spirit that supposedly would characterize the election. Nevertheless, political analysts predicted that Royama faced a stiff battle because Kogure held a strong jiban, and, as late as April 26, the Höchi believed Royama's election in doubt. ${ }^{7}$

In fact, Royama finished an unexpectedly high second in the voting. He attributed his success to hard work, personal enthusiasm, and campaign funding from friends as well as from his own pocket. ${ }^{8}$ By prior agreement, each candidate limited himself to 100 campaign rallies so Rōyama began his rallies at 10 a.m. every morning and continued until five each afternoon. No matter how small the audience, he spoke impassionately about the election's importance, the recommendation system, the postwar future of Japan, the farming villages' problems, and continental, i.e., Sino-Japanese affairs. ${ }^{9}$ Despite his recommendation, he campaigned vigorously as one of the few recommended candidates who displayed more zeal than his independent rivals.

Such tactics originated in Rōyama's previous theories that successful campaigning depended on making an impression and on stirring the electorate's emotions. Word of his infectious mood and zealousness spread and more and more listeners began to attend his rallies. Assistant speakers from Tokyo also aided his campaign, as did his many friends and relatives in Gunma.

Rōyama also benefited, albeit without his knowledge or solicitation on his part, from pressure that Governor Murata exerted on Gunma's community leaders to elect only recommended candidates. Murata interfered on his own initiative, without specific Home Ministry instructions. He tried to avoid interfering too openly because early detection of his meddling would have created problems for the election campaign. ${ }^{10}$ Indeed, after the election, defeated incumbent Kogure did allege that Murata had directed community leaders to vote for specific candidates and to assist in their elections. Police reportedly canvassed among the district's important families for votes for recommended candidates. ${ }^{11}$ Murata had such confidence in his tactics 
that he permitted campaign rallies to progress unhindered by the police since the recommended candidates, with his help, would win anyway.

Gunma's Second District provides a classic illustration of the manner in which a prefectural governor could use his influence to favor candidates identified as pro-government. It is true that Royama never requested such "assistance," but Murata, to insure that only recommended candidates won, saw it as almost a personal obligation to have the man he asked to become a candidate elected. Royama, however, outpolled three strong incumbents. His vigorous campaign certainly must be given credit for his election. Whether his dynamic campaign or official prefectural interference was more "responsible" for his election is a moot point, but, on the basis of his second place finish, perhaps interference was more instrumental in the third and fourth place finishers' election.

\section{The Anti-Semitic Drawing Card}

The fiercest campaign, in terms of candidate numbers relative to available seat numbers, occurred in Tokyo's sprawling Fifth District where 23 candidates (five recommended) vied for five seats. Covering 10 of Tokyo's 35 wards, the Fifth Constituency encompassed the western and the southern city areas and contained over 452,000 voters. A high percentage of intellectuals residing there and a large "floating vote" (uncommitted to a particular candidate) characterized the district's political complexion. The latter encouraged new candidacies as did the lack of strong incumbent opposition for only one incumbent, Makino Ryōzō (1885-1961), stood for re-election. ${ }^{12}$ The district became a magnet attracting "new men," 17 of the 23 candidates being political newcomers.

The excessive candidate numbers caused "complete disorder" in the district's election campaigns because the candidates lacked easily identifiable "distinctive traits."13 Retired Lieutenant General Shioden Nobutaka was the most conspicuous candidate, a distinction attributed to his anti-Semitism. ${ }^{14}$ Such a unique and incongruous topic gave Shioden an immediate attention getter in a lackluster campaign. It provided him with the chance to make a name for himself among 
voters despite the strict regulations governing campaign rally topics that restrained other candidates.

By way of illustration, on April 17, 203 rallies opened in Tokyo drawing about 15,000 listeners, about 70 each. That day police issued 50 cautions and suspended six campaign rallies when campaign orators touched topics that the police believed might lower economic production, be critical of a controlled economy, or create doubts among the public. ${ }^{15}$ A topical breakdown of such incidents for the entire campaign also reveals that police supervising campaign rallies adhered strictly to Instruction 14's directives governing the control and the guidance of campaign rallies. ${ }^{16}$

\begin{tabular}{|c|c|c|}
\hline \multirow{4}{*}{$\begin{array}{l}\text { Speeches abusing the IRAA or Political Council .... } \\
\text { Speeches slandering a controlled economy .............. } \\
\text { Speeches attacking government policies, bureaucrats, } \\
\text { and dividing the public \& military }\end{array}$} & \multicolumn{2}{|c|}{ Cautions/Suspensions } \\
\hline & 172 & 26 \\
\hline & 163 & 18 \\
\hline & 120 & 25 \\
\hline $\begin{array}{l}\text { Speeches "radically disrespectful and dangerous" .. } \\
\text { Speeches abusing the recommendation system }\end{array}$ & 74 & 15 (1 arrest) \\
\hline or recommended candidates & 73 & 6 \\
\hline Speeches attacking the nation's upper classes ..... & 55 & 7 \\
\hline Speeches creating public disunity or discord .... & 45 & 6 \\
\hline $\begin{array}{l}\text { Speeches using "improper language" \& causing } \\
\text { anxiety or confusion }\end{array}$ & 33 & ( 1 arrest) \\
\hline & & (1 arrest) \\
\hline & 819 & $128(3)$ \\
\hline
\end{tabular}

Such strict interpretation of Instruction 14's provisions could tend to make campaign rhetoric rather uniform and could reduce popular interest in Tokyo's election campaign. In such circumstances, a candidate possessing a unique platform and, as in Shioden's case, one that was not too sensitive as a campaign rally topic, had a very valuable asset. As Shioden himself crudely put it, "Differing from the other candidates, I talked about the annihilation of the Jewish influence lurking behind the war." 17

Initially reluctant to enter the election race, Shioden decided to run after supporters assured him that money was no problem and that he could freely state his own opinions. He received 20,000 yen $(\$ 10,000)$ from "Abe's Political Council" and insisted this donation came from zaibatsu funds, not from any secret army war chest. ${ }^{18}$ Funded and recommended, Shioden set out on the Tokyo streets to deliver the 
catechism of hate that he had discovered in Russia during service in the Siberian Expedition (1918-1922) and that he had nurtured ever since as an anti-Semitic agitator and hack pamphleteer. ${ }^{19}$

If Shioden only managed to be elected, his campaign might be dismissed as an example of bigotry playing on wartime phobias to amass votes, but Shioden received a totally unexpected, record shattering 76,250 votes, the most of any candidate in any Japanese election! Likening his election campaign to a parachutist dropped in the midst of enemy pillboxes, Shioden attributed his astounding triumph to his loyally serving the emperor, holding more than 80 campaign rallies, being recommended, and having a military background that, he felt, united the public and military sectors within his campaign. ${ }^{20}$

Post election analysis accounted for his success not in terms of his campaign rallies where turnout was not huge nor to his mediocre campaign literature, but rather to three factors: his military background, his status as an aviation pioneer, and his anti-Semitism that "was becoming the trend of the times." 21 More prosaically, Tokyo police contended that Shioden enjoyed the support of local Reservist Association chapters, the Mizuho kurabu, traditional rightists bellwethers like Baron Hiranuma and Tōyama Mitsuru (1855-1944), as well as the "intellectual class" and that his "fierce campaign" had aroused the public making Shioden a household name. ${ }^{22}$

Anti-Semitism probably was the key factor in Shioden's record breaking accumulation of votes. He premised his campaign on virulent anti-Semitism that tapped the Japanese public's racism and xenophobia. His theme of an "international secret organization" led by a "Jewish Directorate" (yudaya kanbu) that was responsible for World War One and the Russian, German, and Austrian Revolutions which, in turn gave Jews power in the so-called "anarchist camp" could appeal to anti-communists as well as middle class bourgeois "intellectuals." Simultaneously, his assertion that Jews "maintained interests in the American and British capitalist system and thus encircled Japan" struck responsive cords among the general public who could identify his rantings with enemy nations. ${ }^{23}$ Shioden's "ideal" candidate was one who would "smash the Jewish financial power manipulating America and England," and fertile ground existed in wartime Japan for the cultivation of anti-Semitism. ${ }^{24}$ 
The popular monthly Bungei shunjū characterized the Diet as "splattered with international Jewry's evil influence," and proposed that the standards of the notorious French anti-Semite Charles Maurras (1868-1952) be a litmus test for all candidates. ${ }^{25}$ As a Tokyo Imperial University student, the historian Irokawa Daikichi (1925- ) had to study the "Jewish Problem" and students as well as faculty seriously advanced anti-Semitism as a solution for the secret, Jewish, "Freemasonry" that threatened Japan and Japanese kokutai ${ }^{26}$ In such a receptive atmosphere, ambient bigotry thrived, and, combined with the wartime xenophobia, released Japanese racist impulses. The appeal was, at root, anti-foreign, symbolized by a sinister "Jewish directorate," and continual emphasis on Japanese uniqueness and national character easily led to such xenophobic racism. The topic was permissible for campaign rallies for it avoided Instruction 14's prohibition against employing racial war themes in campaigning. Shioden however managed to present the electorate with a non-Japanese, ostensibly easily identifiable "nationality" to hate during wartime. It was secret, international, and threatening enough to titillate voters without disrupting national unity. Anti-Semitism was the "ideal" campaign topic because it simply had no connection with wartime Japanese reality.

\section{Recommended Defeat}

The reform rightist political commentator and journalist Tsukui Tatsuo also campaigned in Tokyo's vast Fifth District. Perhaps due to his literary talents, Tsukui preferred the pen to the sword, and, eschewing the violence usually associated with reform rightists, had twice, unsuccessfully, stood for the Imperial Diet from his "jiban" in Kanagawa's First Constituency, Yokohama City. ${ }^{27}$ In 1942, Tsukui was the chairman of the Daitōa doshikai (Greater East Asia Comrades Society) which he and Fuke Toshiichi (1912- ) organized in 1942 to promote the candidacies of lesser known reform rightists in the general election. ${ }^{28}$

Tsukui himself had worked in conjunction with government planners to advance Comrades Society members' chances as possible candidates. However, typical of national reform rightist experience, the Political Council ultimately rejected all of his 30 suggested candidates. The Tokyo Political Council Branch, nevertheless, did recommend 
Tsukui and Fuke and the national headquarters in turn approved their selections. Tsukui claims that he was a disinterested party in this selection process and, to his knowledge, the police did not investigate him as a "suitable candidate" prior to his recommendation. Although recommended, Tsukui's campaign demonstrates the problems a recommended candidate might encounter.

A Political Council grant of 5,000 yen $(\$ 2,500)$ covered his election campaign expenses. ${ }^{29}$ Armed with a recommendation, campaign funds (kaban), and a small but active reform rightist organization supporting him, Tsukui's election chances seemed good. In retrospect, he believed that the recommendation hurt him more than it helped him for his campaign "lacked appeal and determination." A recommendation bred overconfidence. ${ }^{30}$ The recommendation also hurt him, Tsukui felt, among the local intellectuals who could exhibit an anti-government posture by voting for independents. Yet, as a man of letters, Tsukui had expected to make a successful appeal to this significant voting bloc. ${ }^{31}$

Tsukui concentrated his efforts on the campaign rally, opening three or four daily and focusing on two themes. First, he contended that the China War showed the need to reorganize the political world and that Diet reform would accomplish such renovation. Second, Tsukui stressed the need to develop a sound public opinion as the ideological and cultural basis for politics. He attracted respectable audiences, ranging from 20 to 150 persons. The local Adults Association chapter and a prominent prefectural assemblyman also lent their assistance. Despite such local help, Tsukui had several difficulties.

His election campaign bogged down. Neighborhood police described Tsukui's speech and pamphlet campaigns as praiseworthy, but lacking impact because voters could not identify him as a reformconscious candidate. ${ }^{32}$ Another difficulty was police activity. Local police maintained an around-the-clock surveillance on his campaign headquarters and stopped and searched his supporters, despite his recommended candidate status. Police also summoned visitors to Tsukui's home to the local police box for interrogation. The severe attitude, Tsukui maintains, resulted from the local police chief's longstanding ties with former political party politicians and, consequently, as an "outsider," Tsukui received harsh treatment from the police. 
Following orders to prevent election violations, local police were also after a notorious district "election broker" and closely checked all candidates' activities in hopes of catching the culprit bartering votes. ${ }^{33}$ Indeed, as the following chart shows, Tokyo police seem to have enforced election regulations impartially against recommended and non-recommended candidates alike.

Election Law Violations (Tokyo Prefecture)

\begin{tabular}{|c|c|c|c|c|}
\hline Type & Recommended & Tōhōkai & Other & Independent \\
\hline Vote Buying & $\ldots \quad 52$ & $\ldots$. & 21 & 303 \\
\hline Door-to-Door Solicitations & s $\ldots . \quad 35$ & 9 & 5 & 116 \\
\hline Illegal Campaign ................... & ....... 34 & 9 & 12 & 120 \\
\hline Obstruction & 1 & .... & 1 & 2 \\
\hline Unsuitable Vote & $\ldots \ldots$. & $\ldots$. & 1 & $\ldots$. \\
\hline Worker Violation .................. & $\ldots \ldots .$. & $\ldots$. & $\ldots$. & 4 \\
\hline Other & 6 & 4 & 5 & 21 \\
\hline & 130 & 22 & 44 & 578 \\
\hline
\end{tabular}

Source: Keishichō, "Shūgiin senkyo hanzai shirabe," May 30, 1942 in Archive Title 1464 Reel 212, Frame 80455.

Whether or not the disruption of Tsukui's campaign was intentional or incidental to strict election enforcement cannot accurately be determined. It does highlight the tenuous line between legal police activity and election interference.

A greater obstacle than the police was Tsukui's lack of a kanban (reputation as an influential politician or political appeal). Tsukui "shared" his political ideology with three other reform rightists who, by appealing to the same voting bloc, effectively split the reform rightist vote among four competitors. Tsukui finished a lowly ninth with 18,000 votes. Advertising himself as Japan's human bullet, another reform rightist Kodama Yoshio (1911- ), whose later "Lockheed Connection" would help to topple a government, attracted a similar voter type and finished eighth with 19,000 votes. If combined, the 37,000 votes represented a third place finish and election. ${ }^{34}$ Moreover, a traditional rightist, Shioden, with a "unique" kanban attracted votes in record numbers that might otherwise have gone to Tsukui.

The lack of the Japanese electoral world's traditional "three ban" (jiban, kaban, kanban) spelled Tsukui's defeat. Yokohama was his jiban; the Political Council supplied his kaban, but it also had to 
support its other recommended candidates; other candidates shared his kanban. Recommendation alone did not guarantee victory. Traditional election criteria remained necessary.

\section{The Legend as Campaigner}

Aspects of Ozaki Yukio's anti-government, anti-Tojo, and antiPolitical Council campaign have already been mentioned. The Meiji Constitution by providing a legal framework adhered to by the Tojo government and Ozaki's unique stature in the political world made possible his stinging rebukes to "national unity" in terms unknown in "totalitarian" or "militarist" regimes. Ozaki was the only representative who had been elected in every election in Japanese constitutional history from 1890 to 1942, and, with good reason, was the so-called "god of constitutional politics." He was also a shrewd campaigner who drew on years of campaign experience to capture campaign audiences. At 84 , Ozaki even turned his deafness to advantage by forcing the police supervising his rallies to hold up signs with "Caution" or "Suspension" written in large characters should the occasion arise. His appeals to liberalism made the occasion frequent.

An Ozaki election rally always promised to be a memorable event. Absolutely secure in his Mie Third Electoral District jiban, Ozaki placed his talents and appeal into service for his beleaguered Dōkōkai colleagues. Stumping for Tagawa Daikichirō's campaign, Ozaki helped to develop a "rousing campaign" through ringing oratory praising liberalism and touching sympathetic chords among listeners. Even as the police escorted Ozaki from the rostrum after the so-called "Third Generation" speech, the crowd shouted "Police suppression" and cheered the charismatic old politician. ${ }^{36}$

Following the alleged lèse majesté incident, prosecutors questioned Ozaki on April 23 and confined him overnight at Sugamo Detention Center where guards gave the old man extra blankets to ward off the night chill. Freed the following morning, the police later that day re-arrested Ozaki and charged him formally with lèse majesté. ${ }^{37}$ Released prior to his court appearance, Ozaki returned to Mie and campaigned successfully for re-election.

Newspapers buried Ozaki's arrest and his indictment in their back pages identifying him cryptically as "One Mie Candidate" arrested 
by the police. Finally, on April 25, the Asahi acknowledged that indeed Ozaki had been arrested but, because of his distinguished past service, he would be released after the official indictment. ${ }^{38}$ The arrest did make news at the court where the emperor advised Justice Minister Iwamura to keep him informed of all developments in the Ozaki case. $^{39}$ Political opponents hurled the lèse majesté canard at Ozaki during his Mie campaign in a desperate effort to unseat the old warrior. As a contemporary observed, however, while Ozaki's remarks were imprudent, there could be no doubt about his loyalty. ${ }^{40}$

On July 4, the prosecution decided to try Ozaki and, on December 21, 1942, he was found guilty of lèse majesté and sentenced to eight months confinement; a verdict commuted to two years probation because of his advanced age. That did not end the affair. Ozaki appealed the verdict and, on June 27, 1944, the Appeals Court overturned the lower court ruling by declaring Ozaki innocent of all charges. ${ }^{41}$ Ozaki's ultimate vindication overshadowed his Dōkōkai colleague Tagawa's election defeat which, one of Tagawa's opponents maintains, directly resulted from the adverse popular reaction to Ozaki's remarks. $^{42}$

\section{The One Man Campaign}

Nakano Seigō possessed advantages similar to Ozaki's, an invincible jiban in Fukuoka's First District, oratorical gifts, and the additional benefit of a large, national organization behind him. Since the Political Council would recommend no Tōhōkai candidates, the Tōhōkai directorate instructed its 300 nationwide branches to prepare for the election campaign being careful not to create suspicions of election impropriety in their planning. Since the party was organizing an "active campaign" to gain political power, "idle or inactive" branch directors would be replaced. ${ }^{43}$

Nakano himself was the center of a whirlwind national speaking tour that carried him from the northeastern provinces on April 6 through southern Kyushu by April 22. He spent only two days campaigning in his own district, depending instead on his jiban organization for his election. ${ }^{44}$ His ardor, characterized by an unyielding antigovernment stand, made Tōhōkai members uneasy. After all, it was wartime and the rank and file did perceive homefront unity as a 
desirable goal. Thus, Honryō Shinjirō (1903-1971) repeatedly advised Nakano to soften his hard line; Yamaguchi branch members openly questioned Nakano's attitude; and Tōhōkai General Affairs Director and Diet incumbent Ōishi Dai (1903- ), running for re-election in Kochi Prefecture, counseled Nakano against such anti-government campaign tactics. $^{45}$

During his national campaign tour, Nakano struck at the Political Council, at the economic system (less "Jewish-like liberal capitalism") and at the incompetent bureaucracy. He regularly questioned government policies and specifically demanded that the government exclude zaibatsu influence from the so-called Southern Regions. ${ }^{46}$ With a certain dry wit, the Police Bureau observed that Töhōkai rallies tended to require police cautions and that in Tokyo the party ranked first in what police jargon termed "deviation" from Instruction 14's official control and guidance standards. ${ }^{47}$

Internal bickering and overambitious planning stretched Tōhōkai resources too thin and only seven of its 47 candidates, Nakano included, won election. Nakano personally blamed the humiliating defeat on illegal government interference and intimated that prefectural governors and regimental area commanders conspired to rig the election. ${ }^{48}$ Individual Tóhōkai candidates' experiences testified to the close attention that the police gave to their campaigns.

In Kagoshima's First District, Oda Shigeru (1892-?) claimed that the local governor instructed public employees, police chiefs, school principals, Keibödan and Adults Association members to cooperate to elect recommended candidates while simultaneously, he equated independents with traitors. The Adults Association, as an organization, endorsed specific recommended candidates and neighborhood council meetings turned into political election discussions. Marked ballots designated recommended candidates for voters. In Oita Prefecture, the Tóhōkai candidate alleged that the police director solicited support for recommended candidates from among the community leaders and advised them not to help independents' campaigns. There was also alleged campaign worker intimidation. In Niigata, Tōhōkai candidates encountered strict police supervision that may account for the defeated Tóhōkai candidate's decision to quit politics, a move that left a serious gap in the party's regional organization. ${ }^{49}$ Tōhōkai 
backed candidates alleged similar instances of prefectural government interference in their campaigns in Kochi, in Gunma, and in Nagano Prefectures. ${ }^{50}$ Additionally, police censors at least twice deleted articles in the party's official journal, Tódairiku (Eastern Continent), for suggesting that the Political Council was plotting to revive a "bakufu" order and for spreading Nakano's anti-government philosophy. Also censored were two Tōhōkai auxiliary periodicals for carrying Nakano's opinions and for the disrespect and possible lèse majesté that the government discovered in the party's plan for post-election Japan. ${ }^{51}$

In dealing with other reform rightists, the Tojo government and the police were impartially severe. Akao Bin's Kenkokukai ranked second to the Töhōkai in "deviation" from official government standards. Authorities regarded the Ködo renmei as "clearly anti-Political Council," and police scrutinized the Ikken kinnō undo for its slanderous campaign against the Political Council, the zaibatsu, and former political party members. Luckily, the Rikken yoseikai did receive close attention leading police to arrest three of its members for plotting to murder victorious candidates should Director Tanaka lose, as he did, his election bid. ${ }^{52}$

The Töhökai's election experience typified that of reform right organizations and candidates. Their anti-government, anti-Political Council platforms led to open disagreement with and criticism of the Tojo government. Regarding this attitude as dangerous, the police moved to silence these vociferous critics by intimidation, arrest, harassment, and strict control of their campaign rallies. Also revealed was the reform rightist followers' ambivalence expressed as splits between the membership and the leadership. These cleavages stemmed from the contradiction between the Tojo cabinet's requirements for homefront wartime unity and the reform rightist leaders' requirements for their respective organizational programs. This equivocal sentiment represented the reform right's traditionally unclear attitude toward parliamentary politics, while their past tendency to use violence to achieve their ends still frightened away potential supporters. Unable to live down their violent heritage and without jiban unable to cope with prefectural level police suppression, the reform rightists fared very poorly in the 1942 election. Not only did they fail to win 
in great numbers as they had expected, but also the "old" political leadership maintained its hold on the Diet.

\section{Unrecommended in the Countryside}

The 1942 election campaign in Tokushima's Second District was Miki Takeo's second national campaign. In 1937, he became the youngest man ever elected to the Lower House. Previously an independent, in 1941 Miki joined the Yokudo and his 1942 situation characterized that of first and second term Yokudo members. The Tokushima Political Council Branch bypassed him for recommendation in favor of Akita Kiyoshi and two "new men," both ironically older than Miki and both with the same surname, Miki Yokichirō (1901- ), a successful local businessman and Miki Kumaji (1880-?), a prefectural assemblyman. The national headquarters in turn approved these branch choices.

Miki Takeo believes that his extended study abroad at the University of Southern California made him unacceptable to the Tojo government, and thus to the Political Council. ${ }^{53}$ Since Tokushima was a rural area and a political backwater, Miki's American sojourn also hindered his election campaign. From the very outset, Miki, as an independent, had to deal with the accusation that he was pro-American and was conspiring to spread enemy propaganda. It "followed" that voting for him was treasonous because he would serve as an enemy spy within the Diet. ${ }^{54}$

Miki's campaign rallies naturally attracted the usual police surveillance but, since the police judged Miki as having a good chance of being re-elected, they concentrated their efforts to obstruct his campaign. One tactic that the police used against Miki paradoxically created the impression of a thriving campaign. Plain clothes officers who attended Miki's rallies in hopes of uncovering election violations inadvertently, by their very presence, swelled attendance at those rallies. Such deceptive crowd size in turn prompted the press to describe Miki as typical of the growing popularity of independents who were pressing recommended candidates. ${ }^{5 \tilde{5}}$

To try to minimize any voter popularity in Miki's case, following his rallies the police questioned individual listeners either trying to entrap them or to intimidate them. Police also solicited votes for rec- 
ommended candidates and told voters that Miki was indeed a traitor. The local Adults and Reservist Associations "combed the countryside" campaigning against him, and local support dried up because of police intimidation. For example, the local police chief advised a local contractor, who had assisted Miki financially in 1937, that all his municipal contracts would be withdrawn if he unwisely insisted on again backing Miki. When prefectural outsiders like Miki's former Waseda University professors journeyed to Tokushima to speak on his behalf, their support was more than counter-balanced by vigorous Adults Association opposition to him.

Although these obstacles convinced Miki that he would not be re-elected, he did win easily, finishing as he had in 1937 in third place and gaining an additional 800 votes in the process. The more shocking defeat in Tokushima was that of the unrecommended fourth termer, former Minseito member Manabe Katsu (1881-1963), the 1937 frontrunner. Voters apparently rejected 62 year old Miki Kumaji as too old in a "new man" election. Miki Takeo's victory, despite police and public association interference, may be traced to his youth, his determination, but, more plausibly, to his opponents' caliber and to his jiban. Although Miki's account provides scant information about that jiban, it must have been instrumental in his re-election. He surely cultivated local ties during his five year Diet term and built himself a solid jiban that was resilient enough to withstand prefectural interference and still bring him enough votes for victory. A strong jiban could be decisive. In Tokyo, for instance, police analysts quickly conceded Dōkōkai members Hatoyama Ichirō and Andō Masazumi's re-election for both their jiban remained virtually unchanged since $1937 . .^{56}$

Miki Takeo's experience shows that a strong jiban could offset the lack of a recommendation and localized interference. Prefectural authorities interference certainly hindered potential campaign workers' willingness to participate in the campaign, but it was not necessarily a decisive factor in the campaign. The traitor slur, interesting because pro-government candidates employed the exact same smear rhetoric in 1890, 1915, and 1928 elections, also failed, as it failed against Saitō Takao (1870-1949), Ozaki Yukio, and Hatoyama Ichirō, when the electorate returned all those men to the Diet. Independent, incumbent 
politicians remained difficult to unseat as 47 of 133 such candidates won re-election.

\section{Supervising Candidates}

The campaign of Nishioka Takejirō (1890-1957) exemplified prefectural government interference at its extreme. Representing Nagasaki's First District, the former Seiyükai member was in his sixth term and, in 1942, affiliated himself with the Köa giin kai. His constituency included Nagasaki City where, in August 1941, a municipal "recommended election" married by charges of prefectural and city government interference against independent candidates occurred. ${ }^{57}$

Police constantly harassed Nishioka's campaign as officers searched his campaign offices and confiscated his campaign materials; maintained continual surveillance on his campaign headquarters; tapped his telephone calls; followed visitors leaving his home; and intimidated voters by insinuating that they should only elect recommended candidates. $^{58}$ They coupled this "negative" interference with "positive" measures as the police openly canvassed for votes for recommended candidates and the Nagasaki governor used his own relatives and prefectural teachers to spread support for recommended candidates. In his capacity as IRAA prefectural branch director, the governor instructed community leaders that:

The existing, so-called independent candidate system of elections is unsuitable for today's requirements. The general public must be made to realize that fact fully. ${ }^{59}$

Furthermore, local ward office officials told neighborhood association members that if independents won election, the governor and the police director would be dismissed. On an even more personal level, a village police inspector appealed to community leaders not to support Nishioka or else he, the inspector, would be transferred. It was a powerful appeal, if the official in question were a popular one. Other independents like former Seiyūkai member Honda Eisaku (1886-1948) felt the wrath of official prefectural displeasure. An enthusiastic supporter who applauded a bit too loudly and too long for one of Honda's speeches, promptly found himself detained and interrogated by the police. At polling stations on election day, the police told voters for whom to vote and, to make sure voters followed such 
heavyhanded suggestions, one detective rigged a mirror that enabled him to watch voters marking their ballots. Not unexpectedly, no independent candidate won in Nagasaki's districts.

The IRAA and Adults Association also worked against independents. On April 1, for instance, both associations issued "candidate qualifications" that included promoting patriotic and sincere men for office and disparaging those who ignored the national good for their own interests, namely independent candidates. ${ }^{60}$ It was no April Fool when the governor announced on election eve:

We will appreciate your gracious cooperation. Tomorrow all of us together will go to vote properiy. To be sure, no one will watch you at the polling station, but "Heaven knows and earth knows." With a true feeling vote for a true person. Those who damage national polity are our enemies. With our one, mighty vote this kind of person will be punished..$^{61}$

Nishioka received his punishment even before election day. Police totally disrupted his re-election campaign because of a technical election law violation resulting from his campaign manager's oversight. Using the pretext that Nishioka's supporters began campaigning prior to the official election period, police officers arrested his campaign manager, his campaign workers, and ultimately, Nishioka himself when he stepped off the Tokyo train at Nagasaki Station. ${ }^{62}$ Although prosecutors released Nishioka after several days' detention, campaigning was impossible and he never recaptured lost ground. After his defeat, he filed indictments against the Nagasaki governor, the Nagasaki City mayor, and the local police director. Police investigators placidly claimed no basis for Nishioka's allegations existed.

The case shows how zealous police election law enforcement could totally disrupt any campaign and it also shows the difficulty of distinguishing between legal and illegal police election activities. As seen on the following chart, in 1942 both the number of alleged election law violations and the number of persons involved in such incidents decreased in all but one category (Other) when compared to the previous 1937 general election. The prefectural authorities, especially the governor, did create an anti-independent candidate atmosphere, but Nishioka's overzealous supporters did technically violate election laws, meaning grounds for arrest did exist. A similar case occurred in Chiba Prefecture where an independent alleged that 
Election Violations Nationally in 1942 and in 1937

1942

1937

Number/Persons
of Involved
Alleged
Violations

Vote Buying

Election Broker

Solicitation

Il'egal Campaign

Obstruction

Conflict of Interest

Public Employee

Irregular Vote

Active After Close of Campaign

Worker Violation

Pamphlet Violation

Finance Violation

Other

Total

$463 / 2,556$
$9 / 10$
$519 / 574$
$326 / 476$
$16 / 24$
$2 / 8$
$37 / 45$
$45 / 82$
$1 / 1$
$27 / 61$
$116 / 129$
$9 / 12$
$97 / 128$
$1,666 / 4,111$

Number/Persons

of Involved

Alleged

Violations

$908 / 5,228$

$56 / 92$

$851 / 1,100$

$732 / 972$

$124 / 139$

$4 / 7$

$111 / 134$

$87 / 118$

$3 / 3$

$168 / 232$

$283 / 353$

$70 / 108$

$68 / 94$

3,465/8,480

Source: Maruyama Sei, "Senkyo mēmo" (Election Memo), Shükan Asahi, (May 17, 1942), 12-13.

the police disrupted his rally and detained him for questioning: the police claimed that they suspended the rally only after the candidate refused to heed two previously issued cautions. ${ }^{63}$ There were cases where both regulators and regulated seemed to have grounds for complaint, further blurring the line dividing legal police work and police interference.

\section{Misplaced Faith}

Journalist, polemicist, militant right wing anti-communist, and in 1932 the founder of the pro-emperor newspaper Teito Nichi Nichi shimbun (Capital Daily News), Noyori Hideuchi attempted a political comeback in 1942. Noyori stood for the Diet in 1924, in 1928, and finally in 1932 won election as a Seiy ükai representative from Oita Prefecture's First District. After a single term (1932-1936), Noyori returned to his newspaper enterprise. He had practical campaign and legislative experience, and presumably still retained a skeleton Oita jiban plus a newspaper to promote his cause. Additionally, as a prominent supporter of the Axis Alliance, Noyori thought that his politics reflected the spirit of the times and that his time had also come. 
Noyori had several reasons for standing as an independent candidate. Tojo's February 18 speech calling for new men to create a fresh, powerful Diet encouraged Noyori for he believed that the government would not interfere in the election. The public would realize that he was not using the election as a stepping stone for personal advancement so that even as an independent he might win election. Finally, he felt an obligation to those who endorsed him. ${ }^{64}$ Influential and powerful men like traditional rightist Genyōsha kingpin Tōyama Mitsuru, the managing editor of the Japanism advocate Nihon oyobi Nihonjin (Japan and the Japanese), Miyake Yujirō (1860-1945), Shiratori Toshio and Nakajima Chikuhei, both recommended candidates, all endorsed Noyori. One campaign poster included testimonials by no less than five retired generals and admirals who billed Noyori as the champion "to annihilate Britain and America." Exactly how Noyori would do this was left to the voter's imagination.

During his election campaign, Noyori relied on letters of endorsement from the above backers as well as from Oita Prefecture community leaders. He put his main effort into campaign rallies, holding perhaps 70 or 80 altogether, where he attracted crowds averaging between 70 and 150 listeners throughout his campaign. This turnout convinced Noyori that he was far ahead of all rival candidates in Oita's First District. Local newspapers shared his optimistic assessment. ${ }^{6 \overline{5}}$

As the campaign progressed, Noyori's tone became progressively more critical. In March he had bemoaned that candidate standards were too abstract, and by April he complained about the dull and dispirited election. ${ }^{66}$ Although describing himself as a "wholehearted supporter" of Tojo's cabinet, as the election campaign wore on, so did Noyori's temper. Police censored his newspaper four times when he tried to publish articles implying government interference occurred or intimated that collusion between the Military Affairs Bureau and the Tojo government would result in only the election of recommended candidates. ${ }^{67}$

Noyori's optimistic appraisal of himself as the first or second place contender seemed realistic for the press considered the two recommended new men's elections doubtful. Then, coincidentally concurrent with the Political Council's final, coordinated campaign blitzkreig, 
the local police chief intervened and requested community leaders to refrain from any endorsement of Noyori that might damage new, recommended candidates' election chances. If they did make such endorsements, the police chief threatened "to expose" Noyori's faction. Furthermore, police disregarded Keibödan members' campaigning on recommended candidates' behalf and, on election day, these latter day söshi (political bullies) shouted from the village office's second and third story windows to voter queues below to "Vote for recommended candidate _-."

Dirty tricks also hampered Noyori's comeback bid. At an April 23 evening rally, a false air raid report forced a temporary blackout of Noyori's rally. When the lights went back on and the rally resumed, only 12 or 13 of the original 50 listeners returned. He blamed "political opponents" for this unscheduled interruption.

As fifth place runnerup, Noyori personally attributed his defeat to the popular misconception that the Political Council and the IRAA were related associations. This led voters to regard independents like himself as IRAA and government opponents. ${ }^{69}$ His articles also continually alluded to his naive confidence in Tojo's word that the election would be impartial. Noyori misplaced his faith. Indeed, after his defeat he complained that the Tojo government should have acted morally when supervising the election and because of his increasingly bitter anti-Tojo polemics, the following year the Home Ministry ordered his Teito newspaper to cease publication. ${ }^{70}$

A combination of police and local association interference plus a coordinated Political Council campaign defeated Noyori. Police interference alone did not throw the balance against him. The Political Council's campaign strategy, specifically designed in its last stage to help recommended candidates who seemed in danger of defeat, mobilized powerful local support against Noyori just when coincidentally the police began to intimidate community leaders. Their common ends using unrelated means hurt Noyori at the campaign's critical period. His campaign does illustrate the obstacles that independent former parliamentarians had to overcome in 1942 to be elected. Only eight of 49 such candidates could do so. 


\section{Campaigning as Usual}

Miyake Shoichi himself described his 1942 Niigata Third District campaign as not much different than his previous three election campaigns, the latter two of which he won. As a candidate of nonmainstream political parties, the Zenkoku rōnō taishütō (National Workers and Farmers Masses Party) in 1932 and the Shakai taishūtō thereafter, Miyake was a seasoned campaigner whose left wing politics conditioned him to expect official harassment as a political fact of life.

Niigata exemplified the swelled candidacy numbers as 35 men contested 15 Diet seats compared to only 23 candidates in the 1937 election. So-called "new men's" absence among the district's recommended candidates caused a lack of voter support for the election campaign and for the Political Council. Niigata's jiban were also famous as was its tradition of re-electing incumbents, so even independent incumbents like Miyake were formidable opponents for political newcomers. $^{71}$

Entering his seventh year in the Diet, Miyake had constructed a durable jiban by providing for his constituents' needs, especially by bringing additional health care, a hospital, and improved school facilities to his district. Consequently, he enjoyed the support of friends, relatives, and political backers in the region. He relied on the campaign rally and tailored his campaign speeches to meet his audiences' needs. That mainly meant concentrating on the farming villages' problems because these places provided him with his strongest support. $^{72}$

His election campaign was free from any open prefectural interference, although local police disrupted his campaign speeches and harassed his election committee members. Based on his past experiences, however, Miyake did not consider such events unusual or indeed any more severe than in his previous election campaigns. ${ }^{73}$ Count Arima Yoriyasu, the former IRAA director accused of harboring leftist ideas, was Miyake's most prominent supporter and journeyed from Tokyo to lend his talents to Miyake's campaign. Police did not order cautions or suspensions in great number, but did caution one speaker for offering personal inducements for votes when he reminded an audience that Miyake had been instrumental in bringing a hospital to the area. ${ }^{74}$ Generally, the police were impartial toward both rec- 
ommended and independent candidates alike, a condition that Miyake attributes to the prefectural governor's attitude. ${ }^{75} \mathrm{He}$ also believes that the prefectural authorities thought that he would be defeated anyway, so they redoubled their efforts against more promising candidates and ignored him.

Local Tōhōkai candidates, in contrast, did meet strict police supervision. The IRAA and the Adults Association actively campaigned for recommended candidates while obstructing independent ones. In the neighboring Second District, both organizations meddled in former Socialist Masses Party member Ii Seiichi's (1892- ) first national campaign. In more northern Akita Prefecture, former Shakai taishütō central executive committee member Kawamata Seion (18991972) found himself the object of thought police investigation and a special report to Home Minister Yuzawa for having the termerity to tell campaign crowds to take care of their own interests before worrying about national policies. ${ }^{76}$

Miyake though worked unceasingly throughout what he termed a "hot-blooded" (chinoke-ga-oi) campaign while his recommended opponents, somewhat like Tsukui Tatsuo, became overconfident and waged uninspired insipid contests. Miyake finished first in his constituency and owed his success to being a well-known incumbent (he had a jiban) whose active campaign capitalized on recommended candidates' underestimating his jiban resources. A lack of interference also permitted him to develop a winning campaign. The February police investigation rated Miyake "undesirable" as a Diet member, yet he not only easily won another term but also got the most votes in his constituency.

This suggests that election interference depended on prefectural officials' initiative. It also shows that campaign conditions varied widely, from the overt interference in Nagasaki, to the more subtle manipulation in Gunma, to the lack of interference directed against Miyake in Niigata. For Miyake, the 1942 election was an impartial election in which voters selected candidates of their choice rather than any handpicked Military Affairs Bureau or Tojo-approved flunky.

\section{The Impossible Campaign}

A record number of candidates, chiefly due to the presence of 432 
new, independent office seekers, characterized the 1942 election. The dismal showing of these new men, of whom only 30 won elections, resulted from political inexperience, public indifference to their campaigns, or interference. Perhaps the most important factor in their defeats was the extreme difficulty of getting elected to anything in Japan without organized backing in the form of a political party or Political Council, or in 1942, from a jiban developed during the prior party politics' era. Shimomura Eiji's campaign in Kagoshima's Second District points out all these obstacles.

Even under ideal conditions, Shimomura faced a herculean task. Nine opponents vied for the district's four seats, including three incumbents (two recommended, one independent) and four others who had previous affiliations with the defunct political parties. Unfortunately for Shimomura, instead of ideal conditions in Kagoshima Prefecture, it was the place where election interference was at its very worst during the 1942 election.

Kagoshima was a predominantly rural prefecture, condescendingly described as the most politically backward area in all Japan. Its governor took the government line literally and exerted pressure on community leaders to support only recommended candidates. A strong Adults Association chapter added its weight to the recommended candidates' campaigns. Community leaders in turn mobilized the electorate who would perform as their local chiefs directed. Kagoshima might qualify as the prototype for proper voter participation in a show election.

Allegations against the prefectural Kagoshima authorities read like an election interference primer. Local school principals used public associations like neighborhood association meetings to denounce independent candidates as traitors who opposed the imperial will because, in circular logic, a recommendation was in accordance with the imperial will. As traitors, independent candidates' children and even grandchildren should, arguments ran, be excluded from public employment! Adults Association village level organizational directors conspired to convoke special meetings and projects to coincide with independent candidates' rallies, and thus prevent voters from attending. A police officer told a local farmers' meeting that independent candidates had "red ideas," so everyone had to support recommended 
candidates. One enterprising police chief told neighborhood association members in his district that, if even a single independent candidate were elected, their headman would have to kill himself in atonement. Luckily, the headman was not put to the test, but one wonders if it was his idea or the police chief's in the first place. Additionally, neighborhood association members who failed to attend recommended candidates' campaign rallies would be reported to the police. The prefectural governor endorsed recommended candidates in a letter that he sent to all prefectural community leaders while the Adults Association, the Reservist Association, and the police all campaigned openly for recommended candidates. On election day, the police tried to intimidate voters by blocking the entrance to polling stations, by interrogating potential voters, and by instructing voters to select recommended candidates. Adults Association members also joined in this voter harassment. ${ }^{77}$

Shimomura felt that he was not recommended because he had no personal acquaintances or ties with either the national government or the prefectural authorities. ${ }^{78}$ His troubles began early and continued throughout the entire campaign. Officials scheduled special neighborhood association meetings that, by prearrangement, coincided with his campaign rallies or potential voters might be mobilized for road repair and forest clearing, usual tasks, but set to overlap the times of Shimomura's rallies. Even if he did manage to collect an audience, his evening rallies proved tumultuous because Adults Association toughs on motorbikes surrounded the rally grounds and tried to intimidate persons going to the meeting.

Added to this the fact that Shimomura was a political neophyte lacking a jiban and organized backing made his chances of election nil. His own inadequate resources combined with the open interference directed against independent candidates throughout Kagoshima Prefecture overwhelmed him as well as the other independent candidates there. Shimomura's disastrous showing (he tallied a mere 264 votes out of over 100,000 ) clearly indicates that his election would have been extremely doubtful even in the most scrupulously impartial election. In that sense, he was typical of the approximately $25 \%$ of "new men" who failed to attract sufficient votes and consequently had their election bond confiscated. His campaign is interesting in itself 
as an example of naked government interference directed against an

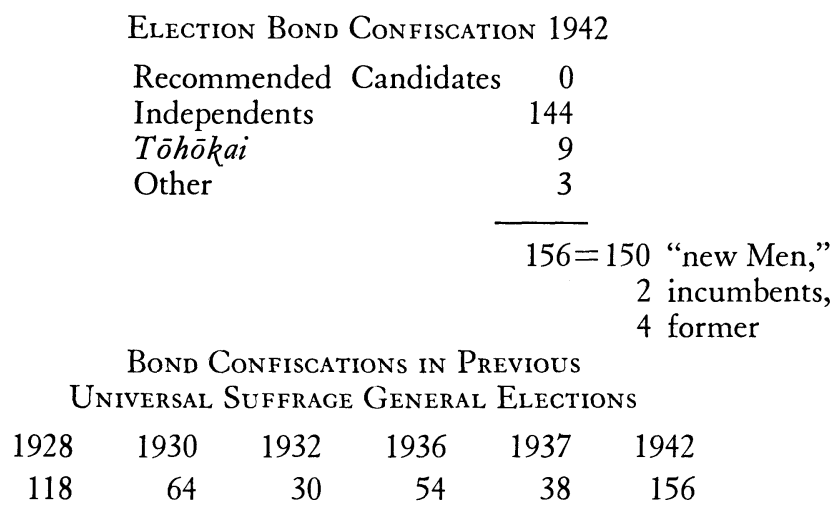

Source: Maruyama Sei, "Senkyo memo" (Election Memo), Shūkan Asahi, (May 17, 1942), 12-13.

independent candidate but it becomes more meaningful by reason of his post election activities. After the election of only recommended candidates in Kagoshima Prefecture, the defeated independents took their case to court.

Four Kagoshima Second District defeated candidates, Shimomura included, brought indictments that the election should be declared void because of the massive interference. A Civil Affairs Bench investigation into the conduct of the election was figuratively under fire due to the Kagoshima prefectural police and authorities' uncooperative attitude, and, as the inquiry neared completion, literally under fire by hedge-hopping American fighter aircraft operating over southern Kyushu. ${ }^{79}$ As a result of these investigations, conducted at risk of life, limb, and reputation, on March 1, 1945 the Civil Affairs Bench's Third Session declared Kagoshima's Second District election null and void and ordered a rerun. ${ }^{80}$

All concerned parties accepted this judicial decision and held a rerun election on April 20, 1945. It is true that the rerun did not change the initial results. The significant point, however, remains that a court issued an essentially anti-government order and the government implemented it. As in the Ozaki case, governmental authorities abided by the court decision, unpalatable as it must have been, which reinforces the interpretation that the rule of law still operated in wartime Japan even as military defeat loomed everywhere. 


\section{Interference in Perspective}

The preceding examples of electioneering are useful in analyzing the problem of interference in the 1942 general election. The salient feature of electoral interference in 1942 was the widespread disparity in its application. Election interference appears to have been mainly conditional on the particular prefectural officials', especially the governors', attitude. When governors actively conspired against independent candidates as in Kagoshima, Nagasaki, and Gunma, prefectural interference was pronounced and decisive as only recommended candidates won election. However, in areas like Tokyo and Niigata, where the prefectural authorities acted more impartially, the election results reflected a mixture of both recommended and independent candidates winning election. Any direct equation of recommended candidates' election with illegal interference cannot be made due to the presence of an incumbent majority among recommended candidates who may simply have been re-elected on the basis of their incumbency and previously constructed jiban.

The contradiction between constitutionalism and illegal election interference appears to substantiate the "failure" thesis of pre-war Japanese parliamentary politics. If political modernity may be gauged only in terms of whether or not an alteration of power took place via elections, then Japan, of course, never modernized politically because Japanese elections were meant to confirm, not to transfer, power. In its historical context, election interference in 1942 was not innovative; instead, it adhered to traditional forms of election obstruction.

Prior to 1942, there were three great examples of election interference, the 1892, the 1915, and the 1928 general elections. Interference motivations differed in all three, but interference forms were strikingly similar. The 1892 election was the most notorious in Japanese constitutional history. Home Minister Shinagawa Yajirō ordered prefectural governors to insure the defeat of political party candidates and the election of government party men. Armed with this carte blanche, police canvassed for votes, intimidated voters, condoned vote buying by pro-government candidates, and even presided over a small war in Kochi Prefecture between rival political factions. The human toll nationwide was 25 dead and 388 injured, although 
unofficial estimates were much higher. The object of such interference was to crush the nascent political party, the Jiyut to (Liberal Party) and to promote the Chīo kurabu (Central Club), a pro-government party. The result, despite the interference, was that 163 Jiyñto versus 137 Chīo kurabu were elected and Shinagawa had to resign under pressure. Moreover, all governors did not obey the Home Minister's injunction. The Akita governor, for example, believed that interference detracted from the public ability to select "true representatives" and, consequently, ignored Shinagawa's orders. ${ }^{81}$ Interference then failed.

The second instance of large scale electoral interference occurred in the 1915 general election when Prime Minister Ōkuma Shigenobu (1838-1922) employed massive police interference to try to create a second major political party to oppose the Seiyūkai. Wholesale shifts involving 16 retirements and 35 transfers of governors preceded the election, and during the election the police restricted Seiy $\bar{u} k a i$ candidates while ignoring violations by the pro-government Rikken doshikai (Constitutional Comrades Society). Accused of election law violations, Home Minister Ōura Kanetake (1850-1918) resigned a week after the election. Ten Diet members were indicted on bribery charges, and Ōkuma's government, despite electing 153 Dōshikai candidates and reducing Seiyükai deputies from 188 to 108, faced a severe public reaction to its overt interference that ultimately forced Ōkuma's resignation. Another election followed just two years later and that election, not incidentally, was a resounding Seiy $\bar{u} k a i$ triumph. ${ }^{82}$

The third major incidence of election obstruction happened in 1928, the 16th General Election and Japan's first universal male suffrage election. Once again, shifts of prefectural officials preceded the campaign. The difference this time was that a political party Home Minister, the Seiyūkai's Suzuki Kisaburō (1867-1940), led the interference. The Police Bureau, also controlled by the Seiyzukai, ordered its officers to suspend campaign rallies "when speakers slander the election by suggesting election interference by the government." ${ }^{83}$ Suzuki also ordered strictest supervision of Minseito candidates and used police election intelligence to help lagging Seiyükai members' campaigns. Seiyükai candidates also received a classified Police Bureau document that explained methods of evading the election laws. ${ }^{84}$ 
However, as in the past, the results were not one-sided. The Seiyükai elected 217 candidates, but the Minseito elected 216. Moreover, Suzuki, the Police Bureau Director, and 10 governors were accused of election interference. Suzuki had to resign and, profiting from a popular backlash, the Minseito won an overwhelming victory at the polls two years later.

In 1942, 381 recommended and 85 independent candidates were elected. Government interference at the prefectural level was in certain instances, but not all, decisive in the election of candidates. Dókokai leader Hatoyama Ichirō, for example, found himself temporarily detained by the police following the suspension of one of his rallies. Police also arrested Hatoyama's supporters after suspending another of his rallies. ${ }^{85}$ Likewise, "almost all" of Dōkōkai candidate Andō Masazumi's 30 rallies were ordered dissolved, it being rare if one ended without incident. ${ }^{86}$ Dōkōkai candidates alleged more blatant interference in Gunma, Wakayama, Tōyama, Hiroshima, and Nagasaki.

Nationally, Adults Association, Reservist Association, and Keibōdan members canvassed for votes for recommended candidates. These groups in Kobe assailed Saitō Takao as a traitor and pacifist and otherwise tried to disrupt his rallies. Police confiscated Saitôs campaign literature. $^{87}$ In Kyoto, Ashida Hitoshi contended that police also confiscated his campaign literature, harassed his supporters, and that Adults Association bullies disrupted his campaign rallies. Additionally, the Kyoto area regimental commander denounced his candidacy as treasonous. In Niigata, police arrested Dóksokai candidate Kita Reikichi (1885-1961) and prosecutors indicted him for allegedly spreading rumors during his campaign. Independent Kawamata Seion, the object of thought police attention, campaigned under close police supervision. Nevertheless, despite these clearly illegal obstructions, all of the above named candidates won re-election. ${ }^{88}$

Prefectural authorities, especially the governors, led the local police and government interference against independent candidates. They used the police power as it had been used in the past, to try to affect decisively the election's outcome. Legal recourse for victims, however, did exist. The election was neither free nor completely controlled. Instead it followed a previously established pattern of Japanese gen- 


\section{GENERAL ELECTION}

By governors:

Soliciting votes; Interfering in campaigns of specific candidates.

\section{By Home Minister \&}

No direct connection apparent, but strict enforcement of election regulations is ordered. Orders restricting rally topics are issued.

\section{By Police officers:}

Interference at polling stations; Solicitation of votes; Intimidation of voters; Ignoring campaign violations by recommended candidates, but strictly enforcing all laws against independents. Candidates arrested.

\section{General:}

Newspapers prohibited from publishing certain topics; Independent candidates equated with traitors who offend the imperial will.

\section{Adults Association \& IRAA members harass $\&$ intimidate voters.}

Extravagant, illegal campaign funds.

\section{GENERAL ELECTION}

Soliciting votes; Interfering in campaigns of specific candidates.
1892 GENERAL ELECTION
Soliciting votes; Interfering in campaigns of specific candidates.

Home Minister orders governors to work for the defeat of Liberal Party candidates.

Interference at polling stations; Solicitation of votes; Intimidation of voters; Ignored, or even abetted interference at polling stations; Arrest of candidates.

\begin{abstract}
Interference at polling stations; Solicitation of votes; Intimidation of voters; Overlooking, and in certain cases, explaining to candidates how to evade election laws; Police investigation of election conditions used by government to help weaker candidates.
\end{abstract}

Newspapers prohibited in mid-campaign from publishing certain topics; Minseitō candidates equated with traitors who offend the imperial will.

Po'itical bullies used by both major parties.

Extravagant, illegal campaign funds.
Newspapers prohibited from publishing certain topics; Liberal Party candidates equated with traitors who offend the emperor.

Sōshi (political bullies) harass \& intimidate voters.

Extravagant, illegal campaign funds.

eral elections in which government interference influenced some, but not all, election contests.

As a generalization, the Tojo government either led or condoned election interference mainly against Dōkōkai, Tōhōkai, and former 
Socialist Masses Party candidates because they had the best chances for election among independent candidates. Interference forms were consistent with past precedents indicating that the prefectural governor was the key to the degree of interference in each candidate's case. As the authority on the spot, the governor's influence could be the decisive ingredient in an election. If, however, the governor went too far, he risked a political backlash and legal action such as occurred in 1892, in 1915, in 1928, and again in 1942.

In that context, the prefectural authorities' interference was a part of the electoral process' demimonde as were vote-buying, election brokers, and election obstruction. Interference was cyclical in nature, but always simmered just below the thin crust of legality provided by the constitution. The shadowy world of election fixers and manipulators also, unfortunately, seems generally to be a permanent feature of the democratic electoral process. From the rotten borough of parliamentary Great Britain to Watergate, there have always been those who have attempted to use elections for personal gain instead of an expression of the popular will. Perhaps a comparative study of this aspect of popular elections might provide a more accurate measure of "political modernity" or of the validity of the so-called "failure of parliamentary politics in Japan." 


\section{Chapter VII \\ The Hollow Victory}

\section{Election Results}

The 1942 general election was a superficial government success. Over 12 million of the nearly 14.6 million eligible Japanese voters trooped to the polls and cast almost eight million votes or $66.3 \%$ of the total for recommended candidates, while just over four million voted for independents. ${ }^{1}$ Prefecturally, voting percentages for recommended candidates ranged from highs of over $84 \%$ in the politically conservative backwaters of Iwate and Kagoshima to a low of $44.6 \%$ in Aomori where the public had been particularly apathetic about the campaign, possibly because the incumbents were the majority of recommended candidates. $^{2}$ There were very few invalidated ballots, only 2,597 in all. Among these, some 20\% complained about food shortages, $15 \%$ assailed the election with graffiti like, "A sponsored election makes fools of the people," "Japan's first trick election," and "The police are the recommended candidates' campaigners." Another two percent complained about the Doolittle Raid by criticizing Tojo for compaigning during wartime or reproving the military who "contemplate while enemy planes attack!" One anonymous voter even preferred Doolittle to Tojo as he scrawled on his ballot, "North American Aircraft, Banzai!" In universal suffrage elections since 1928, the voter absentee rate of $16.8 \%$ in 1942 was lower than any except the $16.7 \%$ in the 1930

\begin{tabular}{|c|c|c|c|}
\hline \multicolumn{4}{|c|}{$\begin{array}{l}\text { Voter Absentee Percentages for } \\
\text { Universal Male Suffrage Elections }\end{array}$} \\
\hline 1928 & $19.7 \%$ & 1936 & $21.3 \%$ \\
\hline 1930 & $16.7 \%$ & 1937 & $26.7 \%$ \\
\hline 1932 & $18.3 \%$ & 1942 & $16.8 \%$ \\
\hline
\end{tabular}

Absentee Rate in Major Cities in 1937 and in 1942

1937

$\begin{array}{lll}\text { Tokyo } & 37.8 \% & 14.0 \% \\ \text { Kyoto } & 36.1 \% & 18.9 \% \\ \text { Osaka } & 46.3 \% & 24.9 \% \\ \text { Yokohama } & 30.8 \% & 21.0 \% \\ \text { Kobe } & 28.7 \% & 17.5 \% \\ \text { Nagoya } & 24.2 \% & 15.2 \%\end{array}$

Source: Naimushō keihōkyoku, "Shūgiin giin sōsenkyo no gaikyō" (Aspects of the General Election for the Lower House), Naimu kōsei jihō (July 1942), 4-5. 
general election. ${ }^{4}$ A genuine surprise was the near record turnout because, based on the low campaign rally attendance, political analysts had expected a much higher absentee rate.

Contemporary journalists explained the vast voter turnout, as opposed to the poor crowds at rallies, as a function of the labor shortage. While hard work and long hours, especially in rural areas, had precluded people attending campaign rallies, voting required less time and consequently did not interfere with other work. Secondly, the record number of candidates had apparently diminished the available audience since it was physically impossible to attend every campaign rally or, in the case of Tokyo's Fifth District, to attend more than a handful of rallies conducted by the 25 candidates. ${ }^{5}$ Thirdly, there was ideal weather nationwide on election day. Fourthly, in retrospect, observers pronounced the enlightenment campaign a success. ${ }^{6}$ Other reasons suggested for the overwhelming turnout were candidate balance, "impartial" election regulation, and the IRAA, Adults, Reservist, and Greater Japan Women's Associations' as well as neighborhood associations' role in getting out the vote. Several Japanese historians maintain that these latter activities amounted to forcing voters to cast ballots or to face recriminations. ${ }^{7}$

These historians point out that non-voters had to provide their reasons, in writing, to their respective neighborhood association leaders. A special form devised for this purpose required the abstaining voter to record personal information (age, address) and his reason for not voting, categorized as due to travel, illness, or other. ${ }^{8}$ According to Home Ministry statistics, however, neighborhood associations employed this format in only five prefectures besides Tokyo, ${ }^{9}$ meaning that in 41 prefectures voters did not have to explain in writing their failure to vote. Neighborhood associations did exert peer group pressure on their members to vote and neighborhood billboards urged voters to go to the polls in 13 prefectures while members in 10 others vowed to vote or issued identification slips to indicate those who had voted in 21 prefectures. Characteristic of the entire campaign, standardization was lacking. Peer group pressure and certainly some coercion existed, but it seems likely that most voters cast their ballots because they wished to demonstrate their political choice via the ballot box. No one tampered with ballots and, based on election interference indictments, 
only in rare instances did the police or political toughs try to coerce or to intimidate voters at the polling stations.

The Japanese press was effusive in its praise. The Nichi Nichi termed the election a "considerable success" that, by striking a blow at the former party jiban, allowed men of national outlook to be elected. An Asahi editorial also believed that the old political jiban was dead and that the election showed beyond any doubt the Tojo government's firm base of support. With the election as the first stage, a yokusan Diet for national renovation would presently be established. The Yomiuri, elated by so many political newcomers' success, also saw the death of jiban. It was true that "not a few" old style politicians remained, but Diet renovation, the election's fundamental premise, had been accomplished. The elected "new men" would form the nuleus of the Diet's "new order" and, working with re-elected incumbents, who would, of course, have a yokusan consciousness, would reform the Diet. $^{10}$

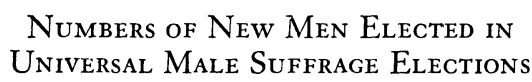

$\begin{array}{ccccc}\text { Year } & \text { New } & \text { Incumbent } & \text { Former } & \begin{array}{c}\text { Total } \\ \text { Candidates }\end{array} \\ 1928 & 173 & 244 & 49 & 965 \\ 1930 & 125 & 282 & 59 & 840 \\ 1932 & 122 & 275 & 69 & 779 \\ 1936 & 125 & 272 & 69 & 879 \\ 1937 & 81 & 346 & 39 & 826 \\ 1942 & 199 & 247 & 20 & 1,079\end{array}$

Source: Inoue, "Yokusan senkyo o tsuku, 2," 36-38.

Political Council members also crowed about the election results because they raised morale, united homefront opinion behind the war effort, and placed almost 200 "new men" in the Diet as successful recommended candidates. General Abe, avoiding any further blunders, expressed his thanks and appreciation to the Second National Branch Chiefs Convention that opened in Tokyo on May 4 and that officially dissolved the Council on May $6{ }^{11}$ Having served its purpose, the Political Council could be disbanded. This meant, however, that there was no longer any national political association in Japan.

An elated Prime Minister Tojo informed a May 2 national radio audience how pleased the government was that the election had been 
conducted fairly and had further strengthened homefront unity. Election results, according to Tojo, proved to Japan's allies the Japanese people's "unflinching determination" to fight the war to a successful conclusion. Now, he continued, the election was over, but he would still serve the emperor by prosecuting the war effort backed by the entire nation. ${ }^{12}$

\section{Winners and Losers}

Election results seemed to justify such optimism. Among recommended candidates 381 (169 new, 200 incumbents, and 12 former parliamentarians) won election from the 466 entries (213 new, 235 incumbents, and 18 former) or $81 \%$. Recommended incumbents showed the best election ratio, $85 \%$ (200 of 235), while recommended newcomers trailed only slightly at 79\% (169 of 213), and 67\% of former members (12 of 18) were also elected. Among unrecommended candidates, $35 \%$ of incumbents ( 47 of 132) won re-election, but unrecommended newcomers, lacking Political Council support or jiban, managed a paltry seven percent, electing just 30 of 432 candidates. Former members who were not recommended fared slightly better at $16 \%$ (eight of 49 ).

Results of the 1942 General Election by Faction

$\begin{array}{lcccc}\text { Faction } & \text { Incumbents } & \begin{array}{c}\text { Elected/ } \\ \text { Recommended }\end{array} & \begin{array}{c}\text { Elected/ } \\ \text { Independent }\end{array} & \text { Total } \\ \text { Yokudo } & 308 & 175 / 204 & 21 / 59 & 196 / 263 \\ \text { Dókōkai } & 34 & 0 & 9 / 28 & 9 / 28 \\ \text { Kóa giin kai } & 27 & 5 / 5 & 6 / 18 & 11 / 23 \\ \text { Giin kurabu } & 15 & 8 / 10 & 1 / 3 & 9 / 13 \\ \text { Tóhökai } & 4 & 0 & 7 / 47 & 7 / 47 \\ \text { Unaffiliated } & 40 & 5 / 13 & 8 / 23 & 13 / 36\end{array}$

This infusion of political newcomers had its corollary in which incumbents they replaced. Before the election there were 38 Lower House vacancies and 45 Yokudo, two Giin kurabu, eight independents, and six Dókōkai members either retired from politics or opted not to run in the 1942 election thus creating 61 additional open seats, or 99 total. Of the 308 Yokudo members, 263 ran and 196 were elected (204/175 recommended, 59/21 independent), a net loss of 112 seats. The Giin kurabu lost six seats, the Köa domei 16, and the Dōkōkai 19. Altogether 105 incumbents lost their re-election bids. The 199 new men 
in turn may be seen as replacing these 204 (99 open, 105 defeated) parliamentarians. About half these losses were Yokudo freshman and sophomore members whom the Yokudo leadership sacrificed during the recommendation process. The remainder were Yokudo opponents from the Dōkókai or Köa giin kai. "New men" replaced about 100 defeated incumbents, but not the former political party leaders. In fact, the average age of representatives, in an election ballyhooed as one to infuse "fresh, new talent" into the Diet, actually increased from 53 years seven months to 54 years two months. ${ }^{13}$

\begin{tabular}{|c|c|c|c|c|c|c|}
\hline \multicolumn{7}{|c|}{ Average Age of Lower House Representatives } \\
\hline Age Group & 1942 & 1937 & 1936 & 1932 & 1930 & 1929 \\
\hline 30-39 & 15 & 25 & 22 & 22 & 20 & 28 \\
\hline $40-49$ & 135 & 136 & 124 & 158 & 168 & 172 \\
\hline $50-59$ & 195 & 192 & 197 & 193 & 167 & 165 \\
\hline $60-69$ & 103 & 86 & 97 & 83 & 104 & 91 \\
\hline $70-79$ & 16 & 27 & 26 & 10 & 7 & 9 \\
\hline $80-89$ & 2 & & & & & \\
\hline Average 5 & 54 yrs. 2 mo. & $53-7$ & $54-3$ & $52-6$ & $52-7$ & $51-9$ \\
\hline
\end{tabular}

Source: Senkyo no jiseki, 165-169.

Among former party leaders and their lieutenants, Nakajima, Machida, Maeda, Nagai, Shimada, Kiyose, Yamazaki, and even Hatoyama and Ozaki as independents won re-election with comparative ease. The most conspicuous losers among so-called "established parliamentarians" were Tawara Magoichi (1869-1944), a former Communications and Industry Minister in the Hamaguchi Cabinet; Dōkōkai members Tagawa Daikichirō and Hyōgō Fifth District sixth termer Wakamiya Sadō (1875-1946); and Haraguchi Hatsutarō (1876-1949), a retired lieutenant general and formerly on the Seiyükai Directorate, a third termer in Fukuoka's First District. Only two prominent Yokudō figures, recommended Tawara and independent Nomura Karoku (1893-1952), a tenth termer formerly on the Minseito directorate, lost. Other significant losers included the former Socialist Masses Party members who elected only 13 of 40 candidates, including five recommended ones, and who polled about 460,000 votes as compared to over 920,000 in the 1937 general election. ${ }^{14}$

The right wing's myriad forces, although electing more representatives than ever before, had to assess the 1942 election as a bitter failure. Among reform and traditional rightists, 28 recommended and 21 inde- 
pendent candidates were elected. ${ }^{15}$ These 49 seats, although they should not be thought of as a single, unified voting bloc, represented a tripling of seats the right held compared to the 1937 results. However, over five times the number of reform rightists (196) ran for election as in 1937. The Töhökai ran 47 candidates yet elected but seven and all 37 Rikken yōseikai candidates lost. Those 49 elected "orthodox" reform rightists (21 independent) received slightly more than one million votes and another 34 candidates (five independent) whom the police described as merely "nominal" (non-activist) reform rightists also won, securing a little over 575,000 votes. Most "nominal rightists," 23 in all, had affiliations with Ishiwara Kanji's Töa renmei doshikai and they amassed nearly 450,000 votes or $79 \%$ of all "nominal rightists" " totals. Rightists, according to police tabulations, added 34 seats to their Diet total, but ran 245 candidates among whom 196 were from the reform right camp. In the previous general election, only 38 reform rightists had entered, but their numbers increased fivefold in 1942. Moreover, police reported reform rightists' unrest for contrary to their expectations the election did not throw the government and the domestic political scene into turmoil thus creating the chance for them to seize power. Despite recommended candidates' crushing, landslide victory, all was not peaceful in the Japanese political world.

By May other sources of election criticism began to appear. One political authority sarcastically observed that while the election's goal was to elect new Diet men, the Political Council had merely perpetuated Yokudo rule. The presence of so many re-elected Yokudo incumbents in the Diet accordingly reduced the possibility of renovating that institution. ${ }^{16}$ Moreover, critics singled out Adults Association election activity for censure on the grounds that the association had used the campaign to advance its own, not national, interests. ${ }^{17}$ There were open charges that the Adults Association, dissatisfied with a limited enlightenment campaign role, unilaterally criticized "old style candidates" and even, in some instances, denounced recommended candidates whom its leaders identified as "old style" mainstream Diet politicians. Such activity reinforced the image that association members had "run wild" during the election campaign. ${ }^{18}$ The election's bitter residue of resentment against the government and the Political Council appeared clearly in the reform rightists' camp. Dōkōkai members, 
however, were also busy filing indictments alleging government sponsored election interference and other defeated candidates like Noyori Hideuchi were in no mood for further sugar-coated homefront unity rhetoric. Despite such widespread discontent, however, the paradox remains that all political associations in Japan did dissolve and almost all Lower House members did join the Yokusan Political Society (Yokusan seijikai), the new political association that the Tojo government created on May 20, 1942.

\section{The Imperial Rule Political Society}

Like much in Japan, form belies substance. The IRAA appeared to be a monolithic political party but, in fact, was a multifarious public association forbidden by law to participate in political activity. The so-called Yokusan Diet of 1940-1941 (76th Session), instead of providing homefront unity according to form, produced widespread domestic discord over the IRAA's status. So too with the Political Society. As the sole political association in Japan after May 1942, it appeared to be the culmination of "one-nation one-party" theorists' goals. A closer inspection of the association's goals and later tribulations dispels the notion that the Political Society functioned as a monolithic political body, particularly in the Diet's Lower House.

Tojo hoped to capitalize on the election results and accordingly prepared post-election plans for "concentrating" political power in a new political organization to be headed by General Abe Nobuyuki. ${ }^{19}$ In order to achieve this objective, on May 7 Tojo invited 70 men representing the political, financial, and opinion communities to his official residence and requested their assistance in consolidating domestic political power to realize homefront unity. Among these 70 representatives, 32 of the 33 former Political Council headquarters personnel and 29 business and opinion sector delegates were present. ${ }^{20}$ The delegates agreed among themselves to form the inevitable Preliminary Committee for the Concentration of Yokusan Politics (Yokusan seiji $k e s s h \bar{u}$ junbikai) whose deliberations resulted in the Yokusan Political Society's inauguration. ${ }^{21}$

Over 950 sponsors endorsed the Political Society, including 338 Peers, 425 Lower House representatives, 53 IRAA officials, 45 former Political Council branch chiefs, and 43 Reservist, IRAA, or former 
Political Council members. In accordance with the Police Public Safety Law, imperial family members, active duty military men, and others forbidden to join political organizations as well as eight Lower House members then under indictment for alleged election violations, were excluded from the new association. Tojo appointed General Abe the director and, in his inaugural address, Abe told the assembled delegates that the Political Society was neither a political party rooted in conflict like American or European models nor was it a "one-nation one-party" dictatorship's tool. Abe, who had a knack for ambiguity, instead characterized the Society as Japan's own unique political creation. ${ }^{22}$

The new society's charter did not clarify his nebulous remarks. Its aims were:

Based on kokutai principles, to concentrate political power for the Greater East Asia War's prosecution.

Based on loyalty to the Constitution, to anticipate a Yokusan Diet's establishment.

Based on close liaison with the IRAA, to anticipate a thorough yokusan movement through mutual cooperation.

Based on the Greater East Asian Co-Prosperity Sphere's establishment, to anticipate a new world order's construction. ${ }^{23}$

During the preparatory meetings leading to the Society's creation, Japanese political associations and parties began to dissolve themselves in a manner reminiscent of the 1940 pre-IRAA stampede to disband the existing political parties. The Dōkōkai, for example, dissolved on May 14, closely followed by the Yokudo five days later. The Tōhōkai, still seething with recriminations over its disastrous election campaign, bowed to the inevitable and disbanded itself on May 23 while Akao Bin's Kenkokukai and Hashimoto Kingorō's Sekiseikai also broke up as political associations. Furthermore, 456 of the 466 Lower House representatives and members of the aforementioned disbanded associations joined the Political Society. ${ }^{24}$ Among Peers, all but 18 entered the Society, although the existing Peers' clubs, which performed that chamber's management function, as fraternal in nature, were not required to disband. Instead, each club dispatched a representative to the Society. Overall, the Society seemed to enjoy bicameral Diet support.

A General Affairs Committee composed of 29 members (14 perma- 
nent), including Katsu Masanori, Ōta Masataka, Ōasa Tadao, Nagai Ryutarō, Maeda Yonezō, and Yamazaki Tatsunosuke ran the Political Society. The same pre-election Diet leaders who had dominated the Political Council staffed the Society's highest decision making organ. They also established a bureaucratic nightmare known as the Political Affairs Investigatory Committee. It had 15 committees (one for each ministry), 31 directors, and two vice-chairmen. Its chairman, Yamazaki Tatsunosuke, supposedly maintained close liaison with the cabinet, the ministries, and IRAA-related associations to prepare presession Diet plans. He also worked with various ministry personnel to investigate and to revise planning drafts that would be submitted to the General Affairs Bureau as definitive proposals. ${ }^{25}$ The IRAA, as a public association, found itself relegated to menial nonpolitical work like bond rallies, promotion of national fitness, and increased production. Both the IRAA and the Political Society were supposed to cooperate with the government to achieve homefront unity. In reality, the Political Society followed almost exactly along the guidelines that the Yokudö's February general meeting had proposed. In short, the Political Society was expected to monopolize political power in Japan. ${ }^{26}$

Since the IRAA was to lead the public side of this equation, the Tojo cabinet decided to consolidate within it other public associations like the patriotic unions, the Greater Japan Women's Association, and the Japan Boy Scouts. It swiftly accomplished this after meeting with those associations' representatives in early June and, following an understanding reached at that conference, on June 25, those groups disbanded themselves in order to enter the IRAA. Similarly, in midJuly, the IRAA absorbed the Election Purification League and on July 17 the IRAA's Central Cooperative Committee extended its scope to encompass the community councils and neighborhood associations network. Prefectural governors, however, still remained as the IRAA prefectural branch directors. Additionally, Tojo again reorganized the IRAA as five Bureaus (General Affairs, Practical Action, Revive Asia, Training, Investigatory) replaced the existing three (General Affairs, Organization, East Asia). The newly created Investigatory Bureau's primary task was liaison with its Political Society counterpart and with government ministry committees in order to provide these committees with inputs concerning national livelihood conditions. 
It had 10 subcommittees with approximately 200 members examining matters ranging from pure science to elevating national spirit. ${ }^{27}$

An uneventful two day session of the Extraordinary 80th Imperial Diet (May 27-28, 1942) passed only four bills, none of crucial importance, and unanimously approved a vote of appreciation for the armed forces. ${ }^{28}$ The Tojo cabinet regarded this session as a success because it contributed to homefront unity by demonstrating to foreign powers the Japanese government's and people's "iron determination" to prosecute the war effort. ${ }^{29}$ Indeed, according to a secret cabinet document circulated prior to the 80th Session, the exhibition of such Diet solidarity was the government's precise goal. ${ }^{30}$ Homefront unity had seemingly been attained.

\section{Cracks in National Unity}

From the Political Society's very inception, the police cautioned government leaders not to overestimate the "external effects" of the Political Society and thereby fall victim to domestic disunity because of factional disputes among the Society's members. ${ }^{31}$ Thought police analysts expressed their anxiety about Lower House members who, while concealing their great dissatisfaction with the government's election policy, still joined the Political Society. Former 1930's party leaders like Machida Chūji, Nakajima Chikuhei, Akita Kiyoshi, and Uchida Nobuya (1880-1971), a former Seiyūkai directorate member, disapproved of the Political Society's mainstream leaders who had been these old party chieftains' political lieutenants. ${ }^{32}$ Now these one-time subordinates controlled Society affairs, leaving the old leadership with titular advisory positions (Nakajima and Machida) while consigning Akita and Uchida to serve on the Society's obscure Accounting Overseers Deliberative Council. In this sense, the 1942 election dethroned the 1930's leadership and replaced them with their former political lieutenants as Maeda, Nagai, Ōasa, Ōta Masataka, Katsu, and Yamazaki became the new Diet Lower House and Political Society power brokers.

The gravest source of police concern, however, was the reform rightists' attitude. Representatives of this persuasion claimed that the Political Society was an establishment plot to perpetuate the status quo. Police analysts warned that government overconfidence might inad- 
vertently engender the chaotic political situation that reform rightists had forecast after the election. Such conditions in turn could provide these extremists with the chance to seize power. $^{33}$ Newly elected reform rightists like Akao Bin, Sasagawa Ryōichi, and Hashimotō Kingorō continued to scorn so-called "liberal Diet elements" whose presence in the Diet, they felt, precluded a truly fresh, powerful Diet's creation. Pessimistically, thought police observed that, although all reform rightist Diet men had joined the Political Society, this amorphous group required strictest vigilance because its entire political camp was "wrapped in tendencies critical of and estranged from the Political Society." 34

Even though ultimately all but eight Lower House members entered the Political Society, this offered no cause for rejoicing to the hardheaded police realists. Quite candidly, police analysts suggested that former Dókökai members joined the Society because they realized that they could not openly oppose it. Among elected unrecommended candidates who joined, there was an air of resigned dissatisfaction. Rising conflict between the so-called new men, the Diet freshmen eager to change everything and their legislative seniors anxious to preserve their own prerogatives added another problem. In the Upper House, 18 Peers refused to enter the Society because, they believed, its existence violated the constitutionally established bicameral legislature; because it was unsuitable for Peers, the supposed "overseers of government institutions," to join a political association; and because those Peers who did join a political association were merely doing so for personal advancement's sake and thus foresaked their perogatives as Peers. ${ }^{35}$ Finally, police thought that reform rightist associations like the Tōhökai, the Kenkokukai, and the Sekiseikai had dissolved and their Diet members joined the Society because "they clearly had the idea that the government would not recognize any political association outside the Political Society." ${ }^{36}$ Those who proclaimed that a new, monolithic political party now existed to promote homefront unity for the war effort interpreted form as substance. The mundane truth, glaringly apparent to dispassionate police realists, was that such homefront unity had not been achieved.

Neither did the Political Society's new subcommittee liaison system with government ministries prove conducive to homefront solidarity. 
It faced three problems. First, deliberative sessions, theoretically the new tripod government-IRAA-Political Society-system's backbone, degenerated into elaborate affairs where members accorded overly respectful treatment to important government figures but failed to produce politically significant results. ${ }^{37}$ Second, the cabinet and the ministries subcommittee system only functioned during those few months each year when the Diet met in session and therefore found its activities accordingly reduced. Third, the committee system's functional overlap inherently contained potential conflict of interests in dealing with inter-committee affairs. Yamazaki Tatsunosuke, for instance, chaired the Society's Political Affairs Investigatory Committee and simultaneously the IRAA's Investigatory Committee plus directed (with Maeda, Ōasa, and Nagai) both the Society and the IRAA. Nagai, for his part, also remained as Revive Asia Bureau director (formerly East Asia Bureau). Disputes among subordinates on different committees chaired by the same man inevitably led to charges of favoritism. The subcommittee system was too complex to coordinate cabinet, IRAA, and Society affairs.

The Tojo cabinet, in effect, superimposed the Political Society over the Diet, the IRAA, and even the government. Ostensibly the sole political association in Japan, it failed to provide national homefront unity because a reaction among IRAA staffers and their Society counterparts occurred as both tried to protect or to expand their bureaucratic empires at the other's expense. The overlap of functions, that was supposed to allay such inter-association rivalry, really exacerbated it as chairmen like Nagai or Yamazaki became caught in the middle of squabbles between members of agencies they controlled. It also proved impossible to balance successfully the myriad associations that had just dissolved themselves to enter the IRAA. The Adults Association status within the IRAA remained unclear, and other organizations such as the Greater Japan Woman's Association and the patriotic unions also tried to retain their separate identities within the IRAA structure. Perhaps the key dispute between the Political Society and the IRAA involved the creation of regional branches for the Society.

The Political Society equivocated about expanding its influence beyond the Diet. Rank and file Diet men especially wanted to develop 
regional branches in order to maintain contact with their constituents and to construct their jiban for the next general election. The Society's directorate, however, adopted the position, as expressed by Maeda Yonezō in response to those Diet members who favored local branches, that the establishment of local branches monopolizing political power would smack of the former political parties. Instead, Maeda proposed that the Political Society and the IRAA cooperate regionally and he reaffirmed that the IRAA would direct the public while the Society guided the homefront yokusan movement's political aspect. His announcement only stimulated increased controversy within Diet ranks because it left the Political Society as a disembodied entity that divorced the elected membership from their constituents and from their jiban.

To further complicate matters, the Adults Association had just completed a powerful, if not nationally coordinated, anti-jiban campaign and Political Society leaders expected their future, vigorous resistance to the creation of local Political Society branches. ${ }^{38}$ The Adults Association, although a public association, used its role in the 1942 general election to create its own political foundation. It expanded that base considerably by its involvement in the May 1942 municipal, town, and village assembly elections when over 30,000 association members were elected to these local assemblies. ${ }^{39}$ These successes only whetted the Adults Association's political palate and did not dilute in the slightest its fundamental anti-former political party or anti-bureaucratic characteristics. In part, this accounts for the Adults Association's continued resistance to the Political Society's acquisition of a regional organization network. By spring 1943, the Adults Association boasted 47 working prefectural branches, 820 county or city ones, and 10,594 at the town and village level with $1,300,000$ members. ${ }^{40}$

Political reporters wrote of the Adults Association's regional politicization and openly criticized this tendency. ${ }^{41}$ The Adults Association should end its political maneuverings, they felt, and cease encroaching on regional political affairs as well as superseding the local IRAA. $^{42}$ General recognition existed that the regional IRAA no longer amounted to much more than its local business office while the emerging Adults Association was the political force in the hinterlands. ${ }^{43}$ 
Evidently the estrangement between the Adults Association and the IRAA was irreconcilable.

The IRAA's Third Cooperative Council (September 26-29, 1942) exhibited confusion over its future role when delegates articulated what was better left unsaid. If the IRAA lost all its political character, it would be mortally weakened, but, if the Political Society did not possess a regional organization, then its purpose would be negated locally and, consequently, the IRAA would be unable to assist the Society in consolidating homefront power for the war effort. ${ }^{44}$

\section{Breakdown of Political Society Control}

In the face of the Allied counter-offensive in the South Pacific, the perceived requirement for greater homefront unity magnified this problem within Political Society ranks. Some 290 Lower House Society members organized the Senryoku zōkyō rinji kyogikai (Extraordinary Committee to Reinforce War Potential) and demanded the IRAA and Political Society's unification. The Tojo government, however, wanted the IRAA retained in its role as an auxiliary administrative organ to implement government sponsored public campaigns. ${ }^{45}$ As the government committed itself to the existing dual IRAAPolitical Society structure, the cabinet naturally opposed any fundamental reform and refused to consider the extraordinary committee's proposal. A private instruction of November 20, 1942 made the cabinet position clear to the Political Society leaders.

Cumulatively, the proliferation of bureaucratic agencies that augmented rather than replaced existing entities increased political tensions because, as in the 1940-1941 IRAA situation, it simply papered over deep divisions with a homefront unity facade, this time in Political Society form. The Society also exacerbated regional antagonisms between itself and the local IRAA and its related associations. The government, whom police kept well informed of this unpleasant fact, faced the 81st Regular Imperial Diet Session's opening in December 1942 with an apprehension that the session proved justifiable. ${ }^{46}$

According to the Tojo cabinet, the 81st Diet's mission was to manifest one hundred million peoples' determination to prosecute the war effort. ${ }^{47}$ This required the Diet's unquestioning approval of all government introduced legislation, but the government expected diffi- 
culties to arise in the Diet over its controversial regional reorganization plan, over its intention to utilize the candidate recommendation system in the upcoming prefectural elections, and over the Tokyo City reorganization bill. In order to forestall any possible embarrassment on the Diet floor, ministerial subcommittees worked with the Political Society to deliberate in advance on the session's legal and budgetary legislation prior to its actual introduction into the Lower House. But, in order not to create the impression that the Diet had abandoned its legislative perogatives, these subcommittees decided that prefunctory public debate on the government sponsored legislation should occur in the Diet, after which the original drafts would be approved and unanimously passed unamended. ${ }^{48}$ The re-emergence of Lower House factionalism fractured these expectations.

Factions, reminiscent of pre-election days in-house negotiating groups, quickly reestablished themselves in the post-election Diet. On July 20, 1942, 199 newly elected both recommended and independent candidates formed a negotiating group, the Seishin kurabu (New Members Club) to promote their Diet interests. Dominated by rightists like Akao, Sasagawa, Sasaki, and Shioden, the club attacked liberal parliamentarians like Ozaki Yukio and pressed for Political Society local branch formation. Similarly, other "research clubs," as the police labeled them, coalesced. Seventy-five second and third termers organized the Sanjünichikai (Thirtieth Club) that, like the Seishin kurabu expressed dissatisfaction with the Political Society's existing arrangement and wished to reform it by the formation of local branches. The approximately 40 Adults Association affiliated Diet members established the Jüichi nichikai (Eleventh Day Society) expecting to use it to promote Adults Association branches as the new political base for the Political Society. The remaining eight former Dókókai members joined with Ashida Hitoshi and Saitō Takao in the Shisaikai (Like Thinkers Society) and 15 former Giin kurabu members founded the Sansui sakura gumi (Cherry Landscape Society). Largest among these sometimes overlapping "research groups" with some 258 members was the Kokumin kyoiku shinko giin renmei (Dietman's League to Promote Public Instruction), a pro-government Diet club dedicated to cooperation with government policies and dominated by the Politi- 
cal Society leaders like Maeda, Nagai, Kiyose, and Yamazaki who were League members. ${ }^{49}$

Ten days before the 81st Session opened, on December 14, 1942, Seishin kurabu and Sanjünichi kurabu members joined forces with the newly established (October 1942) Keizai giin renmei (Diet Members Economic League) composed of 261 members, mainly middle level parliamentarians, to sponsor the Yüshi daigishikai (Volunteer Representatives Association). With 106 members, the Association's goal was Political Society renovation through the establishment of a single, national, political association. Moreover, as part of this renovation, Association members demanded that the Diet General Affairs and Directorate personnel be selected on the basis of Diet management and not, as was the practice, on condition of being a Political Society General Affairs Directorate permanent member; that the Political Society's headquarters system be realigned and that its General Affairs and Directorate staffs be reduced; and that a lower level, regional Political Society organization be created. Director Maeda, on December 24 , replied that the headquarters agreed with the basic positions advocated. However, he believed that the necessity of the unification of the IRAA and Political Society being unclear and because it would interfere with the upcoming Diet business, any actual reform would have to be delayed..$^{50}$ Meanwhile, these "research groups" "maturation led editorialists to comment on the reappearance of both old and new factions in both Houses. ${ }^{51}$

The 81st Diet Session became a nightmare for the Tojo government and for the Political Society directors because disgruntled Diet members refused to be manipulated like Bunraku puppets. In the Upper Chamber, Count Ōkōchi once again questioned Tojo about allegations of widespread government interference during the 1942 general election campaign. ${ }^{52}$ Two days later, on February 6, 1943, during the Lower House Budget Committee Hearings, Satsuma Yũji (18971966), elected as a Tōhōkai candidate from Fukui Prefecture, interpellated Tojo and Yuzawa concerning the propriety of a candidate recommendation system. Sasagawa Ryoichi also heaped scorn on the candidate recommendation system. When Tojo and Yuzawa tried to dismiss the issue, their evasions met catcalls, laughter, and shouts of "Be serious!" Satsuma, his own election campaign victimized first by 
police harassment when he spoke out in favor of a redistribution of Southern Front resources and later arrested for alleged vote buying, heckled the prime minister as he told him that a popular joke in Kagoshima during the 1942 election was that even Tojo probably could not get elected running as an independent candidate. ${ }^{53}$ During the debate on city reorganization, supposedly a pro forma matter, Dietmen again attacked the candidate recommendation system and forced Tojo to admit under tough, relentless questioning that the government would not employ such a system in the upcoming prefectural elections. ${ }^{54}$ The following day, February 19, Yuzawa reaffirmed the premier's decision. ${ }^{55}$

This campaign to prevent a candidate recommendation system's use in the approaching prefectural elections predictably had developed among elected independent candidates, mainly from the reform right. On January 27, 1943, 20 such members including Satsuma, Nakano Seigō, Mitamura Takeo (1899-1964), and Akao Bin, organized the Hisuisen yüshi daigishikai (Unrecommended Candidates Volunteer Diet Man's Association) in order to block a recommendation system's future use. ${ }^{56}$ Parliamentary opposition proved instrumental then in causing the government to abandon the candidate recommendation system. This decision came as a great shock to the Adults Association, particularly at the local level, for Adults Association prefectural leaders believed that the recommendation system, despite certain flaws, was the most powerful weapon in their arsenals to destroy still existing jiban. ${ }^{57}$

The 81st Session's major crisis erupted over the Tojo cabinet's attempt to revise the Wartime Penal Regulations Code. The crux of the bill was that those who "opposed" the national government in wartime or otherwise disturbed public tranquility might be punished by up to seven years penal servitude or imprisonment. ${ }^{58}$ Maintaining that the Penal Regulations reform provisions were unclear and that its passage into law might result in the emergence of a police state (ankoku seiji), an odd alliance ranging from reform rightists to liberal former Dōkōkai and former Socialist Masses Party members banded together to try to prevent passage.

On March 6, the Political Society's Investigatory Committee approved the government's draft proposal. That same afternoon, Tsu- 
gumo Kunitoshi led a parliamentary group whose members, aware of the growing resistance to the bill, tried to ramrod the unamended legislation through the in-house Diet committee. A brawl between the bill's supporters and its detractors erupted. Amidst overturned desks and flying inkstands, opponents literally fought with Tsugumo's flying wedge to prevent the bill from reaching the Diet floor. An emergency cabinet meeting as well as an emergency Political Society Directorate meeting convened in an attempt to pressure recalcitrant members into passing the legislation. Late night phone calls and veiled threats did not dissuade opponents, and, on the Diet floor, former Dōkōkai leader Hatoyama joined with Töhódoshikai (the public association successor to the defunct, political Tōhōkai) director Nakano to denounce the pending legislation..$^{59}$ Despite their efforts, the Penal Regulations revision passed unamended, but not, as the Tojo cabinet had hoped for the sake of homefront unity, unanimously. Contrary to the government's expectations and desires then, a complacent Diet did not perfunctorily rubber stamp legislative bills.

During the following 82nd Extraordinary Diet Session (June 16-18, 1943), Akao Bin, in the middle of Prime Minister Tojo's address to Lower House members, suddenly leaped to his feet and shouted out that Tojo act, not just talk, about contemporary problems. Compounding Akao's rudeness was the presence of foreign observers from various so-called Greater East Asia Co-Prosperity Sphere nations who received an unexpected look at Japanese parliamentary politics in action. The Lower House leadership censured Akao for his unruly conduct, but, in his support, Nakano, Hatoyama, Etō Genkurō (1879-1957), a retired major general re-elected as an independent, and Shiratori Toshiō walked out of the Political Society. ${ }^{60}$

\section{The Disintegration of Homefront Unity}

These domestic political disruptions added to the military woes besetting Japan's far-flung armies and navies and the besieged Tojo government became increasingly repressive. It is possible to date this phenomenon from August 1942 when Tojo elevated Colonel Shikata Ryojji (1896- ) to Tokyo Military Police Commander. Following the Midway (June 1942) and Guadalcanal (August 1942-January 1943) military debacles and the increased political dissent exemplified by 
Diet events, Tojo lashed out at political opponents and attempted to coerce them into supporting homefront unity. As the former Military Police commander put it, in the Pacific War's early stages Tojo used the military police sparingly but, as his policies came under fire and as his popularity began to fade, he employed the military police to try to suppress any opposition. ${ }^{61}$ One such abuse of power Tojo directed against the reform right. On October 18, 1943, thought police arrested Nakano Seigō as part of a nationwide roundup of Tōhōdōshikai and reform rightist Kinnō makoto musubisha members. Thought police alleged that these groups conspired to overthrow the Tojo cabinet and to assassinate its leaders.

The previous April, Tojo had pushed through a cabinet reorganization in hopes of solidifying contacts among the government, the IRAA, and the Political Society. He appointed Yamazaki Tatsunosuke Agriculture and Forestry Minister and Ōasa Tadao Minister of State; the IRAA's vice director and Adults Association director Andō Kisaburō became Home Minister, and Viscount Okabe Nagakage (1884-1970), an IRAA and Political Society Directorate member, assumed the Education Ministry portfolio. In spite of the obvious political intent of these appointments, when Tojo asked Ōasa to secure the Diet's cooperation in preventing the incarcerated Nakano from taking his seat in the 83rd Extraordinary Diet Session scheduled for October 26-28, 1943, Ōasa refused. To make matters worse, Ōasa informed a chagrined Tojo that Nakano, as a Diet member, could not be prevented from taking his seat. Moreover, if Nakano were not allowed to assume his Diet seat, all independence under law would vanish in Japan. ${ }^{62}$ The newly appointed Metropolitan Police Board director Susugida Yoshitomo (1897-1963), who as Kagoshima governor during the 1942 election exhibited few qualms about election interference, told Tojo that there was insufficient evidence to hold Nakano past October 25. Chief Prosecutor Matsuzaka doubted that enough evidence existed for an indictment and ultimately, even though Colonel Shikata took personal charge of Nakano's interrogation, the police freed Nakano on October 25. During the early morning hours of the next day, Nakano committed suicide. The episode again illustrates that the Diet was not a rubber stamp but a still respected institution and that the rule of law still was to a marked extent respected in wartime Japan. 
The preceding examples of Diet dissent and of Diet defiance of the Tojo cabinet's wishes clearly make it impossible to support the assertion that the 1942 General Election served to provide a "dictatorial political base" for Tojo's government or that the Diet found itself completely unified under the Political Society. It is true that the existing 1942 political parties did dissolve in order for their members to enter the Political Society, but a one-nation one-party system did not result. ${ }^{63}$ Neither did the civilian right restrict its criticism of Tojo's regime to the final stages of the war because the reform right continually criticized the Tojo cabinet from the opening days of the Pacific War. ${ }^{64}$ Even anti-Diet contemporaries recognized the lack of national unity and Diet solidarity. Military Affairs Bureau chieftain Satō Kenryō, for instance, commented that while outwardly the Diet appeared united and strong, internally the factionalism characteristic of the former political party era still was rampant. ${ }^{65}$ Finally, the Political Society, in spite of its obstensible monopoly on political power in Japan, never became the mass mobilization political party that its progenitors envisaged. In that sense, it cannot be equated with prototypical totalitarian style parties that "exist to organize a monopoly of political power" and "are permanent ruling parties." ${ }^{\text {"6 }}$ Instead, the Political Society, paradoxically in a manner more representative of democratic parties, competed with the Adults Association, with the IRAA, and with the cabinet for its share of political power. Its failure to establish viable local branches, however, precluded the Political Society from activating popular support for anything. The Adults Association superseded the IRAA in assuming that role at the local level. Friction and competition, not harmony and cooperation, became the hallmarks of relations between the Society and the Adults Association.

This all suggests that wartime Japan was a pluralistic political system. ${ }^{67}$ Restrictions obviously existed on individual and on political liberties. Simultaneously, though, competition for political power shares continued and the former party politicians enjoyed a resurgence to national prominence as cabinet ministers. The resilience and tenacity of the "defunct" political parties' leading personalities, who, after all, dominated the 1942 General Election and subsequently recovered gradually their positions of prestige and authority within 
the wartime cabinets, indicates that although the political parties were institutionally weak, the party politicians and their associated local power bases were individually strong. If, as suggested, the party leadership dissolved their parties to advance their own interests, their decision appears sound in the light of their return to political power in 1942 and in 1943. The former party men took care of their own interests. That may seem like a callous disregard of constituents' interests, but the prewar Japanese politician never considered himself to be the representative of a mass constituency. Rather he represented special, local interests, personified by the community leaders. The politician was as much a creature of his jiban as his jiban was the creation of his labors.

Indeed the former party politicians outlasted Tojo's government, the Political Society, the IRAA, and even their archenemy the Adults Association. After Tojo's resignation as prime minister on July 18, 1944, Shimada Toshio, Maeda Yonezō, and Machida Chūji appeared as cabinet ministers in Prime Minister Koiso Kuniaki's new government. The government dissolved the Political Society itself on March 30, 1945 to be replaced by yet another vain attempt at creating a monolithic political party, the Dai Nippon seijikai (Greater Japan Political Association). A May 8, 1945 cabinet decision disbanded the IRAA and the Adults Association so that their respective members might enter still another newly created homefront unity vehicle, the Kokumin giyūtai (People's Heroic Fighting Corps) ${ }^{68}$

Throughout the Pacific War, the former party leaders and their top lieutenants continued to vie successfully for a share of political power as illustrated by their again attaining cabinet level rank. This was possible because even in a conservative but pluralistic society the government needed the politicians' expertise and specialized knowledge to conduct state affairs. The Meiji Constitution, even with the conservative interpretation then attached to that document, made it impossible for any government to ignore the Diet. ${ }^{69}$ Cabinets, then, had to cooperate with the former party leaders to have their legislation approved in the Diet. This arrangement was not as onesided as it might appear since it provided the former party leaders sufficient leverage to dominate the 1942 General Election's candidate recommendation system, the Political Society, and despite friction among 
membership, to be able to steer government introduced legislation through the Lower House passage. In exchange for the political continuity that they provided in the Diet and in the Political Society, whose structure ultimately followed the basic Yokudo formulation, former party leaders were rewarded with cabinet level rank. The give and take of the parliamentary system, including the electoral process, functioned in Japan throughout the Pacific War. ${ }^{70}$

These developments, in turn, highlight the Japanese political experience since the 1868 Meiji Restoration characterized by a continual dualism between reform and conservative thought, or succinctly, the struggle of change versus tradition. In value laden terms, the process has been described as the conflict between absolutism and liberalism. The patterns of the general elections of 1892, 1915, 1928, and 1942 serve as excellent examples of this clash between traditional and reform currents. It is not surprising then that there are marked similarities among all four elections, even to the point of similar rhetoric to rationalize illegal interference.

In such a political atmosphere, the 1942 General Election was not a Hobson's choice. Viable independent candidates contested, in many cases successfully, the election with their recommended counterparts. Moreover, the pageantry associated with "totalitarian style" elections was conspicuously lacking. The chief reason for the 1942 election campaign's dullness perhaps was the lack of lower level political mobilization units, similar to the Nazi block leader or the Soviet agitator, to activate the population to participate "properly" in the campaign. ${ }^{71}$ It is true that the Home Ministry and the cabinet mobilized the neighborhood association network for the election, but the Police Security Law of 1900 by strictly defining the separation of public and political associations restricted neighborhood association functions during the campaign. It remained a semi-free institution reflecting the wartime society.

Despite the preponderant military influence, the army was not a paramount influence in the campaign. The Military Affairs Bureau failed in all its one-nation one-party schemes for the IRAA; its leaders Mutō and Satō discovered themselves outclassed by Home Ministry bureaucrats during the pre-election campaign planning, and Military Affairs 
Bureau designs for the Adults Association also ended in disillusionment. ${ }^{72}$ During the candidate selection process, regimental area commanders did not have the final voice in picking recommended candidates, and the military police did not interfere in the election campaign itself. ${ }^{73}$ All documentary evidence indicates that election supervision and election regulation remained where it traditionally had been, within the Home Ministry.

Home Ministry police did attempt to regulate strictly the election campaign. Part of this rigid enforcement may be attributed to the wartime conditions that added further to the already existing restrictions on individual liberties that, the other part of the eyuation, an increasingly conservative government had erected to protect itself from the perceived menace of social change. When police took the lead in directing election interference, they did so in traditional forms. While it cannot be denied that the police did obstruct some candidates' campaigns, their interference was irregular in application and depended on the prefectural governor's predilections. While the wartime Japanese political milieu may not have been the most appealing, it simply contained too many "peculiarities," an effective, functioning constitution, a working legislature, free elections, a functioning judiciary that insured an appeal to law as ultimately embodied in the constitution, to be labeled as "fascist." "

The pluralistic pre-war Japanese society did not coalesce into a "monolithic state" nor was it a "totally integrated" one during the Pacific War. Sectional, political, ideological, and economic interests continued to exist, never in complete harmony with an idealized "homefront unity," but rather as they had developed since the Meiji Restoration, co-existing, each supreme in its own sphere and each jealously guarding its own perogatives. Even the optimum conditions produced by a spectacular series of battlefield victories, capped by the capture of Singapore, could not fully reconcile these pre-war Japanese society trademarks. Neither "absolutism" nor "liberalism" ever completely eclipsed the other. A mixture of these two strains of thought emerged in the conservative, pluralistic, pre-war Japanese society and during the Pacific War culminated in the form of a semi-free state. 


\section{Abbreviations}

Archive Microfilm Reproductions of Selected Archives of the Japanese Army, Navy, and Other Government Agencies, 1868-1945.

GDSSR Gendaishi shiryō

HS Hochi shimbun

JR Microfilm Japanese Rarities

KKS Kokuritsu kobun shokan

KS Kokumin shimbun

MS Miyako shimbun

NCS Naigai chōsa shiryō

NMSS Naimushō shi

OAS Osaka Asahi shimbun

Senzen Senzen ni okeru uyoku dantai no jōkyō shiryō

SG Shisō geppō

SUNJ Showa 17 nen ni okeru shakai undō no jōkyō

TAS Tokyo Asahi shimbun

TG Tokkō geppō

TNNS Tokyo Nichi Nichi shimbun

TS Taiheiyō sensō

YKUS Yokusan kokumin undōshi

YS Yomiuri shimbun 


\section{Notes}

\section{Preface}

1. Ozaki Yukio, "Tojo shushō ni ataeraru kōkaijō" (An Open Letter to Prime Minister Tojo), April 1942 in Kakegawa Tomiko, ed., Gendaishi Shiryō (Documents of Contemporary History) hereafter GDSSR, 42, Shisō tōsei (Thought Control) (Tokyo: Misuzu shobō, 1976), 1090.

\section{Chapter One}

1. For further information on these community leaders see, Masumi Junnosuke, "Josetsu" (Preface), in Nihon seiji gakkai, eds., Nenpō seijigaku 1972: "Konoe shintaisei" no kenkyū (The Annals of the Japanese Political Science Association 1972: Studies on Konoe's New Order) (Tokyo: Iwanami shoten, 1973), 1-19 and Gordon Berger, Parties Out of Power in Japan 1931-1941 (Princeton: Princeton University Press, 1977), 18-30. Berger defines this class as "local elites."

2. R. L. Sims, "National Elections and Electioneering in Akita ken, 19301942," in W. G. Beasley, ed., Modern Japan (Tokyo: Charles E. Tuttle, 1976), 94-9.8. For Japanese po'ice records of all 1942 general election Tokyo candidates see, Library of Congress, comp., Microfilm Reproductions of Selected Archives of the Japanese Army, Navy, and Other Government Agencies, 1868-1945 (Hereafter cited as Archive) Title 1467 Naimushō jōhōka (Chief, Intelligence Section Home Ministry), Dai 21 kai shügiin gïn sōsenkyo ni okeru kakusho betsu (Tokyo) undō jōsei shiryō April 24, 1942 (Data Assembled by Each Police Precinct on Campaigning in Tokyo during the 21 st General Election to the House of Representatives) Reel 212, Frame 80890-Reel 213, Frame 81740. Examination of these documents gives an idea of the immense complexity and intricate relationships jiban involved.

3. Mikawashima keisatsuchō (Mikawashima Police Chief), "Mikawajō 1153 gō," (Mikawashima Police Chief Intelligence Report 1153) Secret April 23, 1942 and Motofuji keisatsuchō (Motofuji Police Chief), "Motojōhi dai 2036 gō," (Motofuji Police Chief Secret Intelligence Report Number 2036) Secret April 22, 1942 in Archive Title 1469 Naimushō jōhōka, Shōwa 17-nen 4-gatsu shikōo shügiin giin sōsenkyo jōsei toji: February 9, 1942-May 1, 1942 (Papers Relating to General Elections to the House of Representatives Held in April 1942) Reel 214, Frames 83196 and 83154 respectively.

4. Furui Yoshimi shi danwa sokkiroku (A Stenographic Record of the Conversation with Mr. Furui Yoshimi) (Naiseishi kenkyūkai shiryō unnumbered, n.d.), 11. The nadir of such practices was struck when the Seiyükai, preparing for the first universal male suffrage election in 1928, transferred 37 governors and 44 police directors. Taikakai, eds., Naimusho shi (The History of the Home Ministry) (Tokyo: Chihō zaimu kyōkai, 1970-1971), 2, 352. Hereafter cited as NMSS. Also author's interview with the Honorable Furui Yoshimi, M. P.

5. The Saitō Makoto cabinet in late 1932 established a commission with review power over retirement of government officials and the next year an Imperial Ordinance guaranteed the status of police officials. Berger, Parties, 
64. However, according to my interview with Furui Yoshimi, a veteran Home Ministry official, the regulations did not meet expectations.

6. Toyama Shigeki et al., eds., Showa shi; 2nd ed., rev. (A History of the Showa Reign) (Tokyo: Iwanami shinsho, 1971), 104. NMSS, 2, 509-511. Ishii Kin'ichirō, "Nihon fuashizumu to chihō seidō" (Japanese Fascism and the Regional System), Rekishigaku kenkyū, 307 (December 1965), 2.

7. Fujiwara Akira, Nihon minsh ū no rekishi, 9 Sensō to minshū (A History of the Japanese Masses, 9 War and the Masses) (Tokyo: Sanseido, 1975), 138141. Akimoto Ritsuo, Sensō to minshū (War and the Masses) (Tokyo: Gakuin shobō, 1974), 14-19. Author's interview with Hazama Shigeru, Tokyo, March $11,1977$.

8. Peter Duus, "Nagai Ryūtarō: The Tactical Dilemmas of Reform," in Albert M. Craig \& Donald H. Shively, eds., Personality in Japanese History (Berkeley: University of California Press, 1970), 400-401, 416.

9. Gordon Berger, "The Search for a New Political Order: Konoe Fumimaro, the Political Parties, and Japanese Politics during the Early Shōwa Era," Diss.: Yale University, 1972, 400.

10. George O. Totten III, The Social Democratic Movement in Prewar Japan (New Haven: Yale University Press, 1966), 102-103 and Maruyama Masao, Thought and Behavior in Modern Japanese Politics (London: Oxford University Press, 1963), 325.

11. Tetsuo Najita, "Nakano Seigō and the Spirit of the Meiji Restoration in Twentieth Century Japan," in James W. Morley, ed., Dilemmas of Growth in Prewar Japan (Princeton: Princeton University Press, 1971), 401, 404.

12. Itō Takashi, Nihon no rekishi, 30 Jügonen senso (The History of Japan, 30 The Fifteen Years War) (Tokyo: Shogakkan, 1976), 248; Hayashi Shigeru, Nihon no rekishi, 25 Taiheiyo sensō (The History of Japan, 25 The Pacific War) (Tokyo: Chūō kōron sha, 1967), 149.

13. E. H. Norman, "Politics," n.d., n.p., but written after April 1942, 8. I am indebted to Mr. Ōkubo Genji for providing me with a copy of this draft article. For a detailed treatment of the IRAA's formation consult Berger, Parties, especially Chapter Six. Details of each session are available in Yokusan kokumin undōshi kankōkai, eds., Yokusan kokumin undōshi (A History of the Yokusan Peoples' Movement) (Tokyo: Yokusan kokumin undōshi kankōkai, 1954), 97-132. Hereafter cited as YKUS.

14. For a sampling of these proposals see YKUS, 45, 64, and 94. A more detailed account is offered in Imai Seiichi and Itō Takashi, eds., GDSSR, 44 Kokka sōdōin, 2 (National Mobilization) (Tokyo: Misuzu shobō, 1974), 161, 173 , and 186-233.

15. Bōeichō bōei kenshūsho senshi shitsu, eds. (Self Defense Headquarters Self-Defense Training Institute War History Room), Daihon'ei rikugun bu: Daitōa sensō kaisen keii, 1 (Imperial Headquarters Army Branch: The Particulars of the Outbreak of the Greater East Asia War, 1) (Tokyo: Asagumo shimbun sha, 1973), 278.

16. Robert M. Spaulding, Jr., "The Bureaucracy as a Political Force, 19201945," in Morley, ed., Dilemmas, 62 and by the same author "Japan's 'New Bureaucrats', 1932-1945," in George M. Wilson, ed., Crisis Politics in Prewar Japan (Tokyo: Sophia University Press, 1970), 51-70. Also Kaisen keii, 1, 297 and 408 .

17. GDSSR, 44, lxxxiv-lxxxvii. Akagi Shuruki, "Kokumin saisoshiki" (The Reorganization of the Nation), Nenpō: 1972, 50-51. Bōeichō bōei kenshūsho 
senshi shitsu, eds., Daihon'ei rikugun bu: Daitōa sensō kaisen keii, 2 (Tokyo: Asagumo shimbun sha, 1973), 422. Maki Tatsuo, "Watakushi to shintaisei-gun no kitai to genmetsu" (The New Order and I: The Military's Expectations and Disillusionment), Rekishi to jinbutsu, 32 (April 1974), 46.

18. GDSSR, 44, lxxxvii.

19. Akagi, op. cit., 50 .

20. See YKUS, $95-97$ for the complete Home Ministry plan.

21. GDSSR, 44, lxxix.

22. YKUS, 164-165. Also see Iriye Tanenori, "Konpon rinen o ikketsu seyo" (Settle Fundamental Ideas), Kaizō, 23:3 (February 1941), 103-104. The cooperative councils were to serve as conduits carrying instructions from a central executive committee down to the local level and transmitting problems and aspirations from that level back up to the central executive. At the lowest administrative levels, the cooperative councils' function would be exercised in the community councils. The primary purpose was to replace the existing prefectural legislatures, which were dominated by the Home Ministry, with the councils as forms of popular expression. See Berger, Parties, 305-306.

23. Cited in Hayashi, 167.

24. Yabe Teiji, Konoe Fumimaro (Tokyo: Kobundo, 1952), 2, 198. Hereafter cited as $K F, 2$.

25. Kyoto daigaku bungakubu kokushi kenkyūshitsu, eds. (Kyoto University Department of Literature National History Research Room), Nihon kindaishi jiten (Dictionary of Modern Japanese History) (Tokyo: Tōyō keizai shinpō sha, 1958), 106. Those arrested were imprisoned between three and four years but, immediately after the Japanese surrender, on September 29, 1945, a not-guilty verdict was returned. A recent assessment by one of the victims, Katsumata Seiichi (1908- ), today a Socialist M. P., is that Hiranuma trumped up the incident to discredit Konoe's new order. See, Katsumata Seiichi, "Kikakuin jiken o megutte" (About the Planning Board Incident), in Itō Takashi, ed. Kataritsugu Shöwa shi, 3 (Tokyo: Asahi shimbunsha, 1976), 204-208.

26. Yokogoshi Eiichi, "Mutō jidai no seiji-ryoku gaku(1)" (A Study of Political Dynamics in the Non-Political Party Era), Nagoya daigaku hōsei ron$s h \bar{u}, 32$ (September 1965), 19. I am again deeply indebted to Mr. Okubo Genji for obtaining a copy of this article for me.

27. Ibid., 20.

28. Hasegawa Masayasu, Showwa kenpō shi (A History of the Showa Constitution) (Tokyo: Iwanami shoten, 1962), 150-151. Also refer to YKUS, 176177.

29. Yokogoshi, 23.

30. Ibid., 28 .

31. YKUS, 175 and Yokogoshi, 32.

32. "Chian keisatsu hō," in Watanabe Tsutsui, et al., eds., Nihon kenpōshi (Japanese Constitutional History) (Tokyo: Tokyo daigaku shuppan kai, 1976), 137-140. On the implications of the legislation see, Kisaka Jun'ichirō, "Taisei yokusankai no seiritsu" (The Formation of the IRAA), in Iwanami henshū bu, eds., Iwanami kōza Nihon no rekishi, 20 Kindai 7 (Iwanami's Lectures on Japanese History, 20, Modern 7) (Tokyo: Iwanami shoten, 1976), 292.

33. Fujita Yoshimitsu, Yokusan senkyo tokuhon (The Yokusan Election Reader) (Tokyo: Shin kigensha, 1942), 23, 28-33: NMSS, 2,341 and 699: Furui danwa, 28-33: Soma Masao, Nihon senkyo keihatsu shi (A History of 
the Development of Japanese Elections) (Tokyo: Akaruku tadashii senkyo suishin zenkoku kyōgikai, 1972), 167-169.

34. For some plans see Shōwa kenkyūkai jimūkyoku, eds., Seiji kik̄ō kaishin taikō (An Outline for Reform of the Political Structure) (Tokyo: Shōwa kenkyūkai, 1940). I am again indebted to Mr. Ōkubo Genji for providing me with a copy of this document. Also see Ōnishi Kunitoshi, "Yokusan gikai no senkyo seidō ron" (A Theory for the Yokusan Diet's Election System), Rekishi Hyōron, 16:1 (January 1941).

35. Harada Kumao, Saionji-kō to seikyoku, 8 (Prince Saionji and the Political Situation) (Tokyo: Iwanami shoten, 1967 ed.), 231.

36. Akagi, op. cit., 68.

37. Fujita, 44.

38. YKUS, 151-152. Eliminating self-endorsements was designed to stop the abuse of running for public office just to advertise one's person or business.

39. Ibid., 295-299.

40. Gotō Ryünosuke-shi danwa dai-5-kai sokkiroku (Stenographic Record of the Conversation with Mr. Gotō Ryūnosuke) (Naiseishi kenkyū shiryō dai70) (Tokyo: Naiseishi kenkyūkai, 1968), 21.

41. Hazama Shigeru-shi danwa dai-3-kai sokkiroku (Stenographic Record of the Conversation with Mr. Hazama Shigeru) (Naiseishi kenkyū shiryō dai33) (Tokyo: Naiseishi kenkyūkai, 1966), 140-143. Author's interview with Hazama Shigeru; Fujita, 47 and Akagi, 58. A draft of the complete plan may be found in Naikaku kanbō shūji (Cabinet Secretariat), "Shūgiin giin senkyohōchu kaisei hōritsuan" (A Draft for Legal Reform of the Election Law for the House of Representatives), Secret, January 19, 1941 in Library of Congress, comp., Microfilm Orien Japan Title 37 Keishichō (Metropolitan Police Board), Documents on Japanese Police Activities Tokyo, 1933-1945 Reel 37:3, Frame $373165-373196$.

42. Isojirō Furusawa, "The Wartime Non-Party Diet," Contemporary Japan, 10:4 (April 1941), 462-464.

43. Hayashi, 302. Also see Rekishigaku kenkyūkai, eds., Taiheiyō sensō, 4 Taiheiyo sensō, 1 (The Pacific War, 4 The Pacific War, 1) (Tokyo: Aoki shoten, 1972), 202. Hereafter cited as TS, 4. Ishida Takeshi, Nihon kindaishi taikei, 8 Hakyoku to heiwa (Systematized Modern Japanese History, 8 Catastrophe and Peace) (Tokyo: Tokyo daigaku shuppankai, 1968), 29.

44. Yokogoshi, 34.

45. Keihōkyoku hōanka (Police Bureau Peace Preservation Section), "Saikin ni okeru seiji jōsei" (Recent Political Conditions), Top Secret, June 2, 1942 in Library of Congress, comp., Microfilm Japanese Rarities Title 3:16 Keihōkyoku hōanka, Seiji kankei shorui tsuzuri 1941-1942 (Papers Related to Politics, 19411942) Reel 44, Frame 0106. Hereafter cited as $J R$ 44. I am most grateful to Professor Hora Tomio of Waseda University who very kindly granted me access to this document collection and also provided me with an index to the documents. My thanks are also given to Mrs. Inohara Shoko of the Waseda Library Microfilm Room for her gracious assistance.

46. Ibid., and Yokogoshi, 40.

47. This and subsequent police assessments of the new negotiating groups are based on $J R$ 44, Frame 0106.

48. Yokogoshi, 46-47.

49. Asahi shimbunsha, ed., Shöwa jühachi-nen Asahi nenkan (Asahi Yearbook 1943 Edition) (Tokyo: Asahi shimbunsha, 1943), 106. 
50. Keishichō jōhōka, "Keishichō jōhōka jimu seiseki-kara Shōwa 16-nen 10-gatsu hatsuka itaru Shōwa 17-nen 6-gatsu 15-nichi” (Reports on Work by the Intelligence Section, Tokyo Metropolitan Police Board from October 20, 1941 to June 15, 1942), Secret in Archive Title 1527 Keishichō jōhōka jimu seiseki Showa 12-nen 12-gatsu 24-ka itaru Showa 20-nen 4-gatsu kokonoka (Reports of Work by the Intelligence Section, Tokyo Metropolitan Police Board: December 24, 1937-April 9, 1945), Reel 225, Frame 97187. A review of Dai 77-78 kai teikoku gikai shügiin giin iinkaigiroku-Shōwa 16-nen 11-gatsu 17nichi (Minutes of the 77-78 Imperial Diet House of Representatives Committee Sessions for November 17, 1941), 6 reveals Miyazawa's remarks were stricken from the official record.

\section{Chapter Two} 200.

1. John Morris, Traveller From Tokyo (New York: Sheridan House, 1944),

2. Nagai Kafū, Nagai Kafū zenshū, 23 (Collected Works of Nagai Kafū) (Tokyo: Iwanami shobo, 1963), 250.

3. Satō Kenryō, Daitōa sensō kaikoroku (Memoirs of the Greater East Asia War) (Tokyo: Tokuma shoten, 1966), 178.

4. In these debates, Tojo acknowledged that unavoidably election rallies would fall under the new laws, but that the government's intention was to control groups that might adversely affect war aims. He stated that he did not think political parties would be adversely affected. Dai 78-kai teikoku gikai shügiin giin iinkaigiroku, dai 6 rui dai 2 gō Genron, shuppan, shükai, kessha ra rinji torishimari hōan iinkaigiroku dai 1 kai Showwa 16-nen 12-gatsu 16-nichi (Minutes of the 78th Imperial Diet House of Representatives Committees, Sixth Series Second Number Proceedings of the Special Measures for Control of Speech, Publication, Assembly, and Association Committee First Session Minutes for December 16, 1941), 2-11.

5. Ibid., and Ishida, 18-19.

6. Chōsa shiryō kyōkai, ed., "Dai 21 kai sōsenkyo narabi ni kore o meguru saikin no seiji jōsei ni kansuru shiryō" (Documents Related to the 21 st General Election to the Lower House as well as Surrounding the Recent Political Situation), Naigai chōsa shiryō, 14:6 (August 1942), 2. Hereafter cited as NCS.

7. Keishichō, "Shūgiin giin chōsa hyō" (A List of Investigations of Lower House Representatives), Top Secret February 1942 in Archive Title 1468 Naimushō jōhōka, Shūgiin giin sōsenkyo (junbi kikan) shorui toji (Papers Relating to Preparations for the General Election to the House of Representatives) Reel 213, Frame 91797-91812.

8. On this point see Berger, Parties, 43.

9. "Shūgiin giin sōsenkyo taisaku-Naimu daijin kakugi teian setsumei yōshi" (The Essentials of the Home Minister's Explanation of the Cabinet Proposal Concerning Measures for the General Election to the Lower House), February 16, 1942 in Kokuritsu kōbun shokan (Japan National Archives, hereafter cited as KKS), Kōbun ruishū dai 66-hen (Shöwa 17-nen) kan ichi, File 2A 12 rui 2547 (Cabinet Documents Series 66 (1942) 1), Document \# 27.

10. "Konji shūgiin giin sōsenkyo ni nozomu seifu no jōtai ni tsuite no naikaku sōridaijin setsumei" (The Cabinet Prime Minister's Explanation about the Government Position Faced with this General Election for the Lower House), Top Secret (February 18, 1942), in KKS, File 2A 12 rui 2547 Document \#28. 
11. Kuroda Iwao, "Yokusan senkyo to kokumin rinri" (The Yokusan Election and National Ethics), Chüō kōron, 57:4 (April 1942), 9.

12. Taisei yokusankai sōmukyoku shomubu (IRAA General Affairs Bureau Miscellaneous Affairs Department), "Shōwa 16-nen 11-gatsu 14-ka no shitsumon (Taisei yokusan undō to senkyo ni kansuru mondai-kabu sōshiki ni kansuru mondai) no tōben," Secret November 15, 1941 (Answers to Questions of November 14, 1941, [Concerning the Election and the Imperial Rule Assistance Movement and Stock Organization]) in KKS Taisei yokusankai kankei shorui tsuzuri, File 2A 40 shi 13 (Papers Relating to the IRAA) Document \# 58. Although not used during the 77th Session, the document was employed during the 79th Session. See Dai 79-kai teikoku gikai shügiin giin iinkaigiroku, dai 1 rui dai 1 gō yosan ïnkaigiroku dai 8 kai-Showa 17-nen 1-gatsu 29-nichi (Minutes of the 79th Imperial Diet House of Representatives Committees, First Series First Number Budget Committee 8th Session for January 29, 1942), 187 and 193.

13. Tokyo Asahi shimbum (Asahi newspaper), October 21, 1941, evening ed., 1; January 10, 1942, 2 and January 14, 1942, 1. Hereafter cited as TAS and, unless otherwise noted, all newspapers are morning editions. Also consult Furui danwa, 42.

14. Mutō Akira, Hitō kara sugamo e (From the Philippines to Sugamo) (Tokyo: Jitsugyo no Nihonsha, 1952), 71-72 and Mutō Akira, "Nikki" (Diary), n.p. n. pag. in Boeichō senshi shitsu (Self Defense Headquarters War History Room). Satō Kenryō, Satō Kenryō no shogen (Satō Kenryō's Testimony) ('Tokyo: Fūyō shobō, 1976), 371 and Satō, Kaikoroku, 286.

15. Hashimoto Seinosuke-shi danwa sokkiroku (Stenographic Record of the conversation with Mr. Hashimoto Seinosuke) (Naiseishi kenkyū shiryō dai-73) (Tokyo: Naiseishi kenkyūkai, 1964), 18.

16. Hayashi, 302; Mutō, Hitō, 72; Satō, Shogen, 370. Satō flatly admits that he and Mutō were amateurs with no feel for elections and were overmatched by the Home Ministry members.

17. Kanpō gōgai-Shōwa 17-nen 1-gatsu 22-nichi, Dai 77-79-kai teikoku gikai shügiin giji sokkiroku dai 3 gō (Official Gazette Edition-Stenographic Record of the Proceedings of the 77-79th Plenary Sessions of the Imperial Diet House of Representatives January 22, 1941), 25.

18. Dai 79-kai teikoku gikai shūgïn giin ïnkaigiroku, dai 1 rui dai 1 go yosan iinkaigiroku dai 7 kai-Shōwa 17-nen 1-gatsu 28-nichi (Minutes Budget Committee 7th Session Minutes for January 28, 1942), 164 and Yosan iinkaigiroku dai 8 kai, op. cit., 200-201.

19. Dai 79-kai teikoku gikai shügïn giin ïnkaigiroku, dai 1 rui dai 3 gō yosan iinkaigiroku dai 2 bunka kaigiroku dai 1-Showa 17-nen 1-gatsu 31-nichi (Minutes of the Budget Committee's Second Subcommittee First Session January 31,1942 ), 19-20.

20. The Japan Times \& Advertiser, February 18, 1942, 1-3.

21. Cited in YKUS, 435.

22. See Appendix A for a comp'ete translation.

23. Cf., Robert Scalapino, "Elections and Political Modernization in Prewar Japan," in Robert E. Ward, ed., Political Development in Modern Japan (Princeton: Princeton University Press, 1968), 251 discussion of "guided democracy."

24. These assessments are found in investigations of Dietmen cited in Note 7 above.

25. Yokusan seiji taisei kyōgikai, ed., Yokusan seiji taisei kyōgikai kiroku 
(The Record of the Imperial Rule Assistance Political Organization Council) Secret (Tokyo: 1942), 9-11. I am indebted to Mr. Hashimoto Seinosuke for being considerate enough to lend me his copy of this valuable and rare document. Hereafter cited as Kiroku.

26. Ibid., 11.

27. These charters may be found in Yokusan seiji taisei kyōgikai, ed., Yokusan seiji taisei kyogikai no shimei ('The Mission of the IRAPOC) (Tokyo: Yokusan seiji taisei kyōgikai, 1942), 16-17. I am again grateful to Mr. Hashimoto for lending me his copy of this pamph'et.

28. Author's interview with Mr. Hashimoto Seinosuke, Tokyo, September $21,1976$.

29. See the untitled, hand-written draft of this instruction in Archive Title 1468 Reel 213, Frame 82243. The document also notes that the War Ministry already had notified all regimental area commanders of this policy.

30. Based on branch membership composition analysis in NCS, 39-58.

31. Hashimoto Seinosuke, "Rengōkoku saikō shireikan Dogurasu Makkāsā kaka" (Letter to Supreme Allied Commander Douglas MacArthur), July 30, 1949, n.p., 12 gives these figures and one of 400,000 plus yen for headquarters expenses. I am indebted to Professor Itō Takashi for providing me a copy of this letter.

32. Kiroku, 34.

33. "Jōkyoku memō-Yokudō no shinseiji kessha soshiki an" (Situation Memo: The Yokudō's Draft Organization for a New Po'itical Association), in Kokusaku kenkyükai shühō, 1 (Part 1) 9 (March 1, 1942), 6.

34. TAS, February 11, 1942, 2.

35. Yokogoshi Eiichi, "Mutō jidai seiji-ryoku gaku (2)," Nagoya daigaku hōsei ronshū, 33 (December 1965), 42. I am again grateful to Mr. Ōkubo Genji for obtaining a copy of this article for me.

36. Aritake Shuji, Maeda Yonezō den (Maeda Yonezō's Biography) (Tokyo: Maeda Yonezō denki kankōkai, 1960), 408-409.

37. NCS, 28-29.

38. Ibid., 30.

39. Naimushō keihōkyoku hōanka, ed., Tokkō geppō (Thought Police Monthly) (March 1941), 42. Hereafter cited as TG.

40. $T G$ (February 1942), 65-66.

41. TG (April 1942), 54.

42. Chihōkyoku-keihōkyokuchō, "Daitōa sensō kansui senkyo kantetsu undō jisshi yōryō," in Osaka Asahi shimbun, February 24, 1942, 2. Hereafter cited as $O A S$.

43. On "proving" election success see Scalapino, 250.

44. "Daitōa sensō kansui yokusan senkyo kantetsu undō senden yōryō" (Outline for Publicizing the Campaign to Execute a Yokusan Election for the Successful Prosecution of the Greater East Asia War), in Shimin, 37:3 (March 1942), 61-64.

45. "Daitōa sensō kansui yokusan senkyo kantetsu undō chūō jisshi jikō" (Matters for Central Execution in the Campaign to Accomplish a Yokusan Election for the Successful Prosecution of the Greater East Asia War), in Shimin (March 1942), 65-67.

46. Cf., "Sangatsu no jōkai tettei jikō an (Kakugi kettei)" (Cabinet Decision on the Draft for Discussion Matters at the March General Meetings), February 4, 1942 in Archive Title 1463 Naimushō chihōkyoku shinkōka (Home 
Ministry Regional Affairs Bureau Promotion Section), Burakukai, chōnaikai nado seibi no kansuru shorui, 1940-1942 (Documents Relating to Village and Town Councils, 1940-1942) Reel 211, Frame $79391-79417$ with Naikaku jōhōkyoku, ed. (Cabinet Information Bureau), Shīhō, 282 (March 4, 1942), 4-5.

47. Chihōkyokuchō, "Chihakkō dai 12 gō" (Regional Affairs Bureau Instruction Number 12), March 25, 1942 in Archive Title 1470 Naimushō jōhōka, Shōwa 17-nen 4 gatsu 30 nichi shikō dai 21 kai shügiin giin sōsenkyo kankei Naimushō tsücho toji, January-June 1942 (Home Ministry Announcements of the 21st General Election to the House of Representatives Held April 30, 1942) Reel 214, Frame 83778. Emphasis in original.

48. Keihōkyoku, ed., Senkyo ni saishi keisatsu toshite jökai shikaisha no kakui e onegai (At the Time of the Election, Requests by Police Officers to the General Meetings Messrs. Chairmen) March 1942 in Archive Title 1470 Reel 214, Frame 83651-83653.

49. Iwabuchi Tatsuo, "Seijiteki shinnin ron" (A Theory of Politically New Men), Kaizō, 24:5 (May 1942), 164.

50. Keihōkyoku, ed., Ippannin (Iwayuru dai san sha) no senkyo undō kokoroe (Information for the General Public [So-Called Third Persons] About the Election Campaign) cited in full in Fujita, 202-219. This pamphlet originated in a joint meeting of Home and Justice Ministry plus Election Purification League members' conference in February 1942. See Keishichō kanbō shuji (Metropolitan Police Board Secretariat), "Kanjōhō dai 258 gō" (Secretariat Intelligence Report Number 258), Secret, March 3, 1942 in Archive Title 1468 Reel 213, Frame 82223.

51. Taisei yokusankai jimusōchō (IRAA Secretary General Business Affairs Director), "Sōchi dai 51 gō" (Organization Bureau Regional Directive Number 51), February 17, 1942. This document is located at the Gaimushō shiryōkan (Japan Ministry of Foreign Affairs Archive) File \#A 500.4 Taisei yokusan undō kankei ikken (dai 3 kan) (Items Related to the Imperial Rule Assistance Movement: Third Volume), 1.

52. Taisei yokusankai, ed., Rinji chūō kyōryoku kaigi kaigiroku (The Minutes of the Extraordinary Central Cooperative Committee Conference) Secret, February 25-26, 1942 (Tokyo: Taisei yokusankai, 1942), 262. I am indebted to Professor Awaya Kentarō for providing me a copy of this document.

53. Ibid., 40, 51, 59, and 78 .

54. Ibid., 46, 51, 53, 67, 74, 161, 168, 180, 277, 339, 347, and 357.

55. YKUS, 901. On Adults Association organization see Dai Nippon yokusan sōnendan honbu, ed. (Greater Japan Yokusan Young Adults Association Headquarters), Dai Nippon yokusan sōnendan no soshiki oyobi katsudō (The Organization and Activities of the Greater Japan Yokusan Young Adults Association) (Tokyo: Dai Nippon yokusan sōnendan honbu, 1942), 20-32. I am grateful to Mrs. Inohara Shoko for obtaining a copy of this document for me.

56. See Tsukui Tatsuo, ed., Nihon seiji nenpō; Shöwa jüshichinen (1) (Japan Political Yearbook; 1942 [1]) (Tokyo: Shōwa shobo, 1942), 195-201 and Endō Tetsuo ikōshū kankōkai, ed., End̄o Tetsuo ikōshū: Nihon fuashizumu to Yokusan sōnendan undō no tenkai (Endo Tetsuo's Posthumous Manuscript: Japanese Fascism and the Deve'opment of the Yokusan Young Adults Association Movement) (Tokyo: Endō Tetsuo ikōshū kankōkai, 1976? ), 5-21. I am again grateful to Mrs. Inohara Shoko for supplying me with this material.

57. Maki, 47; NMSS, 1, 492; Kaisen keii, 2, 477; Berger, Parties, 347.

58. YKUS, 902 and Tsukui, 198. The case in point being Nagano Prefec- 
ture where $80 \%$ of Adults Association members were also Reservist Association members.

59. YKUS, 907.

60. Author's interview with Hazama Shigeru who in 1942 was a vicedirector of the Adults Association national headquarters.

61. Mori Takemarō, "Senjika nōson no kōzō henka" (Changes in Farming Villages Structure During the War), in Iwanami, Nihon no rekishi, 20, 352-354. Mori's analysis is based on the study of two villages, one in Gunma and the other in Yamagata. For a different perspective on Adults Association membership see Endō, 10, 20.

62. Amaya Kikuo, "Yokusan sōnendan ni kansuru konpon mondai" (Fundamental Problems About the Adults Association), Nippon Hyöron, 17:3 (March 1942), 114-116. Also see Hozumi Shichirō, "Sōsenkyo e no kitai" (Expectations for the General Election), Kaizō, 24:4 (April 1942), 180.

63. Endō, 19.

64. Naimushō keihōkyoku hōankachō, "Hōhatsu dai 11 gō" (Security Section Dispatch Number 11), Top Secret, February 10, 1942 in Archive Title 1500 Naimushō keihōkyoku hōanka, Yokusan sōnendan ni taisuru sayoku bunshi no sennyū soshi ni kansuru ken (Preventing Infiltration of the Adults Association by Leftist Elements) Reel 221, Frame 93125.

65. Soshiki oyobi katsudō, 6. Satō's remarks are cited in YKUS, 235-236.

66. See "Yokusan senkyo kantetsu undō sōnendan jisshi yōryō" (Outline for the Adults Association to Implement a Campaign for the Accomplishment of the Yokusan Election), in Soshiki oyobi katsudo, 73-79.

67. Keihōkyoku hōanka, "Saikin ni okeru kokkashugi undō no jōsei" (Recent Conditions in the Nationalist Movement), Top Secret June 16, 1942 in JR 44 Reel 44, Frame 0013.

68. Hōmushō kōan chōsachō, eds. (Justice Ministry Public Safety Investigatory Board), Senzen ni okeru uyoku dantai no jōkyō shiryō ge 2 (Documents of Prewar Right Wing Associations' Conditions 4) (Tokyo: Naikaku insatsukyoku, 1967), 785. Hereafter cited as Senzen, 4.

69. Ibid.

70. TG (February 1942), 70.

71. Senzen, 4,785 .

72. Ibid., 790 and Hōmushō kōan chōsachō, eds., Senzen ni okeru uyoku dantai no jōkyō shiryō jō (Volume 1) (Tokyo: Naikaku insatsukyoku, 1965), 337. Hereafter cited as Senzen, 1.

73. Senzen, 1, 337-338.

74. This paragraph is based on Tokkō dai 2 ka (Thought Police Second Section), "Sōsenkyo ni taisuru kakushin jinei no dōkō" (Tendencies in the Reformist Camp toward the General Election), Secret February 1942 in Archive Title 1468 Reel 213, Frame 82227-82232. The assessment of General Ishiwara comes from Naimushō keihōkyoku, ed., Shōwa jüshichi nen ni okeru shakai undō no jōkyō, 14 (The Current State of Social Movements in 1942, 14) (Tokyo: 1942 rpt. San ichi shobō, 1972), 336. Hereafter cited as SUNJ.

75. Satō, Kaikoroku, 287.

1. NMSS, 2, 294-297.

\section{Chapter Three}

2. Ibid., 746-749 details the evolution of the political secret police. Also interview with Hashimoto Seinosuke. The secret police were abolished under the 1935 election reform but the organization continued to exist under a different 
designation. In the Police Bureau it became the Security Section's Crime Prevention Department (böhanka); the Metropolitan Police Board's Intelligence Section $(j \bar{o} h \bar{o} k a)$; and the prefectural police departments' secretariat (shokishitsu).

3. NMSS, 4, 198. Also see Soma, 136.

4. These untitled, classified reports submitted by Tokyo police chiefs may be found in Archive Title 1464 Gaimushō jōhōka (Foreign Ministry Intelligence Section), Senkyo ni kansuru zassho toji 1942 (Miscellaneous Papers Relating to Elections in 1942) Reel 221, Frames $79613 \mathrm{ff}$.

5. For examples of previous candidate investigations by the police see Keihōkyoku bōhanka, "Shūgiin giin kōhosha keireki shirabe (Shōwa 12-nen 4-gatsu 23-nichi 12-ji)" (Investigations of the Backgrounds of Candidates for the Lower House as of Noon April 23, 1937), Secret April 23, 1937 in Archive Keihōkyoku bōhanka, Sōsenkyo kankei kiroku April 1937 (Records Relating to the April 1937 General Election) Reel 206, Frame 73499-73584. Hashimoto interview. For a different interpretation of these police investigations see TS, 4, 206.

6. Keishicho johoka, "Keishicho jōhōka jimu seiseki," Archive Title 1527 Reel 225, Frame 97202.

7. Keishichō, "Kanjōhō dai 29 gō," Top Secret January 12, 1942 in Archive Title 1468 Reel 213, Frame 81742.

8. See Keishichō jōhōka, "Shōwa 17-nen 4-gatsu 30-nichi senkyo shikō: Shūgiin giin toshite no tekikakusha shirable (rikkōhosha o kibō sesaru mono)" (Investigations of Persons Suitable (Persons Desiring to Become Candidates) as Candidates for the General Election for the Lower House to be Held April 30, 1942), Top Secret January 16, 1942 in Archive Title 1468 Reel 213, Frame 81929-81935: Keishichō, “Tokyo-fu ni okeru rikkōho tekikakusha chōsa” (Investigations of Persons Suitable to Stand as Candidates in Tokyo Prefecture), Top Secret January 27, 1942 in Archive Title 1464 Reel 211, Frame 7969679702: Keishichō, "Tokyo-fu ka ni okeru rikkōho tekikakusha shirable," Top Secret February 5, 1942 in Archive Title 1468 Reel 213, Frame 81870-81877: Keishichō, "Kanjōhō dai 395 gō," Top Secret March 18, 1942 in Archive Title 1469 Naimushō johōka, Showa 17-nen 4-gatsu shikō shügiin giin sōsenkyo jōsei toji: February 9, 1942-May 1, 1942 (Papers Relating to General Elections to the House of Representatives He'd in April 1942) Reel 213, Frame 82590.

9. Hashimoto Seinosuke maintained in my interview that the police had no direct input into the national Political Council recommendation committee.

10. Keihōkyoku keimu kachō (Director Police Affairs Section Police Bureau), "Senkyo torishimari keisatsu kan no kyōyō ni kansuru ken" (Concerning Educational Matters About Police Regulation and Control of the Election), Secret January 31, 1942 in Archive Title 1468 Reel 213, Frame 81823.

11. "Keishichō jōhōka jimu seiseki," Reel 225, Frame 97202-97203.

12. Keihōkyoku, ed., Senkyohan sōsa tansho no jitsurei shū (Collected Factual Examples of Clues for Detecting Election Violations), Restricted: Official Use Only February 1942 in Archive Title 1470 Reel 214, Frame 8355683601 .

13. This paragraph is based on Keihōkyoku keimuka, "Bōhatsu dai 273 gō" (Crime Prevention Section Instruction Number 273), Top Secret February 17, 1942 in Archive Title 1469 Reel 213, Frame 82502-82504; Keishichō, "Kanjōhō dai 296 gō," Top Secret March 11, 1942 in Archive Title 1469 Reel 213, Frame 82555 ff; Keishichō, "Kanjōhō dai 383 gō," Top Secret March 17, 1942 in Archive Title 1469 Reel 213, Frame 82575-82576. 
14. Takemoto Kuramae keisatsu shochō (Takemoto Kuramae Police Chief), “Take jōsei dai 21 gō" (Takemoto Kuramae Situation Report Number 21), Secret February 23, 1942 in Archive Title 1464 Reel 211, Frame 79555-79758. The rumors about restaurant patrons are from Nagai Kafū, 254.

15. Kafū, 255. February 14, 1942 entry.

16. Keihōkyoku keimuka (Imai Hisashi), "Dō-fu-ken keimukachō uchiawasakai gaikyō" (The General Situation of the Prefectural Police Affairs Section Heads' Caucus), February 14, 1942 in Naimu kōsei jihōo (March 1942), 29.

17. Narita Ichirō, "Dō-fu-ken shinkōkachō jimu uchiawasekai ni okeru Narita chihōkyokuchō aisatsu yōshi" (The Essentials of Regional Affairs Bureau Director Narita's Address to the Caucus of Prefectural Promotion Branch Directors), February 26, 1942 in Naimu kösei jiho (March 1942), 27-28. The Home Ministry established prefectural shinkōka in 1938 to promote the community council system. NMSS, 2, 64-65.

18. Tojo Hideki, "Chihō chōkan kaigi ni okeru naikaku sōridaijin kunji" (The Cabinet Prime Minister's Instructions at the National Governors Conference), March 3, 1942 in Naimu kōsei jihō (April 1942), 5-8.

19. Furui danwa, 45.

20. Yuzawa Michio, "Chihō chōkan kaigi ni oekru Naimu daijin kunji yooshi" (The Essentials of the Home Minister's Instructions at the National Governors' Conference), March 4, 1942 in KKS Beikoku henkan monjōNaimushō kankei shiryō (Home Ministry Related Documents in the Archives Returned [to Japan] by the United States, hereafter BHM) Chihō chōkan keisatsu buchō kaigi shorui Shöwa 17-nen (Papers of the 1942 Prefectural Governors' and Police Directors' Conferences), File hen sei 3A 21-5 Document \#8.

21. Shiji jikō (Shügiin giin senkyo jimu no shikō ni kansuru ken) (Matters of Instruction Concerning the Execution of Duties in the Election of Representatives to the Lower House) March 4, 1942 in $K K S$ BHM, File hen sei 3A 15 21-5 Document \# 9.

22. Yuzawa Michio, "Keisatsu buchō kaigi ni oekru Yuzawa Naimu daijin kunji yōshi" (The Essentials of Home Minister Yuzawa's Instructions at the National Police Directors' Conference), March 13, 1942 in KKS BHM, File hen sei 3A 15 21-5 Document \#12.

23. Tomeoka Yukio, "Keisatsu buchō kaigi ni okeru Tomeoka sōkan kunji yōshi” (Director Tomeoka's Essential Instructions at the National Police Directors' Conference), March 14, 1942 in Archive Title 1454 Naimushō jōhōka, Shochō kaigi kankei shorui (Papers Relating to Conferences of Police Chiefs in Japan) Reel 206, Frame 73884-73888.

24. Keihōkyoku, Shiji jikō (Senkyo kankei) Shōwa 17-nen 3-gatsu 14-ka ni-okeru keisatsu buchō jimu uchiawasekai (Matters of Instruction [Election Related] at the Police Directors' Business Conference March 14, 1942) in KKS $B H M$, File hen sei 3A 15 21-5 Document \#15.

25. Matsuzaka Hiromasa, "Keisatsu buchō jimu uchiawasekai ni oekru Matsuzaka kenji kunji" (Procurator Matsuzaka's Instructions at the Police Directors' Business Conference), Secret March 14, 1942 in KKS BHM File hen sei 3A 15 21-5 Document \#18.

26. Cited in Japan Times and Advertiser, April 5, 1942, 1-1; 2-2; 3.

27. Keihōkyoku keimukachō, "Gōgai” (Special Report), Top Secret March 25, 1942 in Archive Title 1469 Reel 213, Frame 82659-82660.

28. Keishichō, "Kanjōhō dai 513 gō," Top Secret March 31, 1942 in Archive Title 1469 Reel 213, Frame 82458-82463. 
29. "Shōwa 17-nen 3-gatsu shisō kensatsukai dō ni okeru shisō kakari kenji shiji yōshi" (The Essential Instructions of the Ideological Section Procurator at the Prefectural Ideological Procurators' Meeting in March 1942), in Archive Title 1521 Kaigi shorui toji-Iwai keisatsuchō (Iwai Police Station [Tottori Prefecture] 1942-Papers on Thought Control) Reel 223, Frame 95589-95618.

30. NMSS, 1, 215-216. Matsuo Takayoshi, "Seiyūkai to Minseitō" (The Seiyūkai Party and the Minseitō Party), in Iwanami kōza, ed., Nihon no rekishi 19 kindai 6 (Tokyo: Iwanami shoten, 1976), 96-100.

31. Hatanaka Shigeo, Shōwa shuppan danatsu shoshi (A Concise History of the Suppression of Publication During the Showa Era) (Tokyo: Tosho shimbun, 1977 ed.), 22-23. Hatanaka (1908- ) was editor of Chūō kōron from 1941 through 1944. The government established the Cabinet Information Committee on June 30, 1936 and amalgamated the army and navy information departments as well as Home Ministry censorship functions. The Committee became the Cabinet Information Department in September 1937, shortly after the outbreak of the Sino-Japanese War. In 1940 it became the Cabinet Information Bureau.

32. Aochi Shin, "Genron danatsu" (Suppression of Free Speech), in Itō, Kataritsugu, 4, 265-268.

33. Nihon jyānaristuo renmei, ed., Genron danatsushi (A History of Suppression of Free Speech) (Tokvo: Ginko shobo, 1949), 117.

34. See "Kiji sashi-tomeru jikō" (Items Prohibited as Articles), cited in Hatanaka, 67-70. See Appendix B for a list of 10 "negative" topics to be avoided.

35. Naimushō keihōkyokuchō, "Shūgiin giin sōsenkyo ni kansuru kiji torishimari ni kansuru ken" (Matters for Control and Management of Articles Concerning the General Election to the Lower House), Secret February 28, 1942 in Archive Title 1470 Reel 214, Frame 83420-83421. See Appendix C for a complete translation.

36. Hatanaka, 70-71.

37. Hayashi, 321-322. Also see Ben-Ami Shillony, "Wartime Japan: A Military Dictatorship?," in Harold Z. Schiffrin, ed., Military and State in Modern Asia (Jerusalem: Jerusalem Academic Press, 1976), 77-83.

38. These observations are taken from Kawada Hidenao, "Yokusan senkyo no shomondai" (Various Problems of the Yokusan Election), Nippon Hyöron, 17:5 (May 1942), 148; Taira Sada, "Chihō toshi no teiryū" (Undercurrents in Regional Cities), Kaizō, 24:5 (May 1942), 178; and Inoue Sōzaburō, "Yokusan senkyo o tsuku (1)" (Striking at the Heart of the Yokusan Election, 1), Ekonomisuto, 20:14 (April 15, 1942), 38.

39. Yoshimura Tadashi, "Shinnin no tōjō o unagase" (Stimulate New Men Appearing on the Scene), Hōchi shimbun, February 21, 1942, 1. Hereafter cited as $H S$. TAS, April 20, 1942, 1.

40. "Kakuchi senkyo keisei-Hokuriku chubu (3)" (Election Conditions in Each Region: North Central Area [3]), Yomiuri shimbun, April 20, 1942, 2. Hereafter cited as YS. "Yokusan senkyo no hattei" (Starting the Yokusan Election), Kokumin shimbun, February 24, 1942, 2. Hereafter KS. "Keimō seyo, kanshō suna" (Enlighten, Don't Interfere), HS, February 27, 1942, 1 and "Ōshuteki senkyo no tessoku" (The Iron Clad Rule for a European Style Election), $H S$, April 6, 1942, 1.

41. Keihōkyokuchō, "Keihōkyoku hakko dai 14 gō" (Police Bureau Instruction Number 14), Top Secret March 1942 in Archive Title 1504 Naimu jikan (Vice Home Minister), Senkyo enzetsukai genron torishimari hyōjun narabi genron no sekkyokuteki shidō yöryō sōfu no ken (Standards for the 
Control and Positive Guidance of Election Campaign Rally Speeches) Reel 221, Frame 93218-93221. See Appendix D for a complete translation.

42. Keishichō, "Kanjōhō dai 492 gō," Top Secret March 29, 1942 in Archive Title 1454 Reel 207, Frame 73942-73944.

43. For a treatment of military and civil police activities in the 1937 general election see Awaya Kentarō, "1936, 37 sōsenkyo ni tsuite" (Concerning the 1936 and 1937 General Elections), Nihonshi kenkyü, 146 (October 1974), 120. I am thankful to Professor Awaya for supplying me with a copy of his article.

44. "Jimu seiseki," Archive Title 1527 Reel 225, Frame 97207-97208 and Keishichō jōhōkachō, "Jōhi dai 1306 gō" (Secret Situation Report Number 1306), Secret April 20, 1937 and "Jōhi dai 1364 gō," Secret April 26, 1937 in Archive Title 1455 Naimushō jōhōka, Shōwa 12-nen 4-gatsu 30-nichi shikō shügiin giin senkyo kankeisho toji (Papers Relating to General Elections to the House of Representatives held on April 30, 1937) Reel 207, Frames 7441174423 and $74741-74755$ respectively.

45. This attitude was pervasive. A Thought Police training manual, for example, stated, "If the ideological war is lost, no matter how superior the military effort, the ultimate result will be similar to Germany's in the previous World War." Keihōkyoku hōanka, Senjika ni okeru kokkashugi undō no torishimari hōshin (Methods for Control of the Nationalist Movement in Wartime) Secret July 1942 in $J R$ 44, Title 3:18, Reel 44, Frame 0004.

46. For an extremely candid report on shortages in farming villages see, Ono Takeo, "Kibō no nōson" (The Hope of the Farming Villages), Kaizō, 24:5 (May 1942), 183-195.

47. Shihōshō hōgōkyoku, ed. (Justice Ministry Rehabilitation Bureau), "Shokuryo fusoku ni ki-in seru kakurui ryūgen" (False Rumors Originating in the Food Shortage), Shisō geppō (Ideological Monthly) Top Secret, \# 92 (March 1942), 11-34. Hereafter cited as $S G$.

48. Yokusan seiji taisei kyōgikai honbu, ed., "Genron shidō yōryō," cited in Kiroku, 158-161.

49. Cited in Tsurumi Shunsuke, ed., Nihon no hyakunen 3, Hateshinaki sensen (Japan's One Hundred Years 3, The Endless Front) (Tokyo: Chikuma shobō, 1962), 180.

50. See Scalapino, 250-251.

\section{Chapter Four}

1. KS, March 10, 1942, 2. Also see Miyako shimbun, March 10, 1942, 2 among others. Hereafter cited as $M S$.

2. Iwabuchi Tatsuo, "Seijiteki shinnin ron" (A Theory of Politically New Men), Kaizō, 24:5 (May 1942), 167: "Sanpeigō-Abe taishō no kaiyu-tōsen dai ichi shugi haisubeshi" (Trench Warfare: The Instruction of General Abe: Avoid the Election First Philosophy), KS, March 11, 1942, 1; YS, April 15, 1942, 1; $M S$, March 10, 1942, 1; $H S$, March 22, 1942, 1.

3. $O A S$, March 19, 1942, 2.

4. Ibid., March 23, 1942 evening ed., 1. Abe Nobuyuki, "Daitōa senka no sōsenkyo" (The General Election of the Greater East Asia War), YS, March 22, 1942, 1. Consult Kiroku, 104 on the reproduction and distribution of this press conference.

5. See, for example, Narita Ichirō, "Daitōa sensō kansui yokusan senkyo kantetsu undō kihon hōsaku" (The Fundamental Method to Inculcate a Yokusan Election for the Greater East Asia War's Accomplishment), Shimin, 37:3 
(March 1942), 8. Okamoto Shigeru, "Daitōa sensō kansui yokusan senkyo kantetsu undō konpon yōko kaisetsu" (An Outline of the Campaign to Inculcate a Yokusan Election for the Greater East Asia War's Accomplishment), Shimin, 37:3 (March 1942), 15-16. Nagano Yoshitatsu, "Daitōa sensō to yokusan senkyo" (The Greater East Asia War and the Yokusan Election), Shimin, 37:3 (March 1942), 39.

6. Kan Tarō, "Ikaga no senkyo de aru ka" (What Kind of Election Is It?), Kōron (April 1942), 48: Ichikawa Kiyotoshi, "Sōsenkyo to seisōnen" (The Election and Young Adults), Chūō kōron, \#656 (April 1942), 26. Ando's remarks are found in Yokogoshi, (2), 45.

7. Refer to Chapter One, note 2.

8. Kanpō gōgai-Shōwa 17-nen 3-gatsu 26-nichi, Dai 79-kai teikoku gikai shügiin giin giji sokkiroku dai 18 go (Official Gazette-79th Plenary Session, March 26, 1942), 258-259. Tojo's reply may be found in Ibid., 259-260. Also consult Naimushō keihōkyoku hōanka, "Kian toji, December 8, 1941-July 16, 1945," in Archive Title 1503 Shūgiin giin Andō Masazumi teishutsu seifu no senkyo taisaku ni kansuru shitsumon ni taisuru tōbensho sōfu no ken (Reply to Questions Submitted by Ando Masazumi of the House of Representatives Relating to the Government's Election Policy) Reel 221, Frame 93163-93201.

9. Andō referred to a Tojo speech in Advertiser, March 9, 1942, 1-1.

10. In Nazi Germany opponents of the regime did vanish. The Gestapo Law of February 1936 absolved the Gestapo from any administrative court review of its actions thus placing it above the rule of law. In 1940, the German Justice Ministry agreed that acquitted persons or released prisoners suspected of political offenses should automatically be handed over to the Gestapo. See H. Krausnick, ed., Anatomy of the SS State (London: Collins \& Sons, Ltd., 1968).

11. Kanpō gōgai-Shōwa 17-nen 3-gatsu 26-nichi, Dai 79-kai teikoku gikai kizokuin giji sokkiroku dai 16 go (Official Gazette-Imperial Diet House of Peers March 26, 1942), 232-235.

12. Kido Kōichi, Kido Köichi nikki 2 (Kidō Kōichi Diary) (Tokyo: Tokyo daigaku shuppan kai, 1966), 952. Kido, in his capacity as imperial factotum, received regular reports on the election from Yuzawa, Yamazaki Iwao, and Imamatsu. Additionally, he received unofficial but nonetheless accurate accounts of Political Council activity from his daughter's father-in-law, Abe Nobuyuki. Abe visited in his official capacity as well.

13. Ozaki Yukio, "Tojo shushō ni ataeraru kōkaijō" (An Open Letter to Prime Minister Tojo), April 1942 in GDSSR, 42, 1090. Also see Ozaki Yukio, Minken tōso 70-nen (The 70 Year Struggle for Human Rights) (Tokyo: Yomiuri shimbun, 1952), 186.

14. TG (March 1942), 94-101.

15. Cited in Yokogoshi, (2), 38.

16. Kiroku, 36.

17. Keihōkyoku, "Hōhatsukan dai 13 gō," Top Secret March 23, 1942 in Archive Title 1470 Reel 214, Frame 83757-83767. A member of the Tokyo Political Council branch passed this document to the police.

18. The other committee members were Endō Ryūsaku, Fujiyama Aiichirō, Godō Takuo, Gotō Fumio, Hirai Hachisaburō, Ida Iwakusa, Koiso Kuniaki, Ōta Kōzō, Sengoku Kotarō, Shimomura Hiroshi, Suetsugu Nobumasa, Takahashi Sankichi, Taki Masao, Tanaka Tokichi, and Yokoyama Sukenari.

19. Ichikawa, 22 and Shimuzu Shin, Nihon kokumin undo no kihon mon- 
dai (Fundamental Problems of the Japanese National Movement) (Tokyo: Kenbun shoin, 1943), 94.

20. Aritake, Maeda, 450.

21. TG (April 1942), 56 and SUNJ, 14, 337.

22. $K S$, March 21, 1942, 1. Exact figures remain difficult to find. NCS, for example, apparently listed branch members according to their primary occupation. If a member was an IRAA town chief he would be listed as such and not, although quite possible, as a Reservist Association member or Adults Association sub-leader. These positions were not mutually exclusive and overlapping membership appears to have been the rule not the exception.

23. Nakatani Takeo, Senji gikai shi (A History of the Wartime Diet) (Tokyo: Minzoku to seijisha, 1975), 81-82.

24. Author's interview with former Gunma Governor Murata Gōrō, February 14,1977 in Tokyo.

25. Author's interview with former Chiba Governor Fujiwara Takeo in Tokyo, February 22, 1977.

26. Otani Keijirō, Shōwa kempeishi (A History of the Military Police in the Showa Reign) (Tokyo: Misuzu shobō, 1966), 450-451. However, Hashimoto Seinosuke maintained that the army had no direct influence on candidate recommendations.

27. Keishichō, "Kanjōhō dai 518 gō," Top Secret March 30, 1942 in Archive Title 1468 Reel 213, Frame 82427-82431.

28. Aiichi and Chiba branches also submitted Tōhōkai incumbents and Saga, Kagawa, and Hyōgo branches endorsed Dōkōkai incumbents. See $M S$, April 1, 1942 evening and morning editions, 1 and $M S$, April 2, 1942, 1.

29. "Yokusan senkyo hōkokusho (3)" (Various Reports on the Yokusan Election 3), Tokyo Nichi Nichi shimbun, April 16, 1942, 2. Hereafter TNNS. "Yokusan senkyo hōkokusho (4)," TNNS, April 17, 1942, 2: Endō, 21-22 and "Yokusan senkyo o genchi ni miru" (The Yokusan Election Seen On the Spot), TAS, April 16, 1942, 2.

30. $M S$, April 1, 1942, evening ed., 1 and $M S$, April 2, 1942, 1.

31. $M S$, April 1, 1942, 1.

32. Kiroku, 39-40. Originally, the Council on April 5, 1942 endorsed 469 candidates including 231 incumbents (204 Yokudō). Seven of those recommended, however, declined the nomination and after replacing only four of these reluctant seven, the final total was 466 recommended candidates.

33. MS, April 6, 1942, 1: Advertiser, March 31, 1942, 2-5. "Seiji jōsei," JR 44 Reel 44, Frame 0011.

34. Hayashi, 306.

35. "Suisen senkyo no dōkō (jō)" (Tendencies in the Recommended Election, 1), $M S$, April 6, 1942, 1.

36. $O A S$, April 24, 1942, 4.

37. Advertiser, April 6, 1942, 2-3 and "Senkyo undō kaishi suru" (The Election Campaign Begins), TNNS, April 5, 1942, 1.

38. Suda Teiichi, Kazami Akira to sono jidai (Kazami Akira and His Era) (Tokyo: Misuzu shobō, 1965), 150. Kamazi was also the target of a vicious campaign sponsored by the right wing Ikken kinnō undō whose leaders regarded Kazami as an arch-enemy. See, Senzen, 4, 791.

39. "Rikkōhosha no iro wake" (The Dividing Coloration of Standing Candidates), TNNS, April 21, 1942, 2; OAS, April 24, 1942, 2; "Suisen senkyo no dōkō (ge)," $M S$, April 7, 1942, 1. 
40. Kiroku, 303-307.

41. "Suisen," $M S$, April 7, 1942, 1.

42. $M S$, April 7, 1942, 1.

43. Tsukui Tatsuo, ed., Shōwa jūhachinendo shimoki han Nihon seiji nenpō dai 3 go (Part Three of the Japan Political Yearbook for the Second Half of 1943) (Tokyo: Shōwa kankōkai, 1942), 139.

44. Advertiser, April 7, 1942, evening ed., 1-1.

45. "Kokkashugi undō no jōsei," JR 44 Title 3:16 Reel 44, 0013.

46. Cited in $M S$, March 18, 1942, 2.

47. Senzen, 4, 789-790 and Senzen, 2, 139.

48. Naimushō keihōkyoku hōanka, "Dai 21 kai sōsenkyo ni okeru kokkashugi dantai kankei kōhosha seiseki shirabe" (Investigations of the Candidate Results of Those Having Connections with Nationalist Organizations in the 21st General Election), Secret May 4, 1942 in JR 44 Reel 44, Frame 0029-0037. The 17 included 15 Yokudo, one First Lobby, and one former Diet member.

49. TG (April 1942), 57.

50. "Dai 21 kai ...," lists 196 reform rightists as candidates with 28 recommended and 168 not recommended. The 1937 figures are from TG (May 1937), 65-71.

51. "Dai 21 kai . . . ", Frame 0029-0037.

52. "Seiji jōsei," JR 44 Reel 44, Frame 0109-0110.

53. Keishichō, "Yokudō igai no tekikaku kōhosha chōsa" (Investigations of Suitable Candidates Outside the Yokudō), in Archive Title 1469 Reel 213, Frame 82653. On the decrease of former Socialist Masses Party candidates see, Naimushō keihōkyoku hōanka, "Sōsenkyo ni arawaretaru kyū Shakai taishūtō kei seiryoku no shōchō ni kansuru ken" (Matters Related to the Prosperity and Decay of the Influence of [Candidates] Connected with the Former Socialist Masses Party in the Election), May 11, 1942 in Archive Title 1470 Reel 214, Frame 83862. Saitō's speech may be found in Kaisen keii, 1, 485-491.

54. Matsuo Kikutarō, "Yokusan senkyo to suisen seidō" (The Yokusan Election and the Recommendation System), Hōso kōron, 14:4 \#416 (April 1942), 16. Kawamura Yukai, "Suisen seidō ron" (A Theory of the Recommended Election System), Kaizō, 24:4 (April 1942), 39. Also see YKUS, 434.

55. Inoue, "Yokusan ... tsuku (2)," 36-37. In previous universal male suffrage elections there were the following numbers of candidates:

$\begin{array}{ccccc}1928 & 965 & & & \\ 1930 & 840 & & & \\ 1932 & 779 & & & \\ 1936 & 879 & 387 \text { new } & 387 \text { incumbent } & 104 \text { former } \\ 1937 & 826 & 321 \text { " }^{\prime \prime} & 424 & 81 \text { " }\end{array}$

56. Advertiser, April 13, 1942, 2-8. Candidate filing figures are from Asahi shimbunsha, ed., Yokusan senkyo taikan (A Comprehensive Yokusan Election Overview) (Tokyo: Asahi shimbunsha, 1942), 15. According to Article 68 of the Election Law, all candidates posted a mandatory bond that was subject to confiscation should the candidate receive less than $10 \%$ of the votes cast in his district.

57. $O A S$, April 24, 1942, 4 .

58. Cited in Advertiser, April 21, 1942, 1-2.

59. Fujita Yoshimitsu, "Konji sōsenkyo no gō tokucho" (The Five Special Characteristics of this General Election), Shükan Asahi (May 3, 1942), 17; TNNS, April 16, 1942, 2; OAS, April 5, 1942, 1. 
60. Fujita, "Konji," 17. On the former parties' domination of the candidate nomination process see Peter Duus, "The Era of Party Rule: Japan, 1905-1932," in James B. Crowley, ed., Modern East Asia: Essays in Interpretation (New York: Harcourt, Brace, \& World, 1970), 195.

61. "Sōsenkyo no ishiki" (An Awareness of the General Election), TNNS, April 8, 1942, 1.

62. Author's interview with Akao Bin in Tokyo March 4, 1977.

63. TNNS, April 8, 1942, 1.

64. On "power aspirants" and the 1942 election see Ishida, 33.

\section{Chapter Five}

1. Shimuzu Shin, ed., Nihon kokumin undō nenshi dai 1-gō (The Japan National Movement Annual Report Part 1) (Tokyo: kenbun shoin, 1943), 105.

2. $K S$, April 19, 1942, 1.

3. Kafū, 250.

4. The IRAA's Gotō Fumio and the Adults Association's Andō Kisaburō told the rally that voters had to elect candidates possessing a national outlook and warned voters to beware of "the purveyors of liberal British and American ideas" who obstructed the war effort. Cited in HS, March 16, 1942, 2.

5. Naimushō chihōkyoku shinkōka, "Kaku dō-fu-ken ni okeru yokusan senkyo kantetsu undō no seika, 2" (Results in Each Prefecture of the Campaign to Inculcate a Yokusan Election), Shimin, 37:8 (August, 1942), 27-35.

6. "Taisei yokusankai no sōsenkyo taisaku" (The IRAA's General Election Strategy), February 19, 1942 in Archive Title 1470 Reel 214, Frame 83426 and Keishichō, "Kanjōhō dai 290 gō," Secret March 10, 1942 in Archive Title 1468 Reel 213, Frame 82258-82259.

7. "Yokusan senkyo jun, tōben, 4" (The Rules for a Yokusan Election and Answers to Questions [About Them]), TNNS, March 27, 1942, 4.

8. YKUS, 236-237. "Jikyoku memō: Taisei yokusankai senkyo kankei taisaku" (Situation Meomo: The IRAA's Election Related Strategy), Kokusaku kenkyükai shühō, \# 9 (March 1942), 9.

9. See MS, March 4, 1942, 7 and March 8, 1942, 2; Advertiser March 23, 1942, 4-4. Shinkoka, "Seika, 2," 30. Sample slogans included, "Use Your Vote to Build Greater East Asia," "Don't Shame the Yasukuni War Dead," "Reverently Assist Carrying Out the Imperial Rescript," and "This Vote Builds East Asia."

10. YKUS, 594, 794, and 607-608.

11. Ibid., 839. Cf., "Yokusan senkyo genchi ni miru, 4," $T A S$, April 19, 1942,2

12. YKUS, 580-669, and 642. "Yokusan senkyo genchi ni miru, 1," TAS, April 16, 1942, 2 and "Yokusan senkyo hon'ei o miru, 3" (A Look at Yokusan Election Headquarters), TNNS, April 16, 1942, 2.

13. "Genchi ni miru, 4," TAS, April 19, 1942, 2 and YKUS, 671.

14. Ibid., 705, 694-695, and 655. "Hōkokusho, 1," TNNS, April 14, 1942, 2.

15. Shinkōka, "Seika, 2," 27. Similar attractions held in 17 prefectures recorded good results.

16. YKUS, 437 and 599. Newspaper accounts of Adults Association activity may be found in "Hōkokusho, 1," TNNS, April 14, 1942, and April 15, 1942, 2; "Senkyo jōsei tenbyō" (Sketches of Election Conditions), MS, April 20, 1942, 2; "Genchi o miru, 2," $O A S$, April 17, 1942, 2 and April 19, 1942, 2. 
17. "Genchi miru, 2," TAS, April 17, 1942, 2, and April 19, 1942, 2. Also see Endō, 22.

18. "Hōkokusho, 1," TNNS, April 14, 1942, 2 and April 16, 1942, 2.

19. See Kiroku, 95-105, 115-151, 163-166. Yabe's remark is found in Yabe Teiji nikki kankōkai, ed., Yabe Teiji nikki: Ichō no kan (Yabe Teiji's Diary: Gingko Tree Volume) (Toyko: Yomiuri shimbun, 1974), 522. Diary entry for April 29, 1942.

20. Kiroku, 95-100.

21. Otani, 450-451. Miki Takeo, "Hisuisen yokusan senkyo" (An Unrecommended Yokusan Election), in Mikuni Ichirō, ed., Shōwa shi tanbō, 4, Shōwa gōki (Searching Showa History, 4, Later Showa) (Tokyo: Banchō shobō, 1974), 16. Interview with Hashimoto Seinosuke. The 10 million yen figure is from Masuo Kato, The Lost War (New York: Alfred A. Knopf, 1946), 103.

22. Fujita, Senkyo, 17; Advertiser, April 21, 1942, 1-2 and April 22, 1942 evening ed., 1-3; YS, April 21, 1942, 1.

23. YS, April 21, 1942, 1.

24. Kiroku, 115-116.

25. Hashimoto sokkiroku, 18.

26. For examples of Dōkōkai support for the war effort see Andō Masazumi, "Senkyo kōhō" (Election Announcement), April 1942 and Hatoyama Ichirō, "Senkyo kōho," April 1942 in Shōwa 17-nen 4-gatsu shügiin senkyo kōhō Tokyo-fu dai 1, 2, $3 \mathrm{ku}$, dai 1 bu (Election Announcements for the First, Second, and Third Tokyo Districts for the April 1942 Lower House Election, Part 1) uncatalogued, n. pag. These documents are located at the Tokyo Shisei chösakai shōzō (Municipal Systems Investigatory Society). Also refer to Ozaki Yukio, "Saigō no gōhokō ni tsuki senkyonin shokun ni gōsōdan" (An Honorable Proposal to the Gentlemen of the Electorate Concerning My Final Honorable Public Service), April 1942 in GDSSR, 42, 1091-1097.

27. YKUS, 440.

28. In that sense, I agree with Nakamura Kikuo's interpretation that the Meiji Constitution acted as a bulwark against fascism in prewar Japan. See Nakamura Kikuo, Tennōsei fuashizumu ron (A Theory of Imperial System Fascism) (Tokyo: Hara shobō, 1967), 204.

29. KS, April 17, 1942, 2.

30. "Yokusan senkyo no seiseki bunseki" (An Analysis of the Yokusan Election Results), Ekonomisuto, 20:18 (May 13, 1942), 32.

31. Naimushō jōhōka, "Shōwa 17-nen 4-gatsu 30-nichi shikō shūgiin giin sōsenkyo ni okeru senkyo kanshō mondai, bekki 4, Kakujin betsu ikō" (Problems of Interference in the General Election for the Lower House Held April 30, 1942, Appendix D, Individuals' Separate Opinions), Top Secret August 20, 1942 in Archive Title 1472 Naimushō jōhōka, Shōwa 17-nen 4-gatsu 30-nichi shikō shügiin giin sōsenkyo kansho mondai Reel 214, Frame 84105-84108.

32. Naimushō jōhōka, "Senkyo ihan jiken toshite kokusho, kokuhatsu seru mono, bekki 2" (Appendix B, Accusations and Indictments of Election Violation Incidents), Top Secret August 20, 1942 in Archive Title 1472 Reel 214, Frame 84046.

33. Naimushō jōhōka, "Senkyo mukō no soshō jiken" (Incidents of Litigation for Election Nullification), Top Secret August 20, 1942 in Ibid., Frame 84029 and "Kakujin betsu," Frame 84105-84107. The nullified ballot quotation is taken from, Shihōsho hōgōkyoku, ed., "Konji shūgiin giin sōsenkyo ni okeru mukō tokuhyō o tojite mitaru kokumin shisō no dōkō" (Tendencies in the 
People's Thought as Seen in Invalidated Ballots Occurring in This General Election to the Lower House), Top Secret SG, \# 94 (May 1942), 1-25.

34. Keishichō keimuka kyōyō kakari (Metropolitan Police Board Police Affairs Branch Education Section), "Benshi Ozaki Yukio enzetsu sokkiroku" (A Stenographic Record of Speaker Ozaki Yukio's Speech), April 1942 in GDSSR, 42, 1098-1106.

35. Keihōkyoku hōanka, "Tōhōkai no dōkō" (Tendencies of the Tōhōkai), Top Secret June 19, 1942 in JR 44 Reel 44, Frame 0017-0021. "Kokkashugi jōsei," Ibid., Frame 0010.

36. SUNJ, 216. Keihōkyoku hōanka, "Dai Nippon Sekiseikai jukukaku gumi ato no dōkō" (Tendencies of the Greater Japan Sincerity Association After Its Reversion to a Private Group), Top Secret June 19, 1942 in JR 44 Reel 44, Frame 0022-0023.

37. TG (April 1942), 54; SUNJ, 336 and Senzen, 4, 788.

38. SUNJ, 336.

39. Senzen, 1, 139 and 608; Senzen, 4, 789-790 and SUNJ, 337.

40. "Kokkashugi jōsei," Frame 0003.

41. Senzen, 3, 787 .

42. SUNJ, 336-338; Senzen, 3, 337; TG (April 1942), 54; "Kokkashugi," Frame 0011.

43. For a different view see Ienaga Saburō, The Pacific War: World War II and the Japanese, 1931-1945 (New York: Pantheon Books, 1978), 111.

44. Tojo, for instance, assumed the post of Home Minister in 1941 to preserve domestic order from rightist disruptions should Japanese-U.S. negotiations prove successful. See the minutes of the December 1, 1941 Imperial Conference in Sugiyama Gen, Sugiyama memō (The Sugiyama Memo) (Tokyo: Hara shobō, 1967), 1, 558-560.

45. Tsukui, Jüshichinen, 228.

46. Shimizu, Nenshi, 105.

47. "Genchi ni miru, 1," $O A S$, April 16, 1942, 2; "Yokusan senkyo no jitsujō o miru-Tokyo no kan, 1" (Looking at the Yokusan Election's Actual Conditions: The Tokyo Perspective, 1), YS, April 27, 1942, 1; MS, April 17, $1942,2$.

48. "Jitsujō ... Kinki no kan" (The Kinki Region Perspective), YS, April 22, 1942, 2; "Kyōsakō ni kan, jō" (The Outlook in Kyoto, Osaka, and Kobe, 1), $H S$, April 20, 1942, 2.

49. Taira Sada, "Chihō toshi no teiryū" (Regional Cities Undercurrents), Kaizō, 24:5 (May 1942), 178.

50. "Hokuriku no kan" (Hokuriku District Perspective), HS, April 18, $1942,2$.

51. "Hōkokusho, 4," TNNS, April 17, 1942, 2.

52. "Hokuriku chūbu no kan" (Hokuriku and Chubu District Perspectives), YS, April 20, 1942, 1.

53. "Kakuchi senkyo keisei," YS, April 10, 1942, 2.

54. "Genchi ni miru, 2," $O A S$, April 17, 1942, 2 and "Kyushu no kan" (Kyushu Perspective), HS, April 15, 1942, 2.

55. Robert Guillain, Le Peuple Japonais et la Guerre Choses vues 19391946 (Paris: Rene Julliard, 1947), 58 and 67.

56. "Jimu seiseki," Archive Title 1527 Reel 225, Frame 97239-97240.

57. See Sakagami Nobuo, "Yokusan senkyo to Ozaki Yukio, 4" (The Yokusan Election and Ozaki Yukio, 4), Sekai to gikai \#58 (April 1966), 32; 
Noyori Hideuchi, "Tekiki no raishu to sōsenkyo" (The Coming of the Enemy Planes and the General Election), in Noyori Hideuchi, ed., Senso to senkyo (War and Election) (Tokyo: Shubunkaku shobō, 1942), 120; Yuzawa Michio, "Naisō meishi" (Home Minister Yuzawa's Statement), KS, April 21, 1942, 1; Nakano Yasuo, Seijika Nakano Seigō, 2 (The Politician Nakano Seigō) (Tokyo: Shinkō kaku shobō, 1971), 610.

58. Kiroku, 163.

59. Noyori, "Tekiki," $119-120$ and $M S$, April 20, 1942, 1 on the air raid's "benefits." The raid as a campaign topic was related to the author by former recommended candidate Imamaki Yoshio (1897- ) in an interview in Tokyo February 15, 1977.

60. "Kokkashugi jōsei," JR 44, Frame 0005.

61. Kiroku, 163.

62. Furui Yoshimi interview.

63. TNNS, April 21, 1942, 1.

64. Advertiser, April 21, 1942, evening ed., 2-2.

65. TNNS, April 21, 1942, evening ed., 1. The limit on campaign rallies was national, but varied by prefecture. Hokkaidō, for example, set a limit of 80 rallies per candidate but neighboring Aomori placed it at 100 . Even within prefectures differences occurred as Ibaraki's Second District allowed 60 rallies but the Third Constituency only 50 per candidate. $O A S$, April 18, 1942, 2.

66. Keishichō, "Shōwa 11-nen 2-gatsu shikō shūgiin giin sōsenkyo enzetsukai kaisei dosū shirabe" (Investigations of the Openings and Attendance at Campaign Rallies During the Lower House General Election Held February 1936), Secret 1936 in $J R$ Title 3:10 Keishichō, Senkyo undō no jokyō, 1936 (1936 Election Campaign Conditions) Reel 43, Frame 0126.

67. "Jōhi 1306 gō," and "Jōhi 1364 gō."

68. Keishichō, "Enzetsukai nyūjōsha kazu oyobi hikaku" (Attendance Figures for Campaign Rallies and a Comparison of Those Figures), Secret 1943 in Orien Japan Reel 37:3, Frame 373371.

69. Male Koreans residing in Japan were enfranchised if, prior to the 1928 universal male suffrage provisions, they met the voter tax qualification. Until 1928, no Korean ever did. Since 1932, Korean script (Hangul) had been in use on bi-lingual campaign posters and ballots. See, Tanaka Hiroshi, "Nihon no chokuminchi shihaika ni okeru kokuseki kankei no keii: Taiwan Chōsen ni kansuru sanseiken to heieki gimu o megutte" (Particulars Relating to Nationality under Japan's Colonial Rule: Viewed from the Right of Political Participation and Military Service Responsibility for Taiwan and Korea), Aiichi kenritsu daigaku gaikokugō gakubu kiyō, 9 (December 1974), 70-75. I am indebted to Mr. Nakanmura Hisashi of the Ajia keizai kenkyūjō (Asian Economic Research Association) for providing me with a copy of this article. On Pak's 1942 campaign see Ryōgoku keisatsuchō (Ryōgoku Police Chief), "Ryō jōhi 2632 gō," Secret April 18, 1942, in Archive, Title 1469 Reel 214, Frame 83032-83033; Keishichō, "Kanjōhō 750 gō," Top Secret April 24, 1942 in Ibid., Frame 8312183125; "Ryōjōhi dai 323 gō," Secret April 29, 1942, Ibid., Frame 83273.

70. Cited in Advertiser, April 6, 1942, 2-1.

71. Naimushō, "Kantetsu seyo yokusan senkyo" (Inculcate a Yokusan Election), Shühō, \#285 (March 25, 1942), 2-7.

72. Cited in NCS, 135-141.

73. These untitled, handwritten statements are in Archive Title 1464 Reel 
211, Frame 80087-Reel 212, Frame 80427. Also see $T A S$, April 28, 1942, 1 for the extensive, front-page press treatment afforded these speeches.

\section{Chapter Six}

1. For examples of this widespread interpretation see Yui Masaomi, "Taiheiyō sensō" (The Pacific War), in Iwanami henshūbu, ed., Iwanami kōza Nihon no rekishi, 21 kindai 8 (Tokyo: Iwanami shoten, 1977), 43-44, 59-71: TS, 4, 210; Hasegawa, 154-155, 165-166; United States Army, Far East Command, Intelligence, Civil Intelligence Section, "The Brocade Banner: The Story of Japanese Nationalism," Special Report. Mimeographed, 1946, 123; Scalapino, 254 note 3. Scalapino dismisses the 1942 election as having "no significance" in Japan's electoral development because "it was state sponsored, with only one party (sic) participating."

2. Kawai Eijirō (1891-1944), also a Tokyo Imperial University faculty member, in 1938 had criticized then Education Minister former General Araki Sadao (1877-1966) and subsequently Kawai became embroiled in disputes with rightist professors on campus. In 1939, the Education Ministry censored Kawai's writings and indicted him. Tokyo University President Hirai decided to suspend both Kawai and his chief adversary during the judicial proceedings. Ultimately, in 1943 Kawai was found guilty. Jiten, 93.

3. Ōgushi Toyō, "Bunka to seiji no mondai" (Problems of Culture and Politics), Chūō kōron, 57:5 (May 1942), 76.

4. Author's interview with Rōyama Masamichi January 29, 1977 in Tokyo.

5. Rōyama Masamichi, "Kaku tatakai kaku omou" (Fighting This Way, Thinking This Way), Chūō kōron, 57:6 (June 1942), 76.

6. "Sōsenkyo kakuchi jōsei tenbō, 5" (Observations on Various Locations General Election Conditions), HS, March 16, 1942, 2.

7. "Senkyo jōsei tenbyō," MS, April 13, 1942, 2; Kakuchi no chikurokusen jōkyō" (Various Locations' Election Campaign Conditions), KS, April 13, 1942, 1; "Abunai suisen kōhosha" (Recommended Candidates in Danger), HS, April 26, 1942, 7.

8. Rōyama interview. Professor Royama stated that he received no assistance from any secret election fund during his 1942 election campaign.

9. Rōyama, 79 and interview.

10. Murata interview.

11. Naimushō jōhōka, "Senkyo kanshō mondai, bekki 4, Kakujin betsu iko" (Problems of Election Interference, Appendix D, Individuals Separate Opinions), Top Secret August 20, 1942 in Archive Reel 214, Frame 84106-84107.

12. Asō Hisashi, the Socialist Masses Party leaders and top vote getter in 1937, had died as had the Minesitō politician Shiba Teikichi (1869-1939). Katō Kanju (1892- ) was barred from becoming a candidate because of his arrest and conviction in the so-called "Popular Front Movement." The incident was the nationwide round-up of 400 Farmer-Laborer faction members of the $\mathrm{Mu}$ santō on December 15, 1937 for spreading Comintern propaganda, anti-war propaganda, and not cooperating with imperial policy. Katō was sentenced to three years. See Totten, 171 and Jiten, 296. Finally, Miwa Jyūsō had decided against entering the election.

13. "Yokusan senkyo genchi hōkokusho, Tokyo" (On the Scene Reports of the Yokusan Election, Tokyo), TNNS, April 20, 1942, 1 and "Yokusan kaku fu ken dō senkyo hokoku-higashi Nippon" (A Report of Each Prefecture's Yo- 
kusan Election: Eastern Japan), TNNS, April 29, 1942, 4; “Tokyo shichi ku no tembyō" (Sketches of the Seven Tokyo Districts), HS, April 24, 1942, 6.

14. "Yokusan senkyo o tataki isai no kōhō" (Simultaneous Reports of the Struggle in the Yokusan Election), TNNS, April 27, 1942, 2.

15. "Hōkokusho," TNNS, April 20, 1942, 1.

16. "Jimu seiseki," Archive Title 1527 Reel 225, Frame 97207.

17. TNNS, May 4, 1942, 2.

18. RG 331, SCAP, IPS Case \# 180 Shioden Nobutaka, "Interrogation of Shioden Nobutaka," 6-8. When asked by his interrogators about sources of campaign financing, Shioden replied that supporters told him not to ask about such matters.

19. Kobayashi Masayuki, "Nihon hanyudaiyashugi no genryu to Mitsukawa Kametarō, 1 \& 2" (The Sources of Japanese Anti-Semitism and Mitsukawa Kametarō, Parts 1 \& 2), Kaigai jihōo, 21:11 (November 1973), 5 and 22:2 (February 1974), 64. I am grateful to Mr. Ōkubo Genji for supplying me with a copy of these articles.

20. $O A S$, May 2, 1942, 6 .

21. Yamaura Kanichi, "Gikai shinnin ron" (A Theory of a 'New Man' Diet), Chūō kōron, 57:6 (June 1942), 74.

22. Keishichō jōhōkachō, "Showa 17-nen 4-gatsu 30-nichi shikō dai 21 kai shūgiin giin sōsenkyo ni okeru kaku sho betsu undō jōsei dai 5-ku 4-gatsu 24-ka genzai" (Documents of Campaign Conditions for Individual Police Stations During the 21st General Election for the Lower House Executed on April 30, 1942), Top Secret April 24, 1942 in Archive Title 1467 Reel 212, Frames 81316, 81341, $81377,81395,81427,81443$, and 81461 for the reports by the East Choffu, Shibuya, Yoyogi, Nakano, and Ogikubo Police Stations.

23. Shioden Nobutaka, "Senkyo kōhō," in Shūgiin giin senkyo kōhō Tokyo$f u$ dai 4, 5-ku (Fourth and Fifth Tokyo Prefecture District Election Announcements for the Lower House) April 1942 at Chisei kaikan Document 23. Also see Shioden's campaign posters as "Showa 17-nen 4-gatsu 30-nichi shikō shūgiin giin senkyo Tokyo-fu dai 5-ku kōhōsha bunsho" (Candidates' Materials From Tokyo Prefecture's Fifth District for the April 30, 1942 Election to the Lower House), at Chisei kaikan, Document \#9.

24. Shioden Nobutaka, "Sōsenkyo to watakushi" (The General Election and Me), Shükan Asahi (April 29, 1942), 10.

25. Izawa Hiroshi, "Daigishi tekikakusei no kyosatsu" (Consideration of Suitable Characteristics for Representatives), Bungei shunjū, 25:4 (April 1942), 50-53.

26. Irokawa Taikichi, Aru Shōwa shi (One Showa History) (Tokyo: Chūō kōron, 1975), 91-92. Also see Kiyosawa Kiyoshi, Ankoku nikki (Dark Diary) (Tokyo: Tōyō keizai shinpōsha, 1954), 81, 89, 99, and 125 for examples of the Japanese press printing viciously anti-Semitic remarks.

27. Tsukui, representing splinter reform-rightist associations, had finished last in 1936 and 1937.

28. Author's correspondence with Tsukui Tatsuo, September 16, 1976.

29. Tsukui Tatsuo-shi danwa sokkiroku (Stenographic Record of a Conversation with Tsukui Tatsuo) Nihon kindai shiryō kenkyükai, 1974, 163.

30. Tsukui Tatsuo, "Kuhai no benjiru" (Telling About the Bitter Cup), Chūō kōron, 57:6 (June 1942), 83.

31. Tsukui danwa, 163. 
32. Shibuya keisatsuchō, "Shibujōhi dai 1930 gō," Secret April 29, 1942 in Archive Reel 214, Frame 83299.

33. Tsukui danwa, 162-163 and Tsukui correspondence.

34. The three reform rightists were Kodama, the Tōhōkai's Honryō Shinjiro, and the Sekiseikai's Shinoda Yasoya (1897-?).

35. Morinaga Ezaburō, "Ozaki Yukio fukei jiken" (The Ozaki Yukio Disrespect Incident), Högaku seminā, \#196 (April 1972), 123.

36. Hisamatsu keisatsuchō, "Hisajōhi 1107 gō," Secret April 8, 1942 and "Hisajōhi 1266 gō," Secret April 22, 1942 in Archive, Reel 214, Frame 8302083021 and 83168-83169 respectively. Ozaki, Minken, 185 and Wägatsuma Sakae, Nihon seiji hanketsu shiroku-Shöwa gō (A Documentary Record of Japanese Courts' Political Verdicts: Later Shōwa) (Tokyo: Dai ichi shuppan kabushiki kaisha, 1970), 483.

37. According to Ozaki's account, he was well treated at the detention center. Minken, 184-186.

38. $T A S$, April 23, 1942, 3; $T A S$, April 24, 1942 evening ed., 2; $T A S$, April 26, 1942, 3.

39. Kido nikki, 2, 958.

40. Kiyosawa, 151.

41. On the legal proceedings of the Ozaki case, see Tokyo keiji chihō saibansho (Tokyo Criminal District Courthouse), "Ozaki Yukio ni taisuru fukei jiken yoshin saishū kettei" (The Final Decision from the Preliminary Examination of the Accused Ozaki Yukio's Disrespect Incident), July 1942 in GDSSR 42, 1117-1118. Tokyo keiji chihō saibansho, "Ozaki Yukio ni taisuru fukei hikoku jiken dai-isshin hanketsu" (The Verdict in the First Trial of the Accused Ozaki Yukio's Disrespect Incident), December 1942 in Ibid., 11541159 and Saibansho shoki (Court Secretariat), "Ozaki Yukio ni taisuru fukei hikoku jiken Taishin'in hanketsu" (The Verdict of the Supreme Court in the Accused Ozaki Yukio's Disrespect Case), June 1944 in Ibid., 1169-1174.

42. Imamaki interview. Dr. Imamaki won election as a recommended candidate in 1942 .

43. TG (March 1942), 78-79.

44. For Nakano's itinerary see “Tōhōkai Nakano Seigō no senkyo enzetsu" (The Töhōkai's Nakano Seigō's Election Speeches), in Archive Title 1464 Reel 211, Frame 79897. Also see Nakano, Seijika, 2, 610 for Nakano's jiban's role in his campaign.

45. Senzen, 3, 132 and SUNJ, 197.

46. SUNJ, 197 and TG (April 1942), 54-55.

47. "Kokkashugi," JR 44 Reel 44, Frame 0010 and "Tōhōkai," Ibid., 00170018. TG (April 1942), 55.

48. TG (April 1942), 47 and Nakano, 600.

49. "Senkyo mukō," and "Kakujin betsu," in Archive Title 1472 Reel 214, Frame 84028-84034 and 84116 respectively. "Tōhōkai," 0020.

50. “Tōsen mukō," Title 1472 Reel 214, Frame 84107-84108.

51. Odagiri Hideo and Fukuoka Ikichi, eds., Shōwa shoseki/shimbun/ zasshi hakkin nenpō (Censored Publications/Newspapers/Magazines of the Shōwa Period) (Tokyo: Meiji bunken, 1967), 4, 884, 886, 887, and 900.

52. Senzen, 3, 811 and SUNI, 269 and 336.

53. Miki, "'Hisuisen'," 11.

54. This equation of independents with traitors occurred nationally, espe- 
cially with candidates who were identified in the popular mind as "liberal" like Ozaki, Hatoyama, or Saitō Takao.

55. "Chikurokusen, 5," KS, April 16, 1942, 2; "Hōkoku," TNNS, April 28, 1942, 2.

56. "Honjōhi dai 1390 gō," "Honjōhi 2036 gō," and "Hisajōhi 1266 gō," in Archive Reel 214, Frames 83007, 83154, 83163 respectively.

57. Inomata Keitarō, "Aru yokusan senkyo no kiroku" (One Yokusan Election's Record), Nihon rekishi, 163 (January 1962), 79-83. On November 18, 1941 the affair reached the Diet floor when Tōhōkai representative Mitamura Takeo (1899-1964) interpellated Tojo about allegations of interference in the Nagasaki election. See Dai 77-kai teikoku gikai shügïn giin iinkaigiroku, dai 1 rui dai 1 gō yosan iinkaigiroku dai 3 kai-Shöwa 16-nen 11-gatsu 19-nichi, 45-46.

58. "Senkyo mukō," Reel 214, Frame 84023.

59. "Kakujin betsu," Reel 214, Frame 84120.

60. Ibid., 84119-84120 and Jōhōka, "Senkyo kanshō mondai bekki 5, Fu ken chiji ni taisuru senkyo jizai ra no kokuso kokuhatsu shirabe" (Appendix E: Investigations of Accusations and Indictments against Prefectural Governors for Criminal Incidents in the Election), Top Secret August 20, 1942 Reel 215, Frame 84158.

61. "Fu ken chiji," Frame 84158. Emphasis in original.

62. Ibid., Frame 84116.

63. Naimushō keihōkyoku keimuka, "Senkyo kankeisha kokuso kokuhatsu jiken shirabe" (Investigations of Accusations and Indictments of Election Related Individuals), Secret June 10, 1942 in $J R 44$ Reel 44, Frame 0148.

64. Noyori Hideuchi, "Watakushi wa naze ni sōsenkyo ni yabareta ka" (Why Was I Defeated in the General Election), June 1942 in Noyori, 135-136.

65. Ibid., 141-145.

66. Noyori Hideuchi, “Tojo naikaku wa masu jira han o shimeshite senkyo ni nozomu beshi" (The Tojo Cabinet Should Deal with the Election by First Personally Setting an Example), March 10, 1942 in Noyori, 108 and "Senkyo no jōhai," 113.

67. Hakkin nenpö, 4, 886, 897, 899, and 902.

68. "Kakujin betsu," Frame 84117-84118.

69. "Watakushi wa naze," 147.

70. Noyori Hideuchi, "Senkyo de jishin o akka saseru na" (Don't Let the Election Corrupt Human Nature), June 3, 1942 in Noyori, 110.

71. "Hōkokusho, 6," TNNS, April 19, 1942, 2; "Hokubo no kan," $H S$, April 19, 1942, 2 and "Tohoku no kan, ge," $H S$, April 19, 1942, 2.

72. Author's interview with the Honorable Miyake Shoichi M. P., March 25, 1977 in Tokyo. I am grateful to Professor Sodei Rinjirō for kindly arranging this valuab'e interview. "Senkyo hōkoku," TNNS, April 29, 1942, 4.

73. Miyake interview.

74. Miyake Shoichi, Ikusanaga o koete (Crossing Many Obstacles) (Tokyo: Kobunsha, 1966), 294-295.

75. Miyake interview.

76. "Senkyo mukō," Reel 215, Frame 84108 and Akita keisatsu buchō (Police Director Akita Prefecture), "Tokkō hihatsu dai 373 gō" (Thought Police Secret Report Number 373), Secret April 7, 1942 in Archive Reel 211, Frame 80017-80018.

77. "Senkyo mukō," Frame 84039-84041 and "Senkyo ihan," Frame 84049- 
84051, 84069; "Kakujin betsu," Frame 84107. Keihōkyoku keimuka, "Shūgiin giin senkyo ni kansuru soshō shirabe" (Investigations of Accusations in the Lower House Election), Secret June 16, 1942 in JR 44 Reel 44, Frame 0147. Also see Imai Seiichi, "Ōko shita rokotsu na kanshō-yokusan senkyo" (Blunt Interference That Swaggered: The Yokusan Election), Asahi jyānaru, 7:44 (October 24, 1965), 78-85.

78. Shimomura Eiji, "Yokusan senkyo wa mukō! Jiyū o mamotta aru hanketsu" (The Yokusan Election is Invalid! One Verdict that Defended Liberty), in Tokyo 12 chiyanneru hōbōbu, eds., Shogen watakushi no Shōwashi, 3, Taiheiyo sensō zenki (Testimony of Personal Showa History, 3, The Initial Stage of the Pacific War) (Tokyo: Gakugei shorin, 1969), 210.

79. Yoshida Hisashi, "Aru hanketsukan no kiroku" (The Record of One Judicial Verdict), Hōgaku semina, 41 (August 1959), 58. Yoshida Hisashi (1899. ) was the presiding judge who handed down the verdict.

80. Imai, "Ōko," 81-82.

81. Soma, 55-60 and NMSS, 2, 351-352, 810-815.

82. Soma, 76-78 and NMSS, $1,312$.

83. Soma, $128-130$ and NMSS, 1, 379-380.

84. $T A S$, February 11, 1928, evening ed., 2.

85. Hatoyama Ichirō, Hatoyama Ichirō kaikoroku (Hatoyama Ichiro's Memoirs) (Tokyo: Bungei shunjū, 1957), 16.

86. Andō Masazumi, Kōwa o mae ni shite (Prior Lecturing) (Tokyo: Keizai oraisha, 1951), 118-119.

87. Saitō Takao, Kaikoron 70-nen (Reminiscences of 70 Years) (Tokyo: Minsei shoin, 1948), 132-133.

88. RG 331, SCAP, IPS Case \#358 The Imperial Rule Assistance Association Exhibit \#17 "Interrogration of Ashida Hitoshi," March 20, 1947, 1-3 and $T A S$, May 19, 1942, 2.

\section{Chapter Seven}

1. Kiroku, 374, 378. Kōmei senkyo renmei, eds., Shūgiin giin senkyo no jisseki dai 1-kai-dai-30-kai (Results of Elections of Representatives to the Lower House: First through Thirtieth Elections) (Tokyo: Kōmei senkyo renmei, 1967), 43, 73.

2. Kiroku, 379-380.

3. "Konji shūgiin," SG (May 1942), 1-25.

4. Shügiin jisseki, 164.

5. Kiyose Ichirō, "Seiji taisei no sasshin o nozomu" (Hopes for a Political Order Renovation), Kokusaku kenkyükai shühō, 19:4 Part 2 (May 8, 1942), 1.

6. Advertiser, May 1, 1942, evening ed., 1-1.

7. Arai Tatsuo, "Sōsenkyo o kaerimite" (Looking Back on the General Election), Ekonomisuto, 20:18 (May 13, 1942), 16. On the so-called "coercion theory" of voting see $T S, 4,210$ and Hayashi, 308 for descriptions of the "voter hunt."

8. A sample form used in Tokyo Prefecture is available at the Shisei kaikan as "Shōwa 17-nen 4-gatsu 30-nichi shikō shūgiin giin sōsenkyo shiryō" (Documents of the Lower House General Election Held April 30, 1942), Document \#13.

9. Naimushō chihōkyoku shinkōka, "Kaku dō-fu-ken ni okeru yokusan senkyo kantetsu undō no seika, 1,"Shimin, 37:7 (July 1942), 39. 
10. These editorials are cited in full in NCS, 228-233. For excerpted press comments of the major Japanese newspapers see Advertiser, May 2, 1942, 2-2.

11. Kiroku, 319-320 and 421-428.

12. Tojo Hideki, "Sōsenkyo o owarite" (The Election is Over), May 2, 1942 in Naikaku jōhōkyoku, ed., Daitōa sensō ni kansuru no sūkō (National Policy Trends Towards the Greater East Asia War) (Tokyo: Naikaku insatsukyoku, 1942), 89-90.

13. Senkyo jisseki, 168 .

14. "Kyū Shakai taishūtō kei," Archive Reel 214, Frame 83861-83863. 60-86.

15. "Kokkashugi dantai," $J R$ 44, Frame 0029-0037. Cf., TG (April 1942),

16. Shinmei Masamichi, "Konji sōsenkyo ni tsuite no hihan" (Criticism of This General Election), Toshi mondai, 34:6 (June 1, 1942), 1-3.

17. "Jikyoku kensetsu tōben" (Constructive Answers [to Questions About] the Current Situation), Köron (May 1942), 179. Also see Shimizu, Kokumin undō, 154.

18. Shimizu, Kokumin undō, 176.

19. See Kido nikki, 2, 958-960. Diary entries for 27 through 29 April 1942. On May 1, Kido reported these discussions to the emperor. Earlier, while electioneering in Niigata, General Abe had remarked that it was natural to establish a new political party based on elected, recommended candidates, but that the exact details had yet to be worked out. TAS, April 22, 1942, 1.

20. Yokogoshi, 2, 53.

21. For details see Yokusan seijikai, ed., Yokusan seijikai no kessei made (To the Yokusan Political Society's Formation) (Tokyo: Yokusan seijikai, 1942), 1-10. I am grateful to Mr. Hashimoto Seinosuke for providing me with a copy of this document. Also see YKUS, 452-461.

22. Abe Nobuyuki, "Yokusan seijikai no konpon seishin" (The Yokusan Political Society's Fundamental Spirit), May 20, 1942 in Kessei made, 3.

23. Ibid., 1 .

24. Among the ten non-joiners, six were under indictment for alleged election law violations. Two others, Ozaki Yukio for alleged lese majeste and Inukai Takeru (1896-1960) for alleged implication in the Richard Sorge spy ring, were also under indictment. The two remaining Diet men unaccountably were not invited to join the Political Society. Learning of its oversight, the Society quickly remedied it.

25. Yokogoshi, 2, 59.

26. Cf., the actual Political Society's organization and aims with that proposed in the previously cited Yokudo plan appearing in Kokusaku kenkyükai shühō, 6-7.

27. Yokogoshi, 2, 58-59.

28. 1943 Asahi nenkan, 119 and Dōmei tsushinsha, eds., Shōwa jūhachinen Dōmei jïi nenkan (Dōmei Current Events Yearbook, 1943 Edition) (Tokyo: Dōmei tsushinsha, 1942), 85.

29. Mainichi shimbunsha, eds., Shōwa jüshichinen Mainichi nenkan (Tokyo: Nichi Nichi shimbunsha, 1942), 111.

30. Naikaku kanbō shuji, "Kakuko dai 157 gō (rinji gikai shōshū no ken)" (Cabinet Directive Number 157 [Opinions on the Calling of an Extraordinary Diet Session]), Secret May 4, 1942 in KKS, File 2A 12 rui 2547 Document \#30.

31. "Yokusan seijikai no kessei narabini Taisei yokusankai no kaigumi oyobi kakusho iin setsuichi ni kansuru ikō" (Opinions Concerning the Formation of 
the Yokusan Political Society as well as the IRAA's Reorganization and the Establishment of Various Ministerial Subcommittees), Top Secret n.d., but clearly produced after May 20, 1942, apparently by the Keihōkyoku hōanka. JR 44, Frame 0081. Unfortunately, this intriguing document is incomplete.

32. "Saikin seiji jōsei," IR 44, Frame 0112-0113.

33. "Yokusan seijikai . . . kansuru ikō," Frame 0081.

34. "Kokkashugi undō," Frame 0007-0008. For a sampling of reform rightist anti-Political Society vehemence see Senzen, 4, 794-806. So great was resentment that even Director Abe's life was threatened.

35. "Saikin seiji jōsei," 0114.

36. Senzen, 4, 793 and YKUS, 458.

37. Yokogoshi, 2, 60-63.

38. TS, 4, 215 and Endō, 29-30.

39. TS, 4, 214-215.

40. Endō, 29. Statistics cited in Ishida, 51.

41. Mainichi shimbunsha, ed., Shōwa jükunen Mainichi nenkan (1944 Mainichi Yearbook) (Tokyo: Mainichi shimbunsha, 1943), 44.

42. "Sōnendan no yuki beki michi" (The Road the Adults Association Should Travel), TAS, April 15, 1942, 1 and "Yokusō hatsudō bunseki" (An Analysis of Adults Association Activity), Mainichi shimbun, March 4, 1943 cited in YKUS, 909-910. The Nichi Nichi shimbun changed its name to Mainichi shimbun on January 1, 1943.

43. "Kessen taisei o chihō ni miru, 1" (The Decisive Battle's Order Seen Regionally), TAS, March 21, 1943, 1. On the estrangement between the Adults Association and the IRAA see Keichishō jōhōka, "Jimu seiseki Shōwa 18-nen 4-gatsu 22-nichi itaru Shōwa 19-nen 7-gatsu 25-nichi," in Archive Title 1527 Reel 225, Frame 97326.

44. Taisei yokusankai, ed., Dai 3 kai chūō kyōryoku kaigi sōjōkai kaigiroku (Minutes of the Third Central Cooperative Committee General Meeting), Secret September 26-29, 1942 (Tokyo: Taisei yokusankai, 1942), 346-349.

45. Yokogoshi, 2, 64. Also see Dōmei Tsushinsha, ed., Shōwa jükunen Dōmei jiji nenkan (Tokyo: Dōmei tsushinsha, 1943), 72.

46. See Keishichō jōhōka, "Dai 81 kai teikoku gikai shomondai" (Various Problems of the 81st Imperial Diet), Top Secret December 1942 in JR 44 Title 3:21 Dai 81 kai teikoku gikai shomondai, Reel 44, Frame 0004-0005.

47. Ibid., Frame 0004 .

48. Ibid., Frame 0005 .

49. Concerning the formation and the aims of these largely overlooked post-election Diet clubs see, "Dai 81 kai," Frame 0007 and 0009-0017. The latter is a police analysis of these "research groups," their leaders and their parliamentary goals. Also refer to TG (May 1942), 42; Yokogoshi, 2, 64; Ishida, 42; and Nihon seiji kenkyūshitsu hensan, edc. Shōwa jūhachinen doka kihan Nihon seiji nenpō dai 3 gō (Japan Political Yearbook for 1943 Part 3) (Tokyo: Shōwa kankōkai, 1943), 239. Membership lists are available in "Dai 81 kai" appendix compiled by Keishichō jōhōka, "Shōwa 17-nen 12-gatsu 21-nichi genzai shūgiin kaku shozoku giin meikan" (A Directory of Various Affiliations of Representatives in the Lower House as of December 21, 1942), Frame 0026-0036.

50. Yokogoshi, 2, 65. Political Society branches were finally established in June 1943.

51. "Yokusei innai soshiki to seyo" (Let's Have the Political Society as an 
In-House Organization), $T A S$, March 31, 1943, 2. Also refer to 1943 Seiji nenpō, 256 for an excerpt of this editorial and a critical commentary on it.

52. Kanpō gōgai-Shōwa 18-nen 2-gatsu 4-ka Dai 80-81 kai teikoku gikai kizokuin giji sokkiroku dai 5 go (Official Gazette: Proceedings of the Plenary Sessions of the 80th and 81st Sessions of the Imperial Diet's House of Peers for February 4, 1943 Fifth Session), 91-97.

53. Dai 81 kai teikoku gikai shügiin gïn iinkaigiroku, dai 1 rui dai 1 gō yosan iinkai giroku dai 10 kai-Showwa 18-nen 2-gatsu 6-nichi (Proceedings of the Committee Sessions of the 81st Imperial Diet Lower House, First Series First Number Minutes of the Budget Committee Tenth Session for February 6, 1943), 195-203.

54. See the heated exchanges in Dai 81-kai teikoku gikai shügiin giin iinkaigiroku, dai 6 rui dai 5 gō shisei chukai hōritsuan gai yon hen iinkaigiroku dai 10 kai-Shōwa 18-nen 2-gatsu 18-nichi (Sixth Series Fifth Number Committee for the Consideration of the Legal Draft for City Reorganization and Four Other Matters Tenth Session for February 18, 1943), 203-220.

55. Ibid., Dai 11 kai Shöwa 18-nen 2-gatsu 19-nichi (Eleventh Session for February 19, 1943), 223-224.

56. Senzen, 4, 907 and TG (March 1943), 20-25.

57. Endō, 31-32. YKUS, 916. Nihon seiji kenkyūshitsu hensan, eds., Shōwa jühachinen doka kihan Nihon seiji nenpō dai 3 gō (Japan Political Yearbook for 1943 Part 3) (Tokyo: Shōwa kankōkai, 1943), 135-141.

58. Senzen, 4, 911; TG (March 1943), 25; and Hayashi, 329.

59. See Nakatani, 147-150 for a description of these tumultuous events.

60. Senzen, 4, 937-941 details this event.

61. Otani, Kempeishi, 447-448.

62. Maeda den, 404-405 and Nakatani, 182-183. For the cabinet minutes on the Nakano case see Inaba Masao, "Inaba Masao no 'Nakano jiken' ni kansuru kiroku" (Inaba's Record about the Nakano Incident), in Tōjō Hideki kankōkai, eds., Tōjō Hideki (Tokyo: Fūyō shobō, 1974), 592-598. On the Nakano Incident see Kondō Masao, "Kempei seiji' to Nakano Seigō jiken" (Government by the Military Police and the Nankano Seigō Incident), Gunji kenkyü, 8:4 (March 1973), 99-107.

63. The interpretation that a one-nation one-party system did result is offered in $T S, 4,210-211$.

64. Maruyama Masao, Thought and Behavior in Modern Japanese Politics (London: Cambridge University Press, 1963), 74, maintains the Japanese right began to criticize Tojo when the war turned against Japan. This is not, as Professor Maruyama observes, to suggest or even to intimate that persons like Akao Bin were "democrats" or were somehow transformed into "democrats" by defying Tojo.

65. Satō, Shogen, 375.

66. A. L. Unger, The Totalitarian Party (London: Cambridge U. Press, 1974), 5.

67. I use the term "pluralistic" to avoid the "authoritarian" label which, as applied to modern Japanese history, connotes the so-called "authoritarian modernization thesis," namely that rapid modernization created severe social and economic dislocations that led the government to pursue repressive policies at home and aggressive expansion abroad. See George M. Wilson, "A New Look at the Problem of Japanese Fascism," Comparative Studies in Society and History, 10:4 (July 1968), 404. 
68. The Suzuki Kantarō cabinet established the Kokumin giyütai on June 9, 1945. The giyutai dissolved August 15 that same year. Its purpose was to mobilize the population for increased military and production efforts. Males between 16 and 61 and females between 17 and 41 were to be organized in each administrative locality. They were also considered a national militia in reserve and designated national combatants (kokumin sentōtai).

69. See Nakamura, Tennōsei, 13 for amplification of this point.

70. Although war-time Japan was a semi-free society, with rare exceptions, the secret, i.e., free, ballot was honored during the 1942 general election and the subsequent regional wartime elections.

71. On Nazi block leaders' roles see Unger, 99-104. The Soviet agitator became institutionalized for the 1937 Soviet elections when agitpunkty (agitation points) appeared in each polling district of the USSR. These were, however, political associations and led by the local party organization. Unger, 127.

72. This is not to deny that the Home Ministry or the Military Affairs Bureau may have desired a more highly politicized, more rigidly controlled neighborhood association network.

73. Otani, Kempeishi, 451.

74. See Wilson, "Japan Fascism," 412. Also refer to Itō Takashi, "Nihon seijishi kenkyū e no isshi-kaku" (Towards an Impartial Approach to the Study of Japanese Political History), Shisō, 624 (June 1976), 215-228 for an excellent critic of the indiscriminate manner in which the term "fascism" has been applied to wartime Japan. 



\title{
Appendix A
}

\author{
The Outline of the Basic Campaign for the \\ Accomplishment of the Yokusan Election
}

Cabinet Resolution February 18, 1942

1) The Title of the Campaign: It will be called The Campaign for the Accomplishment of the Election for the Successful Prosecution of the Greater East Asia War.

2) The Campaign's Objectives: At the time the general election is executed, a mass, national, people's movement will be developed in order to anticipate the establishment of a fresh, powerful Diet which has the aim of successful prosecution of the Greater East Asia War. We anticipate that the realization of a yokusan election will cope with the serious situation.

3) Basic Campaign Policy: The election serves as an opportunity to raise national morale for inevitable victory and to harden the firm national consciousness for the prosecution of the Greater East Asia War. The establishment of a fresh, powerful Diet can positively evoke a heightened national, earnest, pure, political will.

The prosecution of the Greater East Asia War is the major objective, and we can foment universally the opportunity to mobilize for the Diet suitable, qualified men who should be entrusted with the serious responsibility of true imperial rule assistance.

Faced with the serious circumstances under which the election takes place, the election will be completely ethical and will decisively sweep away existing evil practices so that a just, clean election can appear.

4) Methods for Executing the Election: It will be thoroughly inculcated by an enlightenment campaign.

Based on the above fundamental principles, this campaign, as a great enlightenment movement having the aims of successful prosecution of the Greater East Asia War, establishment of a yokusan Diet, and the realization of a yokusan election, will mobilize the buraku, chonai-kai, and tonarigumi in cities, towns, and villages, local organizations, and, of course, all other possible organizations. We anticipate active development.

Fomenting the tendency to recommend candidates: It can positively foment the tendency to recommend the most suitable candidates for the realization of the yokusan election's enlightenment campaign.

Election Ethics and Wartime Arrangements: During a time of grave crisis, in order to have a true and sincere yokusan election, we expect the following arrangements will anticipate election ethics and wartime arrangements:

We expect a just election to sweep away existing private considerations and connections related to elections.

We will endeavor to arouse the mass electorate's self-consciousness, work for the eradication of election crimes, and prevent voter absenteeism. As for election campaigners, through their self-discipline and self-regulation, we expect that election violations will cease.

In compliance with wartime requirements, we will work rationally to provide 
materials and labor. Economy and improved campaign methods are necessary for the election campaign.

Organs for the implementation of the campaign: This campaign, as a campaign to unite government and people in national solidarity, will be implemented by the principal organs indicated below.

The government will determine basic campaign policy and will lead the entire campaign under close contact with related organs.

Local governments, complying with the national government's basic policy, will determine campaign implementation policy and lead the entire campaign locally.

The Imperial Rule Assistance Association (including the Imperial Rule Assistance Young Adults Association) and the Central Election Purification League will develop a popular movement in cooperation with the national and local governments.

Source: Naikaku kanbō shuji, ed. (Chief Cabinet Secretariat), Naikaku seido 70-nen shi (A Seventy Year History of the Cabinet System) (Tokyo: Okurashō insatsu kyoku, 1955), pp. 490-491. I am grateful to Mr. Suekuni Masao of the Böeicho senshi shitsu for providing me with a copy of this document.

\section{Appendix B}

Articles to be Especially Alert for at This Time Cabinet Information Bureau Second Section December 9, 1941

1) Explanations distorting the war's true motives or slandering the Empire's just position.

2) Explanations distorting the particulars of the opening of hostilities or slandering measures of the government or high command.

3) Arguments whose tenor suggests that we expected German and Italian assistance at the time of opening the war.

4) Arguments whose tenor suggests that a conflict of opinions between the government and the military exists.

5) Explanations that the public should not obey government directions or that might cause a lack of harmony in public opinion.

6) Arguments whose tenor would likely bring about unrest and agitation in relations with China, Manchukuo, and in other foreign relations.

7) Arguments whose tone could foster anti-war or war-weariness tendencies among the public.

8) Arguments tending to foster anti-military ideas.

9) Arguments tending to foster pacifist tendencies which could cause a dejection of national morale.

10) All arguments whose tone might cause a disturbance of home front law and order.

Source: "Kiji sashi-tomeru jikō," cited in Hatanaka Shigeo, Shōwa shuppan danatsu shoshi (Tokyo: Tosho shimbun, 1977), 67-70. 


\section{Appendix C}

Matters Related to the Control of Articles about the General Election to the House of Representatives Secret February 28, 1942.

Matters such as the following which oppose this general election or intentionally try to diminish national zeal toward the general election:

A) 1. Describing the election as originating in democratic ideas that are contrary to our national polity or trying to destroy national polity will not be approved.

2. As for the execution of a general election in wartime, matters likely to divide public opinion, divulge our deficiencies to the enemy, actions that waste wartime materials, hinder expansion of production, emphasize an adverse influence on the prosecution of the Holy War, or points about bossism will not be allowed.

3. Persons claiming that without electoral reform old-order politicians inevitably will use the e'ection to regain their former high positions, and, consequently, the election is meaningless.

B) Matters that might give birth to ideas critical of the Political Council, intentionally distort the government's purposes, create distrust of the government, or suspicion about the election's fairness. Examples:

1. Independent candidates have been pressured as part of a plan to elect specific individuals, and, thus, it is a denial of the spirit of the constitution. 2. The Political Council, government, military, or government officials, in order to accomplish their own political ambitions, have created a plan for a government manufactured election, and the candidate recommendation system is an obstruction to a fair election.

3. Extensive slander of the men the government summoned at the time of establishing the Political Council or suggesting, as a method, the establishment of the Political Council was a backward step.

C) Matters such as agitating to show disapproval (in the election) by not voting or voiding one's ballot.

D) Matters such as agitating that, because this election will establish a yokusan political order, one should absolutely prevent the return to high positions of old-order politicians either by illegal means or direct action.

E) Matters such as taking advantage of the election to agitate the public with enemy or communist propaganda.

F) Other matters likely to obstruct public order will not be allowed.

Source: Naimushō keihōkyokuchō, "Shūgiin giin sōsenkyo ni kansuru kiji torishimari ni kansuru ken," Secret February 28, 1942 in Archive Title 1470 Reel 214, Frame 83420-83421.

\section{Appendix D}

Police Bureau Instruction Number 14 Top Secret March 26, 1942

FROM: Home Ministry Police Bureau Director

TO: $\quad$ Each Prefectural Governor

Superintendent of the Metropolitan Police Board 
As for election campaign speech rallies in this election for the Lower House held under Greater East Asia Wartime conditions, facing the necessity of unifying still more public opinion and demonstrating the true value of one hundred million people's total order, together with anticipating especially appropriate guidance and management, on the one hand these campaign rallies, as a part of the imperial rule assistance movement, will positively elevate national morale. In general, the following directions are expected to be used to control campaign rallies.

1) These standards of control and guidance should be pointed out to candidates or election campaign directors. It is desired that you adopt methods to deliver adequately these objectives.

2) It is desired that you thoroughly anticipate and correct by guidance before the fact serious points concerning matters which could result in cautions or suspensions.

3) As for matters in election rallies which are recognizable as requiring special attention, whenever such arguments occur they are to be reported simultaneously to the Justice Ministry's Chief of Criminal Affairs and the Chief Justice of the Court, both of whom shou'd be properly notified.

\section{Part I Standards Subject to Control at Speech Rally Arguments}

A) Related to the Greater East Asia War

1) Fomenting a peace movement or optimistic attitude or doing such things which might give rise to fears having an adverse influence on national determination to prosecute a long war.

2) Arbitrarily calling for the restoration of various Southern Front territories, spreading one's own personal view about the Southern Areas administrative methods and economic policies, of such matters likely to create fears and confusion about the government's Greater East Asia statesmanship.

3) Matters such as calling the Greater East Asia War a racial war between the colored and whites.

4) Creating doubts in public confidence in the national government or its ability, or maintaining that there should be direct negotiations with Chiang's (kai-shek) political clique.

B) Related to Foreign Affairs

1) Anything that might hinder the friendly relations with Germany, Italy, or other Axis powers.

2) Maintaining that hostilities should be opened against the Soviet Union, emphasizing the opinion about the danger on the Northern Front, or otherwise giving the impression that our nation will attack the Soviet Union, or needlessly irritating the Soviet Union.

C) Domestic Problems

1) Intentionally abusively criticizing the government or its policies giving rise to fears of government insincerity.

2) Arbitrarily denouncing or abusing the nation's upper classes and such things as encouraging domestic rivalry.

3) Of course, matters that might range into anti-war or anti-military statements; intentionally attacking government officials or such things that might give rise to a split between the government and the public or cause an antigovernment atmosphere are forbidden.

4) Discussing material shortages, stimulating disagreement over material 
supply and demand, irritating by exaggeration about the handling of public discontent and dissatisfaction, or matters related to insinuating the existence of scandalous incidents which might foment societal unrest.

5) Opposition to economic controls, falsifying those controls' true motives, or matters which might give rise to adverse ideas about economic controls.

6) Suggesting inflation's inevitability or matters that might provoke concern about financial monetary policy.

7) Speculating about how quickly surplus Southern Front resources will flow into (Japan), predicting relief from economic controls, the change or closing of medium and small industries, and other matters, like the adverse influence exerted by reorganization.

D) Election Related

1) Opposing this general election or causing a lessening of national zeal toward the general election.

2) Intentionally distorting the government's true motives concerning the recommendation body, the Political Council, causing a lack of confidence in the government, or giving birth to suspicions about the election's fairness.

E) Matters such as being the source of false, wild rumors about the present situation.

F) Matters such as ranging into military, diplomatic, or economic state secrets.

\section{Part II Outline for Positive Guidance of Speeches}

Per the instructions for positive guidance which were previously indicated, according to the government's methods of leading public opinion, thoroughly plan special guidance which emphasizes above all else the following points:

1) Based on the Imperial Rescript of the Declaration of War, endeavor to clarify the justice (of our position) and righteousness of opening hostilities.

2) Emphasize that after we patiently had endeavored for peace over a long period, finally, for the sake of the Empire's prestige and the defense of our national existence in Greater East Asia, when it was unavoidable, we went to war to destroy wickedness and establish righteousness. If we are unable to win this war, the Empire's survival and lasting independence as well as the equilibrium of East Asia cannot be expected.

3 ) No matter how long this war lasts, we will eradicate the evil roots of American and British military and economic pressure. You should emphasize the determination inevitably to realize the great ideal of the Land of the Gods.

4) As for the issue of total war, stimu'ate the determination to apply oneself with untiring perseverance to practice patriotic public service at one's occupation with the awareness of total war.

5) This war will certainly be protracted. Together with hardening all the more national resolution and the belief in inevitable victory, you should plan to elevate national morale.

6) The enemy's will to fight will not necessarily collapse. It is necessary, once again, to prepare thoroughly for the expansion of enemy military preparations and their plans for another attempt at a decisive battle. Emphasize that the people should exert themselves for a vast increase in national production to demonstrate all the more national power.

7) Telling (your audiences) of our officers and men overseas bravely dying for their country, emphasize that we should do our duty in plans for increased 
agricultural production in wartime, reorganization of industry, national bond drives, and, towards important points of national policy, all the more sincerely perform our homefront public service.

Source: Naimushō keihōkyokuchō, "Keihōkyoku hakkō dai 14 gō," Top Secret March 1942 in Archive Title 1504 Reel 221, Frame 93218-93221. 


\section{General Glossary}

ankoku seiji 暗国政治

Asahi shimbun 朝日新闲

bakufu 幕府

bōhanka 防扢課

Bungei shunjū 文去合秋

bunkajin 大化人

burakukai 部落会

Chian keisatsuhō 治安警察法

Chihō chōkan kaigi 此长官会钱

Chihōkyoku 地方局

chōnaikai 町内会

Chūō kōron 中央公敦

Chūō kurabu中央偩然部

Chūō tei ha 中央亭玆

Dai ichi hikaeshitsu 第一控室

Dai ni issekikai 芽二一夕会

Dai Nippon fujinkai 大日本媂人会

Dai Nippon kōa dōmei 大棟哭画同盟

Dai Nippon seijikai 大日本政治会

Dai Nippon seinentō 大日本青年党

Dai Nippon Sekiseikai 大晰东誠会

Dai Nippontō 大日本党

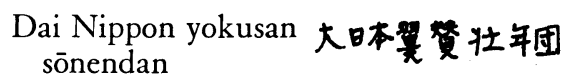

Daitōa dōshikai 大東亚同志会

Daitōa kensetsu
kyōkai police state

Asahi Newspaper

curtain government

Crimes Prevention Section

Bungei Shunju (magazine)

man of culture

village associations

Police Security Law

Prefectural Governors

Conference

Regional Affairs Bureau

ward association

Central Review (magazine)

Central Club

Central Restaurant Faction

First Lobby

Second One Evening Society

Great Japan Women's Association

Great Japan Revive Asia League

Great Japan Political Society

Great Japan Youth Party

Great Japan Sincerity Association

Great Japan Party

Great Japan Yokusan Young Adults Association

Great East Asia Comrades Society

Council to Eastablish Greater East Asia 


\section{Daitōa sensō 大象互壿争

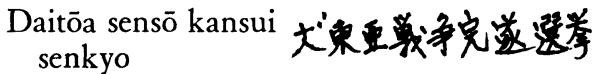

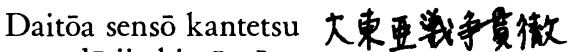 undō jisshi yōryō 遇動实狏要领}

dan

\section{dōinka 動员諟}

Dōjin kurabu 同人偩舁部

Dōkōkai 同交会

Ekonomisutoエコノミスト

enzetsukai 演哾会

Futabakai 二策会

Gendai 现代

genronsha 言論社

Genron shidō yōryō 言論指得要领

Genyōsha 玄洋社

Giin kurabu 謨员偩臬部

gun 尹尹阝 $^{\circ}$

gunjika 是事課

gunmuka 审初锞

gunmukyoku 审枒局

Hisuisen yūshi
daigishikai

hōanka 保实䛞

Hōchi shimbun 報知新闻

ichi hata gumi 一方买組

Ikken kinnō undō一野勤皇足動

Innai daigishikai 院内计鼓士会

Issekikai - 7 会

ishin 维新

jiban 地然
Greater East Asia War

Election to Accomplish the Greater East Asia War

Campaign Outline for Practical Accomplishment of Greater East Asia War

association

mobilization section

Comrades Club

Fraternity Association

The Economist (magazine)

speech rally

Double Leaf Society

Gendai (magazine)

opinion makers

Outline for Guiding Public Opinion

Dark Ocean Society

Parliamentarians Club

county

Military Section

Military Affairs Section

Military Affairs Bureau

Unrecommended Volunteer Dietmen's Society

Peace Preservation Section

Hōchi Newspaper

one flag groups

One Prefecture Loyalist Movement

In-House Parliamentarian's Society

One Evening Society

renovation

electoral base 
Jikishin dōjō 遖心道場

jissen-bu 実践部

Jiyutō 自由党

jōhōka 情報課

jōhōkyoku 情報局

Junsei senkyo kisei 稣正邆举规正坊㰻会 kyōgikai

Kaizō 改造

kanjōhō 官情報

Kanpō gōgai 官報号外

kansei gikai 官製漾会

kansen 官退

kazokushugi 家族主厷

Keibōdan 慗防团

Keihōkyoku 警保局

keimō 管蒙

Keimuka 警敄課

Keishichō 整視庁

Keizai giin renmei 经㳻㦈員連盟

Kenetsuka 梌阅誈

Kenkokukai 建国会

kimitsukin 機密金

Kinnō makoto 助里むととたすび社 musubisha

Kizokuin 巷族员

Kōa domei 舆画同盟

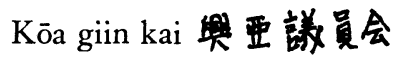

kōdō-ha 皇道淡

Kōdō yokusan
seinen renmei
Sincerity School

Practical Action Department

Liberty Party

Intelligence Section

Information Bureau

Council to Create a Clean Election

Reconstruction (magazine)

Secretariat Intelligence Report

Official Gazette

Government created Diet

Government controlled election

familialism

Coastal Defense Units

Police Bureau

enlightenment

Police Affairs Section

Metropolitan Police Headquarters

Economic Representatives League

Censorate

National Founding Society

secret fund

Sincere Loyalist Association

House of Peers

Revive Asia League

Revive Asia Dietmen's

Association

Imperial Way Faction

Imperial Way Imperial Rule Assistance Youth League 
kōhō 公晘

kokubō kokka 国防国家

Kokuhonsha 国本社

Kokumin dōmei 国民同盟

Kokumin giyūtai 国民差荿隊

Kokumin chūō renmei 国民中央連盟

Kokumin seishin sōdōin 国民精神统動員

Kokumin sentō-tai 国民尊窟陵

Kokumin shimbun 国民新闻

Kokuryūkai 黑竞会

Kokusai hankyō renmei 国際反芙連昷

Kokusaku kantetsu 国策贯微同盟
dōmei

Kokusaku kenkyūkai 国策研究会

Kokusui taishūtō 国料大象觉

kokutai 国体

Kōron 公論

Kōtō keisatsu 高等警禁

machiai 待合

Mainichi shimbun 每日新闲

meibōka 名望家

Minseitō 民政党

minsen 民逐

Miyako shimbun 都䉼闻

Mizuhō kurabu 瑞楉传架部

Naikaku kikakuin 内肉企两院，

Naikaku kanbō shuji 内闲官房主

Naimushō 内敢者

Nichi Nichi Shimbun 日日新用 official announcement of candidacy

National Defense State

National Foundation Society

Nationalist League

People's Heroic Fighting Corps

Nationalist Central League

National Spiritual General Mobilization

National Militia

Kokumin Newspaper

Black Dragon Society

International Anti-Communist League

League for Accomplishment of National Policy

National Policy Research Association

National Essence Mass Party

national essence

Koron (magazine)

Secret Police

meeting place

Mainichi Newspaper

men of influence

Constitutional Democratic Party

popular election

Miyako Newspaper

Japan Club

Cabinet Planning Board

Cabinet Secretariat Manager

Home Ministry

Nichi Nichi Newspaper 
Nippon Hyōron 日本訣論

Nippon keizai renmei 日本经㳻速显

Nippon shimbun renmei 日本新闻连显

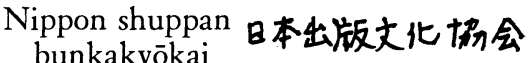

Nōgyō hōkoku renmei 费来報国速盟

Nōson keizai kōsei undō

\section{農村経济更生蚍動}

Rikken dōshikai 立蜜同至会

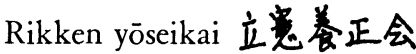

rokushakai 六社会

sangyō kumiai 座菜组合

Sanjūnichi kurabu 三ナ日㑭策部

seijikakari 政治係

Seishin kurabu 清新俔祭部

Seiyūkai 政友会

Senkyo shukusei 邆挙雨正通峌
undō

Shakai taishūtō 社会大鬼党

shinkō-ka 振舆課

Shisō geppō思想月報

shōgun 将軍

shoki shitsu 言敦空

Shōwa-kai 昭㕲会

Shōwa kenkyūkai 昭和研究会

shūgiin 核部院

Shūhō 速報

sōgō zasshi 紛合椎誌

sōnendan 壮年团

Sōsenkyo taisaku 鲔慰举奶策

aikokudantai kyōgikai 爱国団体協端会
Japan Critic (magazine)

Japan Economic Federation

Japan Newspaper Federation

Japan Publishers Cultural Association

Patriotic Agrarian League

Agrarian Villages Economic Rehabilitation Campaign.

Constitutional Comrades Association

Society for Cultivation of Constitutional Justice

Six Companies Council

industrial unions

30th Day Club

political office

New (Diet Members) Club

Constitutional Society of Friends

Election Purification Campaign

Socialist Masses Party

(Regional) Promotion Branch

Ideological Monthly

military commander and chief

secretariat

Showa Society

Showa Research Society

Diet Lower House

Shūhō (magazine)

composite magazines

young adults associations

Patriotic Societies' Council for Election Countermeasures 
Taisei yokusankai 大政翼嗪会

Teikoku hoteru-ha 帝国ホテル派

Teikoku zaigō gunjinkai

帝国在䐚军人会

Tōa renmei kyōkai 東更連显咕訲㦈会

Tōa renmei dōshikai 東更速盟同太会

Tōdairiku 菒大陸

Tōhōkai 真方会

Tōhōdōshikai 東才同志会

Tokkō (Tokubetsu 特高(特别高等
kōtō keisatsu)

tonari-gumi 隣组

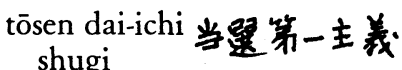

tōsui 統毁

uyoku 右巽

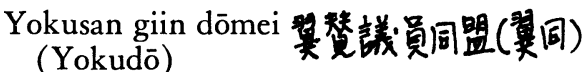

Yokusan seijikai 裂替政治会

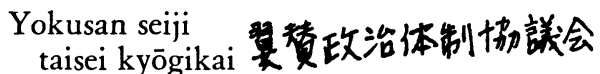

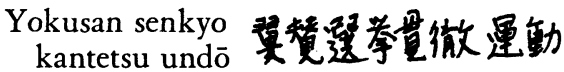

Yomiuri shimbun 読壳新用

yonshakai 四社会

yuryōkusha 有力者

Yūshi daigishikai 有志代嗉士会

zaibatsu 财肉

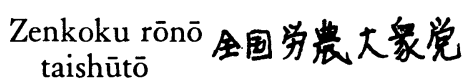

zentai sensō全体谈争
Imperial Rule Assistance Association

Imperial Hotel Faction

Imperial Reservists Association

East Asia League Cooperative Council

East Asia League Comrades Association

Eastern Continent (magazine)

Eastern Society

Eastern Society Comrades Association

Special Higher Police

neighborhood associations

election first philosophy

supreme command

right wing

Yokusan Dietmen's League

Yokusan Political Association

Yokusan Political Structure Cooperative Council

Campaign for Accomplishment of a Yokusan Election

Yomiuri Newspaper

Four Companies Council

men of influence

Volunteer Dietman's Association

financial cliques

National Labor Farmer Masses Party

Total war system 


\section{Glossary of Personal Names}

Abe Katsuo 阿部勝雄

Abe Nobuyuki 阿部信行

Adachi Kenzō 安毒遂葴

Akamatsu Katsumarō 赤松克魔

Akamatsu Sadao 赤松点堆

Akao Bin 赤民敏

Akinaga Tsukizō 秋永股

Akita Kiyoshi 秋田清

Amano Tatsuo 天野层夫

Andō Kisaburō 安蔯纪三郎

Andō Masazumi 安琵能

Araki Sadao 荒不是夫

Arima Yoriyasu 有馬頼案

Asanuma Inejirō浅沼槄次郎

Ashida Hitoshi 芦田均

Asō Hisashi 麻生久

Dōke Seiichirō 道家省一郎

Endō Ryūsaku 遠藤枊作

Etō Genkurō 江箱深九郎

Fujiwara Ginjirō 藤弹金民次郎

Fujiyama Aiichirō 费山受一郎

Fuke Toshiichi 福家俊一

Funada Naka 船田中

Furui Yoshimi 古升喜实

Gō Seinosuke 唧諴之助

Godō Takuo 五堂卓雄

Gotō Fumio 淩支夫

Gotō Ryūnosuke 嗦独隆之助

Hamada Kunimatsu浜田国松
Hamaguchi Osachi 浜口雄幸

Hara Sōbei 束椝兵街

Haraguchi Hatsutarō 保口初太郎

Hashida Kunihikō榙田邦彦

Hashimoto Seinosuke 椅本清之助

Hashimoto Kingorō 椅本欣五郎

Hatta Yoshiaki 八田嘉明

Hatoyama Ichirō 惚山一郎

Hayashi Senjūrō 林 铣十郎

Hazama Shigeru 俫闻成

Higashikuni Naruhikō 東久雨枪㢁

Hiraga Yuzura 平贺镶

Hirai Hachisaburō平 八三郎

Hiranuma Kiichirō 平沼䁬一郎

Hirota Kōki 应田弘媇

Homma Ken”ichiro 本问冕一郎

Honda Eisaku 本田英作

Honryō Shinjirō 本領信治郎

Hoshino Naoki 星野直榯

Ida Iwakusa 开田然楠

Ii Seiichi 开伊誠一

Ikeda Sumihisa 池田绝久

Ikemoto Jinshirō 池本甚四郎

Imai Hisashi 今井久

Imamaki Yoshio 今牧咅碓

Imamatsu Jirō 今松治郎

Ino Hiroya 开野硕鹤

Inukai Takeru 大美教

Inukai Tsuyoshi 大基揵 
Irogawa Taikichi 色川大吉

Ishiguro Tadaatsu 石黑忠菜

Ishiwara Kanji 石你党舀

Ishiwata Sōtarō 石淡䓑太郎

Iwabuchi Tatsuo 若消辰堆

Iwaguro Hideo 岩畔豪雄

Iwamura Michio 者村通世

Kamei Kan’ichirō 龟开一郎

Kanemitsu Tsuneo 金光席夫

Katō Hakujirō 加臀泊治郎

Katō Kanjū 加滕勘广

Katsu Masanori 勝正骞

Katsumata Seiichi 勝肉田清一

Kawai Eijirō 河合荣治郎

Kawamura Saburō 河村参郎

Kawasaki Katsu 川奇克

Kaya Okinori 贺屋嘼宣

Kazami Akira 周兄亲

Kido Kōichi 枦孝一

Kishi Nobusuke 岸琂介

Kita Reikichi 北 昤吉

Kiyosawa Kiyosei 清沢 洌

Kiyosei Ichirō 清瀨一郎

Kobayashi Ichizō 小林 一 三

Kobayashi Jun'ichirō 小林 順一郎

Kodama Hideo 棁王李雄

Kodama Yoshio 悓王誉士夫

Kogure Sanjirō 木桧三四郎

Koiso Kuniaki 小磯国昭

Konoe Atsumaro 近得等磨

Konoe Fumimaro 近撒文磨

Korematsu Jun’ichi 是松乷一
Koyama Makato 小山亮

Kuhara Funosuke 入賲房之助

Kumagai Ken’ichi 熊含密—

Kumagai Naota 熊后直太

Kuroda Iwao 黑田䈆

Machida Chūji 町田忠治

Maeda Yonezō 前田米藏

Maki Tatsuo 牧 達夫

Makino Ryōzō 牧野良三

Manabe Gijū 真金留 儀十

Manabe Katsu 傎金局养

Maruyama Tsurukichi 九山鶴吉

Matsuzaka Hiromasa 松阪宏政

Mazaki Katsuji 真崎勝次

Mazaki Jinsaburō真崎勘三郎

Mikami Takashi 三上卓

Miki Kumaji 三不熊二

Miki Takeo 三木武夫

Miki Yokichirō 三木与吉郎

Mitamura Nobuo 三田村武夫

Miwa Jyūsō 三軠寿㹤。

Miyake Shoichi 三宅 正一

Miyake Yajirō 沱八二郎

Miyazawa Taneo 宫沢能勇

Mizutani Chozaburō 水会长三郎

Murata Gorō 村田五郎

Mutō Akira 武蕂章

Nagai Ryūtarō 永开枊太郎

Nagata Tetsuzan 永田鉄山

Nakai Yotarō 中井良太郎

Nakajima Chikuhei 中员知久平

Nakamura Meijin 中村明人 
Nakamura Umekichi 中村梅吉

Nakano Seigō 中野正㣚

Nakatani Takeo 中吕武世

Narita Ichirō 成田一郎

Nishioka Takejirō西用竹次郎

Nomura Karoku野村袁六

Noyori Hideuchi 野依存市

Ōasa Tadao 大麻唯穷

Ōda Shigeru 芯田茂

Ogura Masatsune 小食正杬

Oikawa Koshirō 及川古郎

Ōishi Dai 大石大

Okada Tadahikō国田忠展

Ōkochi Kikō 大河内埋耕

Ōkochi Masatoshi 大河内正敏

Ōkubo Ryujirō 大久保留次郎

Ōkuma Shigenobu 大缋重信

Okumura Kiwao 奥村喜和男

Ōmori Issei 大来一声

Ōta Kōzō 太田粠造

Ōta Masataka 太田正恭

Ozaki Yukio 尾崎行堆

Pak Ch'un-kum 朴春兴

Rōyama Masamichi 山政道

Saionji Kinmochi 西国夺公望

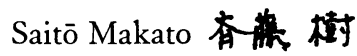

Saitō Takao 青窟 隆夫

Sakai Tadamasa 酒井忠正

Sakurai Hyōgorō 楼兵五衩

Sasagawa Ryōichi 镇川良一

Sasai Itsucho 佐々接一昆

Satō Kenryō 作楅了
Satsuma Yūji 壦府次

Sengoku Kotarō千石糸太部

Shiba Teikichi 斯被克告

Shikata Ryōji 四才誴二

Shimada Toshio 农田俊堆

Shimizu Moriaki 清水盛明

Shimomura Hiroshi 下村宏

Shimomura Jirō 下村 $=$ 郎

Shinagawa Yajirō 品川弥二郎

Shinoda Yasoya 侁田八十八

Shioden Nobutaka 四王天廷孝

Shiratori Toshio 白岛敏夫

Suematsu Kaiichirō 末松偕一郎

Suetsugu Nobumasa 来次信正

Susugida Yoshitomo 溥田美朝

Suzuki Kisaburō 鈴楼三部

Suzuki Teiichi 领顺一

Tagawa Daikichirō田川大吉郎

Takahashi Korekiyo 高松是请

Takahashi Sankichi 高榴三吉

Takami Yukimichi 高晃之通

Taki Masao 浙正碓

Tanabe Shichiroku田迅七六

Tanaka Sawaji 田中沢二

Tanaka Tokichi 田中都吉

Tanaka Tomogaku田中智学

Tani Masayuki 荅正之

Tawara Magoichi 俵秄一

Tazawa Yoshiharu 田沢莪俌

Tokutomi Sohō 猿富㨋一郎

Tōjō Hideki 東条英柲

Tomeoka Yukio 留闺幸男 
Tomita Kenji 䔰田建治

Tōyama Mitsuru 频山满

Toyoda Teijiro 些田点次郎。

Tsugumo Kunitoshi 津芸国利

Tsukada Osamu塚田 攻

Tsukui Tatsuo 津久井竞唯

Ushitsuka Toratarō 牛塚虎太部

Wakamiya Sadao 若宫点夫

Yabe Teiji 部克治

Yabuki Seizō 失吹尚三
Yagi Itsurō 八木逸

Yamazaki Iwao 山㥓屡

Yamazaki Tatsunosuke 山伢遠之輔

Yanegawa Heisuke 棑师平助

Yasui Eiji 安井英二

Yatsugi Kazuo 失次一夫

Yatsunami Takeji 八业治

Yokoyama Sukenari 模山勋成

Yūki Toyotarō结城裳太郎

Yuzawa Michio 晹沢三千男 


\section{Bibliography}

UnPublished Sources, Japanese Language

Gaimushō shiryōkan (Foreign Ministry of Japan Archives). Particularly:

Taisei yokusan undō kankei ikken. vols. 1 and 3. File A 500.4

Hashimoto Seinosuke. "Rengōkoku saikō shireikan • Dogurasu Makkāsā kaka." July 30, 1949. (Copy in possession of Professor Itō Takashi.)

Kokuritsu kōbun shokan (Japan National Archives). Particularly:

Chihō chōkan keisatsu buchō kaigi shorui, Shōwa 17-nen. File hen sei 3A 15-21-5.

Köbun ruishu dai 66 hen Shöwa 17 nen kan 13 Kanshoku mon (9), kansei (9) rikugunshō (1). File $2 \mathrm{~A} 12$ rui 2571.

Köbun ruishu dai 66 hen Shōwa 17 nen kan 1 Koshitsu mon · seikō mon (1) shōchoku hōrei · kyōtsuho · chihō jiji $\cdot$ teikoku gikai (1). File 2A 12 rui 2547.

Naikaku kanbō sōmuka shiryō Meiji 39-nen Shōwa 20-nen Taisei yokusan undō kiyaku sonota kitei . Tasei yokusan kankei shorui tsuzuri · tokushu shiryō - dai 1 rui · seiseki kankei. File 2A 40 shi 13.

Showa 16 nen 6 gatsu ika reiki tsuzuri. File hen sei 3A 15 48-3.

Showa 17 nen kōbun zassan, 87 kan. File 2A 15 san 2783.

Shōwa 17 nen 6 gatsu 16 nichi Saikin ni okeru kokkashugi undō no jōsei. File hen sei 6-7-1.

Shügiin giin senkyo ni kansuru soshō shirabe. File hen sei 3A 15 6-12-1.

Library of Congress, comp. Microfilm Japanese Rarities. Particularly:

Naimushō. keihōkyoku. hōanka. Seiji kankei shorui tsuzuri (1941-1942). Reel 44.

hōshin, August 1942. Reel 44.

gaiken), 1942. Reel 44.

Reel 44.

- Microfilm Orien Japan. Particularly:

Naimushō. Keihokyōku. hōanka. Chihō chōkan keisatsu buchō kaigi kankei shorui, 1942. Reel 38:3.

1933-1945. Reel 37:3.

- Microfilm Reproductions of Selected Archives of the Japanese Army, Navy, and Other Government Agencies, 1868-1945. Particularly:

Gaimushō. jōhōka. Senkyo ni kansuru zassho toji, 1942. Title 1464.

Naimushō. Chihōkyoku. shinkōka. Burakukai, chōnaikai nado seibi ni kansuru shorui, 1940-1942. Title 1463.

—. Keihōkyoku. bōhanka. Sōsenkyo kankei kiroku, 1937. Title 1453.

- hōanka. Senkyo enzetsukai genron torishimari hyojun nara-

bini genron no sekkyokuteki shidō yōryō sōfu no ken, March 24, 1942. Title 1504.

-. - - Shūgiingiin Andō Masazumi teishutsu seifu no 
senkyo taisaku ni kansuru shitsumon shuisho ni taisuru tōbensho sōfu no ken, March 23, 1942. Title 1503.

- . Yokusan sōnendan ni taisuru sayoku bunshi no sennyü soshi ni kansuru ken, February 10, 1942. Title 1500.

Title 15.04.

- . jōhōka. Dai 21 kai shügïn giin sōsenkyo ni okeru Tokyō kakushobetsu undō jōsei shiryō, April 1942. Title 1467. 1451.
—. - - Shochō kaigi kankei shorui, 1937-1944. Title 1454. senkyo kankeisho toji, 1937 . Title 1455.

jōsei töi February- Shōwa 17 nen 4 gatsu shikō shūgiin gïn sōsenkyo jōsei toji, February-May 1942. Title 1469.

shügiin gïn sōsenkyo kankei Naimushō tsuchō töì, January-lune 1942. Title 1470.

1942. Title 1468 . . Shügiin giin sōsenkyo (jumbi kikan) shorui toji, 1. . . seijikakari. Shōwa 17 nen 4 gatsu 30 nichi shikō shügïn giin sōsenkyo ni okeru senkyo kanshō mondai, August 1942. Title 1472. 1527.

Mutō Akira. "Mutō Akira nikki." (At Bōeichō senshishitsu).

Shōwa 17-nen 4-gatsu shūgiin senkyo kōhō Tokyo-fu. 3 vols. (At Tokyo shisei chōsa shōzō).

Shōwa 17-nen 4-gatsu 30-nichi shikō shügiin giin senkyo Tōkyō-fu kōhosha bunsho (shiryō). 13 vols. (At Tōkyō shisei chōsa shōzō).

Published Documents and Parliamentary Records, Japanese Language

Imai Seiichi and Itō Takashi, eds. Gendaishi shiryō. v. 44 Kokka sōdōin, 2. Misuzu shobō, 1974.

Kakagawa Tomiko, ed. Gendaishi shiryō. v. 42 Shisō tōsei. Misuzu shobō, 1976.

Kōan chōsa chō, ed. Senzen ni okeru uyokudan no jōkyō (shiryō). 4 vols. Naikaku insatsu kyoku, 1964-1967.

Naigai Chōsa Shiryō, eds. "Dai 21 kai shūgiin sōsenkyo narabini kore o meguro saikin no seiji jōsei ni kansuru shiryō," Naigai Chōsa shiryō, 14:6 (August 1942).

Naimushō. keihōkyoku, ed. Shōwa jüshichinen chu ni okeru shakai undō no jōkyō (Secret). rpt. San-ichi shobō, 1972.

‥ hōanka, ed. Tokkō geppō (Top Secret). January 1936 through December 1943. rpt. Kenbun shoin, 1973.

Odagiri Hideo and Fukuoka Ikichi, eds. Shōwa shoseki/shimbun/zasshi hakkin nenpō. 4 vols. Meiji bunken, 1967.

Shihōshō hōshukyoku, ed. Shisō geppō (Top Secret) \#92-96 (March-July 1942). rpt. Bunsei shoin, 1974.

Shūgiin jimukyoku, eds. Dai 21 kai shügiin sōsenkyo ichiran. Naikaku insatsu kyoku, 1943.

Taisei yokusankai, ed. Dai san kai chūō kyōryoku kaigi sōjōkai kaigiroku (Secret) September 26-29, 1942. Taisei yokusankai, 1942. 
Rinji chūō kyōryoku kaigi kaigiroku (Secret) February 25-26, 1942. Taisei yokusankai, 1942.

Takahashi Masae, ed. Gendaishi shiryō. vols. 4, 5, 23. Kokkashugi undō, 1, 2, 3. Misuzu shobō, 1964-1974.

Teikoku gikai kizokuin giji sokkiroku, dai $77-79$ (1941-1942); dai 80-81 kai (1942-1943). Naikaku insatsukyoku, 1942-1943.

Teikoku gikai kizokuin iinkai kaigiroku (1941-1942). Naikaku insatsukyoku, 1942.

Teikoku gikai shügiin giji sokkiroku, dai 77-79 kai (1941-1942); dai 80-81 kai (1942-1943). Naikaku insatsukyoku, 1942-1943.

Teikoku gikai shūgiin iinkai kaigiroku, dai 77-78 kai (1941); dai 79-kai (1942); dai 81 kai (1943). Naikaku insatsukyoku, 1942-1943.

Yokusan seijikai, ed. Yokusan seijikai no kessei made ni. Yokusan seijikai, 1942.

- Yokusan seijikai kaïn meibo. Yokusan seijikai, 1942.

- Jüyō kokusaku ni kansuru shiryō II. Yokusan seijikai, 1943.

Yokusan seiji taisei kyōgikai, ed. Yokusan seiji taisei kyōgikai kiroku (Secret). Yokusan seiji taisei kyogikai, 1942.

Periodicals, Pamphlets, and Newspapers, Japanese Language

Denki shimbun. June-July 1976.

Höchi shimbun. January-June 1942.

Kokumin shimbun. January-June 1942.

Miyako shimbun. January-June 1942.

Naikaku jōhōbu. Shūhō. 1940-1942.

Naimu kōsei jihō. January-August, 1942.

Osaka Asahi shimbun. January-June 1942.

Shōwa kenkyūkai jimukyoku, ed. Seiji kikō kaishin taik̄ō. Shōwa kenkyukai jimukyoku, 1940.

Tokyo Asahi shimbun. October 1941-December 1943.

Tokyo Nichi Nichi shimbun. January-June 1942.

Yokusan seiji taisei kyōgikai, ed. Senkyo undō kokoroe. Yokusan seiji taisei kyōgikai, 1942.

- Yokusan seiji taisei kyōgikai no shimei. Yokusan seiji taisei kyogikai, 1942.

Yokusan sōnendan honbu, ed. Dai Nippon yokusan sōnendan no soshiki oyobi katsudō (Yokusan sōnendan shiryō dai $6 \mathrm{gō}$ ). Yokusan sōnendan honbu, 1942.

Yomiuri shimbun. January-June 1942.

INTERVIEWS

Akao Bin: March 4, 1977.

Fujiwara Takeo: February 22, 1977.

Furui Yoshimi: February 19, 1977.

Imamaki Yoshio: February 15, 1977.

Hashimoto Seinosuke: September 21, 1976.

Hazama Shigeru: March 1, 1977.

Miyake Shoichi: March 25, 1977.

Murata Gōrō: February 14, 1977.

Rōyama Masamichi: January 29, 1977. 
Tsukui Tatsuo: Correspondence, September 16, 1976 and October 12, 1976.

Yokoyama Jōsei: July 1, 1976.

Books, Japanese Language (All publishers in Tokyo)

Akimoto Ritsuo. Sensō to minshū: Taiheiyō sensōka no toshi seikatsu. Gakuyō shobō, 1974.

Andō Masazumi. Kōwa o mae ni shite. Keizai ōrai sha, 1951.

Arahara Bokusui, ed. Daiuyokushi. Shubunsha, n.d.

Aritake Shuji. Maeda Yonezō den. Maeda Yonezō den kankōkai, 1960.

Asahi shimbunsha, ed. Shōwa jūhachinen Asahi nenkan. Asahi shimbunsha, 1942.

- Shōwa jūkunen Asahi nenkan. Asahi shimbunsha, 1943.

- Shōwa jürokunen Asahi nenkan. Asahi shimbunsha, 1940.

- Shōwa jūshichinen Asahi nenkan. Asahi shimbunsha, 1941.

—. Shöwashi no shùnkan. 2 vols. Asahi shimbunsha, 1974.

- Yokusan senkyo taikan. Asahi shimbunsha, 1942.

Bōeichō bōei kenshūsho senshi shitsu, eds. Daihon'ei rikugunbu: Daitōa sensō kaisen keii. vols. 1 and 2. Asagumo shimbunsha, 1973.

. Dai hon'ei rikugunbu (3) Shöwa 17 nen 4 gatsu made ni. Asagumo shimbunsha, 1970.

Dōmei tsushinsha, ed. Shōwa jühachinen Dōmei jïi nenkan. Dōmei tsuchinsha, 1942.

—. Shōwa jūkunen Dōmei jïi nenkan. Dōmei tsushinsha, 1943.

- Shōwa jūshichinen Dōmei jiji nenkan. Dōmei tsushinsha, 1941.

Endō Tatsuo. Endō Tatsuo ik̄oshu. Endō Tatsuo ikōshu kankōkai, 1975?

Fujita Yoshimitsu. Yokusan senkyo tokuhon. Shin kigensha, 1942.

Fujiwara Akira. Gunjishi. Tōyō keizai shinposha, 1961.

- Nihon minshū no rekishi vol. 9 Sensō to minshū. Sanseidō, 1975.

-., Imai Seiichi, and Tōyama Shigeki. Shōwa shi. rev. ed. Iwanami shoten, 1959.

-., Imai Seiichi, and Ōe Shinobu, ed. Kindai Nihonshi no kisō chishiki. Yuhikaku, 1972.

Fukai Eigo. Sūmitsuin jūyō giji oboegaki. Iwanami shoten, 1967.

Furui Yoshimi. Senkyo hōki. Nihon hyōronsha, 1936.

Furui Yoshimi-shi danwa sokkiroku. Naiseishi kenkyū shiryō, unnumbered. Naiseishi kenkyūkai, no date.

Gikai shimbunsha, ed. Yokusan gikai meikan. Gikai shimbunsha, 1942.

Gotō Fumio-shi danwa dai 5-kai sokkiroku. Naiseishi kenkyū shiryō dai-9-shū. Naiseishi kenkyūkai, 1963.

Gotō Ryūnosuke-shi danwa sokkiroku. Naiseishi kenkyū shirō dai-66, 67, 68, 69-shu. Naiseishi kenkyūkai, 1968.

Harada Kumao. Saionjikōo to seikyoku. 9 vols. Iwanami shoten, 1950-1956.

Hasegawa Masayasu. Shōwa kempō shi. Iwanami shoten, 1961.

Hashimoto Seinosuke-shi danwa sokkiroku. Naiseishi kenkyū shiryō dai 23-shū.

Naiseishi kenkyūkai, 1964.

Hata Ikuhiko. Gun fuashizumu undōshi. Kawade shobō, 1972 ed.

Hatanaka Shigeo. Shōwa shüppan danatsu koshi. Tosho shimbunsha, 1965.

Hatoyama Ichirō. Hatoyama Ichirō kaikoroku. Bungei shunju, 1957. 1952.

Hattori Takushirō. Daitōa sensō zenshi. 8 vols. Masu shobō, 1955-1956. 
Hayashi Shigeru. Nihon no rekishi. Vol. 25. Taiheiyō sensō. Chūō kōron sha, 1967.

Hazama Shigeru-shi danwa sokkiroku. Naiseishi kenkyū shiryō dai-31, 32, 33shū. Naiseishi kenkyūkai, 1965-1966.

Hoshino Naoki. Jidai to jibun. Daiyamondo sha, 1968.

Hosokawa Morisada. Jōhō tennō ni tassezu. 2 vols. Isobe shobō, 1953.

Inomata Keitarō. Nakano Seigō. Yoshikawa kobunkan, 1960.

Irogawa Daikichi. Aru Shōwashi. Chūō kōron sha, 1975.

Ishida Takeshi. Nihon kindaishi taikei vol. 8. Hakyoku to heiwa 1941-1952. Tokyo daigaku shuppankai, 1968.

Itō Takashi. Nihon no rekishi vol. 30. Jügonen sensō. Shogakkan, 1976.

-, ed. Kegaritsugu Shōwashi. 4 vols. Asahi shimbunsha, 1975-1976.

Iwanami shoten henshubu, ed. Iwanami köza Nihon no rekishi vol. 20 and 21. Kindai 7, 8. Iwanami shoten, 1976-1977.

Japan. Kokkai shūgiin-sangiin, eds. Gikai seidō 70-nen shi. 12 vols. Okura insatsu kyoku, 1960-1963.

Jinji kōshin roku. Jinji kōshinsho, ed. vol. 13 (1942) and vol. 28 (1975).

Kido Kōichi. Kido Köichi nikki. 2 vols. Tokyo daigaku shuppankai, 1966.

Kiyosawa Kiyoshi. Ankoku nikki. Tōyō keizai shinpōsha, 1954.

Kobayashi Gōrō. Tokkō keisatsu hiroku. Seikatsu shinsha, 1952.

Kojima Noboru. Taiheiyō sensō. 2 vols. Chūkō shinsho, 1965-1966.

Kōmei senkyo renmei, ed. Shügiin senkyo no jisseki dai 1 kaidai 30 kai. Komei senkyo renmei, 1967.

Kyoto daigaku bungakubu kokushi kenkyūshitsu, ed. Nihon kindaishi jiten. Tōyō keizai shimbunsha, 1966.

Mainichi Shimbunsha, ed. Shōwa jukunen Mainichi nenkan. Mainichi Shimbun, 1943.

Matsushita Yoshio. Nihon kokubō no higeki. Fūyū shobō, 1967.

Mikuni Ichirō, ed. Shōwashi tanpō vol. 4. Taiheiyō sensō kōkìi. Bancho shobō, 1974.

Miyake Shoichi. Ikusanaga o koete. Kobunsha, 1966.

Mutō Akira. Hitō kara Sugamo e. Jitsugyō no Nihonsha, 1952.

Nagai Kafū. Kafū zensh $\bar{u}$ vol. 23. Iwanami shoten, 1963.

Nagata Tetsuzan kankōkai, ed. Hiroku Nagata Tetsuzan. Fūyū shobō, 1972.

Naikaku jōhōkyoku, ed. Daitōa sensō ni kansuru kokusaku no sūkō. Okurashō insatsu kyoku, 1942.

Naikaku kanbō, ed., Naikaku seidō nanajūnenshi. Okurashō insatsu kyoku, 1955.

Nakamura Kikuo. Shōwa seijishi. Keiō tsushin, 1958.

-. Tennōsei fuashizumu ron. Hara shobō, 1967.

Nakano Yasuo. Seijika Nakano Seigō. 2 vols. Shinko kaku shoten, 1971.

Nakatani Takeyo. Senji gikaishi. Minzoku to seijisha, 1974.

Nihon jyānarisuto renmei, ed., Genron danatsu shi. Ginko shobō, 1949.

Nihon kindai shiryō kenkyūkai, eds. Nihon riku-kaigun no seidō, soshiki, jinji. Tokyo daigaku shuppankai, 1971.

Nihon kokumin undō kenkyūjō (Shimizu Shin), ed. Nihon kokumin undō nenshi. Kenbun shoin, 1943.

Nihon seiji gakkai, ed. Nenpō seijigaku, 1972: "Konoe shintaisei" no kenkyū. Iwanami shoten, 1973.

Nihon seiji kenkyūshitsu hensan (Tsukui Tatsuo), ed. Shōwa jühachinendō Nippon seiji nenpō (dai 1 gō). Shōwa kankōkai, 1943. 
Shōwa jūhachinendōka kihan Nippon seiji nenpō (dai 3 gō). Shōwa kankōkai, 1943.

Nikan rōdō tsushinsha, ed. Uyoku undō yōran. Nikan rōdō tsushinsha, 1964.

Noyori Hideuchi. Sensō to senkyo. Shubunkaku shobō, 1942.

Osaka Mainichi shimbunsha and Tokyo Nichi Nichi shimbunsha, eds. Shōwa jühachinen Mainichi nenkan. Nichi Nichi shimbunsha, 1942.

Otani Keijirō. Shōwa kempeishi. Misuzu shobō, 1966.

Ozaki Yukio. Minken tōsō nanajūnen. Yomiuri shimbunsha, 1952.

—_. Ozaki Gakudō zensh̄u. vol. 9. Kōronsha, 1955.

Rekishigaku kenkyūkai, eds. Taiheiyō sensō. 6 vols. Aoki shoten, 1972.

Saitō Takao. Kaikoron nanajünen. Minsei shoin, 1948.

Sanseidō henshūbū, ed. Konsaisu jinmei jiten (Nihon-bu). Sanseidō, 1976.

Satō Kenryō. Taiheiyō sensō kaikoroku. Tokkan shobō, 1966.

- Satō Kenryō no shogen. Fūyū shobō, 1976.

Sekiguchi Tai. Fusen kōza. Asahi shimbunsha, 1927.

Shakai mondai kenkyūkai, ed. Uyoku jiten: Minzoku-ha no zembō. Futabata sha, 1970.

- Uyoku: Minzoku-ha jiten. Kokusho kankōkai, 1976.

Shimizu Shin, ed. Nippon kokumin undo no kihon mondai. Kenbun shoin, 1943.

Shiraki Masayuki. Nihon seitōshi (Shōwa hen). Chūō kōron, 1949.

Soma Masao. Nihon senkyo keihatsushi. Akaruku tadashii senkyo suishin zenkoku kyōgikai, 1972.

Suda Teiichi. Kazami Akira to sono jidai. Misuzu shobō, 1965.

Sugiyama Gen. Sugiyama mèmo. 2 vols. Hara shobō, 1967.

Taikakai, ed. Naimushō shi. 4 vols. Chihō zaimu kyokai, 1971.

Tōjō Hideki kankōkai, ed. Tōjō Hideki. Fūyū shobō, 1974.

Tōkyō jūni channeru hōdōbu, ed. Shogen Watakushi no Shōwashi vol. 3. Taiheiyō sensō zenki. Gakugei shorin, 1969.

Tomita Kenji. Haisen Nippon ni uchigawa-Konoe kō no omoide. Kokon shoin, 1962.

Toyama Shigeru and Adachi Yoshiki, comps. Kindai Nihon seijishi hikkei. Iwanami shoten, 1961.

Tōyō keizai shinpōsha, ed. Daitōa senka no jikyoku to seikaku no dōkō. Tōyō keizai shinpōsha shuppanbu, 1942.

Tsukui Tatsuo-shi danwa sokkiroku. Nihon kindai shiryō sōsho B-6. Nihon kindai shiryō kenkyūkai, 1974.

Tsukui Tatsuo, ed. Shōwa jüshichinen Nippon seiji nenpō dai 1-gō. Shōwa shobo, 1942.

Tsurumi Shunsuke, ed. Nihon no hyakunen vol. 3. Hateshinaki sensen. Tsukuma shobō, 1962.

Uchikawa Yoshimi, ed. Dokyūmento Shōwashi vol. 3. Nitchū sensō. Heibonsha, 1975.

Ugaki Kazunari. Ugaki Kazunari nikki. 3 vols. Misuzu shobō, 1971.

Wagatsuma Sakae, ed. Nihon seiji hanketsu shiroku (Shōwa-go). Dai ichi hoki shuppan kabushiki kaisha, 1970.

Watanabe Tsutsui, et al., ed. Nihon kempōshi. Tokyo daigaku shuppankai, 1976.

Yabe Teiji. Konoe Fumimaro. 2 vols. Kōbundō, 1952.

Yabe Teiji nikki kankōkai, ed. Yabe Teiji nikki: ichō no kan. Yomiuri shimbunsha, 1974. 
Yatsugi Kazuo. Shōwa dōran shishi. 3 vols. Keizai ōraisha, 1971-1973.

Yokusan undōshi kankōkai, ed. Yokusan kokumin undōshi. Yokusan undōshi kankōkai, 1954.

Articles, Japanese Language

Akazawa Keijitsu. "Sōsenkyo to seitō soshiki." Gendai (April 1942), 181-187.

Amaya Kikuo. "Yokusan sōnendan ni kansuru konpon mondai." Nippon Hyöron, 17:3 (March 1942), 114-119.

Arai Tatsuo. "Sōsenkyo o kaerimite." Ekonomisuto, 20:18 (May 13, 1941), 16-18.

Arima Ikuma. "Bunkajin to yokusan senkyo." Nippon Hyōron, 17:5 (May 1942), 60-62.

"Aru hanketsu no kiroku." Hōgaku semina, 41 (August 1959), 55-61.

Awaya Kentarō. "1936, 37 nen sōsenkyo ni tsuite." Nihonshi kenkyū, 146 (October 1974), 107-124.

Chihōkyoku shinkōka. "Kaku dōfūken ni okeru yokusan senkyo kantetsu undō no seika, 1." Shimin, 37:7 (July 1942), 34-43; 37:8 (August 1942), 27-35.

"Daitōa sensō kansui yokusan senkyo kantetsu undō ni kansuru tsūchō." Shimin, 37:3 (March 1942), 58-78.

Dewa Ichirō. "Daitōa senka no senkyo o kaerimite." Chihō gyōsei, 50:6 (June 1942), 15-20.

Fujita Yoshimitsu. "Konji sōsenkyo no gō tokucho." Shūkan Asahi (May 3, 1942), 16-17.

Hashimoto Kingòrō. "Chikara wa hito da." Kaizō, 24:6 (June 1942), 63-67.

Honda Gensho. "Makoto no daihyōsha." Chūō kōoron, 656 (April 1942), 178180.

Honryō Shinjirō. "Seinen rensei no gutaiteki hōsaku." Kaizō, 24:6 (June 1942), 57-59.

Hozumi Shichirō. "Sōsenkyo to kokumin undō." Nippon Hyōron, 17:3 (March 1942), 120-123.

-. "Sōsenkyo e no kitai." Kaizō, 24:4 (April 1942), 180-188.

Ichikawa Kiyotoshi. "Sōsenkyo to seisōnen." Chūō kōron, 656 (April, 1942), 20-28.

Ideuchi Yoshio. "Senkyohō no kashakujo yori mitaru yokusan senkyo." Hōritsu jishin, 14:4 (April 1942), 62-65.

Imai Hisashi. "Keimō undō to senkyo undō." Shimin, 37:3 (March 1942), 34-36.

Imai Seiichi. "Ōko shita rokotsu no kanshō." Asahi jyānaru, 7:44 (October 24, 1965), 78-85.

Imamatsu Jirō. "Torishimari no tachiba yori kantaru sōsenkyo." Shimin, 37:3 (March 1942), 27-33.

Inomata Keitarō. "Aru yokusan senkyo no kiroku." Nihon rekishi, 163 (January 1962), 78-83.

Inoue Sozaburō. "Yokusan senkyo o tsuku, 1." Ekonomisuto, 20:14 (April 15, 1942), 38-39. 36-37.

Irie Tanenori. "Konpon rinen o ikketsu seyo," Kaizō, 23:3 (February, 1941), 103-104.

Ishii Kin'ichirō. "Nihon fuashizumu to chihō seidō." Rekishigaku kenkyū, 307 (December 1965), 1-12. 
Itō Takashi. "Shōwa seijishi kenkyū e no isshi kaku." Shisō, 624 (June 1976), 215-228.

Iwabuchi Tatsuo. "Seijiteki shinnin ron.” Kaizō, 24:5 (May 1942), 164-167.

Izawa Hiroshi. "Daigishi tekikakusei no kōsatsu." Bungei shunjū, 20:4 (April 1942), 48-53.

“Jikyoku kensetsu mondō." Kōron (May 1942), 172-183.

"Jikyoku mēmo-Yokudō no shinseiji kessha soshikian." Kokusaku kenkyükai shūhō, 1:9 Part 1 (March 1942), 6-7.

"Jimu taidan-Yokusan gikai kenritsu no tame ni." Bungei shunjū, 20:4 (April 1942), 70-82.

Kada Tetsuji. "Bunkajin to senkyo." Nippon Hyōron, 17:5 (May 1942), 54-59.

Kan Tarō. "Naze no senkyo de aru ka." Kōron (April 1942), 41-53.

Kawada Hidenao. "Yokusan senkyo no shomondai." Nippon Hyoron, 17:5 (May 1942), 146-149.

Kawamura Yukai. "Suisen seidō ron." Kaizō, 24:4 (April 1942), 32-43.

- "Dai 21 kai sōsenkyo no seiseki to senkyohō kaisei no shomondai." Höritsu jishin, 14:6 (June 1942), 38-41.

Kiyose Ichirō. "Seiji taisei no sasshin o nozomu." Kokusaku kenkyūkai shūhō, 4:19 Part 2 (May 1942), 1-3.

Kobayashi Masayuki. "Nihon hanyudayashugi no genryū to Mitsukawa Kentaro, 1.” Kaigai jijo, 21:11 (November 1973), 1-9; 22:2 (February 1974), $61-72$.

Kodaira Kenichi. "Nōgyō mondai e no isshi kaku." Kaizō, 24:6 (June 1942), 59-61.

Kondō Masao. “'Kempei seiji' to Nakano Seigō jiken.” Gunji kenkyū, 8:4 (March 1973), 99-107.

Konishi Risaburō. "Sōsenkyo to senkyo shukusei." Chihō gyōsei, 50:4, 15-20.

Kuroda Manabu. "Yokusan senkyo to kokumin ronri." Chūō kōron, 656 (April 1942), 1-12.

Kuroda Iwao. "Kyokoku shintaisei to yokusan senkyo." Gendai (April 1942), 176-180.

Maki Tatsuo. "Watakushi to shintaisei undō; gun no kitai to genmetsu." Rekishi to jimbutsu, 32 (April 1974), 44-47.

Maruyama Kanji. "Yokusan gikai no honshitsu." Ekonomisuto, 20:10 (March 11, 1942), 9-11.

Matsuo Kikutarō. "Yokusan senkyo to suisen seidō." Hōso kōron, 14:4 \#416 (April 1942), 13-17.

Mitsui Sakakichi. "Kannagara seiji no kensetsu." Kaizō, 24:6 (June 1942), 61-63.

Mizoguchi Isao. "Sōsenkyo no jōken." Chūō kōron, 656 (April 1942), 13-19.

Morinaga Eizaburō. "Ozaki Yukio fukei jiken-shidan saiban dai sanshu 28." Högaku semina, 196 (April 1973), 122-124.

Murakami Hyoe. "Shōwa 16 nen 12 gatsu yōka, sono hi . . .." Gendai no $m e, 8: 12$ (December 1967), 160-171.

Murobuse Takanobu. "Jihyō: tsugi no sōsenkyo." Nippon Hyōron, 17:3 (March 1942), 10-13.

- "Kokumin undō no hatten." Nippon Hyōron, 17:3 (March 1942), $13-16$. $11-13$.

"Sōsenkyo o mae ni shite." Nippon Hyōron, 17:5 (May 1942), 5-8. 
Muruyama Sei. "Senkyo mēmo." Shükan Asahi (May 17, 1942), 12-13.

Nagano Akira. "Sōsenkyo to kokunai kakushin." Kaizō, 24:4 (April 1942), 95-101.

Nagano Yoshitatsu. "Daitōa sensō to yokusan senkyo." Shimin, 37:3 (March 1942), 37-46.

Nakamura Misanji. "Yokusan senkyo to kokumin no sekinin.” Bungei shunjū, 20:4 (April 1942), 60-69.

Narita Ichirō. "Daitōa sensō kansui yokusan senkyo kantetsu undō kihon hōsaku." Shimin, 37:3 (March 1942), 7-10.

Ōgushi Toyō. "Bunka to seiji no mondai." Chūō kōron, 658 (June 1942), 74-77.

Okamoto Shigeru. "Daitōa sensō kansui yokusan senkyo kantetsu undō konpon yōkō kaisetsu." Shimin, 37:3 (March 1942), 11-18.

Ōnishi Kunitoshi. "Yokusan gikai no senkyo seidō ron." Nippon Hyōron, 16:1 (January 1941), 7-22.

- "Kōhosha suisen seidō." Waseda seiji keizai gaku zasshi, 83 (August, 1942), 61-80.

Ōno Takeo. "Kibō no nōson." Kaizō, $24: 5$ (May 1942), 183-195.

Ōshima Masanori. "Yokusan senkyo no jūyōsei." Ekonomisuto, 20:15 (April 22, 1942), 9-11.

Rōyama Masamichi. "Kuru beki sōsenkyo no ishiki." Kaizō, 24:4 (April 1942), 26-31.

—. "Kaku tatakai kaku omou." Chūō kōron, 658 (June 1942), 78-82.

Saitō Noboru. "Sōsenkyo jimu no shikō ni tsuite." Shimin, 37:3 (March 1942), 19-26.

Saitō Ryū. "Hitori kokumin toshite no kimochi." Chūō kōoron, 656 (April 1942), 180-183.

Sakagami Nobuo. "Yokusan senkyo to Ozaki Yukio," Sekai to gikai, 55 (January 1966), 29-32; 56 (February 1966), 30-34; 57 (March 1966), 21-25; 58 (April 1966), 28-32; 59 (May 1966), 29-33.

Sanbō honbu sensō shidōhan, ed. "Daihon'ei kimitsu sensō nikki, 1." Rekishi to jimbutsu, 1 (September 1971), 333-373; 2 (October 1971), 279-309; 3 (November 1971), 280-309.

Sasaki Soichi. "Taisei yokusankai to kempō no ronten." Kaizō, 23:3 (February 1941), 8-48.

- "Giin kōhosha sentei ni okeru kokuminsei," Kōhō zasshi, 8:3 (March 1942), 73-78.

"Senkyo ato no seiji dōkō o hanaseru." Kokusaku kenkyūkai shūhō, 4:19 Part 2 (May 1942), 4-11.

“Senkyo ni kansuru tsūchō gyōsei kanrei." Chihō gyōsei, 50:6 (June 1942), 21-33.

Shinmei Masamichi. "Yokusan senkyo ni nozomu." Ekonomisuto, 20:12 (March 25, 1942), 9-11.

- "Yokusan senkyo no seijiteki seikaku." Kaizō, 24:4 (April 1942), 19-25. $1-10$.

“Shinsenkyo no sōzō.” Nippon Hyōron, 17:4 (April 1942), 72-91.

"Shūgiin giin sōsenkyo no kekka." Toshi mondai, 34:6 (June 1942), 127-131.

"Sōsenkyo to watakushi." Shūkan Asahi (April 20, 1942), 7-10.

Sugimoto Moriyoshi. "Tokkō keisatsu no soshiki to unyō, 1." Jiyurisuto, 14 (July 15, 1952), 19-25; 15 (August 1, 1952), 39-43, 33. 
Tabata Iwako. "Yokusan seiji taisei no jiban toshite no kokumin soshiki." Chūo kōron, 656 (April 1942), 29-38.

Taira Teizō. "Chihō toshi no teiryū." Kaizō, 24:5 (May 1942), 174-182.

Takahashi Nobushi. "Sōsenkyo no seijiteki tokusei." Ekonomisuto, 20:14 (April 15, 1942), 40.

Tazawa Yoshiharu. "Sōsenkyo ni saishite zenkokumin ni omou." Shimin, 37:3 (March 1942), 47-54.

Tozawa Tetsuhiko. "Konkai no senkyo to shōrai no gikai." Chūō kōron, 656 (April 1942), 39-44.

“Tsugi no sōsenkyo ni ikanaru hito o erabu ka." Nippon Hyōron, 17:3 (March 1942), 155-160.

Tsukui Tatsuo. "Sōsenkyo o mae ni shite." Nippon Hyōron, 17:3 (March 1942), 155-160.

-. "Kuhai no benjiru." Chūō kōron, 658 (June 1942), 82-85.

Yabe Teiji. "Konoe shintaisei no nazo." Chisei (December 1956), 266-275.

Yamada Hyō. "Nihonteki gikai no sōken.." Kōron (April 1942), 189-194.

Yamamura Kan’ichi. "Gikai shinnin ron." Chūō kōron, 658 (June 1942), 73-77.

Yokogoshi Eiichi. "Mutō jidai no seijiryoku gaku, 1." Nagoya daigaku hōsei ronshü, 32 (September 1965), 1-50; 33 (December 1965), 35-93.

"Yokusan gikai kakuritsu no tame ni." Bungei shunjū, 20:4 (April 1942), 70-82.

"Yokusan senkyo kantetsu undō ni kansuru shiryō." Shimin, 37:3 (March 1942), $55-78$.

"Yokusan senkyo ni sekkyoku sei o." Ekonomisuto, 20:14 (April 15, 1942), 8.

"Yokusan senkyo no seika bunseki." Ekonomisuto, 20:18 (May 13, 1942), 31-33.

"Yokusan senkyo to seiji ronri." Chūō kōron, 656 (April 1942), 1-3.

Yoshida Hisashi. "Dorama ni natta watakushi no 'saiban.'” Hōgaku semina, 41 (August 1959), 63.

Yoshikawa Kanemitsu. "Daitōa sensōka sōsenkyo no ishiki." Gendai (April 1942), 169-175.

Yoshikawa Suejirō. "Iwayuru 'Yokusan senkyo' to sono hihan," Toshi mondai, 34:2 (February 1942), 59-68; 34:3 (March 1942), 29-37.

Yoshimuru Tadashi. "Minshushugiteki senkyoken no haisuru-yokusan senkyo no seijiteki ishiki." Kōron (April 1942), 54-58.

- "Senkyo no tōshi to seiryoku no tōshi." Chūō kōron, 657 (May 1942), 80-84.

- "Yokusan senkyo no takushitsu to shinnin no ishiki." Nippon Hyōron, 17:5 (May 1942), 63-68.

Yoshizawa Isejirō. "Yokusan senkyo undō to suisensei." Kokusaku kenkyükai shühō, 1:9 Part 1 (March 1942), 1-5.

Yuge Shichirō. "Giin kōhosha no suisen seidō." Toshi mondai, 34:3 (March 1942), 1-16.

Unpublished documents, English Language

International Military Tribunal for the Far East. Record of the Proceedings, Documents, Exhibits, Judgement, Dissenting Judgements, Preliminary Interrogations, Miscellaneous Documents (Mimeographed). Tokyo, 1946-1949. Particularly:

Registry Group 331. Supreme Commander Allied Powers. International Prosecution Section. Case \#153. Abe Nobuyuki. Exhibit 21. "Interrogation Report of Hashimoto Seinosuke." June 11, 1946. 
Shioden Nobutaka."

Case \#180. Shioden Nobutaka. "Interrogation of Case \#358. The Imperial Rule Assistance Association. Exhibit 17. "Interrogation of Ashida Hitoshi." March 20, 1947.

Office of Strategic Services. Research and Analysis Branch. Research and Analysis Report Number 1939. Japanese Administration: National Government. May 1, 1944.

- . Research and Analysis Report Number 1956. Public Safety in Japan. July 13, 1944.

United States Army. Far East Command. Intelligence. Civil Intelligence Section. "The Brocade Banner: The Story of Japanese Nationalism." Special Report. Mimeographed, 1946.

Unpublished materials, English Language

Berger, Gordon M. "The Search for a New Political Order: Konoe Fumimaro, the Political Parties, and Japanese Politics in the Early Shōwa Era." Ph.D. dissertation, Yale University, 1972.

Norman, E. H. "Politics." n.d., n.p.

Newspapers, English Language

The Japan Times and Advertiser. January-June 1942.

\section{Books, Western Languages}

Akita, George. Foundations of Constitutional Government in Modern Japan, 1868-1890. Cambridge: Harvard U. Press, 1967.

Beasley, W. G., ed. Modern Japan: Aspects of History, Literature, and Society. Tokyo: Charles E. Tuttle Co., ed., 1976.

Bergamini, David. Japan's Imperial Conspiracy. New York: William Morrow and Co., Inc., 1971.

Berger, Gordon M. Parties Out of Power in Japan, 1931-1941. Princeton: Princeton U. Press. 1977.

Borg, Dorthy, and Okamoto Shumpei, eds. Pearl Harbor as History: Japanese American Relations, 1931-1941. New York and London: Columbia U. Press, 1973.

Borton, Hugh. Japan Since 1931: Its Political and Social Developments. rpt. of 1940 I.P.R. Inquiry Series. Greenwood Press, 1973.

Browne, Courtney. Tojo: The Last Banzai. New York: Paperback Library Edition, 1968).

Butow; Robert J. C. Tojo and the Coming of the War. Stanford: Stanford U. Press, 1961.

Cohen, Jerome B. The Japanese War Economy, 1937-1945. Minneapolis: U. of Minnesota Press, 1949.

Craig, Albert M., and Donald H. Shively, eds. Personality in Japanese History. Berkeley and Los Angeles: U. of California Press, 1970.

Crowley, James B., ed. Modern East Asia: Essays in Interpretation. New York: Harcourt, Brace, and World, 1970.

Dull, Paul S. and Michael Takaaki Umemura. The Tokyo Trials: A Functional Index to the Proceedings of the International Military Tribunal for the Far East. Center for Japanese Studies, Occasional Papers \#6. Ann Arbor; Center for Japanese Studies, 1962. 
Friedrich, Carl J., and Zbigniew K. Brezezinski. Totalitarian Dictatorship and Autocracy. Cambridge: Harvard U. Press, 1956.

Guillain, Robert. Le Peuple Japonais et la Guerre, Choses vues 1939-1946. Paris: Rene Julliard, 1947.

Jansen, Marius B., ed. Changing Japanese Attitudes toward Modernization. Princeton: Princeton U. Press, 1965.

Johnson, Chalmers. An Instance of Treason. Stanford: Stanford U. Press, 1964. Johnston, Bruce F. Japanese Food Management in World War II. Stanford: Stanford U. Press, 1953.

Kato, Masuo. The Lost War: A Japanese Reporter's Inside Story. New York: Alfred A. Knopf, 1946.

Krausnick, H., ed. Anatomy of the SS State. London: Collins \& Sons, Ltd., 1968.

Maruyama Masao. Thought and Behaviour in Modern Japanese Politics. London: Oxford U. Press, 1963.

Mason, R. H. P. Japan's First General Election 1890. London: Cambridge U. Press, 1969.

Maxon, Yale Candee. Control of Japanese Foreign Policy: A Study of Civil Military Rivalry, 1930-1945. University of California Publications in Political Science, Number 5. Berkeley and Los Angeles: U. of California Press, 1957.

Mitchell, Richard H. Thought Control in Prewar Japan. Ithaca: Cornell University Press, 1976.

Morley, James W., ed. Dilemmas of Growth in Prewar Japan. Princeton: Princeton U. Press, 1971.

Morris, John. Traveller from Tokyo. New York: Sheridan House, 1944.

Najita, Tatsuo. Hara Kei in the Politics of Compromise, 1905-1915. Cambridge: Harvard U. Press, 1967.

Peattie, Mark R. Ishiwara Kanji and Japan's Confrontation with the West. Princeton: Princeton U. Press, 1975.

Reischauer, Edwin O. Japan: Past and Present. 3rd ed., rev. New York: Alfred A. Knopf, 1964.

Scalapino, Robert. Democracy and the Party Movement in Prewar Japan. Berkeley and Los Angeles: U. of California Press, 1953.

Schiffrin, Harold Z., ed. Military and State in Modern Asia. Jerusalem: Jerusalem Academic Press, 1976.

Shillony, Ben-Ami. Revolt in Japan. Princeton: Princeton U. Press, 1973.

Smethurst, Richard J. A Social Basis for Prewar Japanese Militarism: The Army and the Rural Community. Berkeley and Los Angeles: U. of California Press, 1974.

Steiner, Kurt. Local Government in Japan. Stanford: Stanford U. Press, 1965.

Supreme Commander Allied Powers. Government Section. Political Reorientation of Japan: September 1945 to September 1948. 2 vols. Washington: U.S. Government Printing Office, 1949.

Titus, David A. Palace and Politics in Prewar Japan. New York: Columbia U. Press, 1974.

Toland, John. The Rising Sun: The Decline and Fall of the Japanese Empire 1936-1945. New York: Random House, 1970.

Totten, George O. The Social Democratic Movement in Prewar Japan. New Haven: Yale U. Press, 1966.

Unger, Aryeh L. The Totalitarian Party: Party v. People in Nazi Germany and Soviet Russia. London: Cambridge U. Press, 1968. 
Ward, Robert E., ed. Political Development in Modern Japan. Princeton: Princeton U. Press, 1968.

- Japan's Political System. Englewood Cliffs: Prentice Hall, 1967.

Wilson, George M., ed. Crisis Politics in Prewar Japan: Institutional and Ideological Problems of the 1930s. Tokyo: Sophia U. Press, 1970.

Young, John. Checklist of Microfilm Reproductions of Selection Archives of the Japanese Army, Navy, and Other Government Agencies, 1868-1945. Washington: Georgetown U. Press, 1959.

Articles, English Language

Fujii Shinichi. "The Cabinet, the Diet, and the Taisei Yokusan Kai." Contemporary Japan, 10:4 (April 1941), 487-497.

Furusawa Isojiro. “The Wartime Non-Party Diet." Contemporary Japan, 10:4 (April 1941), 461-476.

_. “Japan's Wartime General Election." Contemporary Japan, 11:5 (May 1942).

Havens, Thomas R. H. "Women and War in Japan, 1937-45." The American Historical Review, 80:4 (October 1975), 913-934.

lizawa Shoji. "Diet Members Unite." Contemporary Japan, 10:10 (October 1941), 1261-1269.

Keene, Donald. "Japanese Writers and the Greater East Asia War." Journal of Asian Studies, 23 (1963/1964), 209-225.

Nagashima Matao. "Reorganization of the Cabinet and Taisei Yokusan kai." Contemporary Japan, 10:5 (May 1941), 768-777.

Shinobu Seizaburō. "From Party Politics to Military Dictatorship." The Developing Economies, 5:4 (December 1967), 666-684.

Steven, R. P. G. "Hybrid Constitutionalism in Prewar Japan." The Journal of Japanese Studies, 3:1 (Winter 1977), 99-133.

Wilson, George M. "A New Look at the Problems of 'Japanese Fascism.", Comparative Studies in Society and History, 10:4 (July 1968), 401-412. 



\section{Index}

Abe Nobuyuki, 25, 28, 30, 31-2, 63-4, $70-71,77,81,87,89,90,101,107$, $135,139,140,170$ n. 12,182 n. 19 , 183 n. 34

Adachi Kenzō, 76

Adults Association. See Greater Japan Yokusan Young Adults Association Akamatsu Katsumaro, 11, 22, 74

Akao Bin, 19, 41-2, 69, 73, 81-2, 95, $115,140,143,147,149-150$

Akinaga Tsukizō, 7, 9

Akita Kiyoshi, 22, 29, 116, 142

Andō Kisaburō, 20, 28, 38, 40, 64, 102, 151, 173 n. 4

Andō Masazumi, 17, 22, 91, 117, 130, 174 n. 26; Diet interpellation, 65-9

ankoku seiji (police state), 149

anti-Semitism, 106-9, 114, 178 n. 26;

prevalance, 109. See also Shioden Nobutaka

Araki Sadao, 177 n. 2

Arima Yoriyasu, 9, 10, 29, 123

army regimental commanders, 71-2, $114,130,155,163$ n. 29

Asanuma Inejirō, 79

Ashida Hitoshi, 11, 22, 130, 147

Bungei shunjū (magazine), 37, 54, 109

black market, 59

Cabinet Information Bureau, 35, 84, 168 n. 31

Cabinet Information Committee, 54, 168 n. 31

Cabinet Information Department, 54, 168 n. 31

Cabinet Planning Board, 9, 10

Cabinet Planning Board Incident, 9, 10,159 n. 25

Campaign rallies, 61-2, 97, 99-100; police supervision of, 57-8; compared to $1936-1937$ rallies, 99-100; number restricted, 99-100, 176 n. 65

Candidate Recommendation system (1942), 13-14, 70, 74-5; origin, 24-5; adopted by Political Council, 31; criticism of, 33, 63-5; Diet criticism of, 65-9; constitutionality of, 65, 69; defended by Tojo, 66-8; rejected in 81st Diet, 149. See also Recommended Candidates

Central Headquarters for National Spiritual General Mobilization (Kokumin seishin sōdōin chūō honbu), 3

Central League for General Mobilization of the National Spirit (Kokumin seishin sōdöin chūō renmei), 3

Central Restaurant faction (Chūo tei), 11

Chūō kōron (magazine), 54

Chūō kurabu (Central Club), 129

Conference to Establish a Clean Election (Junsei senkyo kisei kyōgikai), 69

Constitution, Meiji, 1, 6, 13, 22, 27, 33, $55,69,92-3,112,128,153,155$

Crime Prevention Department (bōhanka), 45

Dai Nippon seijikai (Greater Japan Political Association), 153

Dai Nippon seisantō (Greater Japan Production Party), 95

Dai Nippon sekiseikai (Greater Japan Sincerity Association), 42, 69, 79, 95, 140, 143

Dai Nippontō (Great Japan Party), 80, 95

Daitōa dōshikai (Greater East Asia Comrades Society), 109

Dōjin kurabu (Comrades Club), 18

Dōkōkai (Fraternity Association), 17, 18, 22, 33, 48, 59, 65, 69, 73-5, 79, $89,91-4,104,112-3,117,130-31$, $136-40,143,147,149-50,171$ n. 28 , 174 n. 26

Doolittle Air Raid (April 1942), 98-9, 133

election bond, 80, 82, 126, 172 n. 56; table of confiscations (1942), 127

election brokers, 49, 111

election first philosophy controversy, 63-4

Elections (Japan): attempts at reform, $12-13,160$ n. 38 ;

of $1890,1,45,54$ 
of $1892,45,128-9,132$

of $1915,128-9,132$

of $1928,54,88,128-30,132$

of $1936,58-9,69,100$

of $1937,58-9,100$

of 1942, iv-v, 21-7, 35-6, 56, 61, 103, 138-9; air raid, 98-9; as didactic election, 27, 60, 63, 82-3, 91; as show election, 51, 53, 58-9, 91, 94, 125; assessment, 154-5; cabinet resolution, 22; campaign atmosphere, 83-4, 97-8; censorship, 55-6, 60, 188-192; independent candidates, 91-6; investigations, 46-7; organization, 22-34; overview, 83-102; preliminary planning, 24-5; police efforts to mobilize vote, 34-5; results, 133-9; right-wing candidates, 95-6; selected candidates' campaigns, 103-128; voter coercion, 134-5. See also campaign rallies, candidate recommendation system, election interference, election law violations, enlightenment campaign, Home Ministry, police, recommended candidates, Yohusan Political Structure Cooperative Council

Election interference, 1-2, 45-6, 54, 67, $87,92-3,105-6,111,114-5,118-20$, $122,124,125-32,148-9,151,155$; alleged in Gumma, 105-6; in Kagoshima, 125-7, 151; in Tokushima, 118-9; perspective, 129-32; problem of identification, 111, 120; recurrent problem, 92, 94; table, 131

election law violations, 46-7, 49-50, 52, 111,120

Emperor Meiji, 6, 92

Enlightenment Campaign (keimō undō), 26-7, 34, 37, 40, 83, 85, 138; Adults Association, 87; IRAA, 84-6

Endō Ryusaku, 28, 30, 170 n. 18

Etō Genkurō, 150

First Lobby (Dai ichi hikaeshitsu), 18, 34,172 n. 48

Fujiwara Ginjirō, 28, 30

Fujiyama Aiichirō, 28, 90, 170 n. 18

Four Companies Council (Yonshakai), 54-5
Fuke Toshiichi, 109, 110

Gendai (magazine), 55

genronsha (opinion makers), 56

Genyōsha (Dark Ocean Society), 8

Gestapo Law (1936), 170 n. 10

Giin kurabu (Diet Members Club, 1940), 10

Giin kurabu (1941), 18, 28, 34, 74, 75, 136,147

Gō Seinosuke, 9

Gōdo Takuo, 28, 30, 90, 170 n. 18

Gotō Fumio, 3, 20, 24-5, 28, 30, 87, $90,102,170$ n. 18,173 n. 4

Gōto Ryūnosuke, 14

governors, 7, 10, 72, 93, 105-6, 129-30, 141; allegations of interference, $114-5,118-20,123,125,128-32$; election instructions (1942), 34-5, 38, 51-2, 57; election role, 1-3; recommend prefectural Political Council members, 14, 24, 31

Greater East Asia War (Daitōa sensō), 40, 66, 80

Greater Japan Yokusan Young Adults Association (Dai Nippon yokusan sōnendan ), 32, 34, 38-40, 42, 59, $64-5,71-3,76,77,83-5,89,98,110$, $138,144-7,149,151-3,155,164-5$ n. 58; alleged interference, 114,117 , 119 , 124-6, 130; enlightenment campaign, 84-7

Hara Sōbei, 11

Haraguchi Hatsutarō, 137

Hashida Kunihiko, 102

Hashimoto Kingorō, 9, 29, 42, 78, 95, 140,143

Hashimoto Seinosuke, 24-5, 88

Hatoyama Ichirō, 4, 10, 17, 22, 73, 74, $94,117,130,137,150,164$ n. 26 , 180 n. 54

Hayashi Senjūrō, 25

Hazama Shigeru, 3, 8, 10, 20

Hirai Hachisaburō, 28, 30, 170 n. 18

Hiranuma Kiichirō, 8-9, 11, 12, 15-6, 108, 159 n. 25

Hisuisen yüshi daigishikai (Unrecommended Candidates Volunteer Diet Men's Association), 149

Home Ministry, 1-3, 6-8, 10, 20, 24-5, $29,35,36,43,83,88,101,128-32$, 134, 154-5; Adults Association pol- 
icy, 38; censorship, 55, 57; Doolittle Raid, 98-9; election intelligence reporting, 53; election related conferences, 50-2; election supervision, 45 50; Instruction, 14, 57; mobilizing vote, 34-6; proscribes Rikken yōseikai, 78; Reservist Association policy, 31-2. See also Elections (Japan), Governor, Police, Police Bureau

Honda Eisaku, 118

Honryō Shinjirō, 114

Hoshino Naoki, 24, 88

Ida Iwakusa, 20, 30, 41, 79, 90, $170 \mathrm{n}$. 18

Ii Seiichi, 124

Ikken kinnō undō (One Prefecture Loyalist Movement), 96, 115, 171 n. 38

Imai Hisashi, 50

Imamaki Yoshio, 176 n. 59

Imamatsu Jirō, 23, 24, 170 n. 12

Imperial Japanese Diet, 10, 23, 63, 65-6, $70,81-82,109,151$;

76th Session, 10, 15, 139

77th Session, 18, 23

78th Session, 20

79th Session, 65

80th Session, 142

81 st Session, 146-50

82nd Session, 150

83rd Session, 151

Imperial Hotel faction, 11

Imperial Rule Assistance Association (Taisei yokusankai), 5-12, 14-16, 18, 20-21, 23, 27, 29, 32-6, 39, 42, $48,64-5,69,71,76,80,89,94,119$, $122,124,134,139-41,144-6,148$, 151-4, 159 n. 22; enlightenment campaign, 83-6; First Extraordinary Central Cooperative Committee Conference (1940), 14-5; Second Extraordinary Central Cooperative Committee Conference, 36-8

Independent candidates, 80-2, 88, 89, 91-6, 172 n. 55; selected campaigns, 116-127

Ino Hiroya, 76

Instruction 14, 57-60, 98, 100, 107, 109, 114; translated Appendix D, 189-92

Intelligence Section (jōhōka), 45, 48, 49
Inukai Takeru, 182 n. 24

invalidated ballots, 133

Irokawa Daikichi, 109

Ishigurō Tadaatsu, 20, 30

ishin (restoration), 42, 95

Ishiwara Kanji, 42, 95, 138

Iwabuchi Tatsuo, 63

Iwai Police Station, 53

Iwaguro Hideo, 7

Iwamura Michiyo, 52, 102, 113

Japan Publishers Cultural Association (Nippon shuppan bunka), 55

jiban, 2, 14, 23, 27, 32, 37, 40, 49, 63-5, $73,75,81,85-6,88,91,94,100-101$, $104,109,111-3,115,117,120,123-6$, $128,135-6,145,149,153,157$ n. 2

Jikishin dōjō (Sincerity School), 95

Jüichinichikai (Eleventh Day Society), 147

Jiyūtō (Liberal Party), 129

kaban (campaign funds), 110, 111-2

Kaizō (magazine), 54

Kamei Kan'ichirō, 11

kanban (political reputation), 111-2

Katō Kanjū, 177 n. 12

Katsu Masanori, 28, 71, 74, 141-2

Kasumata Seiichi, 159 n. 25

Kawai Eijirō, 104, 177 n. 2

Kawamata Seion, 124, 130

Kawamura Saburō, 7

Kawasaki Katsu, 10, 11, 17, 22

Kaya Okonori, 102

Kazami Akira, 76, 171 n. 38

Keibōdan (Coastal Defense units), 93, $114,122,130$

Keizai giin renmei (Economic Representatives League), 148

Kenkokukai (National Founding Society), 41-2, 60, 69, 80, 115, 140, 143

Kidō Koichi, 13, 25, 68, 182 n. 19

Kikuchi Kan, 37

Kinnō makoto musubisha (Association of True Loyalists), 69, 151

Kishi Nobusuke, 76

Kita Reikichi, 130

Kiyose Ichirō, 14, 137, 148

Kōa giinkai (Asia Development Diet Members Association), 17-18, 34, 74, 118, 136-7

Kobayashi Jun'ichirō, 8

Kodama Hideo, 28, 30 
Kodama Yoshio, 111

Kōdō yokusan seinen renmei (Imperial Way Assistance Youth League), 41-2, 69, 95, 115

Kogure Sanjirō, 104-05

$k \bar{o} h \bar{o}$ (official statement of candidacy), $61,87,91$

Koiso Kuniaki, 28, 30, 153, 170 n. 18

Kokuhonsha (National Foundation Society), 28

Kokumin giyütai (People's Heroic Fighting Corps), 153, 185 n. 68

Kokumin domei (Nationalist League), 4, 14

Kokumin kyoiku shinkō gïn renmei (Dietman's League to Promote Public Instruction), 147

Kokuryūkai (Amur River Society), 8

Kokusaku kantetsu domei (League to Accomplish National Policy), 17

Kokusai hankyō renmei (International Anti-Communist League), 79

Kokusaku kenkyūkai, 28, 29

Kokusui taishütō (National Essence Mass Party), 41, 80, 95

kokutai (national essence), 8-9, 23, 48, 70, 109

Konoe Fumimaro, 5-6, 9, 11, 12-16, 23, 81,159 n. 25

Korean suffrage, 176 n. 69

Kōron (magazine), 55

Kuhara Fusanosuke, 4

Kumagai Ken'ichi, 10

Kumagai Naota, 74

League for the Construction of a Cooperative Order in the Farming Villages (Nōson kyōdōtai kensetsu dömei), 39-40

Machida Chūji, 4, 75, 137, 142, 153

Maeda Yonezō, 4, 7, 14-15, 16, 22, 28, $30,33,71,137,141-2,144-5,148$, 153

Maki Tatsuo, 7

Makino Ryōzō, 11, 106

Manabe Katsu, 117

Maruyama Tsurukichi, 102

Matsuzaka Hiromasa, 52, 151

Maurras, Charles, 109

Metropolitan Police Board, 53, 55, 99, 101-02, 151; evaluation of Diet incumbents, 21-2; instruction on can- didate investigations, 47-8; supervision of rightist rallies, 42

Mikami Takashi, 41, 42

Miki Kumaji, 116-7

Miki Takeo, 103; campaign, 116-8; police interference against, 116-7; tactics, 116-7

Miki Yokochirō, 116

Military Affairs Bureau, 7, 8, 24, 38, $41,51,72,121,124,152,154$; and Adults Association, 38, 41

military police (kempeitai), 45, 46, 58, $59,150,151$

Minseitō, 4, 11, 28, 41, 74, 117, 129-31

Mitamura Takeo, 149, 180 n. 57

Miwa Jyūsō, 48, 79, 177 n. 12

Miyake Shoichi, 99, 103; campaign, 122-4; jiban, 123; tactics, 123-4

Miyake Yujirō, 121

Miyazawa Taneo, 11; and 77th Diet controversy, 18

Miyoshi Shigeo, 7

Mizuho kurabu (Japan Club), 79, 95-6, 108

Murata Gōrō, 72, 104, 105, 106

Mutō Akira, 7, 24-5, 154, 162 n. 16; total war ideas, 7

Nagai Kafu, 19

Nagai Ryūtarō, 4, 22, 25, 28, 30, 33, $71,87-8,90,137,141-2,144,148$

Nakai Yotarō, 102

Nakano Seigō, 5, 9, 29, 33-4, 73, 95-6, 98, 103, 149-51; campaign, 113-6; tactics, 113-6

Nakajima Chikuhei, 4, 16, 22, 61, 121, 137,142

Narita Ichirō, 23, 24, 26, 34, 51

National Governors' Conference, 51-2

National Police Chiefs' Conference, 52

neighborhood associations, 3, 8, 27, $35-6,125-6,134,154$

“new men," 27, 37, 48, 77-8, 91, 103-06, $117,123-7,137,143$; composite, 76-7; definition, 23; elected, table, 135; motivations, 81-2; numbers of, 80; recommended, 73-4. See also independent candidates \& recommended candidates

New Party Movement: 1940, 3-5, 7, $10 ; 1941,16-7,23 ; 1942,25$ 
Nihon musantō (Japan Proletariat Party), 4, 5, 59

Nippon hyōron, 54

Nishioka Takejirō, 103; campaign, 118-20; legal appeals, 119

Nomura Karoku, 137

Noyori Hideuchi, 103; campaign, 120-2; criticism of election, 121-2, 139; interference problems, 122; tactics, 121

Ōasa Tadao, 22, 28, 32-3，71，73-4, $141-2,144,151$

Oda Shigeru, 114

Ogura Masatsune, 28, 30

Oikawa Koshirō, 15

Ōishi Dai, 114

Okabe Nagakage, 151

Okada Tadahiko, 22, 28, 30, 33, 71

Ōkochi Kikō, 65, 67-8, 148

Ōkochi Masatoshi, 28, 29, 30

Okumura Kiwao, 102

Ōkuma Shigenobu, 129

Ömori Kota, 102

Ōta Kōzō, 28, 30, 41, 79, 90, 170 n. 18

Ōta Masataka, 28, 30, 34, 71, 74, 90, $141-2$

Ōura Kanetake, 129

Outline for Guiding Public Opinion (Genron shidō yōryō), 60-61

Outline of the Basic Campaign for the Accomplishment of the Yokusan Election (Yokusan senkyo kantetsu kihon yōko), 26; translation Appendix A, 187-8

Ozaki Yukio, iv, 10-11, 17, 22, 91-2, $94,98,103,117,127,137,147,180$ n. 54,182 n. 24 ; arrest of, 112 ; campaign, 112-3; legal appeal, 113; lése majestè affair, 93; open letter to Tojo, 69

Pak Ch'un-Kum, 100-01

Patriotic Associations Council for General Election Measures (Sösenkyo taisaku aikoku dantai kyōgikai), 41

Pearl Harbor; effect on censorship policy, 55; effect on homefront Japan, 19-21. See also World War II Japan Homefront

Police, 34-6, 47-50, 52, 55-6, 120; Adults Association, 39-40; alleged election interference, 92-4, 105-6, 114-7,
125-6, 128-32; cautions \& suspensions issued, 100, 107; censorship, 55; Instruction, 14, $57 \mathrm{ff}$; investigations of candidates, 49-50; post election political assessment, 142-3; supervision of campaign speeches, $52-3,110,115$; supervision of rightists, 42. Also see Home Ministry, Metropolitan Police Board

Police Bureau (keihōkyoku), 45, 48-50, 52, 55; Adults Association, 39; Control of campaign rallies, 57-8; Instruction, 14, 57

Political Affairs Investigatory Committee, 141

Political Council, see Yokusan Political Structure Cooperative Council

Political Parties, 2, 4, 13, 14; decline of, 2-3; dissolution of, 5, 18. See also Dōkōkai, Kokumin dōmei, Minesitō, Nihon musantō, Rikken dōshikai, Seiyūkai, Shakai taishūtō, Tōhōkai, Yokusan seiji kai

Political Parties' leaders, 27, 34, 37, 63; assessment by police, 21-2; dominate Yokusan Political Association, 141; Political Council members, 32-3; re-assert authority in Diet, 16-8; resilience, 152 ; role in Political Council recommendations, 71, 74-6; suitable as recommended candidates, 22; victors in 1942 election, 137

Prefectural Police Affairs Section Chiefs' Conference, 50, 51

Prefectural Promotion Branch Conference, 51

Press control, 54-5; Appendix B, 188. See also censorship

Public Security Police Law (chian keisatsuhō), 11-12, 27, 78, 140, 154

recommended candidates, 60-1, 70-7, 87-9; criticism of, 76-7; "new men" among, 87-8; selection of, 71, 171 n. 32. See also candidate recommendation system

Reservist Association (Teikoku zaigō gunjinkai) , 7, 21, 31, 34, 38, 71, 72, $108,117,126,130,134,139,164-5$ n. 58

Right Wing (Reform faction), 8-9, 
40-3, 59-60, 64-5, 69-70, 78, 81, 94, $96,115,151$; definition, 8; denounces government after air raid, 99; election results, 137-8; post-election attitude, 142-3

Right Wing (Traditional faction), 8, 59-60, 78-9, 95, 137-8; definition, 8; election attitude, 8

Rikken döshikai (Constitutional Comrades Society), 129

Rikken yosseikai (Society for the Cultivation of Constitutional Justice), $42,78-9,81,89,96,115,138$

Rōyama Masamichi, 103-06; election campaign, 103-06; tactics, 105

Saitō Makoto, 157 n. 5

Saito Takaō, 80, 117, 130, 147, 180 n. 54

Saki Tadamasa, 29, 30

Sanjūnichikai (Thirtieth Club), 147, 148

Sansui sakura gumi (Cherry Landscape Society), 147

Sasagawa Ryōichi, 41, 95, 143, 147, 148

Sasaki Itsuchō, 95, 147

Satō Kenryō, 24, 25, 38, 40, 42-3, 70, $152,154,162$ n. 16

Satsuma Yūji, 148, 149

secret police (kōtō keisatsu), 45, 165-6 n. 2

Seishin kurabu (New Diet Members Club), 147, 148

Seiyūkai, 4, 11, 17, 28, 41, 54, 74, 88, $118,120,129-31,142$

Sengoku Kōtarō, 29, 30, 170 n. 18

Senryoku zōkyō rinji kyōgikai (Extraordinary Committee to Reinforce War Potential), 146

Shakai taishutō (Socialist Masses Party), 4-5, 10-11, 17-18, 22, 48, 59, 75, $79,123-4,132$, 149; election results, 137

Shiba Teikichi, 177 n. 12

Shikata Ryōji, 150-1

Shimada Toshio, 16, 137, 153

Shimomura Hiroshi, 29, 30, 170 n. 18

Shimomura Jirō, 103; campaign of, 125-7; interference against, 125-7; legal appeals, 127

Shinagawa Yajirō, 54, 128-9

Shiratori Toshio, 78, 121, 150
Shisaikai (Like Thinkers Society), 147

shortages, 53, 59-60, 100

Shioden Nobutaka, 79, 103, 111, 147, 178 n. 18; anti-Semitism, 106-08; campaign of, 106-09; tactics, 108

Shöwa kenkyükai, 9, 14, 29, 104

Shühō (magazine), 35, 101

Six Companies Council (Rokushakai), 55

sōnendan (adults clubs), 38

sōshi (political bullies), 122

special higher police (tokkō) (thought police), 45, 55, 93, 124, 151, $169 \mathrm{n}$. 25

Suetsugu Nobumasa, 9, 28, 30, 41, 87, 170 n. 18

Susugida Yoshitomo, 151, 152

Suzuki Kantarō, 54, 185 n. 68

Suzuki Kisaburō, 129-30

Suzuki Teiichi, 68

Tagawa Daikichirō, 93, 112-3, 137

Takahashi Sankichi, 28, 170 n. 18

Takami Yukimichi, 74

Takemoto Kuramae Police Station, 49. 50

Taki Masao, 29, 30, 90, 170 n. 18

Tanaka Sawaji, 78, 95, 115

Tanaka Tokichi, 29, 90, 170 n. 18

Tani Masayuki, 102

Tawara Magoichi, 137

Tazawa Yoshiharu, 3, 24, 25, 102

tenkō (conversion), 9, 41

Tōa renmei dōshikai (East Asia Comrades Association), 42, 95, 138

Tōhōdöshikai, 150, 151

Tōhōkai, 4, 5, 33-4, 69, 73, 74, 79, 80-1, $95-6,124,131,136,138,140,143$, 148, 171 n. 28; opposes government policies, 59-60, 114-5; tactics, 113

Tojo cabinet and government, v, 21, $26,27,32,40,54,55,58,63-6,70$, 78, 81-3, 89, 91-2, 96, 99, 101-02, $104,112,115,121,131,135,144$, $146,149,152$. See also Tojo dictatorship and Tojo Hideki

Tojo dictatorship, v, 103, 152

Tojo Hideki, v, 15, 17, 18, 20, 32, 37, $43,51,62,80-1,91,94,101,121-2$, $124,133,135-6,139-40,148-51,153$; criticism of, $112,115,121-2,124$; Diet interpellations, 65-9, 148-9; 
reasons for calling election, 21-3, 25-8, 32, 37

Tokutomi Sōhō, 29, 30

Tomeoka Yukio, 23, 36, 52

tonari-gumi, see neighborhood associations

Tsugumo Kunitoshi, 11, 149, 150

Tsukui Tatsuo, 97, 103, 178 n. 27; campaign of, 109-12; reasons for defeat, 111-2

Tōyama Mitsuru, 108, 121

Uchida Nobuya, 142

Wakamiya Sadō, 137

Wartime Penal Regulations Code, 14950

World War Two; and censorship, 54-5, 98, 100; and election, 61-2; Homefront Japan, 19-21, 84, 145; and rumors, 60. See also Appendix B, 188

Yabe Teiji, 87

Yabuki Seizō, 28, 30

Yagi Itsurō, 74

Yamazaki Iwao, 101, 102, 170 n. 12

Yamazaki Tatsunosuke, 4, 22, 25, 28, $32,33,71,90,137,141-2,144,148$, 151

Yanegawa Heisuke, 9, 20

Yokoyama Sukenari, 20, 25, 28, $170 \mathrm{n}$. 18

Yokudō, see Yokusan giin dōmei

Yokusan Diet, 28, 31, 35, 41, 53, 66, 70, 134, 139; definition, 23

Yokusan election, 37, 51, 87, 101; in Nagasaki (1941), 118, 180 n. 57
Yokusan giin dōmei (Yokudō) (Yokusan Dietmen's League), 17-18, 25, $28,31-3,71,73-4,75,76,78,91$, 116, 140-1, 154, 172 n. 48; election results, 135-7; post election criticism, 138

Yokusan Political Structure Cooperative Council (Yokusan seiji taisei kyōgikai) (Political Council), 2734, 37-41, 48, 53, 55, 58-61, 63-82, 86-9, 94-6, 98-9, 101, 104, 107, 109, $114-5,121,122,125,135,136-8$; criticism of, 63-9, 73, 74, 77-9, 94-6, 114-5; election results, 135; organization, 27-32; personnel, 28-9, 31-2

Yokusan seijikai (Yokusan Political Society), 139-48, 151-4; rightist criticism, 142-3; 81st Diet problems, 147-8

Yokusan seiji kesshū jumbikai (Preliminary Committee for the Concentration of Yokusan Politics), 139

Yoshida Shigeru, 90

Yūki Toyotarō, 28, 30

Yüshi daigishikai (Volunteer Representatives Association), 148

Yuzawa Michio, 20, 22, 24, 25-6, 29, $37,51-2,63,66,68,102,124,148-9$, 170 n. 12

zaibatsu (financial cliques), 8-9, 59, 69, 95, 107, 114, 115

Zenkoku rōnō taishūtō (National Workers \& Farmers Masses Party), 123 





\section{UNIVERSITY OF KANSAS}

\section{Center for East Asian Studies}

\section{International Studies, East Asian Series}

\section{RESEARCH SERIES}

1. Goodman, Grant K.

Davao: A Case Study in Japanese-Philippine Relations. \$4.50

2. Goodman, Grant K., Compiler

The American Occupation of Japan: A Retrospective View. \$2.50

3. Schwarz, Henry G.

Liu Shao-Ch"i and "People's War": A Report on the Creation of Base Areas in 1938 . $\$ 2.50$

4. Wickberg, Edgar, Compiler

Historical Interaction of China and Vietnam: Institutional and Cultural Themes. $\$ 2.50$

5. Akashi, Yoji

The Nanyang Chinese National Salvation Movement, 1937-1941. \$6.00

6. Lie, Chat-Jin

Communist China's Policy Toward Laos: A Case Study, 1954-67. \$5.00

7. Sheng, Yueh

Sun Yat-sen University in Moscow and the Chinese Revolution: A Personal Account. $\$ 8.00$

8. Vlirde, Alfonso

Dialectical Aspects in Buddhist Thought: Studies in Sino-Japanese Mahäyāna Idealism. \$15.00

9. Spear, Richard L.

Diego Collardo's Grammar of the Japanese Language. $\$ 12.50$

10. Asis, Liocadro de

Edited and with an introduction by Grant K. Goodman. From Bataan to Tokyo: Diary of a Filipino Student in Wartime Japan, 1943-44. $\$ 8.00$

11. Drea, Enward John

The 1942 Japanese General Election: Political Mobilization in Wartime Japan. $\$ 8.00$

\section{REFERENCE SERIES}

1. Huang, C. C.

A Modern Chinese-English Dicionary for Students. $\quad \$ 12.50$

2. Lindquist, Harry M., and Meyer, Rogier I)., Compilets

Concordance of Proper Nouns in the Five-Volume English-Language Selected Works of Mao Tse-tung. $\$ 3.00$

Sole distributors in the USA \& Canada

Paragon Book Gallery, Ltd.

$1+$ East 38th Street

New York, N.Y. 10016 
